No. 75 - September 1996

122004

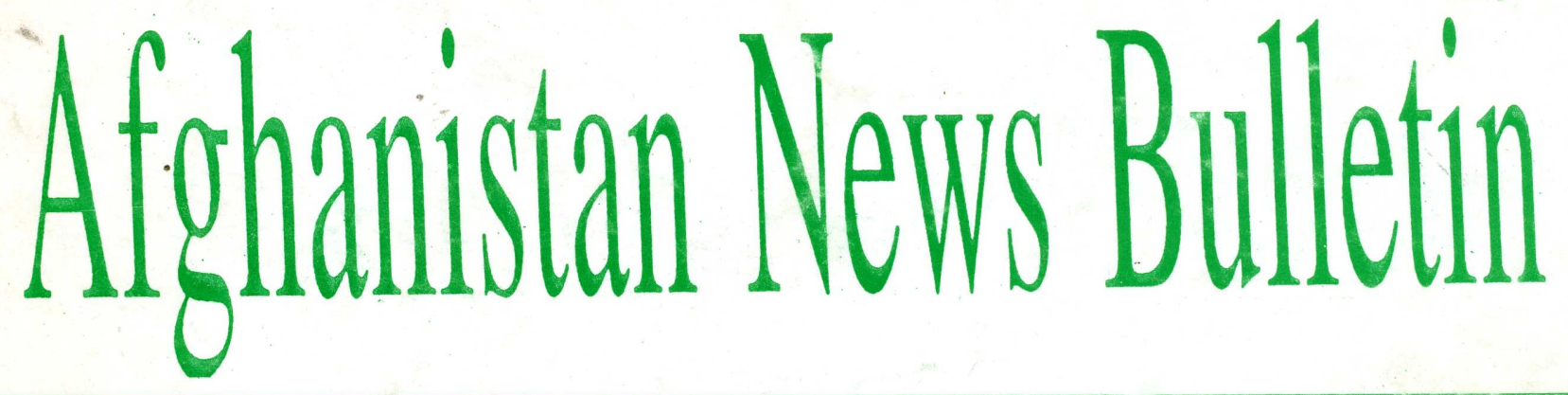

Prepared monthly by Afghanistan News Clipping Services

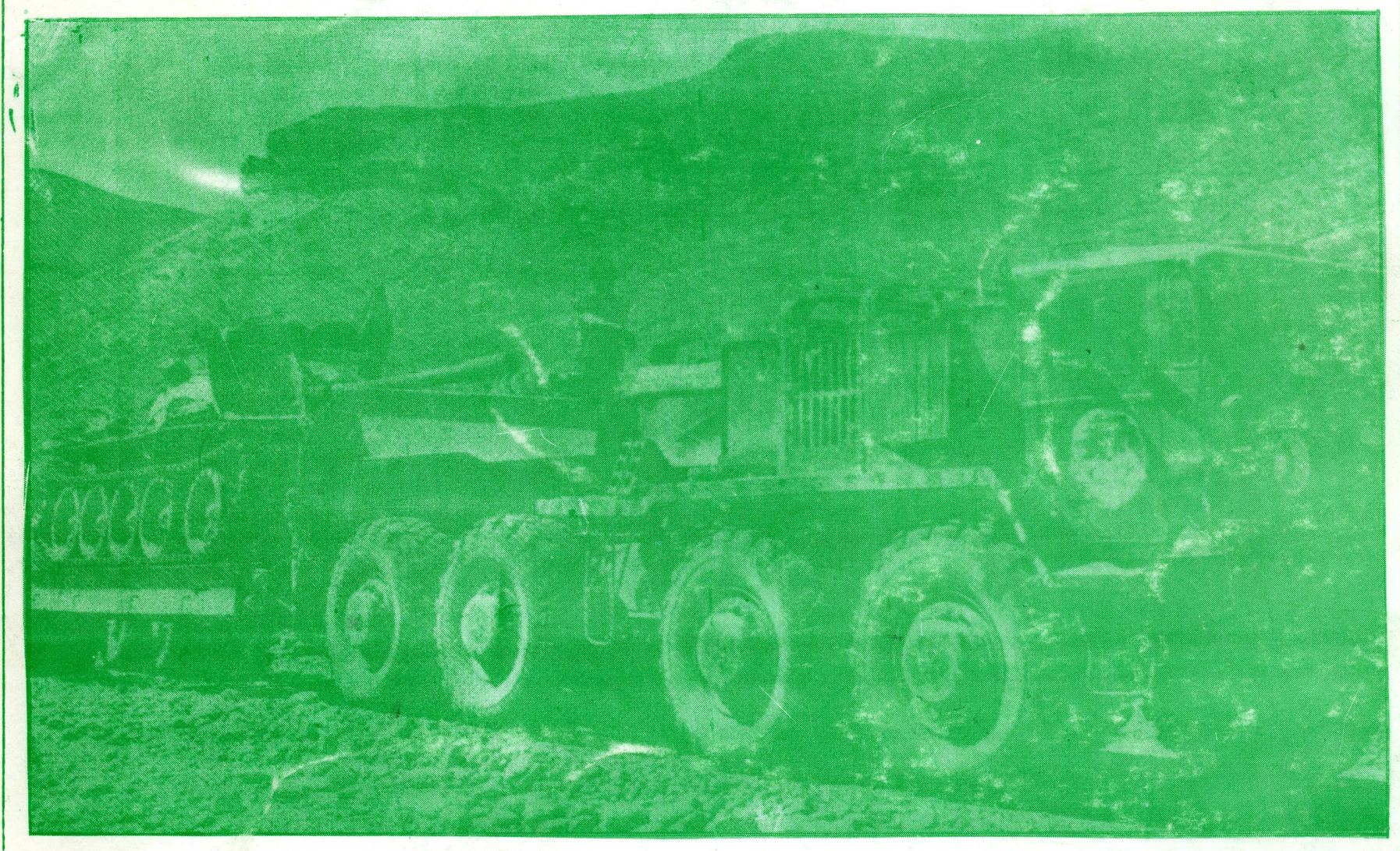

\title{
Taliban:
}

\section{Angels or Agents?}

Price: Pakistan: Rs.400 US\$20 ( 1 broad: US\$35) 


\section{Afghanistan News Bulletin}

No. 75 September 1996

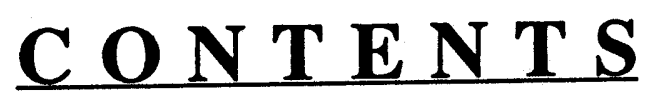

Pages: 146

\section{Afghanistan:}

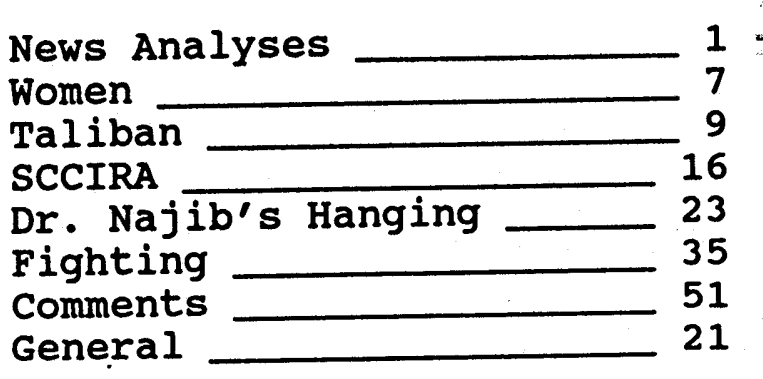

\section{Afghan Govt./ Kabul:}

Political Aspects 72

Peace Initiatives 78

Diplomatic Activities 79

Fighting

General

\section{Refugees:}

Repatriation New Arrivals General

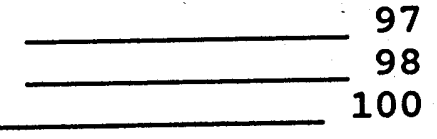

\section{Leaders/ Parties:}

Hekmatyar (HIA)

Hizb-e-Wahdat

General
102 104 105
Foreign Interest:

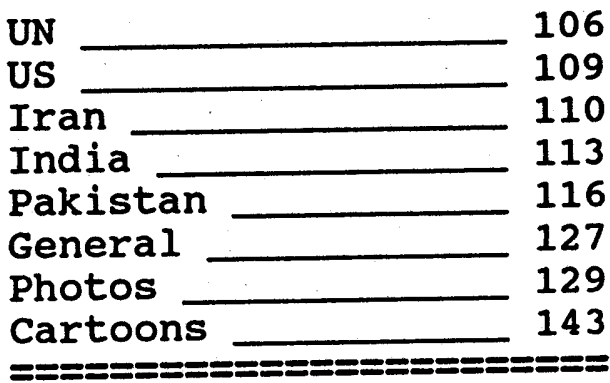

Top Story ----

Taliban: Angels or Agents?

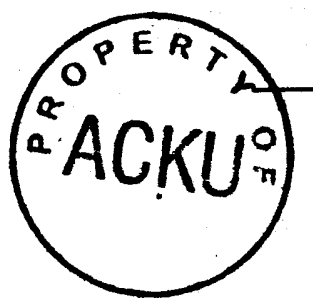

Afghanistan News Bulletin Published monthly by Afghanistan News Clipping Services (ANCS), Peshawar, Pakistan.

Founder: Fawad Ahmad Azizi Compiler: Tawfiq Ahmad Azizi

\section{PRICE}

Pakistan: Pak Rs.400.00 US\$20.00 Abroad: US\$ 30.00 


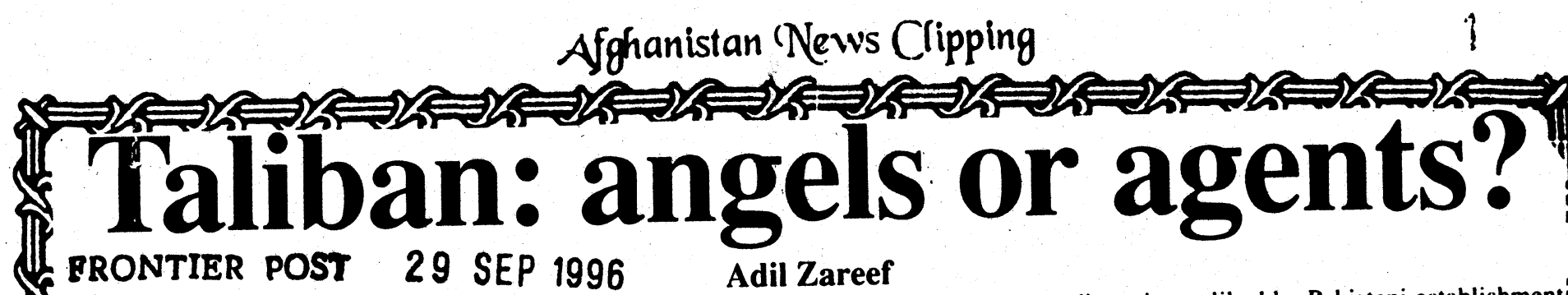

In a lightning stroke, the Taliban overran Kabul on Thursday during midnight. Ever since, the fall of Jalalabad, the demoralised Kabul regime could not put up an effective resistance to the overwhelming power of this mysterious student militia. Soon afterwards, Laghman fell, followed by Kunar. The II unopposed victories amazed their supporters and foes alike. Kabul's fall may be celebrated in some circles. But the first pubLic act of impaling ex-President Najibullah's blood-soaked body along with his brother and bodyguards have shocked many Afghans. Their dexterous viciousness has exposed their inhuman, malevolent barbarism. Afghans are in a polarised state of joy and $\checkmark$ fear. Fear of the unknown. Ever since, the overthrow of Sardar Daud by communists, they have 1 been subjected to the worst kind of fratricide imposed on them by Dower-hungry superpowers. After 1.5 million dead and another five million refugees in Iran and Pakistan they were anticipating freadom and sovereignty to return after the fall of president Najibullah

The LN-brokered cease-fire and transfer of power to an interim government was sabotaged by competing regional countries, eager to exploit Afghanistan's vulnerable position. The mujahideen dictory ensured virtual decimation of Afghan infrastructure and culture. Marauding gangs of religious extremists backed by their foreign-backers, raped, pillaged and scorched whatever they could. Instead of standing stead(I) fast alongside the Afghans, the UUN and the US in their traditional manner left Afghans in the lurch. Another cycle of endless violence and destruction swept Afghanistan. as superpowers reiponsible for the tragic conseyuences turned their gaze to other "profitable enterprises". The Gulf War - for instance.

Tired of senseless bloodshed 11) and misery. Afghans welcomed Uthe emergence of new Taliban Timilitia in November 1994. for delivering them from the blood(ihirsty mujahideen outfits. Al uarring factions stood discredited as warlordism and lawlessness superseded the relative calm that had prevailed in the main Afghan City centres. even during the Theight of the Jehad. Promising Shariat or Islamic Law. the

\section{Adil Zareef}

Taliban achieved swift military victories, owing to restoration of law and order and protection of life and property of common citizens. Political and religious differences apart, the Afghans thanked them for saving them from the barbarism of mujahideen.

Was it a misplaced hope or genuine providence? Rumours mounted about their "origin" and questions were asked about their "motives", but the Taliban remained shrouded in mystery. Maulvi Mohammad Umar, a selfdeclared "Amir ul Momineen" based in Kandahar, pronounced edicts and Sharia laws as his followers enforced strict Islamic punishments like amputations, stoning to death and public hangings as demonstration of pure Islamic injunctions. After a communist experiment, the Afghans were being subjected to another kind of foreign doctrine: strict

the bordering states - disrupting stability and peace.

Until recently, the Taliban had been sounding conciliatory messages to the moderate factions involved in the peace process. An envoy of King Zahir Shah who was in Peshawar recently, expressed his optimism that peace was around the corner. The Taliban high command, according to this source, had expressed its inclination for a UN-sponsored peace accord that may involve Zahir Shah's participation. Apparently, there is a dichotomy in the upper and lower tiers of leadership of this movement. Maulvi Wakil Ahmed sounds conciliatory and pragmatic. But Maulvi Mohammed Rabbani who heads the new six-member interim government in Kabul, is a radical extremist.

The manner Najibullah's coldblooded execution was carried out

The manner Najibullah's cold-blooded execution was carried out within hours of Kabul's fall, speaks volumes for the metamorphosis of the Taliban from honest peace-keepers to blood-thirsty monsters who would spare nobody who could pose a challenge to their monopoly of power. This does raise doubts about the "intentions" of their backers. Najibullah was a dreaded communist but he did restore peace and tranquillity in Afghanistan when mujahideen were doing everything within their means to satisfy the lust of their hidden masters, by destroying their own country.

Sharia. Closing down of schools for females, banning of TV and all sports and recreation activities aroused resentment amongst the Afghans, who have been traditionally observing Muslims but not necessarily obscurants and conservative.

American strategy of playing the religious card against the communist evil reached its climax with the demise of the Soviet Union in Afghanistan. Doesn't the US owe an ounce of gratitude to the Afghans who were destroyed for the sake of "capitalism"? The US learnt, albeit belatedly, the monster they had been nurturing in the form of mujahideen will come to haunt their interests later. Similarly, Pakistan will come to realise that an extremist, obscurant force that has surfaced in Afghanistan will spill over into within hours of Kabul's fall, speaks volumes for the metamorphosis of the Taliban from honest peace-keepers to blood-thirsty monsters who would spare nobody who could pose a challenge to their monopoly of power. This does raise doubts about their backers and their "intentions". Najibullah was a dreaded communist but he did restore peace and tranquillity to Afghanistan when mujahideen were doing everything within their means to satisfy the lust of their hidden masters, by destroying their own country.

One cannot condone Najibullah's strong-arm tactics, but what happened to Afghanistan after his surrender has demonstrated the real motives of the Jehadi parties and their sponsors. He had emerged as a staunch nationalist and was not particularly liked by Pakistani establishment and Americans. Americans generally like pliant and weak puppets who can dance to their tunes. Najibullah unlike his Pakistani counterparts, had stood up against American pressure. He had contributed to the peaceful transfer of power in April 1992. For his services, he was confined to a UN compound in Kabul, while all other former communists and dreaded Khad personal roamed free.

Most shocking is his being car-1 ried out of the UN compound without any resistance. This is a grievous blow to UN's credibility. After Srebenica, where UN personnel willfully surrendered thousands of unarmed civilians to savage Serbs, this latest episode would be marked as another blot on UN's reputation. Afghan mod-? erates who were nurturing hopes about the latest peace initiative have been equally dismayed. The Taliban have become more ambi-? tious and domineering as never, before. Who will control them as they get out-of-reign by the day?

If they can flout the UN today, what's the guarantee they will not? obstruct the UN peace initiative tomorrow? In the present circumstances, Zahir Shah should not trust the Taliban as a "neutral security force" as proposed. Who knows he is next on their bloody list on "someone's" covert instruc-1 tions. Equally alarmed would be Abdur Rashid Dostum, who had tactically supported Taliban's victory by maintaining neutrality in the present conflict. If the Taliban could be so brutal and vindictive why would they spare him? Contrary to their claim of restoring peace and tranquillity in Afghanistan, they seem to settle for nothing less than absolute power. If the Taliban can get so headstrong it could pose serious trouble for the UN peace mission ahead.

The UNSMA director, Francis Okelo has said his office had made a formal request to the Taliban leadership through its security officer to retrieve the bodies of Najibullah and his associates. "He deserves a decent burial" said Okelo. The UN can spare Najibullahs dead body now since it could not save it when it was intact. At the moment, the UNSMA is dead. Both Okelo and the dithering Dr. Norbert Holl need tol take a hike. They have disgraced the UN as never before. It needs a burial with highest honours. The Taliban have dishonoured themselves and their cause by brutalising an unarmed prisoner. 


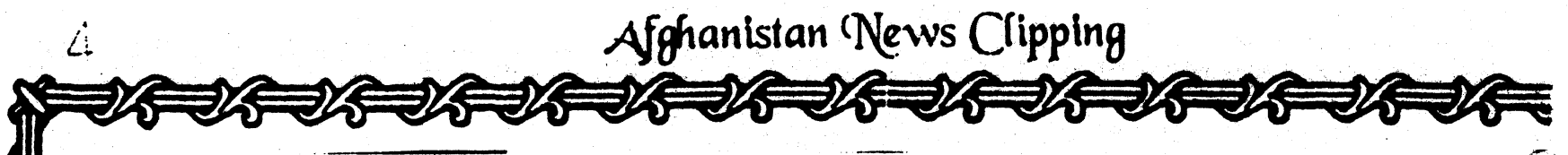

\section{Afghanistan: its social structure and solution}

\section{Dr Azmat Hayat Khan}

The Afghan resistance lgroups that were formed in Peshawar, to fight the Soviets and throw them out of Afghanistan. can be categorised as:

(a) Fundamentalists:

(b) Nationalists; and

(c) Socialists.

The Afghans live in a tribal (egalitarian) society. In Afghan society, Islam is a part of the Pushtu Code, being inseparable from each other, but at limes the Pushto Code hecomes dominant. It has always been traditional national leaders that have led the Afuhans in their hour of crisis.

As tribesmen. the Afghans defend their territory against one another, or against another tribe. In a tribal war, personal and family dispules are forgotten. and every nody gets logether to defend their Iribal territory; during national Frises, tribal differences are resolved and the nation as a whole takes up arms against an invader. or a rebel e.g. When Iran altacked Herial. the uprising against the Moguls, and the Mars with the Khans of Central Asia; against an Cintidel. or a non-Muslim. the trohan urilise national and religirus slogans. e.g. the three Anglo-dighan wars, and the preG viou, Soviet occupation: defending hi religion. country neighbour. customs and traditions be comes a sacred duty for the Af ghan. Defending anything that is sacred to an Afghan, be it religion or the Pushto Code. is a Jihad for an Afghan: religion has becorne at vital. alid inlegral part of the Algitas traditional institutions.

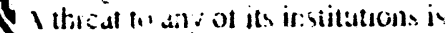
Ccun wers: a iliredi wis islam.

Duc to these reasons. King A::at:iul!ali is!ed ti hi: modemiSalson reir rlis. A jinad has de. Colarcis is. the Khalqis and F'archiarn!, iung liefore the Soviet Ciroons hid entered Afghanistan. Certain reforms which they were imposing on the people. e.g. land retorms. bride moriey, limiting the flumber of guests in a wedding. Encre ali consicieled atyansi islan: If for to an Afghan Pushto code is Islam, and Islam a part of their Pushto code of life. Any ideology which does not fit into their traditional institutions has no meaning for them. Having been born and raised within a certain way of life, giving it up or even changing it is considered a defeat for them and this was the reason that until the Soviets moved in, the rest of the country except the big cities remained untouched and were governed by their own tribal code.

The fundamentalists

They follow an Islamic ideology and want to enter Afghanistan

Pakistan, Iran, Uzbekistan and Russia should get together and work for the solution jointly,

for it serves their interest if Afghanistan is peaceful, united and has an organised government. To control the flow of arms, the borders should be supervised by the UN forces. The UN should raise a force, in which the Taliban, Rashid Dostum, Sayed Jaffer Nadiri of Ismaili sect, and Bashir Khalid, commander of Badakhshan, should be given some representation. Other commanders having a clean record should also be given some responsibility. This force should have the backing and approval of the UN and work under the auspices of an Islamic country, most probably an Arab country, so that it is given an Islamic touch.

with an ideology and install an Islamic state. They follow the principles of the Muslim brotherhood and the Janiat-i-Islami. So for even these groups have failed to unite, and their dispute is more persona! than ideological. There have been miany clashes between the tho large groups in Afghanistan, the Hizb-e-Islami and the Jamiat-e-Islami.

\section{Islamic nationalities}

The leaders of these groups are religious heads, or spiritual leaders. They follow a moderate path. a mixture of religion and national$i$.m. ince in Afghanistan they plus the ones which they had captured from the government troop: In order to get weapons they had approached every party but do not give up allegiance to their own tribe and loyalty to their chief, which to them is a sacred duty and a part of their code of life.

The Socialists and Leftists

Among these forces who are putting up resistance to the Karmal regime, are mostly proPeking. The two big factions among them were the Sitam-eMili and Shola-e-Javaid. They were in favour of a Mao-type peasant revolution in Afghanistan.
But now when they have seen how allergic and hostile the Afghan people are to a foreign ideology, and since Afghanistan is a barren country, with not much of agriculture, the chances of a peasant revolution are nil. These groups have now changed their programme and are not clear in their mind as to what they want now. These two groups have now broken up into splinter groups, some have joined hands with the Mujahideen, while others have fled to Europe.

The Sitam-e-Mili stronghold was in Badakhshan province and mostly among the Tajik people. The Shole-e-Javid had a lot of backing among the Hazaras and Uzbek people. But since their leaders got killed, the Hazaras are now fighting under the spiritual leadership of the Kayan family. With the exception of the two lefiist groups, the Parcham being in power, and the Khalqis in their opposition, all other leftist groups have fled Afghanistan and have either changed their names or have broken up into splinter groups.

Historical events in Afghanistan demonstrate that all national uprisings were led by traditional national leaders, or by tribal or local leaders. During the Ist Afghan war when Amir Dost Mohammad Khan fled to Bukhara, the lack of leadership was quite apparent. Tribal and local figures like Aminullah Khan Logari, Mir Masjid Khan, Osman Khan Tagovi and Mohammad Shah Khan Laghmani led and coordinated jointly the preliminary steps which resulted in the Afghan national uprising. When Warir Akbar Khan appeared, the common leadership bowed before the traditional national leadership who led them to victory.

In the second Afghan war, all local and tribal leaders agreed to the national leadership of Sardar Mohammad Ayub Khan, although there were tribal and local leaders like Mohammad Jan Wardak, Gul

Seo Next Page 

peace and find a solution. then their decision should he honoured becaine the King; during Daud who is responsible for the destrucBacha Khan, Mula Sahib of Hadda and Mula Mushke Alan Although in this uprising Mula Mushhe Alam and Mula Sahib of Hadda were representing the national religious leadership.

In the third Afghan war, the nalional leadership lay with King Amanullah. which was recognised and hacked by all seclions of the Afghan sociely. Tribal chiefs as well as national religious leaders all rallied behind King Amanullah during the national crises.

The present struggle of the Afghan people has failed to find a leader for it lacks a central legal authority, or some one on whom all the tribes can agree. The fundamentalists are well organised and armed. hut they are unpopular among the masses, for political ideology has no place in Afghan society. To them a family comes first, then the tribe, and then religion.

At times of national crises an Afghan gives up his family and tribal differences, to fight for his nation. In the Afghan socicty one is more affiliated io a non-Muslim if his own tribe than to a Muslim of another iribe. $A$ eommunal riot has never been reported in Afghanistan. and at present the Sikhs and the Jews of Kabul city the Ismailis of Badakhshan. the Hacaras of Bamiyan.were all fighting the Soviets to liberate their homeland. hut they are all contined to their own areas and fought under their local leaders. With the absence of the legal central authority from the scene a big vacuum has been created. The tribes have again and again demanded that the royal family be brought back, so that the people can unite and start an organised struggle.

Whenever there is an emergency or a national crisis, the Afghan people call out a Loya Jirga. A normal Loya Jirga consists of elected members from different trihes and constituencies. then there are nominated members. who are tribal chiefs, influential spiritual leaders, intellectuals, rep 1 rescntatives of women and $\mathrm{mi}$ norities, judges of the Supreme Court. cabinet members, elected inembers of Ulusi Jirga and also the King who is the president of ine Jirga. In the absence of the King. a Loya Jirga takes the name of a Momasal Jirga.

In the whole history of Afghanistan. the Loya Jirga has assembled only nine times: by Amir Wais in 1121; by Ahned Shah, when he was proclaimed King of Afghanistan; by King Amanullah. when Afghanistan

Khan's premiersinip and in 1940) Juring World War II; by King Zahir Shah, when he gave Afghanistan the constitution in 1962; during Daud Khan's presidentship in 1974; in Peshawar. Namak Mandi Mosque in 1979: in Quella. during 20-25 Sept 981

The last two which were held in Peshawar and Quetta. are nown as Mamasal Jirga, because the legal central authority was abent and the tribes and provinces ent in their representatives, who were not elected but were nominated by their people. There were epresentatives from all the provinces and each tribe sent in hirty representatives. The nationlists and even members from the fundamentalist groups participat ed, and their aim was to nominate leader, who is popular all over Afghanistan and to unite them in liberating their homeland from the Soviets.

The important decisions that were taken at the Quetta Loya Jirga are: to find a leader who is acceptable to everyone, both as a
national and a religious head; a committee be formed, which would stay within Afghanistan, to control and govern the provinces hat have been liberated from the regime, and the control of all these areas be taken from the different factions and handed over to this committee; a committee be formed to handle the finances of the Afghan refugees, as well as of he mujahideen and to work for the establishment of a national Islamic government

Afghanistan, and no single party be allowed to impose its authority on the Afghan people.

Two very important events have taken place in the history of Afghanistan in the last 20 years: migration of Afghan refugees to Pakistan. Then getting arms, military training and fighting the Soviets and after the Soviet Army withdrawal and with the removal of Dr. Najib-Ullah's government, iill the Mujahideen take over of Kabul, some important political, military and social changes took place.

The persons who were leaders of the Afghan War and were being praised by the leaders of the
Western countries and the free world for putting up a stiff resistance against the Soviets, suddeny became warlords, and the same Afghan nation whom they were eading, stood up against them and wanted liberation from their clutches. Reasons being: that they are not being accepted as leaders by the Afghan nation, because tion of Afghanistan, i.e. the factional leaders, specially Gulbadin and Rabbani and the strength of from the fact that in spite of being hit by both the Soviets and the Mujahideen to destroy it, the present leadership in Afghanistan is ribal e.g. Dostum representing the Turkic speaking people, Masood and Rabbani representing he Tajiks and the Táliban repre enting the Pushtuns.

Social changes

Before the Soviet invasic Malik, a Khan, a Pir, or someone Loya Jirga.

who had served in the government To convene a Loya Jirga is on a high post, whether he knew much more easier now than it was anything or not, was respected. five years back. The fundamental During the war with the Soviets, a factions who were opposing the person who had taken an active Loya Jirga, have lost ground, both part in the war against the Soviet politically and militarily, and have army, or could mobilise a force melted away from the scene. The behind him, was respected.

But presently, only that person Afghanistan i.e. the Taliban, who is cducated. has not commit- General Dostum and Rabbani all led crimes against his own people want a Loya Jirga. Rabbani and and has some programme for the Masood favour a Loya Jirga, for welfare of his people is respected. they know that it operates on strict None of the Afghan factional rules and tribal values are respecteaders or any of the Mujahideen ed.

Commanders fit into this category. A Loya Jirga would give This can be judged from the Rabbani and Masood some face fact that no one could imagine that saving, rather than being overrun Talib could rise against the by the Afghan nation.

Warlords, and the Warlords hav- A Loya Jirga should be sponing all the modern weapons were sored by the UN and it must enjoy eliminated in no time. The main Pakistan's blessings as well. If reason for the Mujahideen's de- Pakistan accepts the convening of feat was that the Taliban wanted Loya Jirga, then Russia and peace and the Mujahideen wanted Uzbekistan would approve it too, war. for it serves their interest. Russia

Solution to the Afghan crisis wants a broad-based government Whichever way the Afghan in Afghanistan, and Uzbekistan problem is solved, whether by the wants an outlet to the sea via neighbouring countries or through Afghanistan and Pakistan, and this the UN, an important point that can only be achieved, if peace in has to be taken into consideration Afghanistan is restored and a stais that Afghanistan remains united ble government is formed.

and as one nation.

The Loya Jirga should be held

There are two main obstacles at on Afghan Soil. either in Herat, or present to the solution of Afghan- in Mazar-i-Sharif.

crisis, they can be termed as inter- External obstacles nal and external.

Internal obstacles

Pakistan, Iran, Uzbekistan and

(a) What has kept the fighting work for the solution jointly for it going on in Afghanistan is the serves their interest if Afghanistan abundance of weapons. It is be- is peaceful, united and has an orcause of these weapons that a few ganised government. To control warlords came into being, and the llow of arms, the borders they along with their gangs plun- should be supervised by the $\mathrm{UN}$ dered the life, property, and hon-forces. The UN should raise a our of innocent Afghans. So the force, in which the Taliban, first step in bringing peace, should Rashid Dostum, Sayed Jatier be the collection of weapons. Nadiri of Ismaili sect, and Bashır (b) To bring peace to Khalid, commander of Afghanistan, and to work for a Badakhshan, should be given proper political solution, more ac- some representation. Other comiive role should be given to tribes manders having a clean record and tribal chiefs, rather than to the should also be given somite respoun Afghan factional leaders that were sibility. This force should have the created in Pakistan, i.e. the seven backing and approval of the $L N$ factions that were formed during and work under the ausjices of an the regime of General Zia. Islaulic country, inusi probably ali (c) Importance should be given Arab cuuntry, so that it is given an 


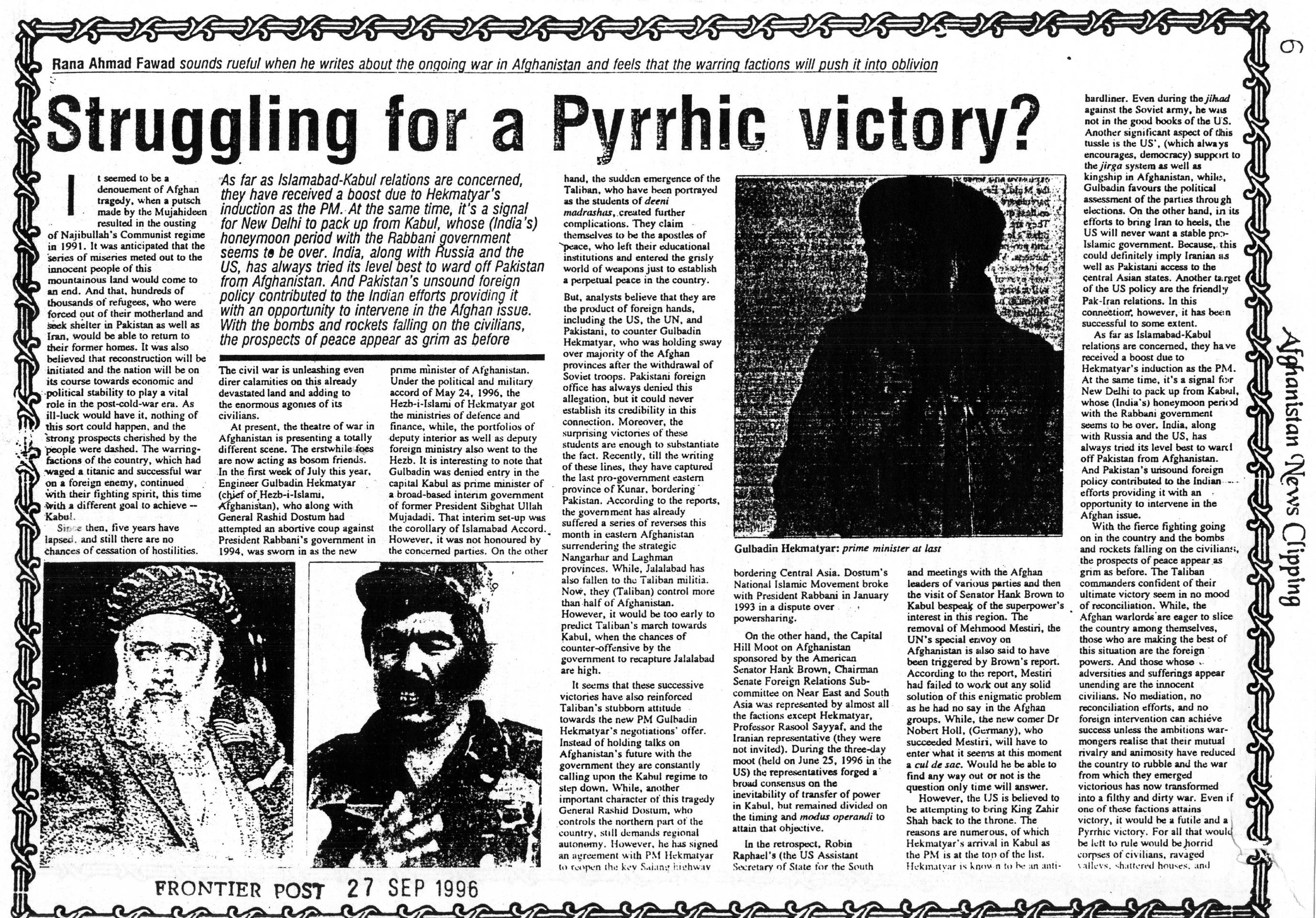


KABUL (Agencies) - A group of 200 women protested on Wednesday against the miserable conditions of women in Taliban-run areas of Afghanistan.

The women, with their heads covered in traditional Islamic fashion, delivesed a letter of protest to the office of the United Nations' special representative in Afghanistan.

There was no immediate comspecial representative $\mathrm{Dr}$ Norbert Heinrich Holl of Germany was not in Kabul.

The letter complained about the closure of schools and the restrictions on women imposed by Taliban rulers who captured the western city of Herat and southern Kandahar.

Following the fall of Herat to the Taliban, the Taliban closed the doors of all schools. universities and govment from UN officials, but the

ernment and non-governmental offices to women. who were thus deprived of basic human rights, the communique said.

Holl is trying to broker an agreement with the several Islamic factions ruling Afghanistan in an attempt to bring peace to the war-ravaged nation.

Last year when Taliban rebels overran Herat and threw out the pro-Kabul government their tirst orcter of business was to close over $3,(0)(0)$ girls schools and dismiss thousands of $\mathrm{fe}$ male teachers. Since then boy's sch(x)ls have opened but not the schools for girls.

In southern Kandahar, the Taliban have agreed to educate girls up to 8 year-old.

Mahmood Mestiri. the previous representative of the UN Secretary (jeneral. was reluctant to discuss women 's rights with the Taliban

\section{Woman's inclusion in Afghan peace talks urged}

\section{By Our Correspondent}

UNITED NATIONS, Sept 15: said Afghan women and children Supported by major women rights had become victims of the bloody groups in the United States, war fought because of the selfishAfghan women have asked the UN ness of the warlords. secretary-general Boutros BoutrosGhali to name a woman to the Afghan peace mission being constituted by him to help Afghanistan find peace and begin reconstruc. tion.

The Afghan women group led by Rukhsana Sarwar, a professor of English at the Kabul University is scheduled to meet UN assistant secretary general, Rosario Green, who is in charge of monitoring women's participation in United Nations activities.

The Afghan government has told the United Nations, not to send any women in any peace mission constituted by the secretary general.

However, women activists and groups here have urged the secretary-general to tell the Afghans that all assistance would be cut-off if they object to the inclusion of women in the peace mission.

In an interview with the New York Times, Mrs Rukhsana Sarwar
Mrs Sarwar is part of a new organisation, the Afghanistan Women's Network, which was created at the fourth world conference on women, in Beijing last year, says the New York Times. vetoed plans to send an official delegation to the conference, a group of Afghan women went without official backing to take part in a non-governmental forum held at Beijing at the same time.

The emergence of Muslim women's group over the last year was one topic discussed this week at the United Nations as women from around the world met here to assess the progress made since the Beijing conference.

Rukhsana Sarwar's husband, a professor of political science, was killed in 1993 after he returned to Kabul in 1993. She said without the involvement of women there will never be peace.
After the Afghan government

\section{World urged to help Afghan refugees}

From Our Correspondent

PESHAWAR - President of Afghan Women Council, Fatana Ishaq Gillani has diverted the attention of world countries, United Nations and others towards the miseries of the war-affected Afghans who were forced to leave their motherland as a result of fresh round of fighting and fall of the eastern provinces to Taliban. Majority of those who are leaving the country included women and children who have been deprived of their bread earners.

In an interview. Fatana Ishaq Gillani said that from the last several days, thousands of Afghan left their motherland and reached Peshawar. She herself visited Nasar Bagh refugees camp where thousands of war-displaced families with infant children are living under the open sky and without any food. She said that there is no any protection and security in the camp where the war displaced people, majority of whom are women and girls are living under the open sky.

Commenting on the situation erupted in the border provinces as well as in Kabul after the fall of Nangarhar to Taliban, Fatana Ishaq Gillani said. "Taliban on the one hand locked the schools and hospitals and on the other are unable to provide due facilities and protection to the people." She questioned that on what grounds. Taliban who consider themselves as religious scholars deprived the women of education facilities. She urged the Taliban leaders to revise their policies and let the women to earn two time meal with honour and education in their motherland.

Answering to a question, Fatana Ishaq Gilani said that common people have no concern that who is in power but need peace and tranquility in their motherland. She said that with the arrival of Taliban at Jalalabad, the civilians have left their homes due to air strikes and further fighting.

\section{NATIUN}

19 SEP 1996 


\section{Afghan women leader assails Taliban}

She was critical of the UN role which she thought was dragging its feet on the solution of Afghan conflict while the Afghans, particularty the women. continued to bear the brunt, both socially and in terms of economic hardships

Fond and edication, she went on to say, were some of important and immediate probleptis confrunting the Afghan socieiy while the religious students miitia in their ceal to enforce their brand of Isiam, had closed dowin girls schools in 16 of the provinces under their control.

"What kind of Islam is this?' she said, adding the UN and other international agencies had failed to live true to their image and exert pressure on the Taliban to refrain from doing such things. "Afghans suffered due to the Afghan mujahideeli leaders who were not prepared to sit lace-to-face with eacn other and now we have the Taliban who have barred girts from going to schools", she said.

events in Afghanistan from the fence.

\section{Afghan women seek UN help}

\section{Bureau Report}

PESHAWAR: Afghan Women council has asked the United Nations to come to the fore and play its role for the rights of women in the present day situation of Afghauistan.

A meeting of the council presided over by its patron Fatana Ishaq Gillani on Sunday noted with concern that Taliban leadership has banned women from working and no respect was being given to their rights as muslims and liuman beings.

Fatana said that it wass a matter of great concern for the women of Afghanistan that Tadiban have still not opened female schools in Kandahar and Herat after taking its control more than a year ago. She said that Afghan women deserve a better deal as they have sacrificed their loved ones for Islam and Afghanistan during the last 18 year of war.

Meanwhile. Musarat Hilali Advocate member Humau Rights Comunis sion of Pakistan has criticised Tadiban for stopping them from work and closing down their schools. She said it was against the teaching of Islam to prevent female from getting education as the holly religion lias make it mandatory ior both male and female muslins to get educated.

She said by asking more than half of the Afghan population to stay indoor would bring no good and will further worsen the economic condition of the Afghan society. She also requested the United Nations and international NGOs to press upon the Taliban to protect women rights. 


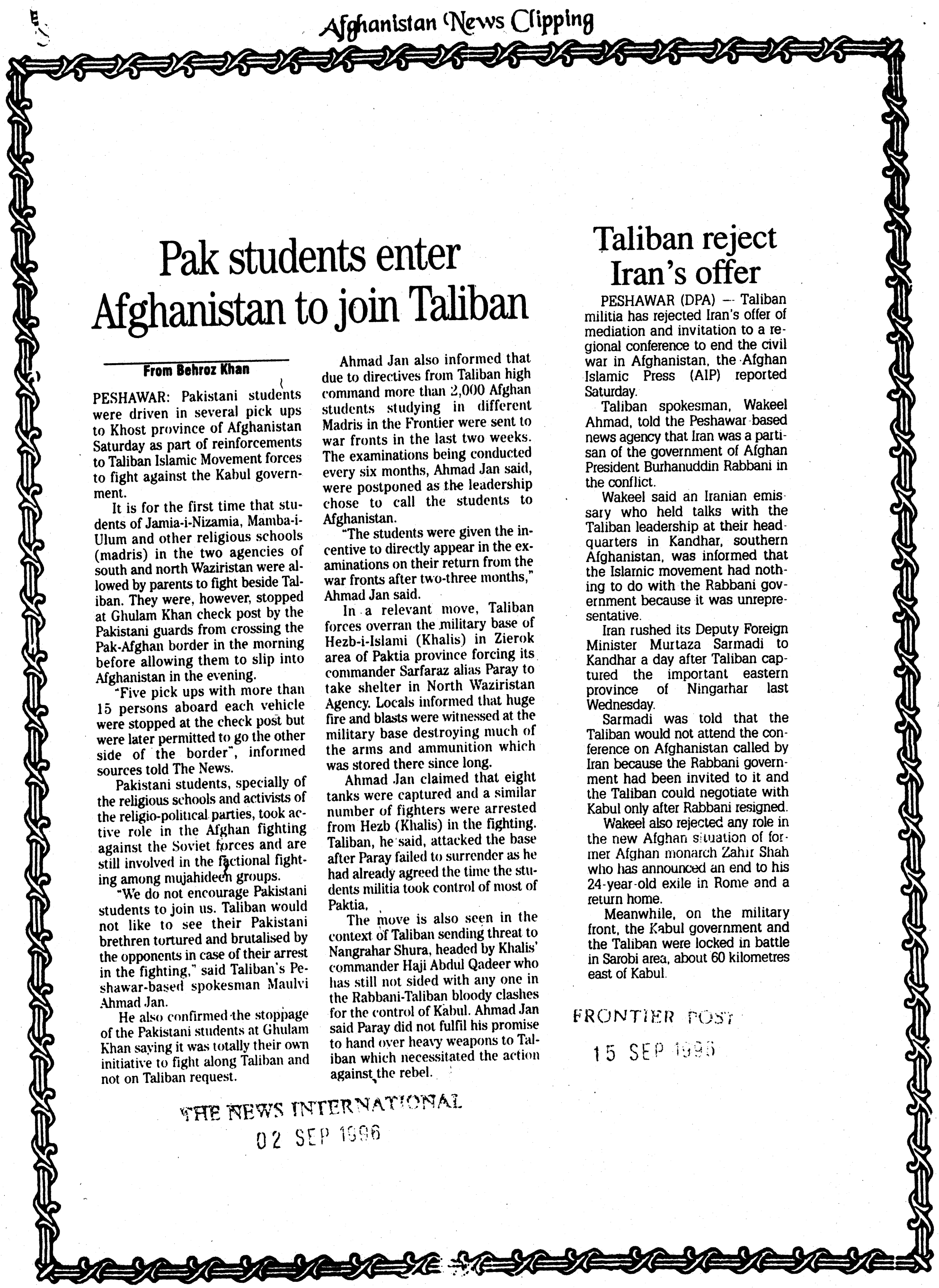




\section{0 Taliban aiming to sever Kabul's link with Jalalabad}

KABUL, Sept 5: A large strike force of the Taliban on Thursday headed north towards Sarobi on the main national highway linking Kabul with Pakistan border, military sources said.

"An estimated 300-400 Taliban backed up by 10 tanks was on the move today," a military officer co loyal to Afghan President of Burhanuddin Rabbani told AFP.

He said the aim of the Taliban strike force was "to cut the KabulJalalabad highway and threaten Tagob Valley" if possible.

There was no immediate confirco mation of the Defence Ministry claims.

Sarobi is a district centre $75 \mathrm{~km}$ west of Kabul on the main road to Jalalabad, which is close to the Pakistan border.

Although Jalalabad is under the control of a shoora or council which has declared neutrality, the Kabul covernment has been attempting to 2. woo them on side with offers of military assistance.

Sarobi, which is defended by fighters from Prime Minister Gulbuddin Hekmatyar's Hezb-i Islami faction, controls access to the Tagob Valley, which is strategically important as it opens out onto the plains $50 \mathrm{~km}$ north of Kabu where the government's vital ment's vital AFP

\section{Taliban favour}

\section{AFP}

ISLAMABAD: The Taliban militia Wednesday said it would welcome former Afghan king Zahir Shah playing a role in the establishment of Islamic law and peace in the war-ravaged country.

"We invite not only Zahir Shah but also other Afghan personalities living in Europe to return and help establish peace and Islamic order in Afghanistan," said a Taliban leader, Amir Khan Muttaqi.

Muttaqi said the former king and all his family members "are welcome to visit Taliban-held areas in Afghanistan."

"Peace, justice and order prevail in our areas because we have introduced a system of governance based on Islamic principles," said Muttaqi, who is in charge of the information wing of the Islamic militia.

Muttaqi did not spell out what specific role or position Taliban
Bagram airbase is located.

Although some skirmishes between the Taliban attacking force and pro-Kabul factions have already been reported the student militia still have a long way to travel before they reach Sarobi.

It is unclear yet which route the Taliban may select for their reported march on Sarobi.

From their bases in southeast Kabul there is a good motorable road through the Lataband Pass to Sarobi but this is heavily guarded by troops loyal to Rabbani's topgun Ahmad Shah Masood.

Further south there is another route once used by Hekmatyar's Hezb-i-Islami, starting from the Spina Shega base near the Pakistan border which was captured by the Taliban about 10 days ago.

This mountainous route is jointly guarded by fighters from Hekmatyar and Masood, who claim to control all the highground thus making a Taliban advance very difficult.

Meanwhile to the southwest of the capital there was a reported early morning exchange of bombardment across the frontlines between the Taliban and pro-Kabul factions but the national highway remained open to civilian traffic.-

\section{Zahir's role}

leadership had in mind for the exking in case he returned to Afghanistan.

The Zahir Shah option was revived by US Congressman Dana Rohrabacher who said last week during a visit here peacc could be quickly restored in Afghanistan under an administration led by the former king.

The Republican congressman said he would brief the former monarch living in Rome about his talks with Pakistani officials and representatives of Afghan factions.

Following Rohrabacher's statement, a spokesman of the Pakistani Foreign Office said Islamabad was not "averse" to the idea of return of Zahir Shah to power in Afghanistan if it would bring peace to the country.

The proposal has been put forward in the past by various quarters but was strongly opposed then by most Afghan mujahideen factions.
Taliban busy in talks with Sarobi leaders

\section{From Shamim Shahid}

PESHAWAR - Taliban are busy in talks with rulers of Kunar province, bordering Bajaur Agency of the tribal belt, but they become ahead with the Rabbani government's loyal troops to the east side of Sarobi town. Early in the morning, there was reports of fierce fighting in the area but the situation was reported peaceful in the afternoon on Saturday.

However, Taliban have claimed of capturing Rekhmeen Tangi and a post near to Speena Thana, around IO kilometres toeast of the Sarobi town. They also confirmed a peaceful situation in the area. However, they avoided to comment when questioned that on what grounds they stopped further advancement towards the Sarobi town.

\section{NATION \\ 05 SEP 1996}

\section{Hizb-controlled Paktia province falls to Taliban}

\section{From Our Correspondent}

MIRAN SHAH (North Waziristan Agency) - The Hizbe Islami of Gulbadin Hekmatyar received another set back when one of its last stronghold in Paktia province included an arms depot fell to Talibaan.

The reports from across the border. reveal that Hizbe Islami's Commander Jalil alias Khalili was controlling wellarmed headquarter in Tehsil Wozi of Paktia province. The Talibaan is forces launched an attack against the Hizbe Islami headquarter for the province and after fighting succeeded in its capturing. The Taliban claimed that after capturing the markaz, they seized two tanks, four APCs and 20 trucks loaded with arms at Alauddin and Sargor areas, on some distance from the markaz.

\section{NATION}

O 6 SEP 1996 


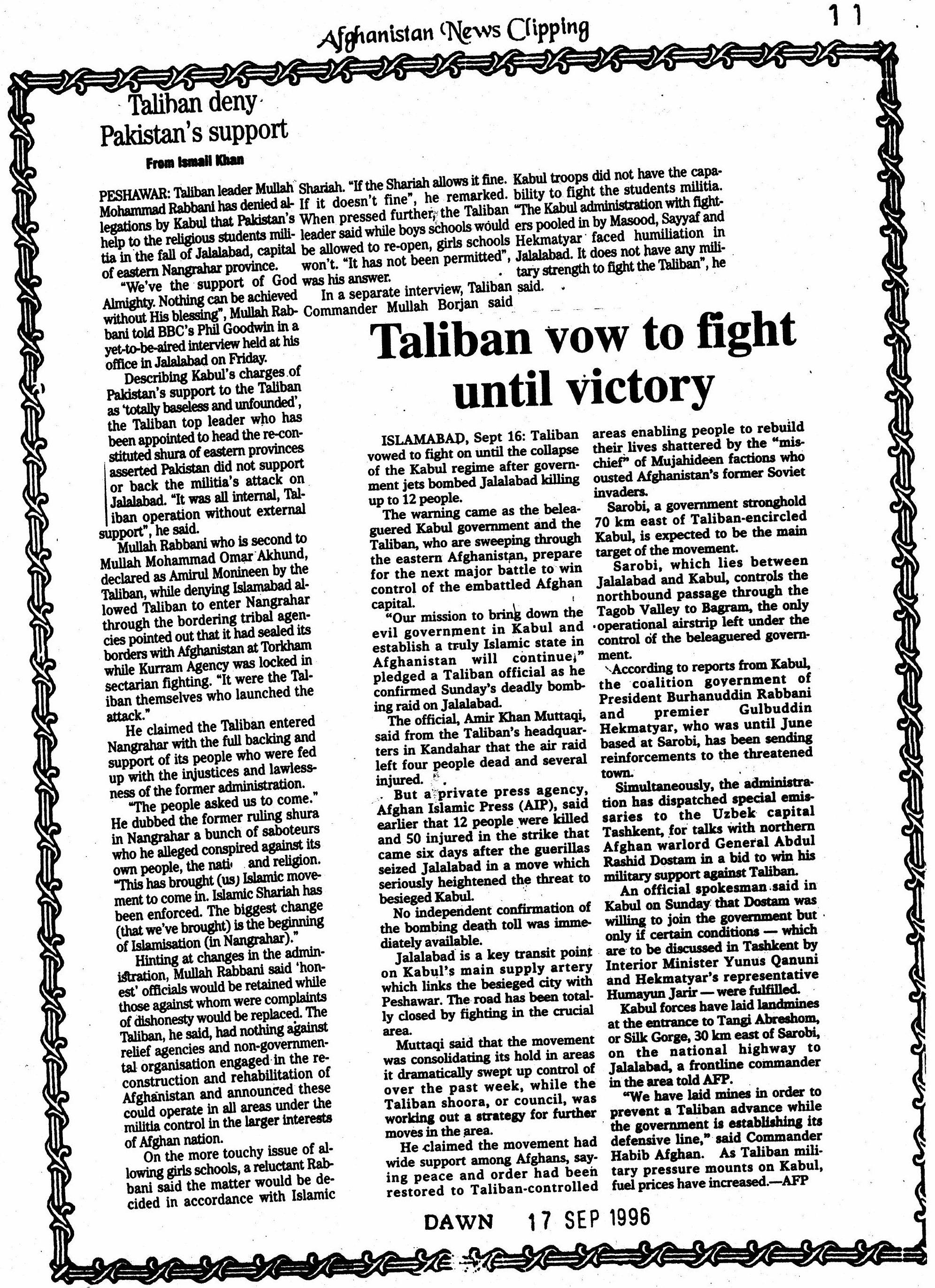




\section{$x \Rightarrow 2 \Rightarrow 3 \Rightarrow$ \\ Taliban's murky leadership is unpredictable}

KABUL: The Islamic Taliban's opaque and mysterious leadership structure keeps analysts and politicians guessing about the hard-line group's next move, observers said.

The militia, based in the southwestern Afghan town of Kandahar, is run by a series of shooras, or councils, stretching up from local level to the movement's top leaders.

But few people, including many of Taliban commanders based around the besieged Afghan capital Kabul, really understand how the shooras work or who actually decides the movement's policy.

"It's unclear whether the Taliban have ever really had a detailed plan to carry our their goal, or whether they simply flounder from one snap decion to the next," a foreign observer here said.

"Many of their military victories were almost accidental as very often they expected a long battle for a particular place, but instead found thereselves being welcomed by the local populations who were ready for any change," he added.

Most analysts believe that when the Taliban took the western city of Herat a year ago, they were more surprised than anybody else.

Government troops collapsed and fled as the militiamen approached expecting to lay a long and perhaps unsuccessful siege to the city. Instead the militiamen to sweeped into the city centre without a shot being fired in anger.

The movement is led by a group of mullahs, or Muslim holy men, who also rule the vast and sprawling movement through a council.

One man - Mullah Omar stands out as the group's nominal chief. Omar is a one-yed veteran of the mujahedeen war of resistance against Afghanistan's former Soviet invaders who has refused to meet any foreigners and who is rarely seen by anybody at all.

The self-styled "king" of the of wortd's Muslims, Omar appears from of the outside to be locked in a constannt battle of ideologies with his shoora colleagues.

Observers say there are splits within the Taliban between the hardliners, the more moderate leaders and v the strictly religious chiefs. Mullah Omar is believed to lead a moderate camp. - AFP
Taliban lock up educational institutions in Jalalabad

From Shamim Shahid

PESHAWAR - The already waraffected students in Afghanistan are facing a new era of uncertainty and confusion as Taliban after capturing the border Nangarhar province ordered locking up of all educational institutions including Jalalabad Medical College, University, Engineering Faculty and others.

With thisdecision, around three thousand students all over that country returned to their homes and now worried about their fture. Among the affected students, also included hundreds of Pakistanis.

The students on conclusion of their summer vacations when reached Jalalabad University and Medical College were informed by Taliban to either go back to their homes or took kalashnikov and join their struggle for the restoration of a peaceful atmosphere in Afghanistan with an Islamic system of life.

The university buildings and hostels have been occupied by Taliban soldiers and they didn't allow the students to enter their rooms.

While the teachers have already left the border town of Jalalabad either for Peshawar or for other parts of Afghanistan.

The reports collected by this correspondent from a number of Pakistani and Afghan students of Jalalabad institutions reveal that around 300 girl students including $\mathbf{4 0}$ from NWFP and tribal areas were affected with the closures of institutions. There are around 200 Pakistani students only in Jalalabad Medical College.

The Taliban leaders told The Nation on telephone from Jalalabad that they give more priority to the restoration of peace in Afghanistan. They confirmed shuttering of all educational institutions not only in Jalalabad town but also in other parts of the eastern provinces. They said that after the restoration of complete peace, they would think about their reopening.

\section{NATION}

\section{SEP 1996}

Taliban men told to wear beards, quit smoking

ISLAMABAD, Sept 24: Taliban have decided to expel from its ranks all soldiers who do not wear beards or are addicted to cigarettes, the Afghan Islamic Press (AIP) agency reported on Tuesday.

AIP said the decision was part of Taliban's Islamic code of conduct announced by them for their newly captured provinces of Nangarhar, Laghman and Kunar.

Soldiers of the provincial defence forces were not subject to such Islamic discipline before they surrendered and joined the Taliban.

AIP said the code of conduct announced in Taliban's mouthpiece Nangarhar, issued from Jalalabad, capital of Nangarhar province, also decreed that women venturing out of their houses must be veiled.

Girls schools have been closed in the three provinces. They have also been shut down in 14 other provinces the Taliban has captured.

The Taliban, an Islamic reformist movement, arose from madaressahs for young men in southern Afghanistan two years ago.

AIP said the Taliban command has asked young students from these mens schools who took part in the battles to capture Nangarhar, Laghman and Kunar to return to their lessons.-DPA

\section{Rabbani's} commanders held QUETTA (PPI) - Taliban mujahideen have arrested four $;$ commanders of the Rabbani forces in the border areas of Islam-qlah, adjacent to Iran. According to central ministry of information of Tehreek Islami Taliban Afghanistan, these commanders were engaged in terrorists activities in Herat province. They also included commander Zareef and commander Sozak. Three hundred klashnikovs, 16 rockets, four powerful wireless sets and other military equipments were also recovered from their possession.

FRONTIER POST 


\section{SEP 1996 \\ Taliban re-open highway used by retreating govt forces}

KABUL: Civilian traffic was allowed by the Taliban religious militia to use the northbound highway out of the Afghan capital of Kabul Friday afternoon. after a temporary closure in the morning, according to reports.

Following the Taliban's pre-dawn capture of the capital after the total collapse of the government defence, the road used by retreating troops was closed until mid-afternoon local time (late morning GMT).

The Taliban themselves used the road in pursuit of retreating Kabul troops, who have reportedly established a new defensive line at Jabal us-Seraj, just under 80 kilometres from Kabul. The Taliban have established themselves at the Parwan provincial capital of Charikar, just 14 kilometres south of Jabal us-Seraj.

Abandoned on the side of the na- tional highway, not far from the northern Kabul district of Khair Khana, were numerous tanks, truck-mounted 40 barrel rocket launchers and other military vehicles.

They had either broken down during the goverument's withdrawal from Kabul or had been abandoned in the chaos and panic of retreat.

The former government military airbase at Bagram, located some 50 kilometres north of Kabul, was also seized by the Taliban Friday morning after it was evacuated by government forces without a fight.

Surprisingly, the Taliban displayed very little military presence in Kabul Friday, which led some Western observers to wonder how government forces had been so easily defeated.

President Burhanuddin Rabbani's miliiary strongman and the architect of Kabul's defences, Almmad Shah Masood, was understond to have decided orr a strategic withdrawal fiom Kabul in order to avoid unecessary bloodshed. The 'Taliban rapidly advanced on Kabul after their lightning capture of the district centre of Sarobi, some 70 kilometres to the east of the capital. Despite assurances by government spokesmen that tile coalition of Kabul military forces would be able to defend the capital against the reientless onslaught of the religious militia, they failed dismally.

Masood has jreportedly concentrited most of his fighting furce in his home patch, the Panjsher Valley, where his successful defence against repeated offensives by the Soviet army during their 10-ye:ar vicupation of Afghanistan earned him the sobriquet "Lion of the Panjsher:"-AFP

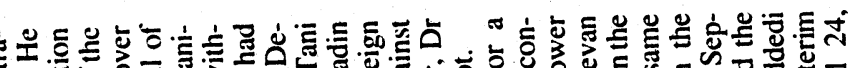

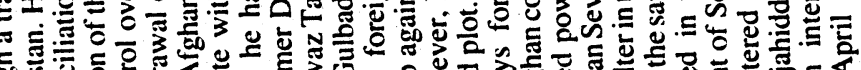

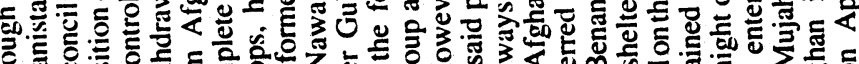

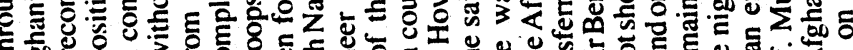

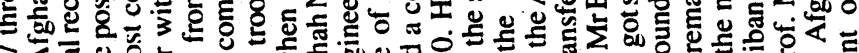

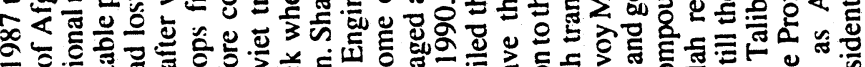

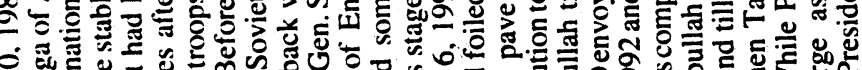

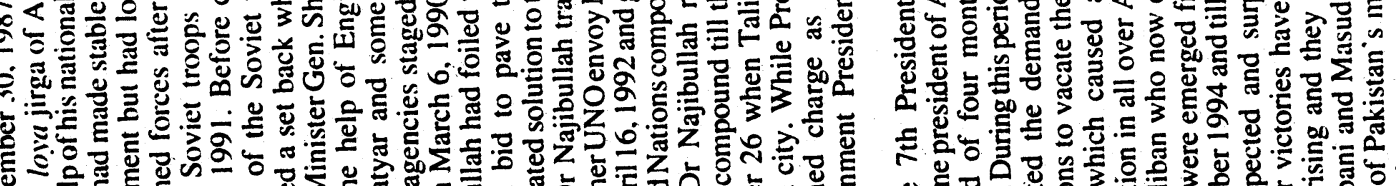

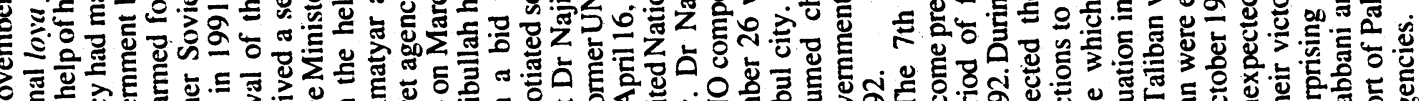

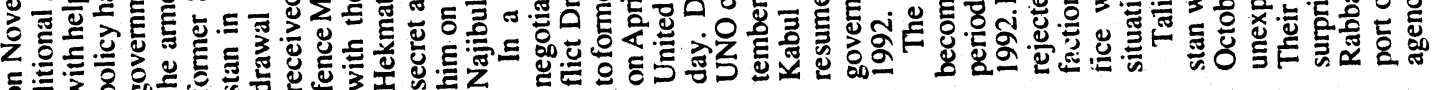

\section{宊}

골

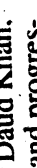

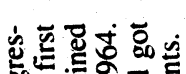

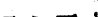

\section{至官}

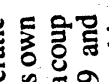

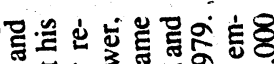

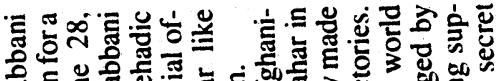

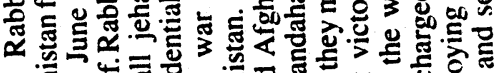

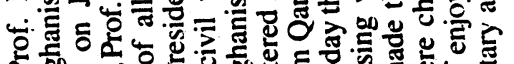

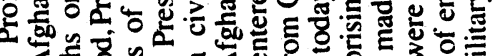

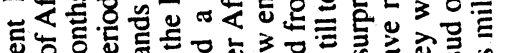

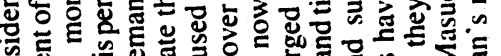

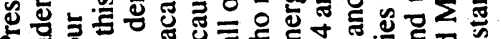

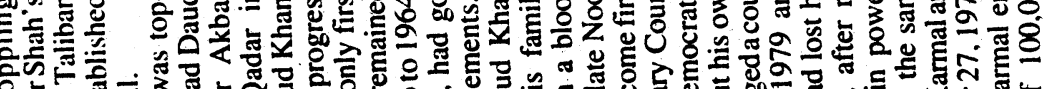

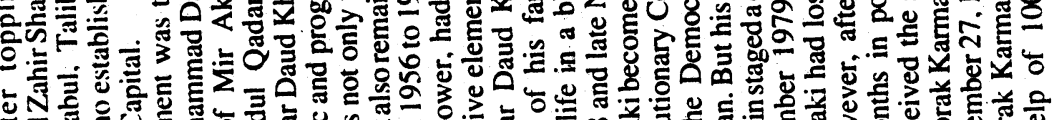

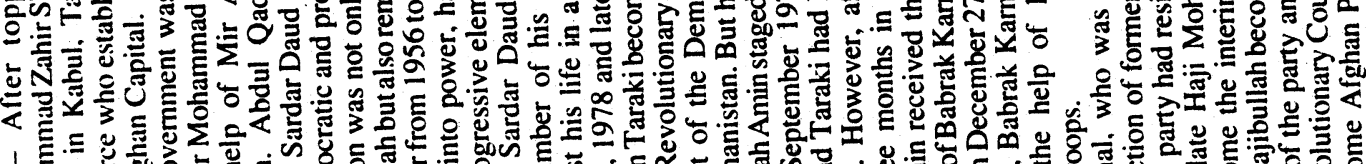

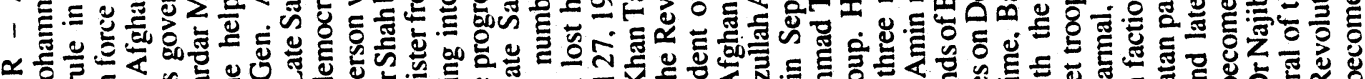

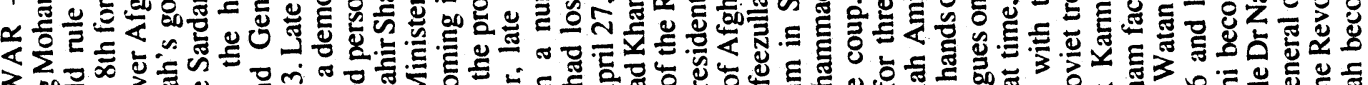

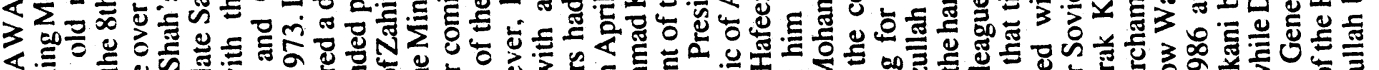

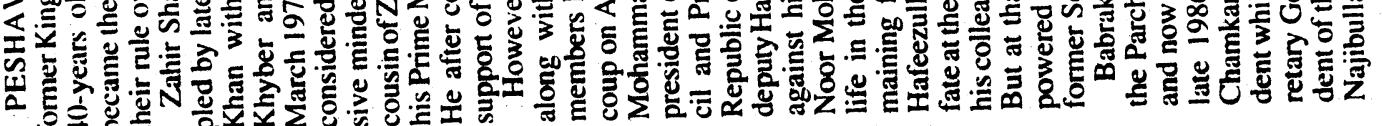

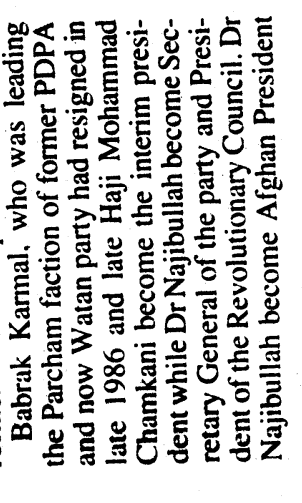




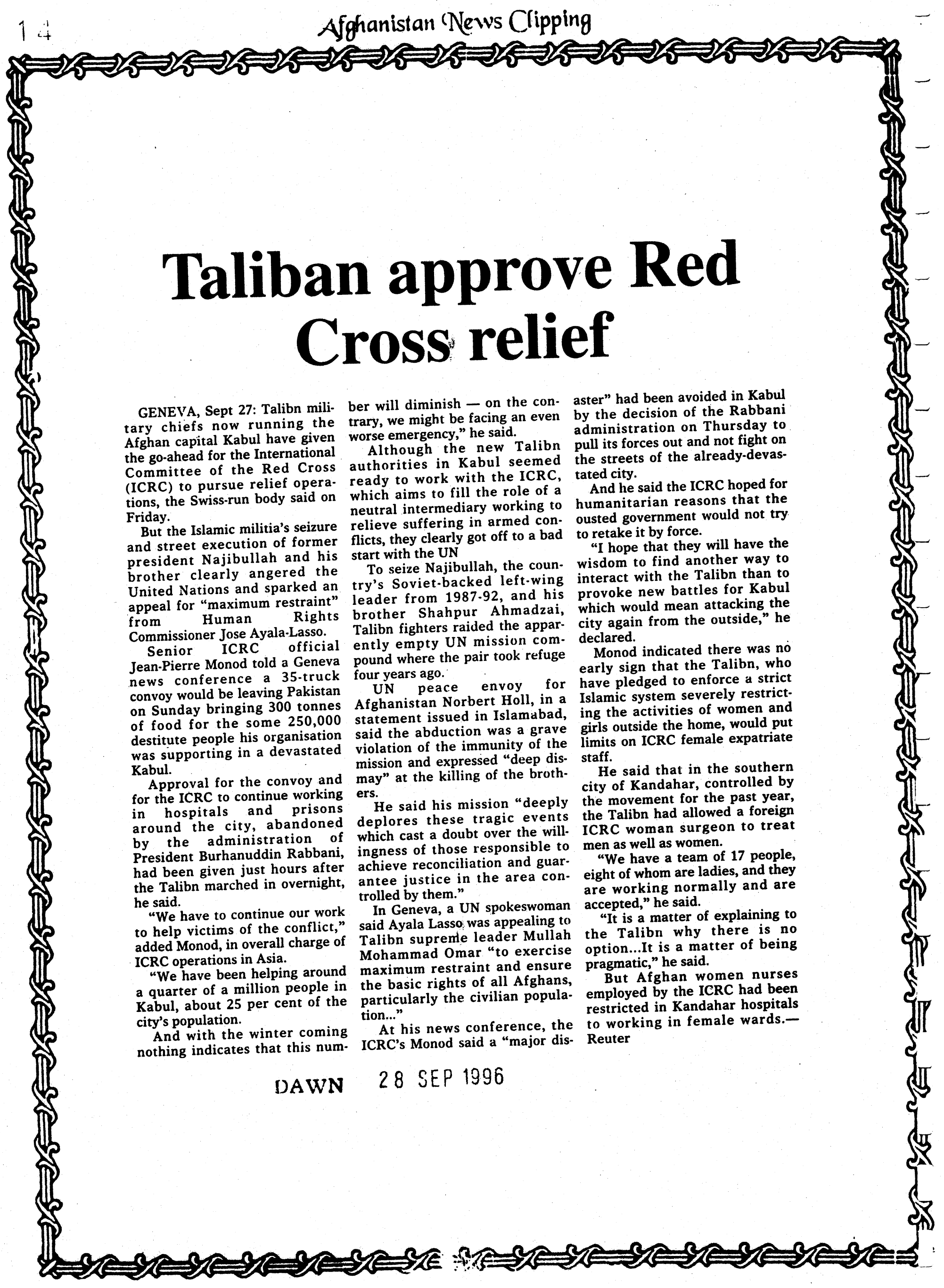




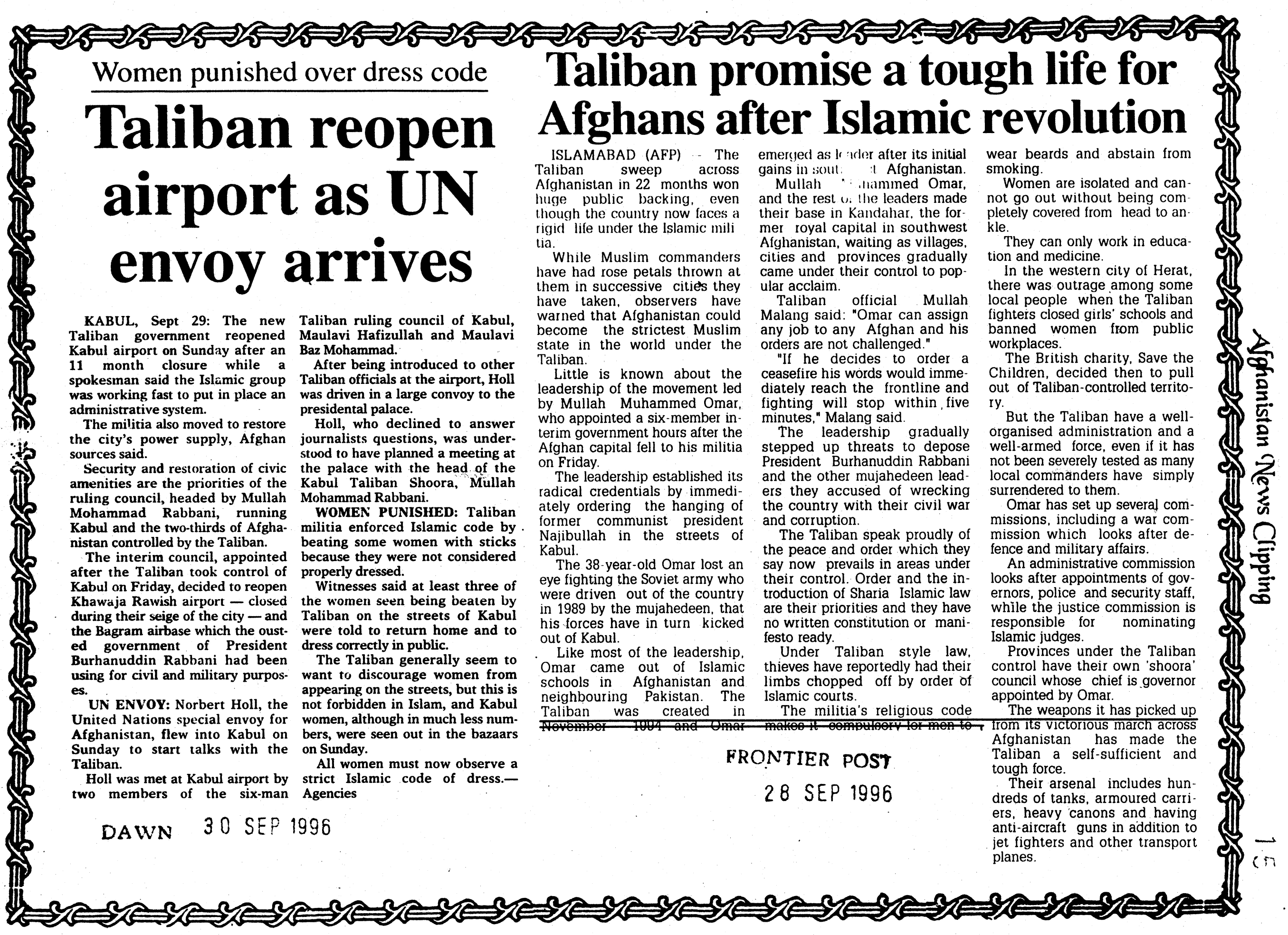




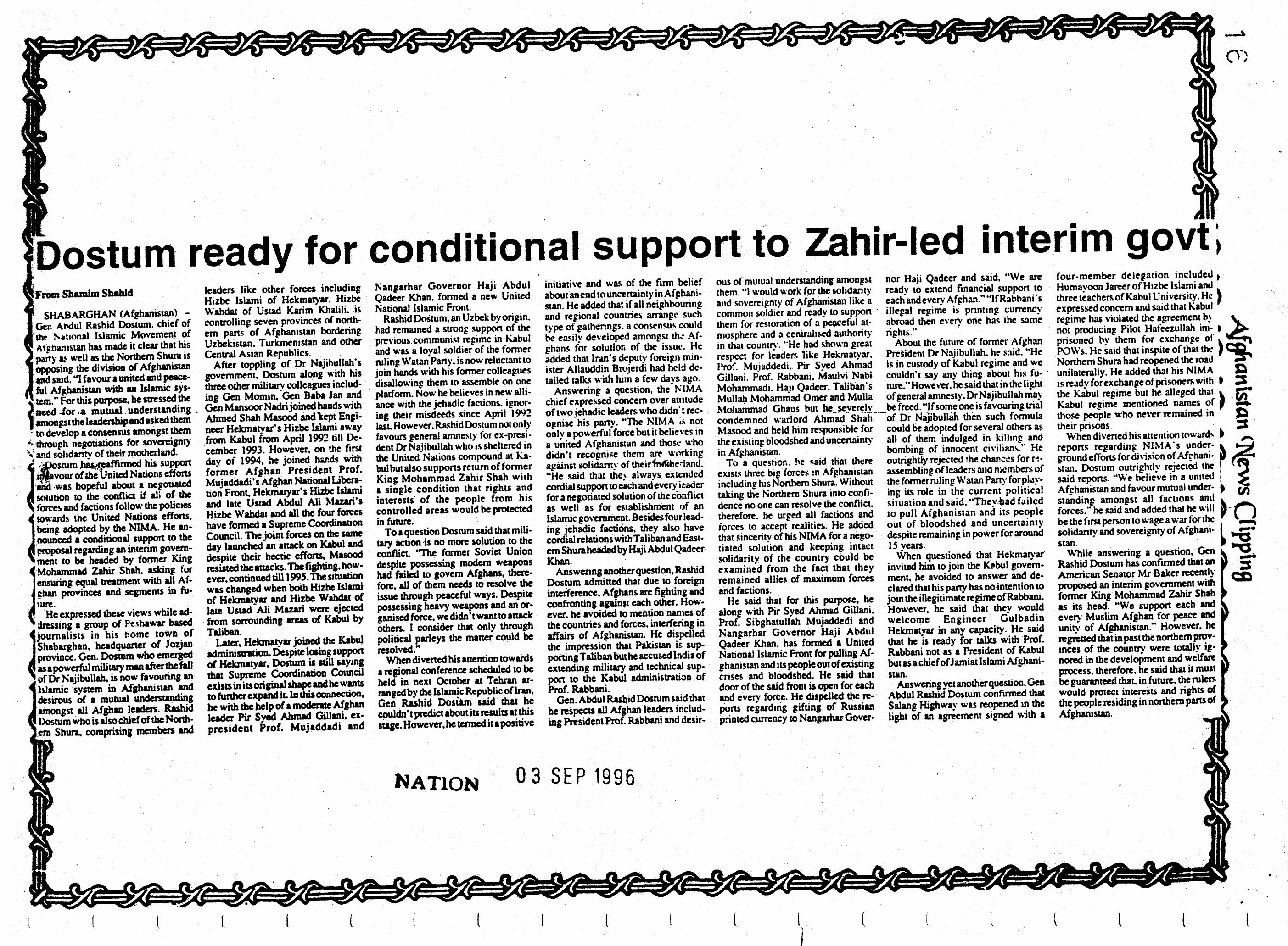




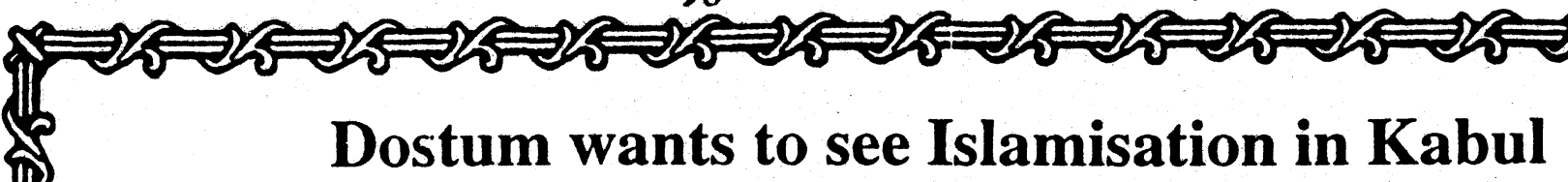

From SYED BUKHAR SHAH

SHIBARGHAN -- Criticisir:g dual policies of Afghan leaders. Jumbish $\cdot \dot{\text {-Milli Islami }}$ Afghanistan General Abdur Rashid Dostum has said they did not practice what they preached.

Talking informally to a delegation of Pakistani journalists which called on him at Junbish headquarter at Shibarghan, in Jauzjan province on Sunday, he said such Afghan leaders having contradiction in their words and deeds could not succeed in their mission.

Dostum claimed that the Afghan leaders including Noor Mohammad Tarakai, Hafizullah Amin, Babrak Karmal, Dr. Najeeb and President Burhanuddin Rabbani were neither sincere with Afghan nation nor with Afghanistan. These leaders had always deceived their own na tion but now the people had wit nessed the result of their hypo critic policies.

Arppreciating the role of Pakistan and its people which they played during the Afghan Jehad, General Dostum reminded that it was only due to Pakistan that we are independent today. We would have remained slaves like the previous people has Pakistan and its people not sup ported us against the former USSR. Pakistan has protected our honour and not a single Afghan could forget it in future.

"I have asked President Rabbani as to why you are join ing hands with India and Russia instead of Pakistan. Pakistan has provided you shelter but you de stroyed Pakistan embassy in Kabul. I have stated so in the UN meetings also", he said adding. "we are enjoying good friendly relation with Pakistan. I have held meetings with President Leghari, Prime Minister Benazir Bhutto and former president of Pakistan Ghulam Ishaq Khan also and I want to establish bet-

ter relations with neighbouring countries".

General Dostum supported the formation of an Islamic goverrment in Afghanistan which could guarantee equal rights to all including women. He cited the example of Islamic government in Iran

He said it was his earliest de sire to impart education to Afghans, who, he added were in dire need of modern knowledge. "Our people cannot differentiate between a horse and an automobile", he said and narrated a story about a group of Ulema whom he had requested to visit an area called Kohistan to settle a community dispute.

"When they got inside the jeep, they were in a fix to how to sit on the seats, "Dostum said. "And when the jeep started moving, they were excited because, as one of them put it, it was stronger than a horse"

Dostum observed that the people of north had been kept backward intentionally by the previous rulers. The Russians had supplied the gas facilities from north Afghanistan even to Russia and Ukraine but the people of this area were deprived of it for the last 40 years. Similarly, he said, according to UN census, Faryab was the second thickly populated area after Kabul but the roads had not been constructed and now we have done it. Now we will demand the rights of north Afghanistan from every ruler. "I am opposed to the division of Afghanistan but the opponents had launched a propaganda against me only because I am demanding the rights of north Afghanistan, he remarked.

"We will provide gas facilities to the people of north as we have started work on the supply of gas from Shibarghan to Mazar Sharif.

We have also improved the deteriorated condition of roads from Mazar to Faryab and now the people could reach Faryab within one and a half hour instead of two days.

Later the journalists were taken to the sites of development works where gas pipes have been had laid on six kilometres from Shibarghan to Mazar Sharif and work completed on FaryabShibarghan road.

Beside restoring law and order in his area, Dostum said that, "we have constructed hospitals and schools in all the provinces under his control. We have also constructed a big hospital with the cooperation of Turkey. The law and order situation in his areas, he said could be judged from the fact that, "you will not hear a single fire here."
"I have always been compelled to fight wars. I had gone to Turkey to hold negotiations with President Suleman Demiral and Prime Minister Turghat Ozal but I had to return when I was informed that staunch supporter of President Rabbani, Ahmad Shah Masoud had attacked Mazar Sharif. We have always opposed wars but Ahmad Shah Masoud had besieged our headquarter Qila Jangi after which I consulted Ulema and sought their advice in this connection. According to the Ulema, I had the right to defend and that was why I repulsed them. Ahmad Shah Masoud left tanks and other weapons behind and fled away from my area. They also refused to accept our status and were not recognising our representatives in the meetings. They were not recognising Junbish-i-Milli as a power but we were true and they were not sincere. Today we have opened the road, we will send food and other items on Salang road but they had tried to sabotage the whole game by bringing changes in the prisoners lists. We are stronger and no one could dictate us. Neither we are weak nor we have opened the Salang Highway under any pressure", Dostum continued.

Junbish-i-Milli chief said, "we are enjoying better relations with Taliban. We have a long border with them. We have also formed a five-member commission to hold negotiations with Taliban and we have no problems in this connection. I have also held meetings with Taliban leaders in Islamabad for three to four hours. Taliban have controlled over a big portion of Afghanistan and I am compelled to hold negotiations with them".

\section{ERONTIER POST}

\5 SEP 1996 


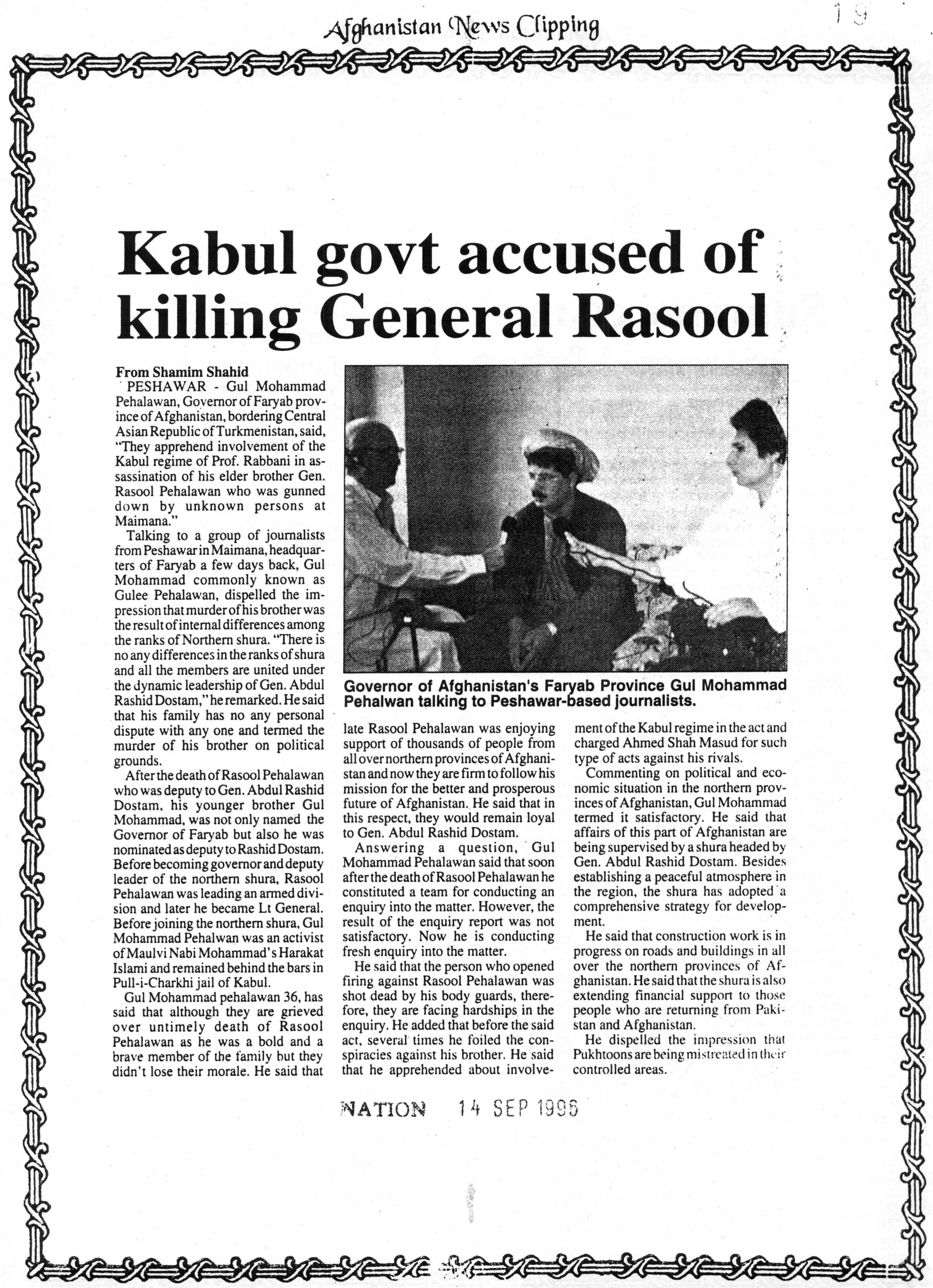




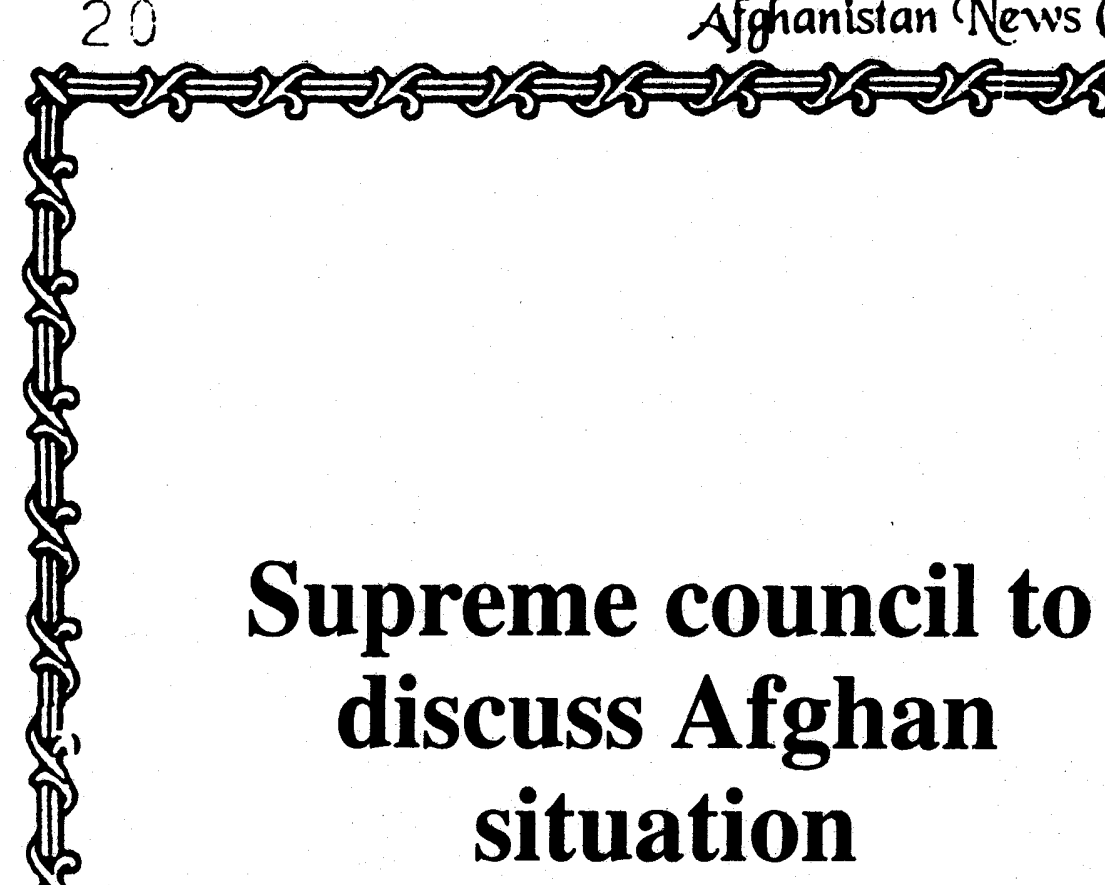

Bureau Report

PESHAWAR, Sept 15: A fourmember delegation of the Supreme Coordination Council of Islamic Revolution of Afghanistan (SCCI. $\mathrm{RA}$ ) has left here for Mazare sharif to discuss the latest developments in Afghanistan vis-a-vis Taliban advances in eastern provinces of the country and to take a unanimous stand on the imbroglio.

The SCCIRA,it would be recalled, remained a formidable opposition alliance of four parties till Hekrnatyar's rapproachment with the Rabbani regime with other members being northern warlord Rashid Dostum's Jumbishe Milli Islami, Prof Sebghatullah Mujaddedi's Afghan National Islamic Front and Hezbe Wahdat Khalili faction.

The delegation comprising $\mathrm{Dr}$ Talib of Hezbe Wahdat, Hashmatullah Mujaddedi and Sulemanyari of ANIF and Gen.Painda Khan of Jumbishe Milli will also visit Bamyan province controlled by Ustad Khalili's Hezbe Wahdat after its meeting with Rashid Dostum in Mazare Sharif.

According to Maulvi Turkistani, a representative of Dostum, the need for sending the delegation has arisen to assert the SCCIRA in the wake of recent dramatic developments in the war-torn country. He said the three opposition parties which have maintained a neutral

stance so far would now try to cre ate a consensus whether to side with the Kabul government or to put their weight behind Taliban militants in the present circum. stances or to continue their neutral position.

In the meantime, a Rabbani regime delegation comprising Humayun Jareer, a right hand man of Afghan premier Hekmatyar, and Yunas Qanooni, the all important aide of the Kabul regime are also embarking upon a visit to Mazare Sharif in a bid to pursue the northern warlord Gen.Rashid Dostum to extend his support to the Kabul regime in the ongoing war with Taliban.

Another purpose of the visit has been stated as asking Dostum to provide sufficient food supplies to Kabul in the aftermath of KabulJalalabad highway's closure following the fall of Nangarhar province to the Taliban last week.

The Taliban,it is worth mention. ing, have declined Iran's recent invitation to attend an intra Afghan dialogue in Tehran, saying that they will not attend any conference in which Rabbani is invited as president of Afghanistan. In such a situation the observers give little chance to the efforts of a truce and a negotiated settlement between the warring factions vying for the power seat of Kabul.
Dostam refuses

\section{to recognise} Taliban admin

F.P. Monitoring Report

PESHAWAR -.- General Abdul Rasheed Dostum, who controls six provinces in Northern Afghanistan, has refused to recognise the Taliban administra tion in Kabul, BBC quoting top cormmanders of the northern warlord reported Sunday night.

In its late night Urdu bulletin. the radio said that top comman. ders of General Dostum had termed enforcement of Shariah by Taliban dangerous and condemned the summary execution of former Afghan president $\mathrm{Dr}$ Najibullah.

They said that no govermment could be formed in Afghanstan till such a time an intra Afghan dialngue was held betwet:! Generial Dostum, the depesend president Burhanuddin Rabban and other key Afghan leaders.

The BBC corresinondent report ed from Mazar $\cdot \mathrm{i}$-Sharif that most of the people in the city seemed to be ardent supporters of Dostum and rid not want Taliban to nuve lowards northern Afghanistan.

\section{FRONTIER POST}

\section{DAWN 16 SEP 1996}




\section{Dostam joins Kabul against Taliban}

\section{Sends 2,000 troops to reinforce govt forces}

\section{From Ismail Khan}

PESHAWAR: In the backdrop of dramatic events unfolding in Afghanistan, Junbish-i-Milli of Gen Rashid Dostam at a meeting of top military commanders in Mazar-i-Sharif on Monday decided to dispatch two thousand troops to bolster the defenses of strategic Sarobi against the onslaught of Taliban.

A highly reliable source disclosed the meeting, attended by 50 top commanders of Junbish-i-Mill had two sessions to discuss the situation arising out the Taliban's successes in recent days - the fall of Nangrahar and Laghman and its implications for Kabul.

The second session held at the office of foreign ministiy in Mazar, last till Monday afternoon. Presided over by Dostam, the meeting again held threadbare discussion on the issue and decided to send in re-enforcements to Sarobi in aid of Hezb-i-Islami and Jamiat forces defending Sarobi against the forward-thrusting Taliban.

The source said Dostam's engagement in the meeting delayed his departure for Tashkent, Capital of Uzbekistan where he was scheduled to hold further negotiations with

\section{Continued from Page .}

Rabbani and Masood accusing them of being untrustworthy.

The source said the decision has come in the backdrop of two rounds of secret meetings between Dostan and Masood held in Moscow and Tashkent. The first meeting between the hitherto adversaries took place on the 2.2nd of June in Moscow followed by a second meeting in Tashkent the date of which the source could not recall but placed it somewhere after the fall of Hezb-i-Islami base. Spina Shaga in Pakhtia, on August 25.

The source further informed that Dostam was expected to leave for Tashkent in the next 12 hours and was likely to ink a document brought by Interior Minister Yunis Qanuni and Hekmatyar's son-in-law Humayun Jareer.

"He is close to an agreement", the source confided, adding Dostam had been offered to head the defence ministry, become a senior deputy to President Rabbani and at the same time lead the political and military command of the north. The source sald Dostam was likely to nominate his deputies to the three important posts in Kabul.

Reports said the Junbish leader is under pressure from Uzbekistan and Russia to mend fences with Kabul against Taliban.
Sardar Abdul Wali, son-in-law and special emissary of former Afghan king, Zahir Shah, is expected to reach Pakistan in the coming days to prepare the ground work for the'ex-monarch's arrival here.

Afghan sources informed The News that Sardar Wali would hold talks with Pakistani authorities in Islamabad also meet Afghan supporters of Zahir Shah. He would later give the green signal to the ex-king to prepare for his journey to Pakistan.

Zahir Shah had recently announced an end to his 24-year self-exile to play a more active role in resolving the Afghan problem.

Sardar Wali had paid a visit to Pakistan earlier as well to gauge the mood of the Pakistani government and also Afghans and assess Zahir's Shah's chances in case he opted to return to Afghanistan.

Nangrahar radio starts: The Taliban resumed transmission of radio Nangrahar, closed down a day before the students militia captured Jalalabad.

Maulvi Mohammad Ishaq Nizami told The News the radio unlike the paut would have morn. ins and evening transmissions, featuring news and Islamic programmes.

Another report said the Taliban flew into Jalalabad, a helicopter, found abandoned in Laghman's Kargha district by the retreating a two-member delegation from Kabul on a possible agreement with President Rabbani's government.

The source did not know when the troops would be sent to Sarobi but said the re-enforcements would be made through the Salang Highway, the strategic lifeline extending from north to south linking Kabul which was reopened on August 29. He said the troops would be camouflaged as Hezb$i$-Islami but would remain under the overall command of Junbish-i-Milli.

"Junbish apprehends the Taliban pose a challenge to its rule in northern Afghanistan once they take over Kabul", said the source. This is the reversal of September 1995 situation when Dostam locked in fighting with Masood in the north came in aid of the ed his jets to bomb the Shindhand airbase

to help them capture Herat, the source said.
"This is basically an alliance between two forces fearing a common enemy", he said.

The decision is a somersault on part of Dostam who

\section{Continued on Page}

Kabul again blames: The embattled Afghan government Monday accused elements in Pakistan of interfering in Afghanistan following the dramatic advances of the Taliban.

The state high council said at a meeting here that "some elements" in Pakistan, including the interior minister, were trying to disrupt relations between Islamabad and Kabul.

The council asked pakistan's islamic parties, parliament, politicians and the people to block the involvement of the "selfish elements" in the internal affairs of Afghanistan, said Abdul Aziz Murad, a spokesman for President Burhanuddin Rabbani.

Babar denies: Interior Minister Naseerullah Babar on Monday reiterated his denial of allegations of Afghan government that Pakistan was involved in the recent successes of Taliban militia.

"Pakistan believes and acts upon the policy of non-interference in the internal affairs of any country including Afghanistan," he told APP in reaction to the recent spate of allegations of Kabul rogtime.

"We don't side w , any Afghan group and we are neutral in the infighting in Afghanistan." Babar said Kabul is trying to pass the buck on others, "as it has done in the past." 


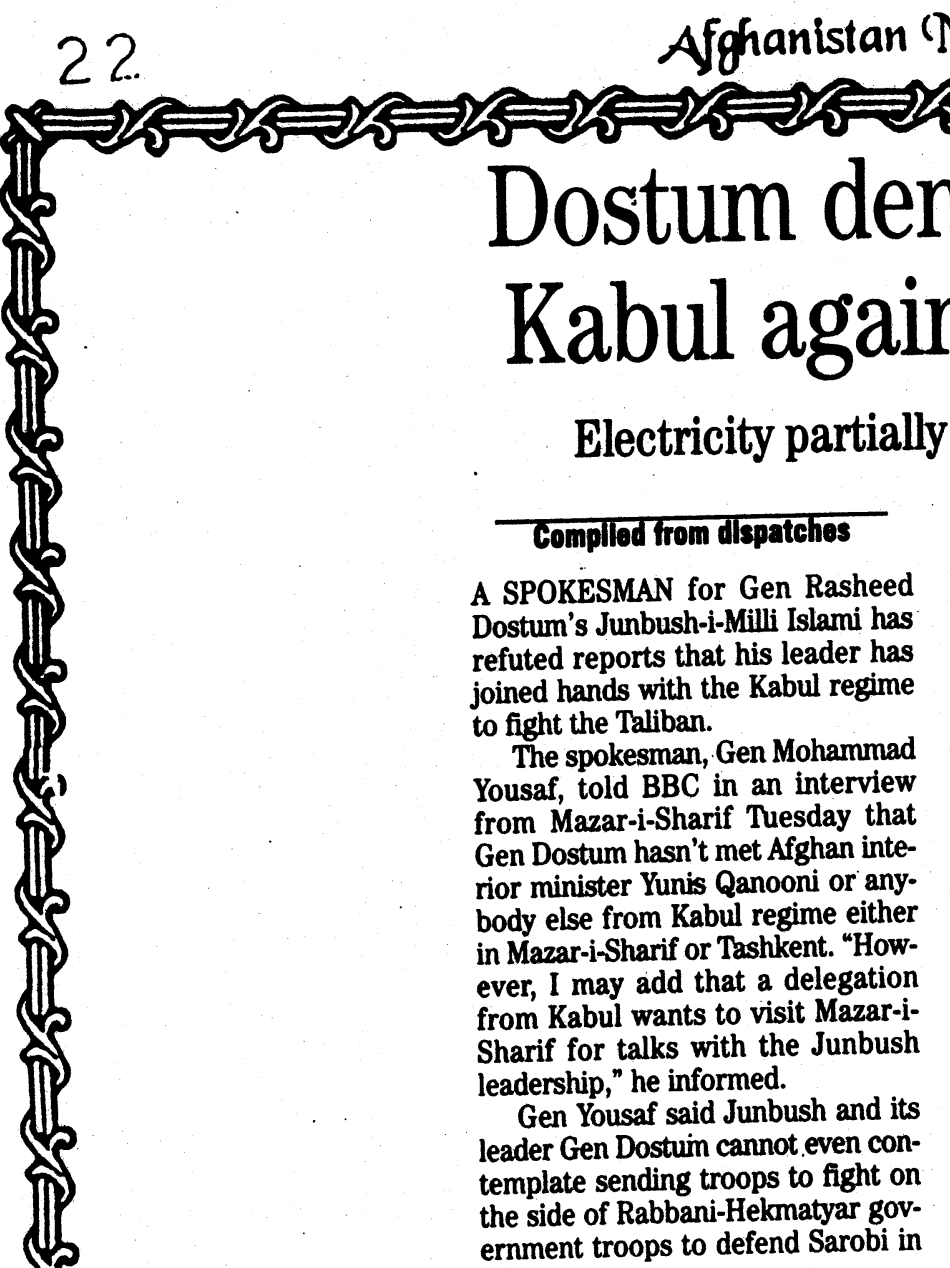

case of a Taliban attack. "We don't believe that war could lead to a solution of the Afghan problem. Then why should we involve ourselves in useless battles?" He asked.

The spokesman said Junbush-iMilli wasn't averse to talks with the Taliban or other Afghan groups in a bid to end the Afghan conflict. But he said Junbush's joining the Kabul regime or another faction wouldn't contribute to solution of the problem and restoration of peace in Afghanistan.

Saying that Taliban military successes in Jalalabad and the defeat of its opponents weren't a solution to Afghanistan's problems, 'Gen Yousaf pointed out that the people of Nangarhar province and Jalalabad had invited and welcomed the Taliban.

Continued on Page

\section{Dostum denies joining Kabul}

\section{Continued from Page}

"One cannot oppose the will of the people and that is why the Taliban are now in Jalalabad," he remarked.

Meanwhile, residents of the embattled Afghan capital Kabul heaved a collective sigh of relief Tuesday as the electric supply was partially restored after years of blackout. About one-third of Kabul had electricity restored after power transmission cables were connected to a main hydro electric dam at Sarobi east of the city.

But the restoration may be shortlived as Sarobi is the next strategic target of the Islamic militia force. The Taliban are close to Sarobi, which guards the mouth of the gorge leading to Kabul's only operating airport at Bagram.

The power supply to Kabul had been cut in January 1994 following an abortive coup mounted against President Burhanuddin Rabbani by northern warlord General Abdul Rashid Dostum and a former opposition faction, the Hezb-i-Islami of Gulbaddin Hekmatyar.

Hekmatyar this year signed a peace deal with his former foe Rabbani and became prime minister in June, enabling the government to have access to the power plants located in the Hezb stronghold of Sarobi.

Until power was restored, Kabul was believed to be the only national capital without electricity.

Although one-third of the city had been lit, residents of the remaining sections cannot expect electricity any time soon as the power system had been looted in the past four years of factional fighting.

In the meantime, the United Nations is looking to add a woman to its peace mission in Afghanistan, despite opposition from Islamic fighters who have closed girls' schools and blocked women from most jobs outside the home. A group of Afghan women met with UN officials Monday to urge the organization to defy Islamic militants and appoint a woman to the mission. SecretaryGeneral Boutros Boutros-Ghali has agreed that a woman should be named to the mission and the organization is looking for a candidate, UN spokesman Sylvana Foa said. 


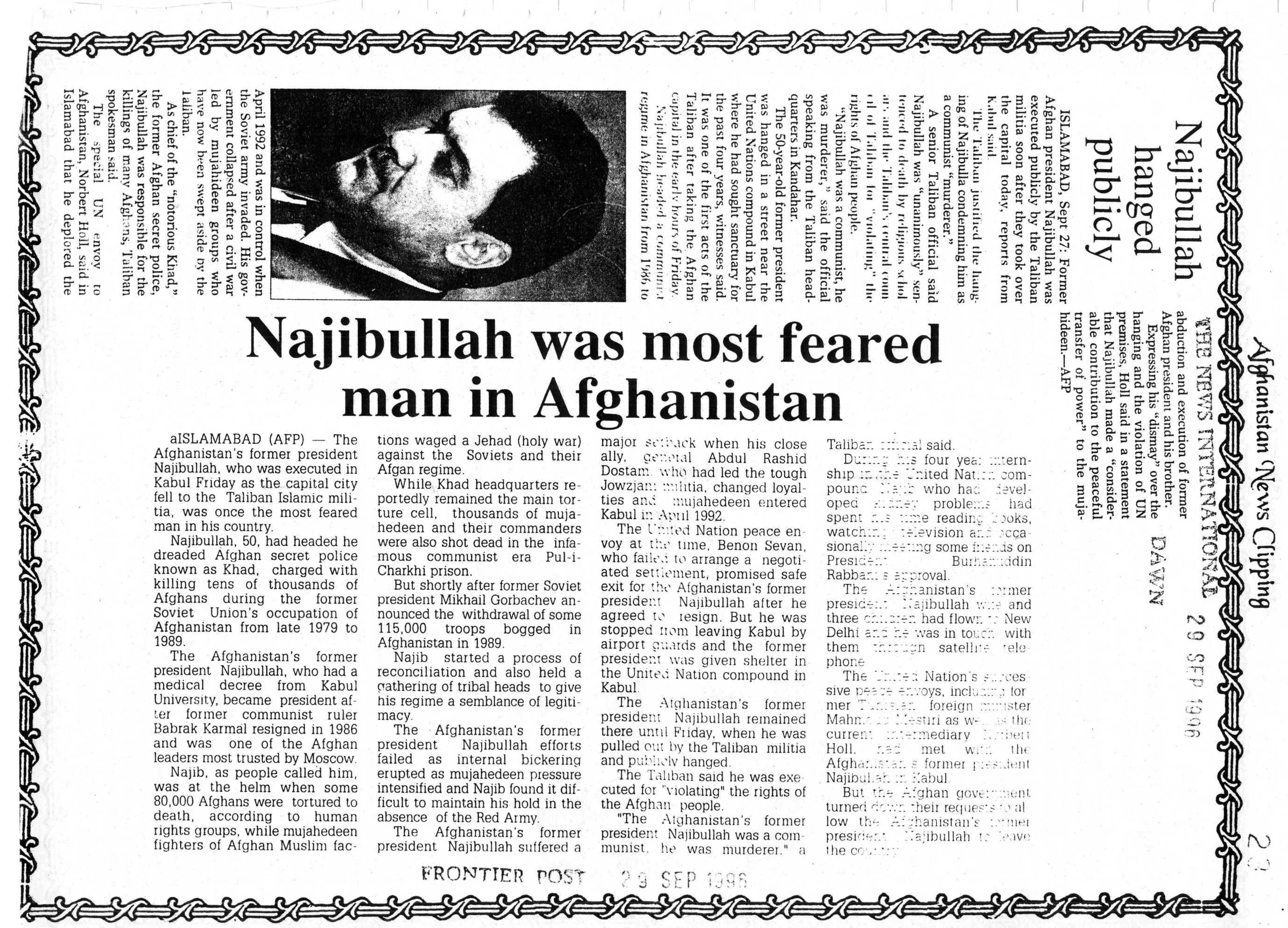




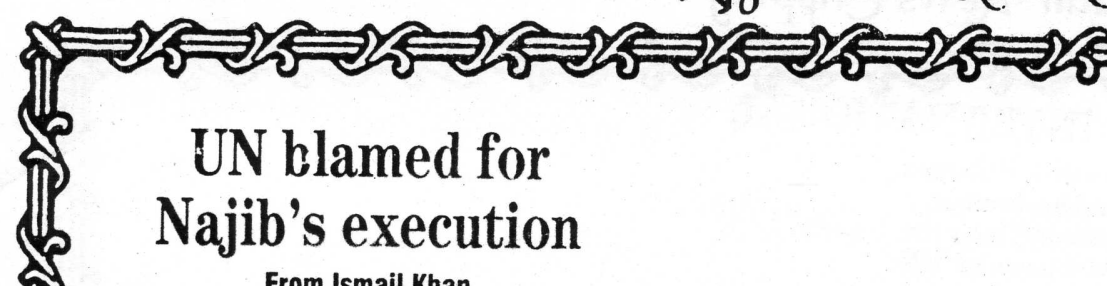

\section{From Ismail Khan}

PESHAWAR: The UN Special Mission to Afghanistan expressed dismay over the killing of former president Dr Najibullah while the Taliban proclaimed proudly of having executed the once-dreaded chief of KGB-style Afghan intelligence agency, Khad but the biggest casualty was the integrity of the world body itself. The UN has been left to lick its own wounds.

"The onus is on the UN", said a sobbing Kokay Jan, Najibullah's younger sister.

An UNSMA press release said it was dismayed over the abduction and subsequent killing by the "armed

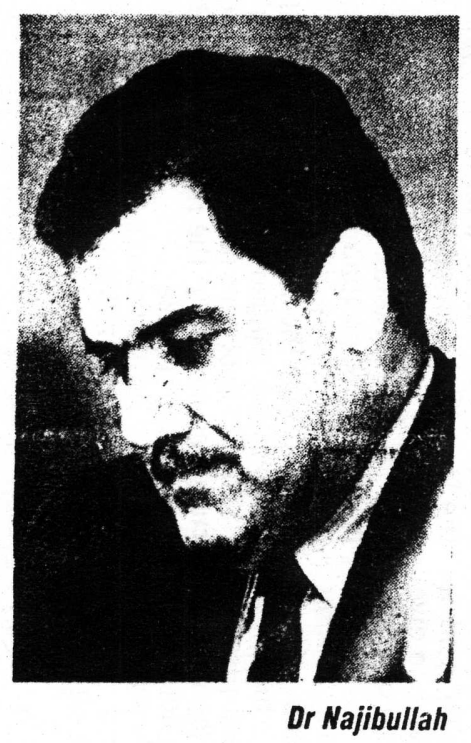

men" of the former president $\mathrm{Dr}$ Najibullah and his brother Ahmadzai in the early hours of Friday and public axpromen of therir hordioc

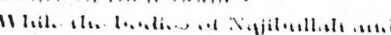
lis biother were stiung $11 \mathrm{p}$ trom a concrete traffic-control post at the gates of the presidential palace till tiling of this report, the press release though speaks of "considerable contribution towards the peaceful transfer of power" by Najibullah surprisingly contained nothing as to what has UNSMA done to retrieve the bodies.

The UNSMA director, Francis Okelo, said his office had nude a formal request to the Taliban leadership through its security officer to retrieve the bodies. "We are waiting for a reply", he said. "He deserves a decent burial", Okelo said.

Najibullah's sister, who last saw her brother holed up at the IN compound in Kabul on March 2) 1, 1996. wonders how could the UN which had guaranteed the security of his brother's life fail to carry out its commitment. "What is the UN going to tell the world. What answer has it got?" she asked. A Najibullah relation said he had called the UN a day before the students militia attacked Kabul and was assured that there was no cause for concern and Najibullah would be well-protected.

Najib called his wife Fatana Jan and three daughters in New Delhi hours before the Taliban entered the Afghan capital, Kokay informed. "He was re-assuring as ever. Don't you worry. God willing we will soon unite", he told his family. "My fate is linked with that of Afghanistan", his sister recalled of her last meeting with her brother in Kabul.

The family and Najib's fans are anguished over the UN failure to protect and provide safe passage to the expresident and his brother. His sister and cousins want their bodies back for burial, possibly in Peshawar alongside their mother, who had died in a road accident two years ago and was buried here. Will the UN deliver this time? and most of all will the Pakistan government allow the burial of one of its former sworn-enemy on its soils?

Life-Sketch of Dr Najib: Born on August 5, 1947, the burly Najibullah had completed his early education from Habibia Institute, Kabul, and later did his medical graduation from Kabul's Medical University during which time he was also the head of pro-PDPA students faction. He later became a member of the central committee of People's Democratic Party of Afghanictan hut foll viotim to Pres-

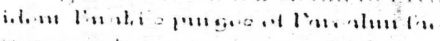

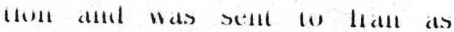
Afghanistan's ambassador. He left for Yugoslavia, however, when sacked by Hafizullah Amin's regime. He returned to Afghanistan to become director general of the dreaded Khad. followed by a brief stint as PDPA's general secretary in 1985 . He was made president of Afghanistan on November 29, 1986, the office which he held till his voluntary resignation on April 15, 199.2.

The UN guaranteed him a safe passage out of Afghanistan but he took sanctuary at the UN compound when stopped from leaving the country at the airport. He remained there for four and a half years till his execution by the Talibain on Friday morning

$$
2 \text { Q SEP } 1998
$$

\section{Nasim Wali condemns killing of Najib}

From Our Correspondent

PESHAWAR - The ANP Provincial President and opposition leader in the NWFP Assembly, Begum Nasim Wali Khan while expressing her grief and sorrow over the brutal hanging of former Afghan president Dr Najibullah and his colleagues, termed it un-Islamic, immoral and unethical.

Talking to The Nation on telephone from her Wali Bagh Charsada residence on Friday, Begum Nasim Wali Khan questioned that whether Islam allows hanging of a prisoner without providing him clarification opportunities. She said that Dr Najibullah was a prisoner in the United Nations compound from last four years and he was never given an opportunity to clarify his position before the Afghans.

Commenting on the role of United Nations, Begum Nasim Wali Khan said that it had failed to fulfil responsibilities regarding protection of Dr Najibullah. She said that United Nation's failure has become exposed before the world.

To a question, Begum Nasim Wali Khan said that former Afghan president Dr Najibullah since April 16, 1992 last was never a party in the fighting of Afghanistan, therefore, there was no justification for Taliban to kill him She said that the real parties to the fighting were Rabbani, Hekmatyar and Masud.

Begum Nasim Wali Khan said that it was impossible for Taliban to capture Kabul by their own. The Kabul regime from the last four days making complaints before the United Nations about the foreign interference in the affairs of Afghanistan. She said that with the help of foreign forces, Taliban were enabled in capturing Kabul. She asked for an end to foreign interference in affairs of Afghanistan.

\section{Namaz-i-janaza of Najib today}

From Our Correspondent

PESHAWAR - The Pukhtoonkhwa Milli Awami Party said that Ghaibana Namaz-i-Janaza of former Afghan president Dr Najibullah, his brother Ahmadzai, Gen. Jaspar and Gen. Tokhi will be held at Jinnah Park Peshawar on Saturday at $4.00 \mathrm{pm}$.

The PMAP, through its Press release called upon patriotic and democratic-minded Afghans and Pukhtoons all over the province to participate in Ghaibana Namaz-i-Janaza of late Dr Najibullah. 


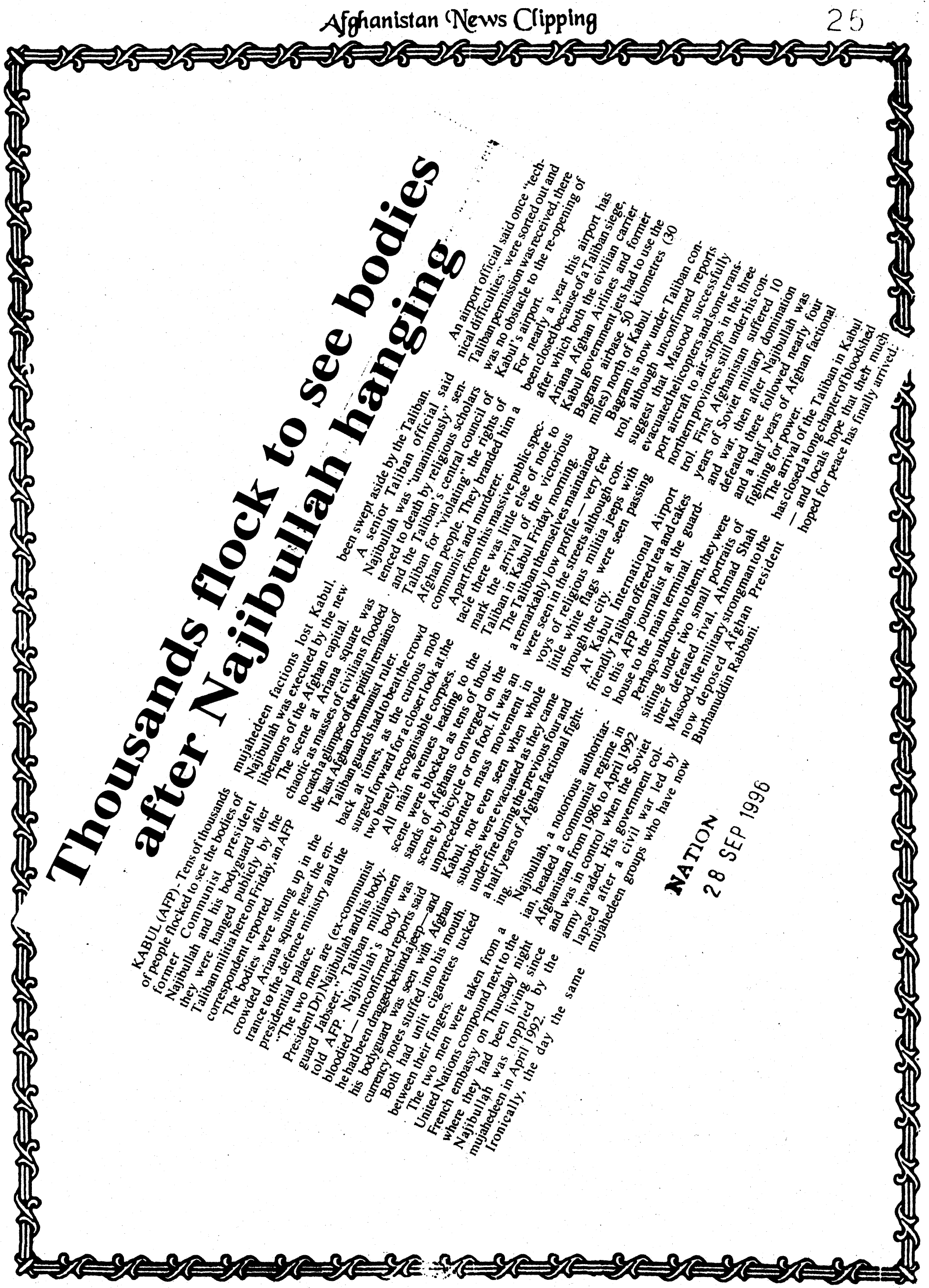


lutionary power and socio=-economic transformation in the country.

After the Saur Revolution he was also appointed to a diplomatic mission in 1978 but due to his experience and active role he became General President of the State Security Services. In 1981, he became member of the PDPA Politburo. In 1985, the 16th plenum of the PDPA Central Committee elected him Secretary of the PDPA Central Committee elected him Secretary of the Party and in the very next plenum he was elected as PDPA Secretary General.

Dr Najibullah was elected as President of the Revolutionary Council on October 1, 1987, and the traditional Loya Jirga of Afghanistan elected him as President of Afghanistan on November 30, 1987. After becoming President of Afghanistan, Dr Najibullah had declared policy of national reconciliation and had asked for a negotiated solution to the Afghan conflict. In this respect, he not only extended maximum support to the United Nations peace mission for chalking out a time table for withdrawal of former Soviet troops from Afghanistan but he also offered negotiations to all of resistance leaders. Even he had asked former King Mohammad Zahir Shah to come back to the country. However, all his efforts proved useless as the resistance leaders failed to decide at their own.

His tremendous and selfless cooperation with the UN peace mission resulted in withdrawal of former Soviet troops from Afghanistan in 1991. However, after signing of the Geneva Accord in April 1988 as well and after the withdrawal of former Soviet troops in 1991, his government had to face economic blockade as the resistance forces with help of theirforeign friends blocked all leading routes and roads. While he himself showed extra-ordinary confidence over the United $\mathrm{Na}$ tions peace mediators particularly on former envoy Benan Sevan, some of his colleagues including Gen. Abdul Rashid Dostum, Gen. Momin, Gen. Baba Jan and Syed Mansoor Nadri signed a secret agreement with warlord Ahmad Shah Masood.

Before transferring power to the jehadic leaders, Dr Najibullah was helpless before the intriguers and he handed over the power to Benan Sevan of the United Nations on April 16, 1992. Soon after handing over the power to the United Nations, he made an attempt to fly to a foreign country but soldiers loyal to Gen. Momin prevented him and he was compelled to take shelter in the UN compound on the same day. Sine April 16, 1992, he remained in the said compound and till his hanging by Taliban.

Dr Najibullah was married and had with three daughters. His wife Fatana along with three daughters had left Kabul city in March, 1992, and is still residing at Ashoka Hotel, New Delhi, India. One of his brother had defected to Ahmad Shah Masood in 1980 and he is now residing in United States of America. His mother had lost her life in a road accident at Peshawar about one year back and was buried in a local graveyard. A number of his relatives are still residing in Peshawar. His younger brother Ahmadzai was also hanged by the Taliban.

\section{Thousands attend Najib's ghaibana namaz-i-janaza}

F.P. Bureau Report

QUETTA - Thousands of people belonging to different political parties attended ghaibana Nimazi-Janaza of late Dr Najibullah, expresident of Afghanistan and his brother Shahpur Ahmadyai on the call of Pakhtoonkhwa Milli Awami Party (PMAP) here af \Sadiq Shaheed football ground on Saturday.

Those who participated in the funeral prayers included Senator Abdur Rahim. Senator Akram Shah, provincial ministers $\mathrm{Dr}$ Kaleemullah Khan, Abdul Qahar Wadan and Obaidullah Babat,
Aurangzeb Kasi of ANP, Malik Habibullah Bazai, president Balochistan Agriculture Federation, Isa Roshan, secretary general of Pakhtoonkhwa Students Organisation (PSO), Nasrullah Zarag, secretary of PSO, Sher Ali Bacha, secretary general of the PMAP and others.

Addressing the mourners, deputy chairman of the PMAP Senator Abdur Rahim Mandokhel paid rich tributes to Dr Najibullah and condenined the barbaric killing of former Afghan president by Taliban.

He said Najibullah was a martyr because a legitimate court did not award him death penalty, rather the late leader's inhuman and unIslamic hanging violated the Islamic and international laws.

Mandokhel claimed that had $\mathrm{Dr}$ Najibullah been guilty, then Talibans, who claim to be the champions of Islam, should have tried him in a court.

He said every human being would have to taste death, but to render life with honour and bravely without compromising principles adorned history. Dr Najibullah will be remembered by the future generations. 


\section{Dr Najib's execution criticised in NWFP}

\section{Bureau Report}

PESHAWAR, Sept 27: The execution of Dr Najibullah, the last president of Soviet backed Afghanistan who was hanged along with his brother and two of his confidants in Kabul on Friday morning, has caused a stir among the people of the Frontier province.

Dr Najib, it may be recalled, had roots in Peshawar since he studied here for few years. He also provided vital support to a number of politicians from this province who were in self exile in Kabul during his tenure.

Some of the prominent personalities of those days whom he provid. ed asylum included Ajmal Khattak the present president of ANP, Afrasyab Khattak, general secre tary of Pukhtoon Khwah Qaumi Party and Mehmud Khan Achakzai, MNA and chief of Pukhtoon Khwah Awami Milliparty.

Begum Nasim Wali Khan, provin cial president of the ANP in her sharp reaction on the execution of Dr Najib condemned what she termed the brutal killing of former Afghan president as an un-Islamic, immoral and un-ethical act.

In a statement from her Charsadda residence on Friday

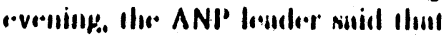

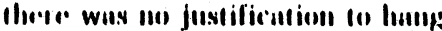
Dr Najib and his colleagues in such a "dastardly manner without giving them the opportunity to clarify their position."

"When Dr Najib was out of Afghan politics and no more a party to the power tussle after April, 1992 and had relinquished his office in favour of Mujahideen government then why he was he victimised?" she asked.

She also blamed the U.N. for failing to protect the life of ex-Afghan

DAWN 28 SEP 1995 ruler who had taken refuge in its compound since last four years. "The real party to the fighting were President Rabbani, Hekmatyar and Ahmed Shah Masood who escaped death despite fierce fighting in Kabul," she added. She opined that with the death of Dr Najib, the mbroglio of Afghanistan will not end. She also referred to the ousted Kabul regime which repeatedly alleged foreign assistance to Taliban militia without which they could not have entered Kabul, she said and warned against meddling of the foreign forces in Afghanistan affairs and advised them to stop it in the internal affairs of that country. She did not name the foreign forces. Pukhtoon Khwah Awami Milli Party also expressed his profound grief and sorrow over the execution of $\mathrm{Dr}$ Najib, his brother Saifur Ahmedzai and two of theirconfidants.

He said the Taliban had no justification in hanging Dr Najib and his associates after the announcement of general amnesty. The Taliban, he further stated, should have taken action against those who had invited Soviet troops into Afpllomistim. 管 in the installation of ex-monarch Zahir Shah but the forces who were backing Taliban did not want any hurdle in their scheme of things.

Meanwhile, Pukhtoon Khwah Awami Milli Party, NWFP announced to offer Ghaibana Namaz-i-Janaza for former Afghan president Dr Najibullah, his brother Saifur Ahmedzai and two other close aides at Jinnah Park, Peshawar on Saturday at $4.00 \mathrm{pm}$.
Arbab Mujibur Rahman, secretary

would not have created any hurdle

\section{ANP asks UN to return body of Dr Najeeb F.P. Report}

PESHAWAR - While condemning the brutal killing of former Afghan president, $\mathrm{Dr}$ Najeebullah, a veteran nationalist leader, Khan Abdul Wali Khan. along with other key office-bearers of Awami National Party, has asked the secretary-general of United Nations Organisation to adopt immediate steps for handing over the body of Najeebullah to his heirs or to ANP for his burial with full honour in Pukhtoonkhwa.

In this connection an express telegram was sent on Friday to the UN secretary general by Khan Abdul Wali Khan and other party leaders including Ajmal Khattak, central president. Dr Inayatullah Khan, secretary general, Qazi Muhammad Anwer, deputy secretary general and Begum Naseem Wali Khan, provincial chief

The telegram states that $\mathrm{Dr}$ Najeebullah Khan, ex-president of Afghanistan was in the protective custody of the UNO since last four years.

It was added that Dr Najeeb till last mornent did his best to put his country on the path of peace and prosperity and to prevent killing of Afghans under different slogans.

They said, "we the Pushtoons throughout the world, the nation-

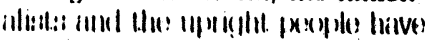
cenerved with shock the trangic news of the killing of $D_{r}$ Najeebullah Khan at the hands of the invaders of Kabul".

They asked the iNO to adopt such steps.so as to make the delivery of the dead body of Dr Najeebullah possible to his heirs or else his dead body be handed over to ANP for his burial with full honour in Pukhtoonkhwa.

FRONTIER POST

28 SEP 1996 
BY MUHAMMAD KHURSHID

PESHAWAR - The public hanging of former Afghan president Dr Najibullah by Taliban Friday, sent a wave of shock and grief and indignation across the NWFP and tribal areas.

Expressing shock over what she called the execution of Najibullah, the provincial president of Awami National Party, Begum Nasim Wali Khan blasted those elements who masterminded the hanging of this great Pakhtoon leader

Talking to The Frontier Post Priday, Begum Nasim, who is also the opposition leader in the NWFP Assembly, maintained that the execution of Dr Najib was a conspiracy against the Pakhtoon nation.

"Dr Najib is a ray of hope for millions of Pakhtoons, who have been suffering for the last 15 years due the conspiracies of antiPakhtoon elements", she added.

She went on to say that she was stunned when she heard the news that Dr Najib was hanged publicly. "I am unable to find words for condemning this ast of barbarism", she said.

The ANP leader blamed Pakistan for the killings of thousands of Afghans. "Dr Najib was hanged on behest of Pakistan", she argued.

When asked, whether, after the fall of Kabul to Taliban, peace would return to Afghanistan, she replied that Taliban could not restore peace, as according to her, it was not the policy of their masters to see this war revenged country prosper.

The ANP leader said that it was against Islamic tenets and the Pakhtoon code of ethics that a helpless and unarmed prisoner was killed so brutally.

Begum Nasim flayed the United Nations for its failure to provide security to a person who was in its custody for the last four years. "Actually it was the responsibility of the UN to ensure Dr Najib's protection", the opposition leader in the NWFP Assembly said.

A nationalist leader and the vice-chairperson of Pakistan Human Rights Commission, Afrasiab Khattak also condernned the public hanging of former Afghan president Dr Najibullah.

Talking to The Frontier Past, he said it was pathetic that Pakhtoons lost a great leader. "I condemn this act of barbarism", he said.

Khattak went on to say that it was not less than a tragedy that a great Pakhtoon leader was killed in such a brutal way. Paying tributes to the slain Pakhtoon leader Dr-Najib, he'said that he did a lot for the cause of Pakhtoons, and his name would be remembered in the history for ever.

He maintained that it was a well-hatchud conspiracy to eliminate patriotic Pakhtoon leadership, and Dr Najib was the first victim of this conspiracy.

Meanwhile, the provincial president of Pakhtoon Students Federation. Muhammad Aimal expressed his sorrow over the execution of Dr Najibullah.

In a press statement issued here Friday, he held the United Nations responsible for the hang. ing of Dr Najib, as according to him, he was a prisoner in the UN compound, so it was the responsibility of the UN to ensure his safety.
He asked the government to close all the offices of Taliban, as "they were the murderer of the great Pakhtoon leader". He threatened that if this demand was not accepted immediately. the PkSP would launch agitation.

A nationalist leader from Bajaur Agency, Noor Hakim also blasted Taliban for publicly hanging $\mathrm{Dr}$ Najib. He said that the people of tribal areas were shocked when they heard the news of Dr Najib's hanging.

The people of Peshawar were seen wailing, when they heard the news of Dr Najib's execution. They showed great resentment and indignation over this act of Taliban. They demanded of the government to withdraw its support from Taliban after this inhuman act.

Muhammäd Zarnan Khan, zonal culture secretary of the Pakhtoonkhwa Milli Awami Party, while talking to The Frontier Post strongly condemned the hanging of Dr Najib. According to him, the hanging of Dr Najib at the hands of Taliban was, as a matter of fact, a conspiracy hatched against Pakhtoon leaders.

Muhammad Zaman Khan, member central committee of Pukhtoonkhwa Students Organisation, came very hard on Taliban.

FRONTIER POST

28 SEP 1996
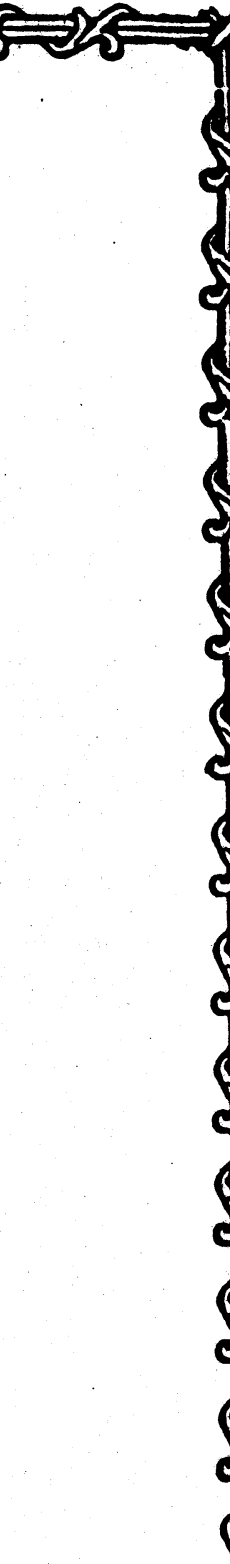


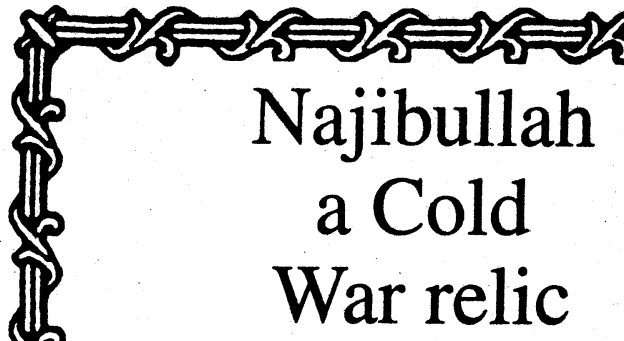

\section{By Raja Asghar}

ISLAMABAD: Afghanistan's former president Najibullah, executed in Kabul on Friday by Taliban militia after they seized the capital, was a relic of the Cold War.

The man known as the "Butcher of Kabul" for his proclivity for killing opponents, many by his own hand, was hanged and strung up from a traffic control post at the gates of the presidential palace.

Najibullah, 49, had been a virtual prisoner at a UN compound in Kabul for 4-1/2 years when he was killed along with his brother, Shahpur Ahmadzai.

In a visit to Kabul early this year, then-UN special envoy for Afghanistan Mahmoud Mestiri said he believed the former president should be allowed to go free.

"I hope some day things will be calm enough in this country that we could have Najibullah free again," he said. "He deserves to be free. I don't know if he was a good man, but he is a man of goodwill."

But that was not to be. President Burhanuddin Rabbani's government, which had spared Najibullah's life and left a decision about his fate to the future, crumbled before the latest Taliban sweep through eastern Afghanistan.

Najibullah was ousted on April 15,1992 , when Mujahideen forces closed in on Kabul after 14 years of civil war against a Soviet-backed communist government.

The United Nations says he had offered to resign as part of a peace process to pave the way for general elections.

In return, Najibullah was allowed to leave the country, but as he was driving to the airport he was stopped by Afghan army officers who had turned against him. He sought sanctuary in the UN compound, where officials felt obliged to take him in.

It was meant to be a temporary arrangement, but he remained there as a leftover of the Cold War and something of an embarrassment for both the United Nations and the Afghan government that could not agree on what to do with him.

His few visitors were from the United Nations or occasionally the Afghan government. He had not seen his wife or three daughters
DAWN 28 SEP 1996

since his ouster, but had been making regular telephone calls to them in India, fondly hoping he would join them one day.

The government said it believed it did not have the authority to release Najibullah, and that only a future government or parliament could decide his fate.

"This is a problem that the government has not created," then deputy foreign minister Abdur Rahim Ghafourzai said in April. "This is a problem the United Nations created, and it's up to the United Nations to find a solution to that problem."

It seemed nobody was willing to take responsibility for what should happen to the man.

The Rabbani government feared it could face a wave of criticism if it released Najibullah, a man whose critics say had a hand in the annihilation of hundreds of thousands during the civil war.

Najibullah was elected president for seven years in 1987 by a traditional Loya Jirga (grand assembly) he had convened in Kabul. He was a diehard communist and a protege of then Soviet President Mikhail Gorbachev.

He is credited by the United Nations for his part in the UN-brokered peace talks in Geneva under which Moscow pulled out more than 100,000 troops from Afghanistan in 1989 after a decade of fighting.

But it is his role before and after this honeymoon period that Afghans hold against Najibullah.

From late 1979 to 1985 he was head of the notorious Khad secret police that he built into a KGBstyle organisation that operated by terror.

Born in 1947 - the exact date has never been made public Najibullah was at first hampered by his relative youth in a country where respect for the wisdom of elders is a strong tradition.

Former schoolmates remember him as a devout Muslim Najibullah means "noble man of God" - although he eagerly embraced the PDPA at Kabul University.

For a while after taking office, Najibullah dropped the "ullah" from his name with its religious overtones, though he restored it when he became head of state.

Najibullah enjoyed weightlifting, swimming, tennis and other sports in his university days. He was softspoken with penetrating brown eyes, but exuded dynamism and authority.
"He has an easy charm, but can suddenly change his manner from a relaxed pleasantness to cold, steel-like suspicion," an acquaintance once said about him.

Najibullah was born into the powerful Ahmadzai clan of the Pashtun people, who make up about balf Afghanistan's population.

He was brought up in Peshawar and in Kabul, although he regarded his family home town as Gardez, capital of the eastern province of Paktia.

He attended high school in Kabul and qualified as a medical doctor in 1975 at Kabul University, where he devoted most of his student days to politics and was twice jailed.-Reuter

\section{PMAP flays hanging}

F.P. Bureau Report

QUETTA - Pashtoonkhwa Milli Awami Party (PMAP) while strongly condemning the brutal killing of former Afghanistan's president Dr Najibullah announced to offer Ghaibana Nimaz-i-Janaza of late leader in Sadiq Shaheed football ground here this afternoon.

In a press statement issued here Friday the party cancelled the Quetta Mela which was to be inaugurated here on September 30 by NWFP Chief Minister Aftab Ahmed Khan Sherpao as a mark of protest against inhuman and unIslamic killing of Dr Najibullah by the Taliban militiamen.

PMAP claimed that former Afghan president under United Nation's formulas had relinquished power to restore peace in the country and thereafter he was living in the office of United Nations in Kabul till he was eliminated by Taliban's men in the early hours of Friday.

The statement added that United Nations was also responsible for the tragic incident as it totally failed in its obligations to protect the life of former Afghan president who was under the shelter of United Nations representatives.

FRONTIER POST

28 SEP 1996 
or

N urday condemned Taliban Islamic Movement for the brutal killing of former Afghan president Dr Najibullah in Kabul and the hanging of his body in disgrace.

"What kind of Islam, morality, tradition, and Pakhtunwali Taliban plan to practice in Afghanistan. Does Islam permit dishonouring dead bodies," asked ANP provincial president Begum Nasin Wali Khan at a joint press conference with the party president Senator Ajmal Khattak in Peshawar. The ANP leaders also condemned the United Nations for its failure to protect the life of $\mathrm{Dr}$ Najib and his brother Ahmadzai.

She said that it was hardly Islamic or in accordance with the existing norms to bring out a prisoner and hang him in public without any trial. The dead bodies, Begum Nasim said should be handed over to the relatives to burry him in honour as he was an Afghan and Muslim. She blamed that certain forces were behind Taliban.

"We condemn the invasion and all those who attacked Afghanistan," said Begum Nasim Wali Khan. She said that like the past, her party con- tinue to condemn foreign interference in the affairs of that country. In reply to question, she said that Babar and all those meddling in the Afghan conflict should know that Afghans would not compromise on their freedom and loyalty to their country.

The ANP leader said credibility of Taliban statements and their future plans was questionable as $\mathrm{Dr}$ Najib was killed in a cold-blood despite the announcement of a general amnesty by the students militia. "Its inhuman, undemocratic and an open terrorism," said the ANP leader adding that she won't get the proper words to condemn the barbaric act. She said Dr Najib was the true successor of Ahmad Shah Abdali but the vested interests were able to eliminate hirn.

Begum Nasim also criticised Taliban for closing down female schools in the areas under their control and ordering women not work. She said that the steps taken by 'Taliban speak of the change and the revolution which they plan to bring in Afghanistan. Begum Nasim said that Najib should also have been set free like Rabbani, Hekmatyar, Masood and others.

Ajmal Khattak said that the ene- mies of Afghanistan were out to harm that country and its interests by killing a peace loving leader like Dr Najibullah. He said today's Afghanistan needed Najib and his wisdom for its progress and development. He said the major event of capture of Kabul was the killing of Najib and not the fall of the country capital to Taliban which he said shadowed their victory. He said those encouraging such trend should worry for their future because bad actions have always bad results.

A number of political, social , doctors, lawyers, engineers, students, human rights organisations and intellectual forums have alsó condemned the killing of Dr Najib and his brother by Taliban and demanded that the body of the late president be handed over to his relatives for burial.

Those condemning the killing include, Pukhtunkhwa Millj Awami Party, Pukhtunkhwa Qaumi Party, Pukhtun Students Federation, Malgari Doctran, National Lawyers Forum, Human Rights and Wild Life Protection Organisation and others. Pakhtunkhwa Qaumi Party also held Ghaibana Nama-i-Janaza of Dr Najib at Peshawar.

\section{Demand to hand over bodies of Dr Najib, brother to family}

\section{Bureau Roport}

PESHAWAR: Mazdoor Kisan Party (MKP) has demanded of the Taliban to hand over the bodies of former president Dr Najibullah and his brother Ahinedzai to his family so that they could be buried.

Addressing a press conference here on Saturday, president MKP Kamil Bangash condemned the murder of the lasi communist president of Afghanistan without any judicial trial. He said the killings and dishonouring the bodies was jagainst the Islamic and human norms. He said Taliban, who claim to be following Islamic laws, have in fact brought a bad name to Islam. Kamil said the hanging of the bodies in the public and disgracing them was the prove of Taliban's ignorance and barbarism.

He termed the occupation of
Kabul by Taliban and subsequent killing of Dr Najib as a conspiracy orchestrated by the US to make Iran unsecure in the region. And for this Pakistan was used to arm and organise the students militia, he added.

The MKP leader said that UN cannot be totally absolved of the murder of former president as he had relinquished power in 1992 on its insistence and guarantees. The world body had failed to protect him and to retrieve his body, he added.

He regretted that even at this hour of need the nationalist leaders stood divided and could not device a united stand. He informed that he had talked to UN director in Islamabad Francis Okelo who has assured hin that they would try to retrieve the bodies as soon as possible. 
In a press statement issued here on Priday, he paid glowing tributes to late Najibullah and declared him a true nationalist, patriotic and seasoned politician and said that his death would be a set back to all the efforts of bringing peace to Afghanistan. $\mathrm{He}$ also criticised the role of United Nations and said that $\mathrm{Dr}$ Najib was the lone Afghan leader who himself resigned his office on

the advice of the high officials of UN so as to restore peace and tranquillity in Afghanistan.

Afzal Khan regretted that when the United Nations could not safeguard its own centre then what could else expect from it. He condemned the discretion of the dead body of Najib and said that no civilised society and Islamic norm could allow such an inhuman act.

Meanwhile, some Afghan political workers represented by Mohabbat Afghan have ques. tioned the credibility of UN and said that with the brutal killing of Dr Najib the UN was completely exposed to people.

In a press release issued here on Friday, it was said that the Afghans heard the death news of Nimaz Janaza" at the Sadiq Shaheed the detained Afghan leader, Dr park on Saturday afternoon where Najib Ahmadzai with profound they paid homatge to the deceased sense of shock and grief. They Afghan leader and prayed tor his dewere of the opinion that the pro- parted soul.

tection of life of the slain Afghan A large number of tine people par. leader was sole responsibility of ticipated in the prayer for the deUN, USA and Western alliance, ceased Afghan leader. Speaking on who evacuated their diplomatic the occasion Senator Abdul Rathim missions together with families Mandokhel, Detnit. (hairman of the prior to the siege of Kabul at the Mandok, strongly condemmed the hands of Taliban. They said that kiling of Dr. Najeet and described it as a brutal murder of a capable FRONTIER POS? leader who made every possible ef29 SEP 1996 Afghanistan.

While speaking at a news confer-
nce Dr. Inayatullah, secretary general of the Awami National Party (ANP) equally blamed the United Nations Organisation for the brutal murcler of Dr. Najeeb aurd said that if the UNO could not get a fe passage and heirs.

the Afghans were mourning the was murdered in cold-blood after capturing UN headquarter at

The press release stated that the barbaric murder appeared to be a conspiracy against agairrst UN and Western alliance tained leaders for the reasons best known to them.

QUETTA: The nationalist Pashtoon parties like Awami National Party
(ANP) and Pashtoonkhawa Milli Awami l'arty (PMNP) and their aftilito the killing of former Ifghin Presihis death by a firing squad in Then

The workers of both these leading presed day on Saturday and ex: killings of Dr. Najeeb and his brother hy wearing the black arm bands and hoisting black flags on their vehicles,

(1) set Dr. Najeceb out of Kabul, then it should have done so on the Wednesday last when there was complete anarchy and uncertain situation ii Kabul and the ICRC and UNO had to evacuate 50 of there officials through a special flight.

"We consider the UN responsible for this murder and we shall communicate to them our feelings of shock and anger", he said while adding that a telegram had already been sent to Boutrous Boutrous Ghali, Secretary General of the United Nations while a delegation of the ANP would soon call on the resident representative of the UN in Islamabad. Dr Inayatullah said that the Taliban had no reason to kill Dr Najeeb. Dr. Najeeb was in the captivity of the United Nations when the force of Taliban emerged and so it was out of question that Inr. Najeet could inflict any harm to their movement.

If he was punished for lus role as tile President of Afglianistan or as the head of the Afghan intelligence, $\mathrm{KHAD}$, then why the religious elements busy in the holy war had ignored General Abdul Rasheed Dostum and others who had played the similar roles, he asked.

The ANP leader said that this action of Taliban would help those antiIslanic powers to show to the world that how much barbaric and cruel the Muslims were. It would be no service to Islam, he inferred while making an appeal to the United Nations to use its influence in the administration of Kabul to arrange the burial of Dr. Najeeb and his brother Shahpur Ahmedzai by their relatives and heirs. 
BY MOHAMMAD KHURSHID PlisiliAWAR - The Awami National Party Saturday denouksexl the treatment meted out to tormer Alghan president $\mathrm{Dr}$ Najibullah, saying that his summary exer:ution was nothing but an act of rank barbarism.

ANP ientral president $\mathrm{Ajmal}$ Khatliak llanked by party's provin$\checkmark$ cial president Bexjum Nasim Wiali Khan and other party loaders told a crowdal press conlerenke at the 16 Peshliwar Press Club that the - ANP and Pakhtoons condemned Ti) this inhuman act.

I'the ANP leader said that this if was ngainst the teaching of Islam if and Pakhtoonwali that holploss UN cotitisan! and hanged pub11 licty

IP He came very hard on the United Nations tor its failure to protest the life of former Alyhan president who took refuge in 1952 in its ollice after handing over power to the imujahideen under a UN-brokored preaco deal.

The ANP leader accused Pakistan of intertering in the in ternal allairs of Atghanistan but said the dream of rulors in Pakistan would not be inaterialised as the people of Afghanistan were never subjugated by the foreign powers. "This is foolish drum of the Pakistani rulers to make Afghanistan as Weir colony", he added.

While condemning this bruta act of hanging Najib publicly Beyum Nasim Wali Khan said
"Loday the whole Pakhtoon nation in in a state of shock as they never expect such type of barbarism as the Taliban are also Pakhtoons".

Was this the teaching of Islam to murder a helploss man in such a brutal way and then disyrareed his body?, he posed a question The body of lormer president should be handod over to either to his relatives or to the ANP for burial" she demanded.

Begum Nasim urged the Inital Nations to play its role in handing over the body of the slain Alukan leader to his relatives for burial. She llayed the UN for its tivilure to protect Dr Najib as he was living in its compound for luur years. She expressed pessimism
when asked whether after the fall of Kabul to Taliban peace would be restored in Afghanistan. Afghan can Alghanistan so I can say with confident the chance of peace in Afghanistan is very dim despite "aliban victory", she added.

The ANP leader said that the same fate was waiting for other Atghan leaders as Taliban were very uncivilised people so they would also put the other leaders to death.

She sairl that Taliban after the Capture of Kabul ordered the clostire of girl schools adding that getting education was the obliyation of both the men and womenl in Islain. "Our holy prophet asked both men and women to get education", she added.
The yovernment of Pakistan was providing education to the girls but supporting such type of government in Alghanistan which was against the women educa tion, the ANP leader wondered.

She alleyed that interior minister Nasirullah Babar was the di rector of what she called the dra ma being played on the soil of Alghanistan. She warned the in terior ministor to stop poking noose in the internal affoirs of Alghanistan saying that the people of Alghanistan would peolorgive him and they would tak revenge of the clostruction of their revenge

The ANP leader informed the newsinen that the ANP had not yet receiverl reply from tho Unital Nations It may be mentioned hore that ANP lender Khan Alulul Whli UN ashing it sent a letter to the UN asking it to play its role in hiulng over the body of the slain Alghan leader to his relatives. We are still waiting for the reply rom the UN", she sair.

She said that it was a tragedy thiat a gleat Pikkhtoon leador was killed in such a way. According to her, Pakistan could be held re sironsible for the murder of Najib. When askexi that why the ANP and other nationalist leaders remained silents for lour years when Dr ir jilb was living in the UN of tice as prisoller, Ajmal Khattak said that his party did a lot to ensture that tho former prosidont was treed by the mujahichen but risl take crexlit lor this.

\section{un-Islamic, immoral'}

From Our Correspondent

PESHAWAR - The people from every walk of life have expressed deep concern over the assassination of former Afghan president DrNajibullah immoral. In separate Press unethical and they also demanded of UNO to fulfil its responsibilities and hand to fulfi body of the former Afghan president to the bereaved family for burial

The Malgari Doctoron, in a Press nation on nation of Dr Najib and his brother and termed it dangerous for peace in the region. It said that it was the duty of UNO and particularly of USA to evacuate Dr Najib, who was in their custody to safe place during the evacuation of its staff from the Kabul but, it alleged that UNO totally failed to fulfil its duty.

The Malgari Doctoron also arranged Quran Khwani, in Doctors Hostel, on September 29, at $8 \mathrm{pm}$ for the departed soul of slain Dr Najib.

Central President of Pakistan Workers Confederation Gul Rehman said that Dr Najib, his brother and other colleagues were publically hanged without any trail which was a clear violation of human rights as well as against the Islami system

He demanded of the UNO, SAARC countries and Muslim Ummah to take serious notice of this illegal, inhuman and un-Islamic action of the Taliban. The Central leader of Qaumi Inqilabi

NATION

29 SEP 1996 UNO.

ERONTIER POST

29 SEP 1996

Party Mohammad Naeem Khan condemned the brutal murder of DrNajeeb his brother and other colleagues and termed UNO, Pakistan and foreign missionaries, Taliban and Mujahideen responsible for it.

He said that Dr Najib had resigned on the request of UNO and took refugee in UNO compound, so safe evacuation was the prime duty of UNO but failure in this case was shamful for

He said that the so-called Islami Mujahideen were exposed to the world that they were power hungry and foreign agents. He demanded of the international community to impose inertions against Taliban and continued boycott till they handover the murderer of Dr Najib and his colleagurderer of Dr Najib and his colleagues. Prominent social worker and Pukhtoon leader Babu Fazle Khaliq while expressing deep concern over the brutal assassination of Dr Najib demanded to immediately hand over the body of former Afghan president and his colleagues to the heirs for

President of ANP Mamu Banda, District Hangu, Hassan Malik condemned the assassination of former Afghan president Dr Najib and his colleagues and said that he was martyred by the American Agent Taliban in order to pave way for the retum anor American He Amanded to igent Zahir Shah. Her the colleagues to the of DrNajib and his leagues to the bereaved family. 


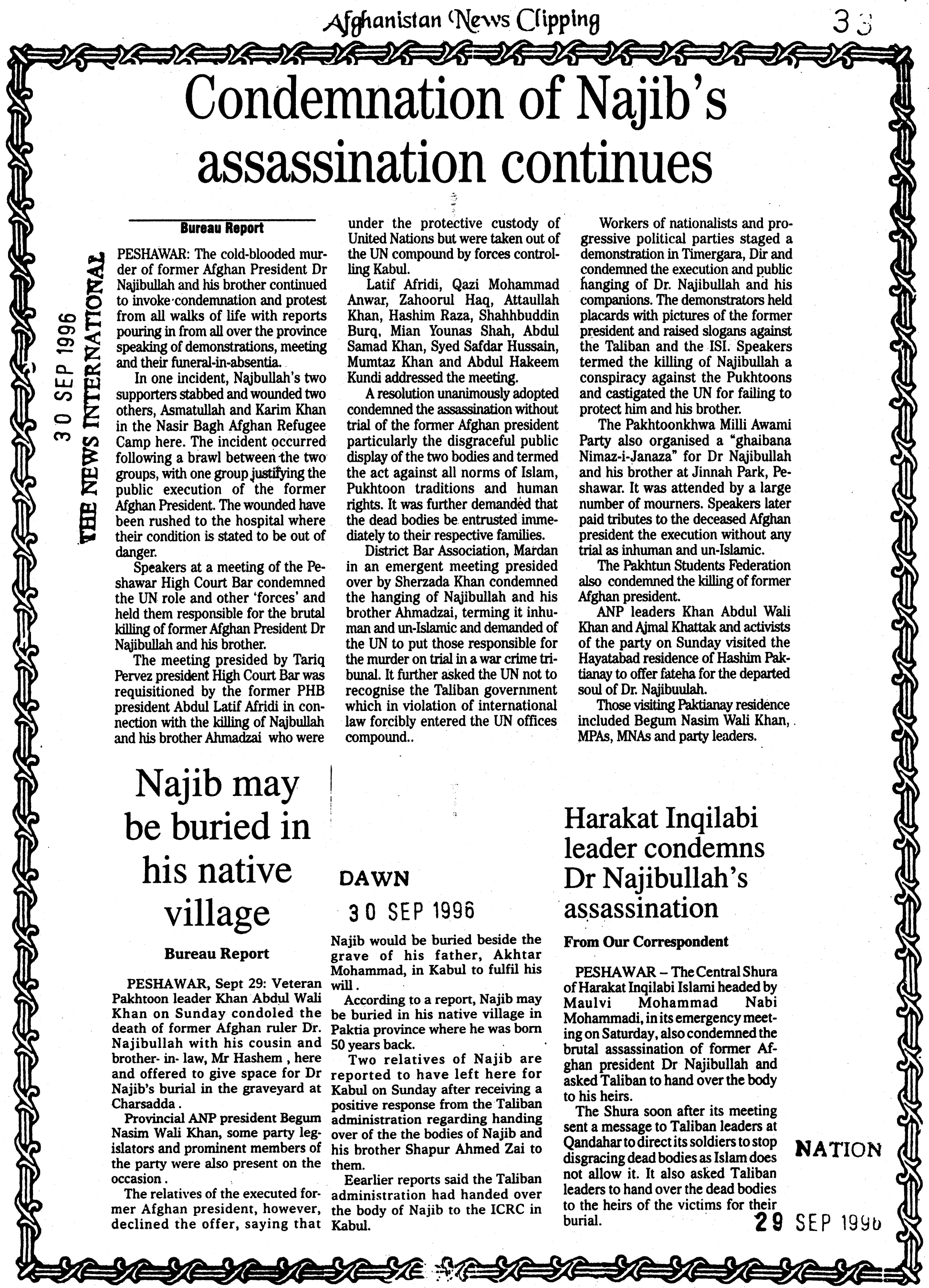


F.P. Bureau Report

QUETTA - Senior doctors in Civil Hospital Quetta and six students organisations in Balochistan Umiversity have held separate condolence meetings demanding of the United Nations secretary general that the murders of ex-Afghan President Dr Najibullah should be tried in the International Court of Justice (ICJ) to provide justice to the bereaved family.

The doctors community meeting was attended by Dr Kaleemullah Khan minister for S\&GAD, Dr Mahmood Raza former principal Bolan Medical College, Dr Hashim Bazai, Dr Aslam Baloch, Fayyaz Hashimi Baloch, Dr Shah Mohammad Merri, Dr Abdul Malik Achakzai, Dr Ghulam Gailani and others

Baloch Students Organisation (PSO-Hayee) Pashtookhwa Students Organisation (PSO), Pashtoon Students Federation (PkSF), Baloch Students Organisation (BSO-Mengal), Hazara Students Federation (HSF) and National Students Congress (NSC) held meeting at university auditorium. Mansoor Baloch. Isa Rushan, Aminullah Kakar, Sana Baloch, Ayub Chengazai and Adil Watanyar addressed the largely attended mourners.

Speakers in the condolence meetings paid rich tributes to former Afghan president Dr Najibullah for his peaceful efforts to put Afghanistan on the path of piogress and prosperity.

They strongly condemned the barbaric killing of late leader in the darkness of night and described this as shameful act which negate the Islamic and international laws.

Speakers said that the policies of Taliban leadership would put Afghanistan towards backward instead of to enter the twenty one century and particularly criticised to impose ban on the education of women.

The meetings adopted resolutions calling on the United Nations to recover the dead body of late leader for burial and demanded of the international organisation that the murderers of Dr Najibullah should be tried in the International Court of Justice to award exemplary punishment to the criminals for killing him without giving chance to defend himself against the alleged charges in an open court which was the basic requirements of the Islamic and international laws.

The students in the university and colleges boycotted the classes and the ongoing examinations of the university papers were cancelled as mark of protest to condemn the killing of Dr Najibullah

Ali Hazrat Bacha adds from BatkhelaVarious political and social organisations here have strongly reacted to the brutal killings and humiliation of dead body of the former Afghan President Dr Najib Ullah.

Besides, others political figures the Human Rights Protection Committee (HRPC) Malakand Agency, Malakand District Bar Association at Batkhela in their different protest meetings have condemned the role of the United Nations regarding the protection of $\mathrm{Dr}$ Najib. The meetings were largely attended by the social workers and lawyers to lodge their protest against the UNO and Taliban Militia for killings and humiliation the death bodies of Dr Najib and his brother Shah Poor Ahmed Zai. The organisations termed it clear violation of the human rights and appealed to all the sister organisations to raise the issue on their formers. It was also said that killing of Dr Najib was against Islam and held the UNO responsible for the brutal assassination.

Meanwhile, the participations prayed to the Almighty Allah to rest the departed souls in eternal peace and grant courage to the bereaved family to bear this loss.According to another report Pakistan Mazdoor Kissan Party Sunday criticised the hanging of four Afghan Wattan Party leaders including its president Najibullah in Kabul and said it was the most inhuman, un-Islamic and ignorant action of the executors. In a statement after meeting of office-bearers of Sindh PMKP in Karachi on Sunday the party president Fatehyab Ali Khan said that executors forgot that in 1992 Najibullah voluntarily stepped down from the Afghan presidency.

He said the executors in the opinion of the PMKP represent not only religious bigotry but it could hardly be justified under principles of Islam itself. They forgot that after the conquest of Makkah even our Holy Prophet declared the house of Abu Sufyan as house of peace for people who took shelter there, but the executors took out the four people from the safe heaven of the United Nations compound in Kabul.

Fatehyab Ali Khan called upon the UN Mission in Kabul to stop further executions and ensure that the bodies of executed Afghan leaders be handed over to their dear ones.

Meanwhile, expressing grave concern over the brutal killings of Dr Najibullah his brother and security men at the hands of Taliban, the ANP and PMAP local leaders and members of provincial assembly de plored the inhuman attitude of Taliban and termed it against the teaching of Islam. In a separate press statements issued here on Sunday. Haji Rehman Ullah, ANP district president, Dr Muhammad Saleem MPA, Asmat Ullah MPA, Muhammad Aneem Khan senior vice president of ANP and Subhanullah, divisional vice president of Pukhtoon Students Federation while condemning the brutal killings of former Afghan president have criticised the UN for failing in protecting the life of Dr Najib.

They said that those having lust for power, used Islam as a tool in their power game and ruthlessly ex ecuted the ex-Afghan president which was against all the norms of Islam and international law.

"The power hungry Taliban will not maintain their hold over Kabul for a long time and they will be up rooted in the near future from the Afghan capital they added. 


\section{Taliban take strategic town after bloody fighting}

ISLAMABAD (AFP) - The Taliban Islamic militia claimed Friday to have captured the strategically important eastern Afghan town of Azra after heavy fighting with Kabul government forces.

"Azra is in complete control of Taliban," Taliban spokesman, Ahmed Jan was quoted by the mujahedeen-run Afghan Islamic Press (AIP) agency as saying.

No independent confirmation was immediately available for the Taliban claim

AIP said the town fell early Friday after heavy overnight fighting in which 20 government soldiers were killed and another 10 were taken prisoner

Jan told AIP that the Islamic student-led militia launched a "major offensive" on Afghan government forces in Azra, a district centre in eastern Logar province late Thursday.

The Taliban used heavy weapons in the attack, the spokesman said adding that at least two pro-government commanders were also captured in the fighting.
He put the Taliban losses at three dead and five wounded.

Azra controls northern access to the eastern Afghan highway which links Kabul with the Pakistan border. ?

The town was reportedly defended by fighters belonging to the Ahmadzai tribe loyal to Hezb-i-Islami of Afghan Prime Minister Gulbuddin Hekmatyar.

The Taliban have held a number of hills around Azra since early 1995 when the religious militia first marched into the area.

An Afghan defence ministry spokesman last week denied speculation in the Pakistani border city of Peshawar that the Taliban overan Azra after capturing a nearby government base.

He said the Taliban had started shelling the government positions in Azra "but we control all key points."

AIP quoting sources in eastern Jalalabad city said the government had rushed fresh troops from nearby Tahzeen base and from Hekmatyar's stronghold of
Sarobi, 75 kilometres (46 miles) east of Kabul, to flush out the Taliban from Azra.

In Jalalabad, the neutral administration led by Haji Abdul Qadeer has also beefed up defences of its western flank to foil any Taliban incursion into the Ningarhar province.

Qadeer's. Ningarhar Shoora (council) has so far remained neutral in the governmentTaliban fighting.

The Taliban militia has been besieging Kabul from three sides for almost ten months in a bid to topple President Burhanuddin Rabbani and enforce Islamic law across the war ravaged country.

Sources in Peshawar said the religious movement's next target could be Sarobi, an important town on the Kabul-Jalalabad highway.

Analysts said if the Taliban capture Sarobi they could cut the main artery of supply to the Afghan capital and also seize control of two hydro-electric dams in the area supplying electricity to Kabul.

\section{Taliban capture Hezb-i-Islami post in Wazi}

\section{From our correspondent}

MIRAMSHAH: Taliban have succeeded in capturing tehsil Wazi post of Hezb-i-Islami commander Jalil in Paktia province, reports from across the border said.

A large quantity of arms and ammunition was also seized by the Taliban. However, there were no reports about any casualties. This is the third success of Taliban in a week's time with Tehsil Dargai in Khost and
Tehsil Zerwak in Paktika province being the earlier two.

In the recent success, the Taliban seized two tanks, four armoured personnel carriers and 20 truckloads of weapons. This post was a big weapons depot of Commander Jalil alias Khalili.

The people of Wazi have expressed their pleasure over the Taliban takeover. They hoped the change would bring peace and proc perity to the area.

THE NEWS INTEP NATIONAL

$$
085 ? 1996
$$

\section{Taliban claim capture of another district}

ISLAMABAD, Sept 6: Taliban said on Friday it had captured a strategic eastern district, dealing a new blow to President Burhanuddin Rabbani's beleaguered government in Kabul.

A Taliban spokesman in Peshawar, quoted by a private Afghan news service, said Logar province's Azra district, southeast of Kabul, had fallen early on Friday after overnight fighting.

Taliban forces now control all of Azra district including its central town of the same name, the Afghan Islamic Press (AIP) quoted spokesman Maulvi Ahmad Jan as saying.

There was no independent confirmation of the report.

AIP said the government had sent reinforcements to the area on Thursday night and on Friday from Kabul-Reuter/DPA 


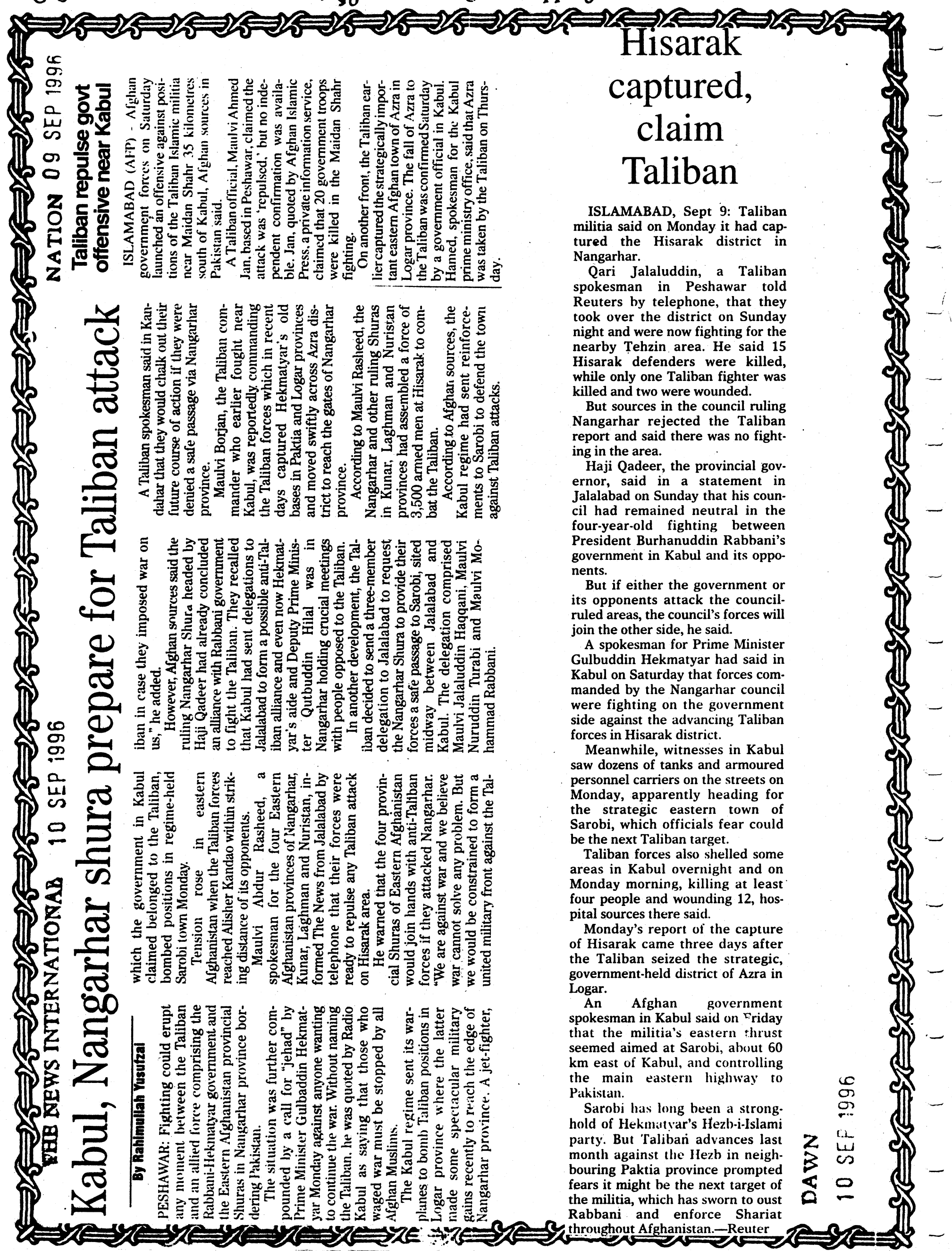




\section{From Ismail Khan}

PESHAWAR: The Taliban in a blitzkrieg offensive on Tuesday marched triumphantly towards Jalalabad, capital of eastern Nangrahar province, making its fall imminent, with fleeing to Pakistan of its Governor and several other key leaders of the eastern Nangrahar shura, security officials said.

Governor Qadeer and his commander of Khugiani district, Commander Zaman, crossed over into Pakistani border town of Torkham between $6.30 \mathrm{pm}$ and $7.00 \mathrm{pm}$ while other key members of the Nangrahar shura fled their way either to Kabul or to the Mohmand side of Afghanistan, leaving Jalalabad leaderless. A security official said one of Qadeer's sons, Jamal, who sustained injuries during fighting with Taliban at Hisarak district has also been moved to a hospital in Pakistan.

The easy sweep for the Taliban though surprising, resistance of the eastern shura forces began showing signs of crumbling after Commander Daud, a cousin of Haji Qadeer, defected to the Taliban, and surrendered Hisarak district. Heavy fighting ensued at around 10 in the morning followed by a lull in the afternoon.

Things, however, began to turn ominous for Qadeer when residents of Khugiani district, some fifty $\mathrm{km}$ from Jalalabad, raised white flags signalling their surrender to the Taliban. Security officials now place the students militia somewhere near village Tutu-Mamla. "Jalalabad's fall is very imminent. It is now only a matter of time", commented one security official who attributed the anticipated fall of neighbouring Nangrahar province to 'collective panic' among the shura members of the impending Taliban

\section{SEP 1996}

onslaught. There are also reports of defections in Jalalabad with Commander Engr. Mahmood, a shura member, siding with Taliban.

Taliban spokesman in Qandahar, Wakil Ahmad said the students militia had intended to take on government-controlled Sarobi, laying halfway between Jalalabad and Kabul on the main highway linking Pakistan but were forced to fight the eastern shura for having taken sides with Kabul. "All their tall claims of neutrality was a farce and a big lie", Wakil told The News on phone from Qandahar.

Jalalabad has always prided itself with being a peace-heaven and neutrality in the war-ravaged Afghanistan and played host to a number of meetings between rival mujahideen leaders. It has of late been home to the UN Peace Mission for Afghanistan. The UN asked its staff to make precautionary arrangements for evacuation from Jalalabad.

Nangrahar ruled with the sevenparty mujahideen shura ever since its peaceful surrender to the mujahideen following the collapse of Communist regime in April 1992, would become the 17th province to come under the Taliban control.

Officials believe the real battle, however, would begin at Sarobi, some $60 \mathrm{~km}$ east of Kabul, in a few days time where govt troops have established their frontlines between Jandalak and Tizeen. These sources said, the Taliban after taking care of Nangrahar are expected to march towards Sarobi in a day or two and would set their eyes on Kunar, Laghman and Kapisa to find access to Panjshir, home to Commander Masood.

\section{Taliban claim capture of key Afghan town}

ISLAMABAD (AFP) - The Taliban Islamic militia claimed Friday to have captured the strategically important eastern Afghan town of Azra after heavy fighting with Kabul government forces.

"Azra is in complete control of Taliban," Taliban spokesman, Ahmed Jan was quoted by the mujahedeen-run Afghan Islamic Press (AIP) agency as saying.

Noindependent confirmation was immediately available for the Taliban claim.

AIP said the town fell early Friday after heavy overnight fighting in which 20 government soldiers were killed and another 10 were taken prisoner.

Jan told AIP that the Islamic student-led militia launched a "major offensive" on Afghan government forces in Azra, a district centre in eastern Logar province late Thursday.

The Taliban used heavy weapons in the attack, the spokesman said adding that at least two pro-government commanders were also captured in the fighting.

He put the Taliban losses at three dead and five wounded.

Azra controls northern access to the eastern Afghan highway which links Kabul with the Pakistan border.

The town was reportedly defended by fighters belonging to the Ahmadzai tribe loyal to Hezb-iIslami of Afghan Prime Minister Gulbuddin Hekmatyar.

The Taliban have held a number of hills around Azra since early 1995 when the religious militia first marched into the area.
ERONTIER POST 10 SEP 1996

Taliban jet pounds Sarobi

KABUL (AFP) -..-A jet believed to belong to the Taliban militia bombed Prime Minister Gulbuddin Hekmatyar's eastern stronghold of Sarobi Monday but no casualties were reported, a government spokesman said.

"The jet was unidentified but we suspect it was flown by a Taliban pilot," spokesman for the prime minister's office, Hamed (eds:one name) said.

The jet pounded Sarobi, located about 75 kilometres (46 miles) east of Kabul in the early afternoon, the spokesiman said.

The Taliban have declared that
Sarobi is their next military objective, and not the Nangrahar provincial capital of Jalalabad further east near the Pakistani border. Hamed said.

Sarobi is an important base of Hekmatyar's Hezb-i-Islami faction.

"The Taliban have asked Haji Qadir to allow them to transit Nangrahar in order to attack Sarobi," he observed.

Qadir is the head of the shoora or ruling council of Jalalabad which has sent reinforcements to Hisarak district in western Nangrahar province to block any Taliban advance. 


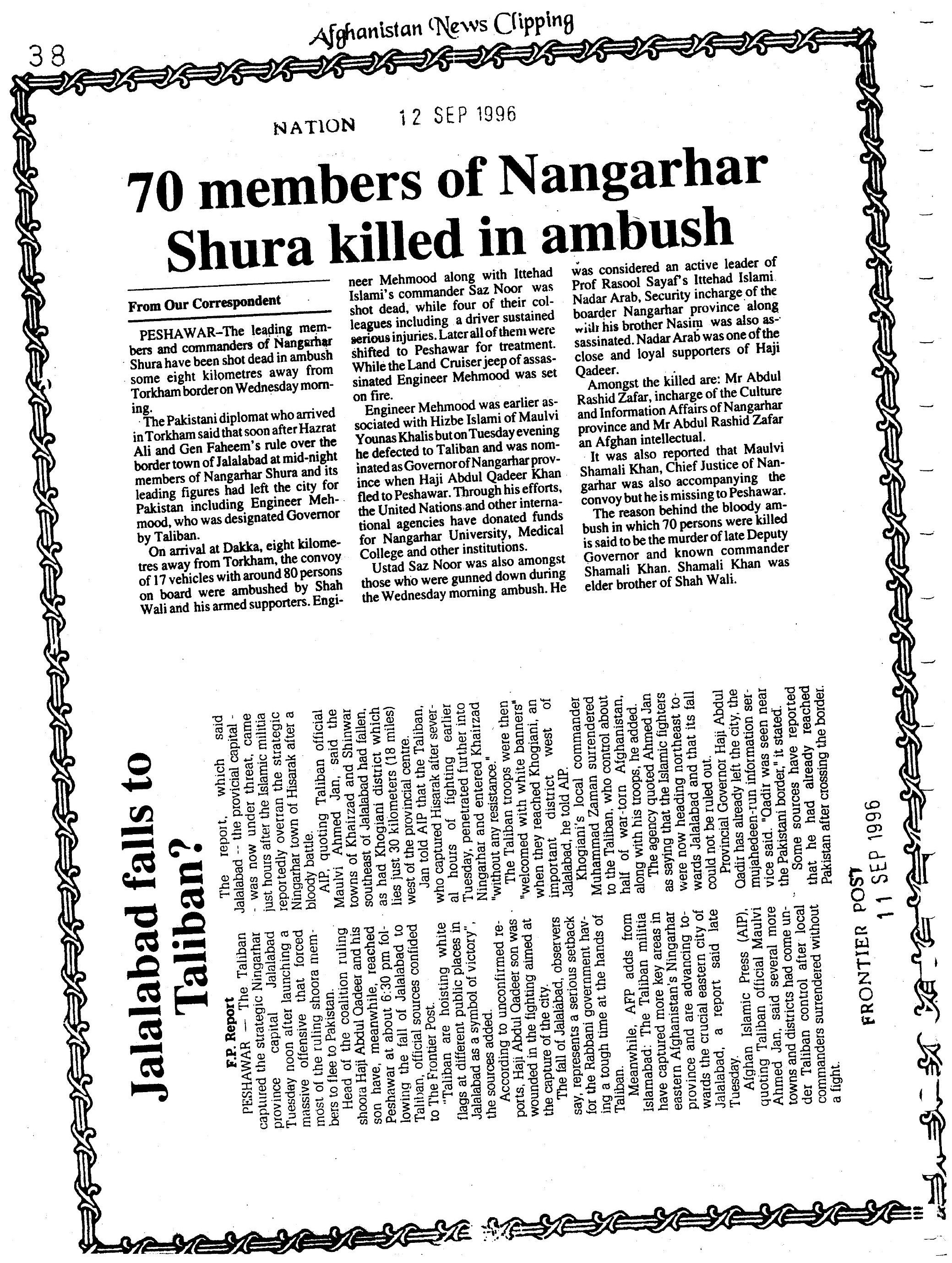


Torkham border closed; Pak consulate staff evacuated; Kabul accuses Pakistan ' of supporting student militia; new Nangrahar governor, two commanders killed?

s

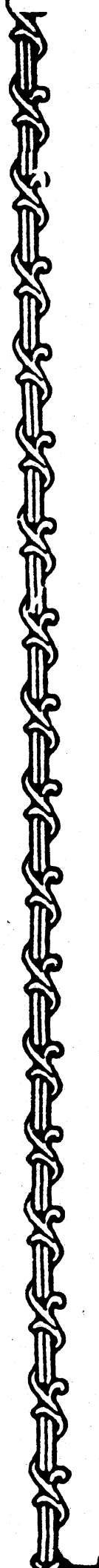

\section{From Ismail Khan}

TORKHAM: Taliban Wednesday evening moved into Jalalabad, capital of eastern Nangrahar province, bordering Pakistan, taking effective control of the city after an hour long encounter with troops loyal to President Rabbani near Darwanta.

"With the blessing of Allah we are in full control of Jalalabad and the airbase. We will enforce Shariah and restore peace. We will support the oppressed", Taliban Commander Mulla Borjan who now commands the situation in Jalalabad told The News. The Taliban are now largely in control of the Nangrahar province. the 17 th to fall to them.

There was a real drama unfolding with every passing minute for the most part of the day. Hazrat Ali, commander of the Jalalabad airbase affiliated with the Hezb-i-Islami (Khalis) who had defected to Kabul was flown back to Jalalabad from Sarobi with re-enforcements. He was dethroned hours after claiming full control of the city as Taliban-designate Governor Engr. Mahmood who had defected to the students militia a day earlier was killed in an ambush along with two other top commanders, Ustad Saznoor and Nadir Arab and 67 of their bodyguards near Dacca, about $8 \mathrm{~km}$ from here.

Jalalabad's Corps Commander, Fazl-i-Haq Mujahid who was among the ten lucky people who escaped the bloody ambush and reached the Pakistani checkpost at Shilman blamed NIFA commander Shah W' for the carnage who he said wal:

to avenge the killing of his brother Commander Shumali about two years ago. "They just pulled us out and started shooting", Mujahid said.

Coinciding with the take over of Jalalabad by the Taliban came a

statement by its now-former Governor Haji Qadeer who said he had 'resigned' his office as in his words peace and neutrality of Jalalabad was at stake. "I was not prepared to let the area turn into a battle field amongst various groups and let Jalalabad loose its peace and neutrality". claimed Qadeer who fled to Pakistan via Torkham on Tuesday evening long before Taliban moved into the city.

Earlier, reports said Kabul had brought in two thousand troops from Sarobi to Dar. fence Minister Wahidullah Sabaoon and Security Chief Gen. Fahim directly incharge of the operation. Security officials here however, later put the total figure of Kabul troops at around eight hundred.

The Taliban said Kabul's man in Jalalabad, Hazrat Ali later fled to his native Kishmand near Kunar after they moved into Jalalabad from Khugiani district.

The Taliban's mopping up operation towards Torkham concluded at $8.00 \mathrm{pm}$ when the militia took over the border posts from a handful of Qadeer's men, clearing on the way all checkposts and putting their own men incharge. A Taliban spokesman said Mulla Mohammad Rabbani has been named Nangrahar's patron adding that no decision has yet been made regarding the appointment of a new governor.

Jalalabad city itself wore a deserted look as people fearing fighting between the Taliban and pro-Kabul forces confined themselves to their homes and hearths. All markets were closed with no traffic on the road.

"We could not sleep all night. Qadeer's men kept lying to us about the whereabouts his whereabouts", said Nisar Ali Khan, Pakistan's third secretary who evacuated to Pakistan along with seven other of the officials. "The Consulate has been closed for a while", Pakistani Consul General Shafiullah Shinwari informed.

Nisar said the Pakistani was stopped twice by Hazrat Ali and his men in Jalalabad but were allowed to go after searching their luggage. He quoted Iranian diplomats as saying that they were awaiting orders from Tehran. While 14 staff members of the UN peace mission in Afghanistan remained crammed in a room unable to fly out of Jalalabad in plane which kept waiting for them at the nearby airbase, he said.

Fears of an impending fighting between the Taliban and the proKabul troops sent hundreds of people, mainly women and children, fleeing to Pakistan waiting to be be allowed to cross-over. Commandant Khyber Rifles, Col. Malik Naeem whose men were in control of the Pak-Afghan border at Torkham said an additional 250-300 troops to beef-up security and stop hundreds of Taliban from crossing over into Afghanistan.

The Pakistani border has been sealed off since $10.00 \mathrm{pm}$ Tuesday but there were reports of around 500 Taliban sneaking through the borders using unfrequented routes near Shalman and Chura Valley. It was only in the afternoon that the border authorities agreed to let food convoys cross either sides of the border.

AFP in its report from Kabul said that the Afghan government has blamed Pakistan for supporting Taliban attack on Jalalabad.

Kabul government spokesman Amrullah in a strongly worded protest note said Pakistan had hatched a "conspiracy" for their Taliban "puppets" to wage war in Jalalabad.

He said the Taliban attacked Jalalabad from two directions via the southwestern district of Surkhrod and from Pakistan via the Torkham border post.

Amrullah said pro-Kabul jet raids had been launched against Taliban "supply routes" but that the city had not been bombed "even though we know which buildings they (Taliban) occupy."

Analysts said the Kabul government was unable to secure a strong foothold in Jalalabad, despite an early Wednesday morning arrival in he city, well in advance of the Taliban.

Jalalabad airport, which the government ed was being used Wednestisi, inorning for ferrying in ammunition, is apparently now in the hands of the Taliban.

It now seems that when the coalition of pro-Kabul troops entered Jalalabad they did not occupy all the strategic buildings and locations nor establish a tight defensive security belt.

There was no news of a Kabul government counter-offensive against the Taliban-occupied areas elsewhere in Nangarhar province.

Amrullah said the "Pakistanbacked" fighting in Jalalabad would undermine the peace process in Afghanistan and "worsen relations" between Kabul and Islamabad.

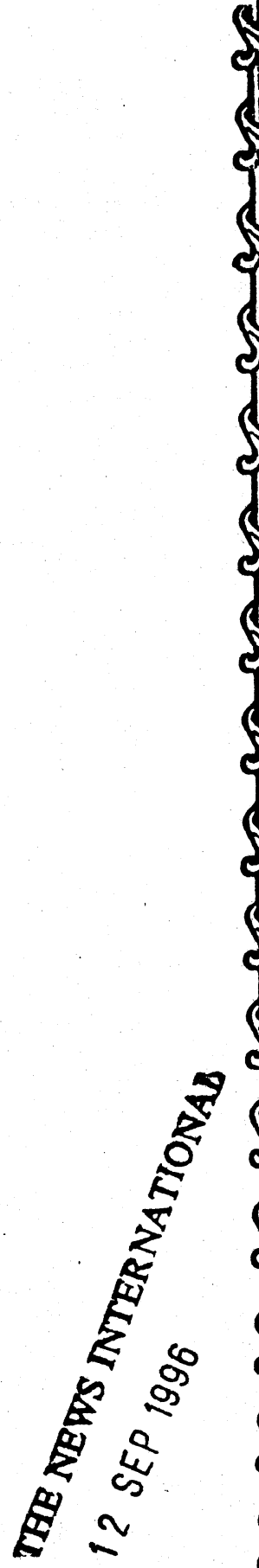




\section{Face resistance from pro-govt troops}

\section{From Ismail Than}

JALALABAD: Bolstered by a moral boosting victory in Jalalabad, capital of Afghanistan's eastern province, the Taliban on Thursday launched a three-pronged attack on neighboring Kunar and Laghman provinces and pushed their forces further down the road to Sarobi.

Over-running resistance from pro-Kabul troops at Darwanta and Besud to the west of Kabul in the morning, the students militia swung into action and moved their fighters towards Khewa on the way to another eastern province Kunar, bordering Pakistan. Taliban said their top commander Mullah Borjan was leading the Kunar operation.

Simultaneous to that, the Taliban forces launched an attack on Laghman and some reports reaching Jalalabad placed them short of Kargha district. Rockets launched from a multi-barrel rocket launcher swooped from Surkhakan where the Taliban are appeared to have formed their third defence-line beyond Darwanta and slammed into Laghman, raising thick smoke and fire.

The students militia took a diversion from the Laghman-Kabul road and pushed their troops further down towards Sarobi where analysts say the students militia are expected to confront some stiff resistance from the government troops.

The Taliban in their forward push also over-ran Hezb-i-Islami's positions at Corps XI at Darwanta, klocking out in the process its radio transmitter which daily aired its propaganda in the name of Payam-iAzadi.

That the pro-Kabul troops were on the defensive was clear from the three bombing raids carried by Kabul jets over Jalalabad. The bomb fortunately fell into the periphery and close to the airport without causing any damage. One eye witness report said three persons sustained injuries. The last bombing raid came at $3.40 \mathrm{pm}$ when a jet made three sor ties before dropping two bombs. Jalalabad's otherwise hush was broken by rattling fire of the Taliban's anti-aircraft guns.

The bombing raids has created fear and panic among the residents. Markets which were open in the morning were forced to shut down again after the first bombing raid. There was little or no traffic and very few people, mainly men on the roads and streets enquiring about the latest situation from the Taliban. The otherwise bustling Jalalabad gave a forlorn look. Taliban's vehicles roaming the streets made the only difference. A vehicle with public address system, assured people of full control of Jalalabad by the Taliban, pledged to enforce a true Shariah under the Islamic Law and asked residents to lodge complaints if any against the former administration with the Taliban topman in Jalalabad, Mullah Mohammad Rabbani on Saturday.

Mullah Rabbani who flew into Jalalabad in the afternoon immediately took to work at the Governor's House meeting his commanders and discussing the situation. The Taliban's assurance however, were less re-assuring. One Haii Mohammad Ali from Besud told this scribe outside the Qasar (Palace) that the Taliban took away his vehide along with another owned by a local Arab.

The fearing of the bombing and resumption of fighting is sending droves of people to the relatively se- cure parts of Nangrahar while hundreds others waited on the Afghan side of Torkham for permission to enter Pakistan. The border remained sealed thqugh.

As Taliban began consolidating their positions in Jalalabad, they are as yet undecided about re-opening of the schools closed two days ago, particularly girls schools which sceptics claimed would probably never reopen. Also on the line are jobs of scores of educated women working for different international relief agencies allowed to work by the relatively liberal Haji Qadeer administration and the now-defunct Nangrahar shura. Expatriates working for such agencies are also feeling insecure, a UNHCR official said most of its staff has evacuated along with some UN officials working for the peace mission in Afghanistan. The only television centre which daily aired documentaries and footage of the activities of some key commanders to a limited audience of Jalalabad ended its transmission a day before the Taliban entered the city. Considering Taliban's aversion to pictures, it is now a forgone conclusion that it would also not resume transmission for ever. A Pushto daily Nangrahar has stopped its printing pending a decision by the Taliban whether or nor it should also carry pictures. The 1400 telephone exchange has also been closed by the Taliban due to security concerns.

All checkposts from the TorkhamJalalabad highway have been removed and disarming of people and collection of weapons has commenced. At-least three persons, two near Nangrahar Hotel lost their lives while refusing to surrender their weapons.

THE NEW'S INTERNATIONAR 


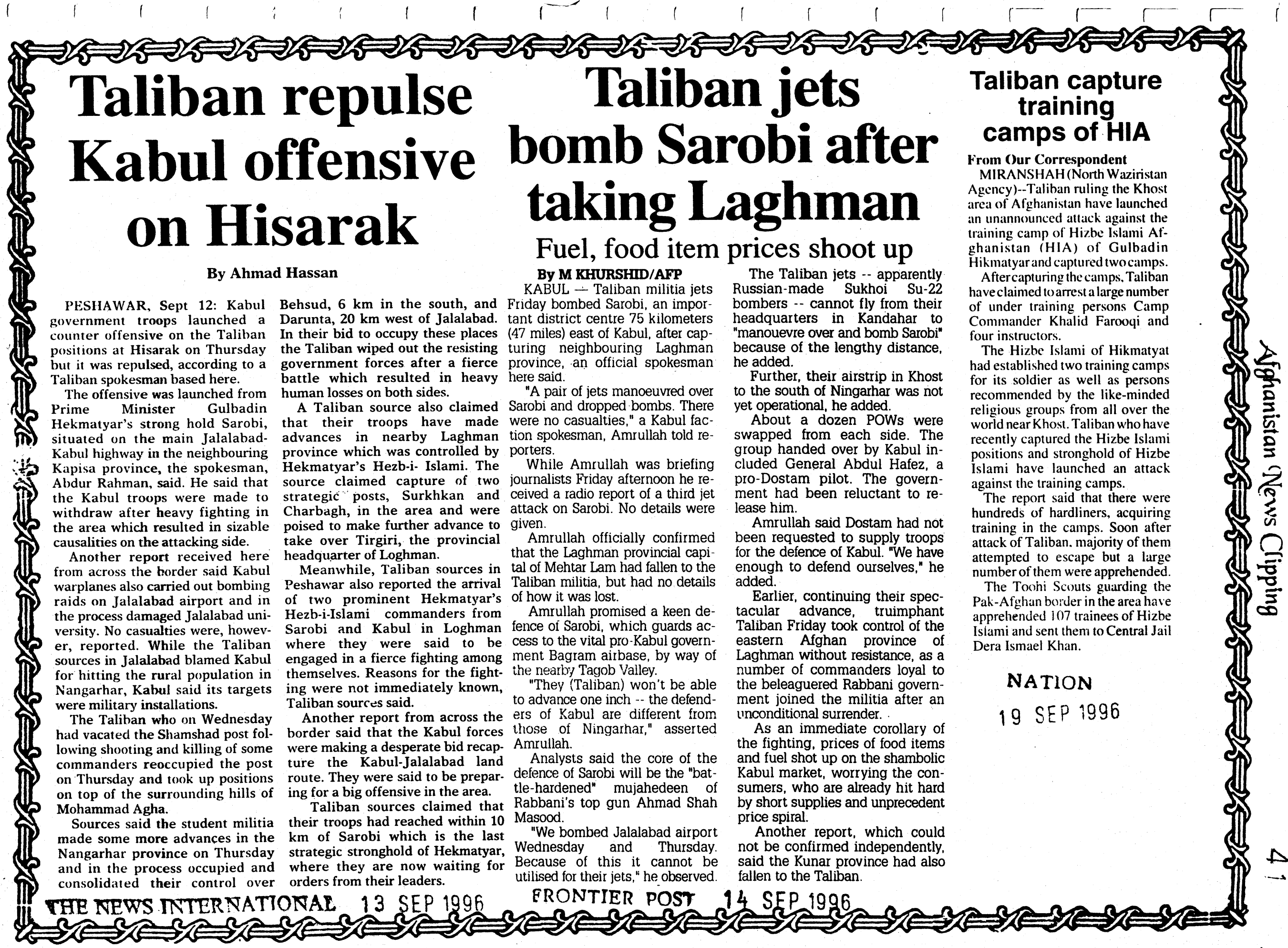




\section{From Ismail Khan}

PESHAWAR: The Taliban Friday captured the Hezb-i-Islami-controlled Laghman province and bombed Sarobi, an important district centre $75 \mathrm{~km}$ east of Kabul. "Laghman has fallen to the Taliban," admitted Dr Ghairat Baheer, Prime Minister Hikmatyar's son-in-law and Afghan ambassador-designate to Pakistan.

Taliban spokesman, Amir Muttaqi told The News from Qandahar that the student militia who were Thursday positioned close to Kargha district of Laghman moved in to capture Mehtherlam, capital of Afghanistan's eastern province at 1 am Friday. "We are in full control of all the districts," Muttaqi said. Laghman, the 18th province to fall to the Taliban, was viewed as an important province near Kabul.

According to AFP's report from Kabul the spokesman of Rabbani go ernment, Amrullah, while talking tc reporters officially confirmed the fall of Laghman, adding "a pair of jets manoeuvred over Sarobi and dropped bombs. There were no casualties." As Amrullah was briefing journalists Friday afternoon he received a radio report of a third jet attack on Sarobi. No details were given.

Laghman's fall to the Taliban has effectively sealed the fate of Kunar, another eastern province bordering Pakistan's Bajawar Agency which analysts said has become a sitting duck. Unconfirmed reports said the ruling Salafi Jamaatud Da'wa of Maulvi Jamilur Rehman was in contact with the Taliban and that Kunar's fall to the students militia was now only a matter of time. Security officials, however, said Kunar has no immediate importance for the Taliban and its surrender to them depends largely on how much re-enforcement they muster.

Laghman's fall to the Taliban, according to sources close to the Hezbi-Islami, was facilitated by the defection of its Commander, Muallim Faulad. The Hezb-i-Islami leader Gulbadin Hikmtyar used Mehterlam as one of his bases following the fall of Charasiyab to the Taliban on October 11, 1995.

Both Taliban and Hezb-i-Islami sources confirmed forces of the two sides were now about $30 \mathrm{~km}$ away from each other on the main Jalalabad-Kabul highway at Sarobi. The Taliban said their forces were positioned at Rikhmen Tangi while the government troops have formed their defence-lines at Pul-i-Istehkam. "The real battle will occur in Sarobi where we will test each other's strength," Baheer said. Taliban said they were bringing in further re-enforcements to capitalise on the series of their recent successes.

Analysts said it was difficult to say whether the Taliban would go for Kapisa province where Tagab and Najrab districts hold strategic importance for them.

The two largely-mountainous districts border Kabul's main military Bagrami airbase and Jablus Siraj and its fall to the Taliban, analysts said, would not only increase pressure on Kabul but also make Bagrami's defenses vulnerable. While Tagab is mainly Pushtoon district, Najrab has mixed ethnic population.
DAWN 24 SEP 1996

Taliban claim capturing
another town

Bureau Report

PESHAWAR, Sept 23: The Taliban are reported to have repulsed an attack launched from Sarobi side by Kabul troops, and captured Abresham Tangi, 30 km from Jalalabad.

The Kabul troops who are des. perately trying to advance on the Kabul-Jalalabad highway, had launched a big attack on Sunday evening, backed by heavy artillery and tanks.

Taliban sources in Peshawar said only four of their soldiers had died and 10 injured in the attack.

Agencies add: Rockets slammed into Kabul on Monday killing six people and wounding 22.

Kabul radio, monitored in Islamabad said the Taliban militia had sent dozens of rockets crashing into residential areas overnight and during the day.

\section{Reports of fighting between Taliban, Laghman people}

From Our Correspondent

PESHAWAR - Although fighting erupted between Taliban and the people affiliated with Hizbe Islami of Engineer Hekmatyar in Ali Shang district of Laghman province on Wednesday but there are contradictory reports in this regards.

The reports pouring in Peshawar from across the border reveal that Taliban after consolidating their positions in Laghman province initiated efforts to disarm the civilians. The civilians, mostly the tribesmen opposed the said steps of Taliban and they entered in fighting with each other.

While another. report reveal that Hizbe Islami of Hekmatyar which is still ruling in four districts of Laghman fall to Taliban on September Hizbe Islami of Hekmatyar was reportedly enjoying help of troops loyal to president Rabbani.

\section{NATION}

\section{SEP 1996}




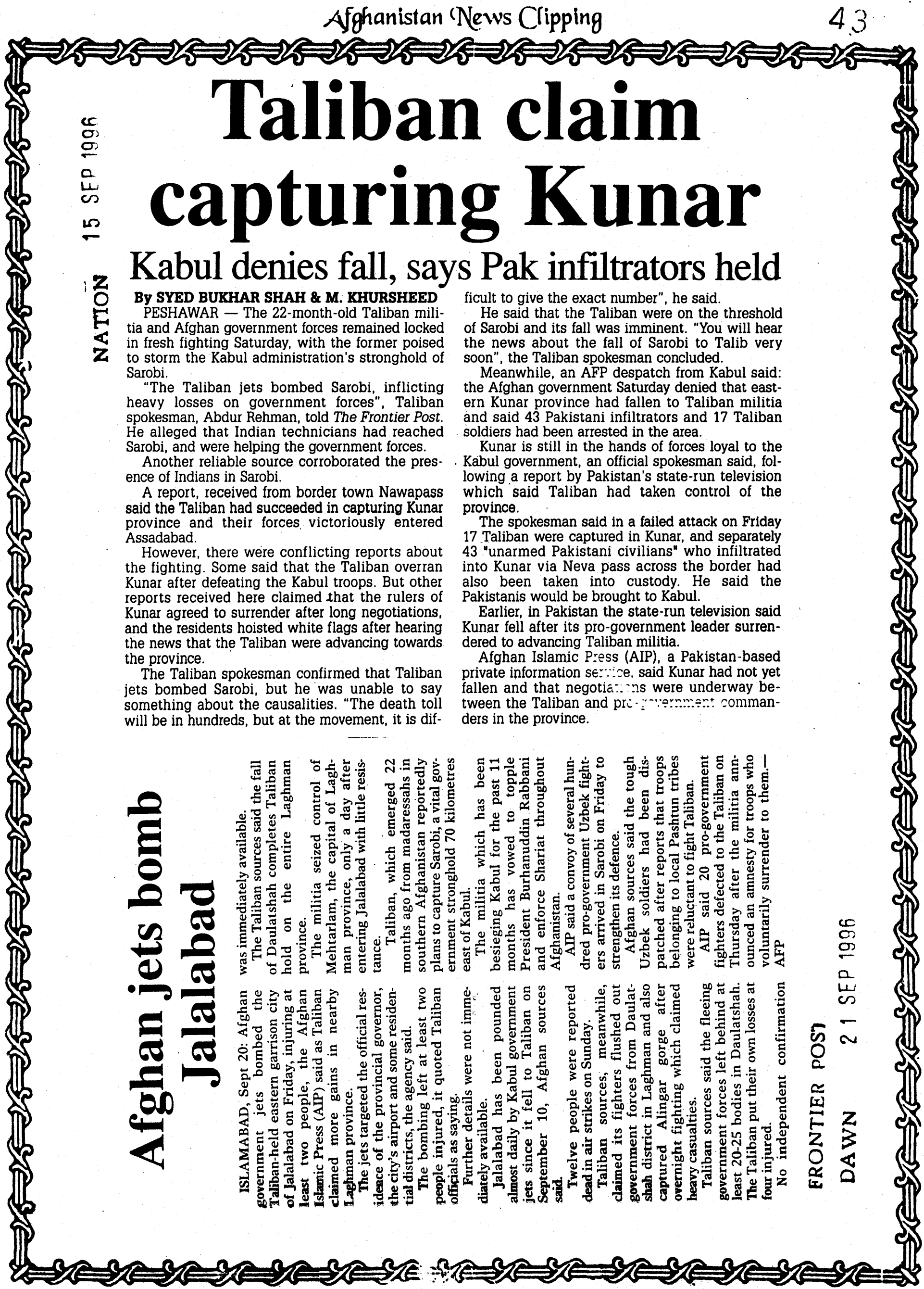




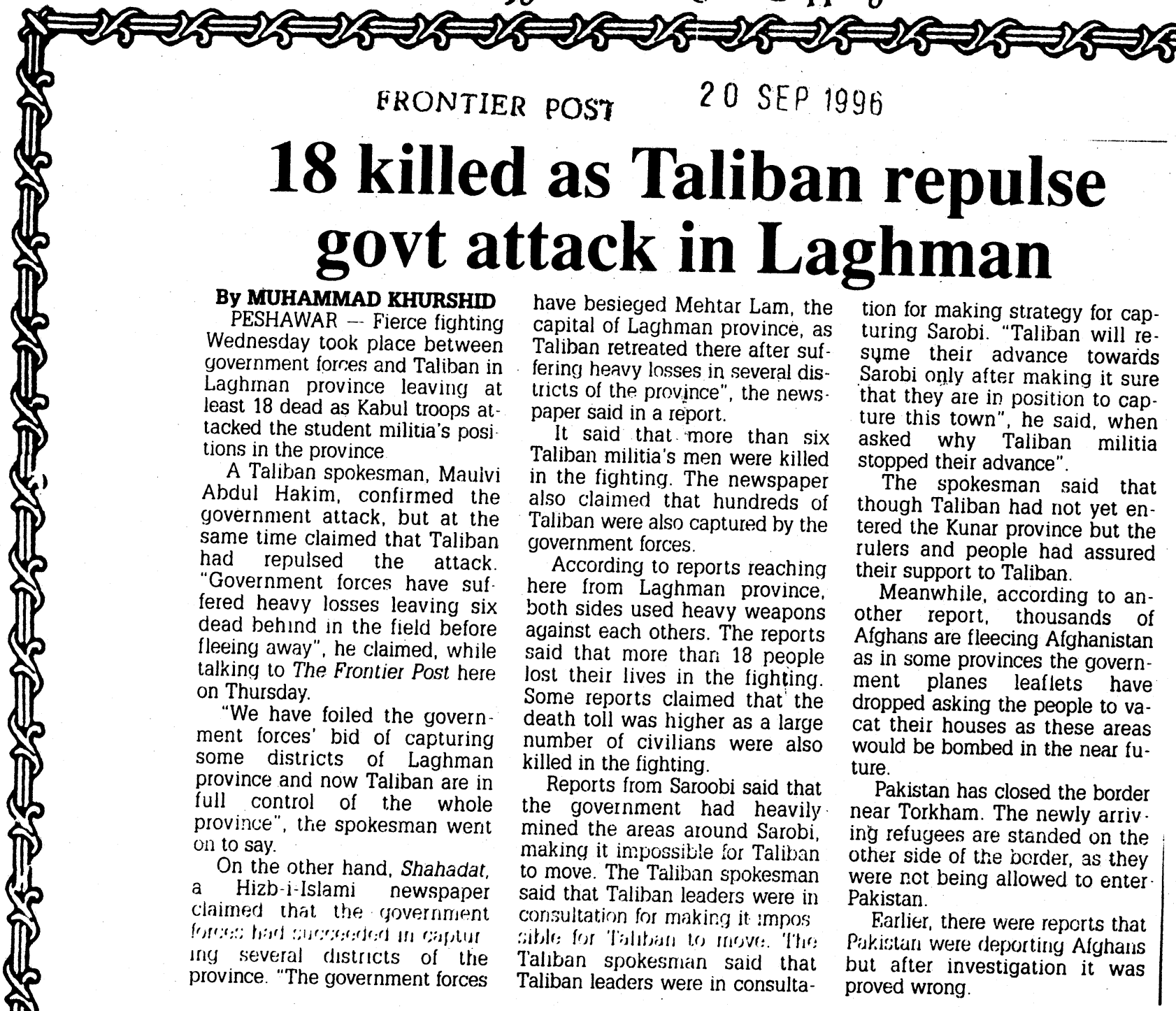

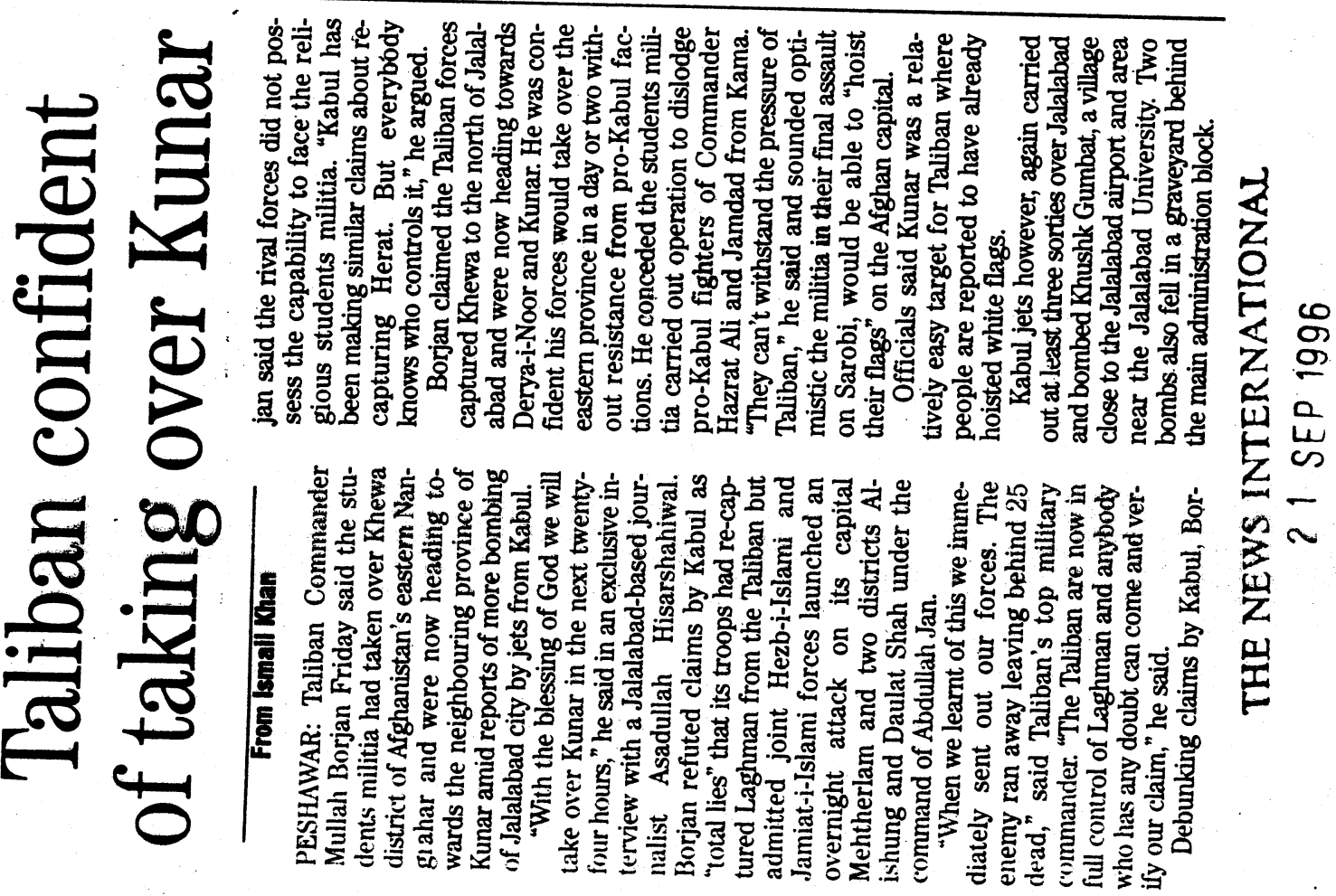




\section{John Zubrzycki}

JALALABAD: Afghanistan's mystery army is on the march again, having taken Jalalabad, the country's second-largest city, last week with hardly a shot being fired.

It took only a hundred soldiers of the Taliban militia to take control of this strategic city.

As the unpopular warlords who had controlled the city fled before the Taliban advance, the people of Jalalabad threw flowers, food, and money at the militia, praying that peace might at last be restored. But the euphoria over their occupation of Jalalabad may be short lived. Many people are wary that the movement's ideals may transform the once moderate country into a hotbed of activism.

"We want to establish the first truly Islamic state and extend the jihad from here," says Saifullah Khan, a young fighter with a distinctive black turban and a Russian-made Kalashnikov assault rifle slung casually across his shoulder.

"We will take back all the countries that were once Muslim - from Spain to India," Khan continues.

The Taliban, who appeared mysteriously on the Afghian political scene two years ago, say they want to turn their war-ravaged country into the world's most ultraorthodox Islamic state, where even music and the playing of games is prohibited. In the two-thirds of Afghanistan already under their control, girls are prevented from attending school, women cannot work, and anyone caught stealing has their arm amputated.

For the people of Jalalabad, however, peace - and not the preaching by Ulema uiding the Taliban - is all that matters for now. "The first need is security, here and all over Afghanistan," says Izzah Tullah, a local aid worker. "Until they (Taliban) came, every family was guarding their houses at night because of the looting by government soldiers. Now people can sleep peacefully."

Life in Jalalabad is returning to normal after government jets bombed the city last Sunday, killing 12 people and injuring scores more. Shops are slowly reopening, but not a single woman can be seen in the markets of what was once eastern Afghanistan's bustling commercial capital. In the former governor's office, Taliban commanders confer about the establishment of a new local council to run Jalalabad. The city's previous governor and his warlords fled before the takeover, leaving behind arms, ammunition, typewriters, and files.

"The people have welcomed us, they were clapping when we came," recalls Muhammad Issaq, a Taliban commander. "The people of Kabul will welcome us too," referring to the citizens of the capital."

The Taliban movement says it is firmly committed to establishing an Islamic state based on the teachings of the holy Quran and a strict interpretation of Shariah. "First, we have to take all of Afghanistan, and then we will decide on the basis of the holy Quran and the Shariah how we will run the country," Issaq says.

The movement's leaders strongly deny allegations that they are receiving any outside assistance, especially from Pakistan. "No one helps the Taliban. Only Allah (God)," Isaaq says.

The group now controls 20 o: Afghanistan's 29 provinces and i; preparing for a final assault agains, the forces of Presiden Burhanuddin Rabbani, who ha complete control of only thre provinces and the area around the capital.

But the Taliban will have to fight hard to dislodge Presiden:t Rabbani. Made up largely of Pathans, the largest ethnic group in Afghanistan, the Taliban has met little resistance in the Pathan-dominated south and east of the country.

Kabul, however, is dominated by the Tajiks, another ethnic group.

The city is also strongly defended by the army of Rabbani's closest ally, Commander Ahmad Shah Massoud and the soldiers of Premier Gulbuddin Hekmatyar.

In recent weeks the Rabbani government also tried to enlist the support of General Dostum. But Kabul's initiative was rejected by Dostum.-Dawn/CSM News Service 


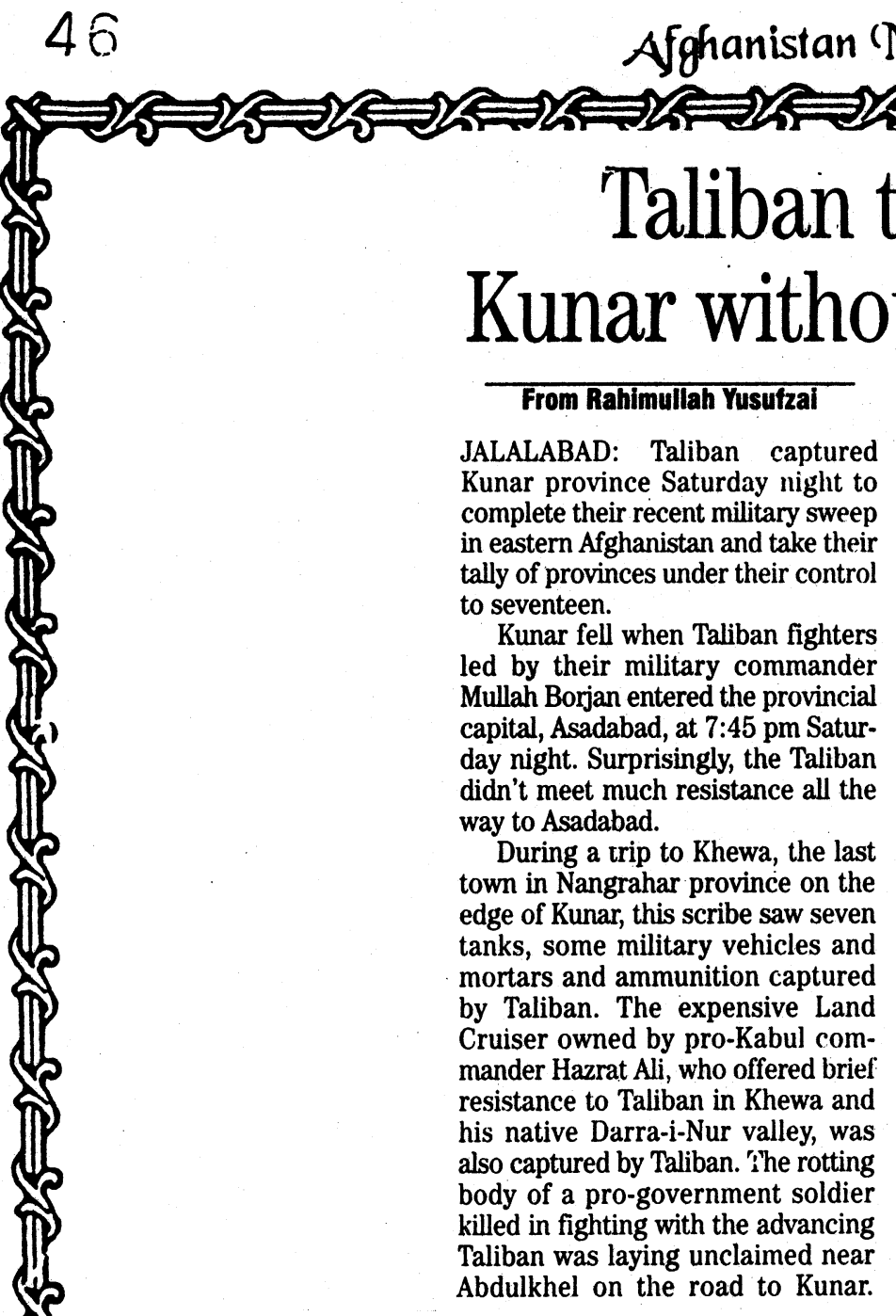

Later in the afternoon, a dilegation of elders arrived from Kuntip to reclaim the body for burial.

Earlier, the Taliban has led-over four bodies of pro-government soldiers killed in fighting at the mouth of Darra-i-Nur to their relations. Khewa and Darra-i-Nur fell Saturday afternoon, enabling the Taliban to break through the government frontline and head for Asadabad. Taliban fighters arriving from Kunar valley told The News that they received a warm welcome instead of any resistance at roadside lowns like Kuz Kunar, Nurgal, Chowki and Asadabad.

They said the Taliban crossed Kabul river Sunday morning to occupy Marawara and Sarkani districts on the border with Pakistan. They added that Taliban were now heading for Pech valley, a stronghold of the Jamaat-ud-Da'awa-wa-Sunnah party which earlier dominated the pro-Kabul administration in Kunar. They claimed that the former Kunar governor had sent a message from

Continued on Page

\section{Taliban take over Kunar without resistance}

\section{Continued from Page}

Pech valley that he was prepared to surrender to Taliban.

In Darra-i-Nur, women took refuge in mosques when Taliban entered the valley and held copies of the Holy Quran in their hands to seek protection. Mullah Abdul Ghani, a Taliban commander said they told the women and their menfolk that Taliban would protect their life and honour even at the cost of their own lives. He said pro-Kabul commander Hazrat Ali had warned the people in Darra-i-Nur that Taliban would rape their women and loot their houses.

This correspondent also saw delegations of people from Khewa, Darra-i-Nur and lower Kunar valley arriving for meeting with Taliban officials to assure them of their all-out cooperation. Most of these delegations complained that their former mujahideen rulers committed every crime against the population and had turned into criminals.

Meanwile, government warplanes bombed Taliban positions on the Jalalabad-Kabul highway and in Laghman province. There were also reports of fighting on the Sarobi frontline where the Taliban from their bases in Spine Thana were confronting government troops entrenched near Wrekhmin Tangi. Taliban officials in Jalalabad also denied government claims that their troops had advanced up to the Surkhakan bridge on the Jalalabad-Kabul road and contended that instead they have broken through the government frontline near Mashali Kotal.

AFP adds: The Afghan Islamic Press (AIP) said at least five people were killed in two days of clashes between the Islamic militia and progovernment elements at Khewa just outside Kunar.

The dead included a pro-government commander, identified as Sher Afazal, the private information service said. Taliban's next major target is expected to be Sarobi, a strategic stronghold of the Kabul coalition government of President Burhanuddin Rabbani and Prime Minister Gulbuddin Hekmatyar. Sarobi is only 70 kilometers (43 miles) east of Kabul.

Taliban sources said a top council of the militia had n,t vet given a final signal for a full-hledged assault on Sarobi, where the government forces have been beefing up their defences.

Meanwhile, the key city of Jalalabad, capital of Nangarhar, has come under air strikes twice by government jets in the past week, which reportedly left 14 people dead. The Taliban official in Kandahar said there were no casualties in the last raid on Friday as the bombs landed in an unpopulated area in the outskirts of Jalalabad.

"The illegitimate government will not be able to intimidate us by carrying out such raids," the official said. The recent surge in fighting has put UN mediation efforts in Afghanistan on hold and renewed Kabul's claims that Pakistan is providing support to the Taliban, sparking fresh tensions between Islamabad and the Afghan government.

Pakistan last week postponed a visit by a senior official to Kabul to pave the way for reopening the Pak: istani embassy which had been burned in September 1995 in a mob attack. Relations between the two neighbors had been improving following the visit of a high-level Afghin delegation here in August. 


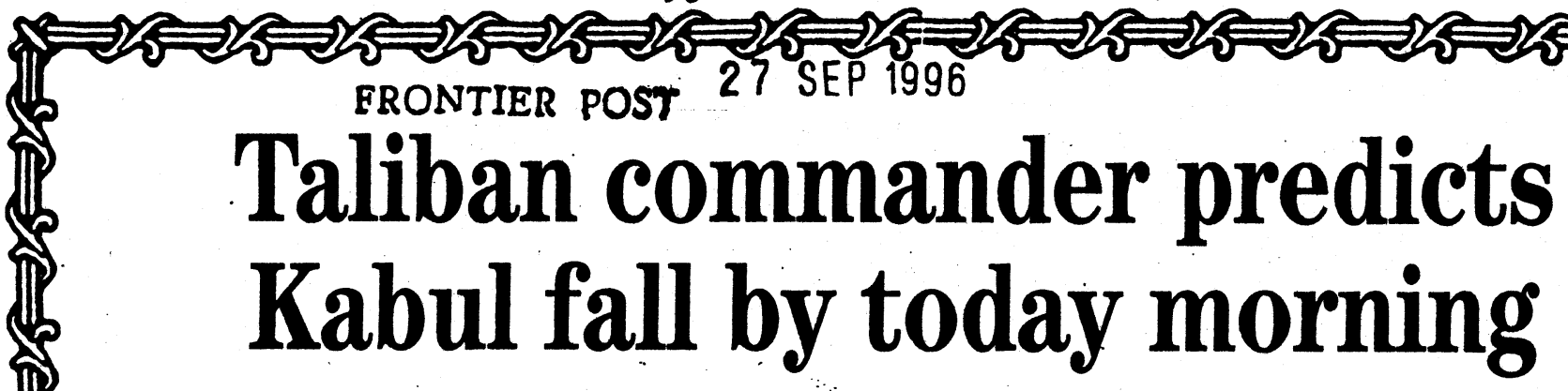

\section{From Rahimullah Yusufzal}

JALALABAD: Maulvi Mohammad Rabbani, the number two man in the Taliban Islamic movement, has predicted the fall of Kabul by Friday morning.

In an interview with The News in Jalalabad Thursday night, he said the Taliban have entered Kabul and half the city was now in their possession. "The Kabul administration is now on the run," he maintained.

Maulvi Rabbani is chief commander of Taliban troops and is also heading the administration in recently captured Nangrahar, Laghman and Kunar provinces in eastern Afghanistan. From his offices in Jalalabad, he is busy round-the-clock guiding both his military and civil officials. He also keeps in constant touch with the movement founder Maulvi Mohammad Umar in Kandahar.

Queried about Taliban's aims once they capture Kabul, Maulvi Rabbani said their objective is to enforce an Islamic system in the whole of Afghanistan. "Kabul is just one major stop in our march towards complete victory," he remarked.

In reply to a question, Maulvi Rabbani clarified that the general amnesty announced by Maulvi Umar was for junior civil and military officials and not for people like Prof. Rabbani, Gulbaddin Hekmatyar, Prof. Sayyaf and Ahmad Shah Masood whose hands were red with the blood of Afghan Muslims. He said all such people would be dealt with according to the principles of Islam. He added that the fate of former president $D r$. Najbullah would be decided by the Afghan nation in accordance with Islamic teachings.

Asked about future Afghan policy towards Rasheed Dostum' Junush-iMilli Islami, Maulvi Rabbani added that they had satisfactory ties in the past and the two sides would hopefully overcome the country's problems through a dialogue. He added that Taliban wanted cooperation of not only Dostum but also all other forces to enforce an Islamic system in Afghanistan.

In a reply to a query about future role of former king Zahir Shah now that he has expressed his intentions to return to Afghanistan, Maulvi Rabbảni said the ex-monarch like every Afghan Muslim was welcomed to come and serve Afghanistan and Islam. "We have no problem with Zahir Shah or others," he said.

Asked about Iranian government statement that the Taliban wouldn't be able to force a military solution of Afghan problem even if they capture Kabul, Maulvi Rabbani argued that Taliban had tried their best to find a negotiated settlement but were constrained to opt for a military solution after having exhausted other options.

Responding to the UN call for an immediate cease-fire, Maulvi Rabbani contended that refusal of the illegal and unrepresentative Rabbani administration to step down had lead to the latest round of lighting and bloodshed. "I invite journalists from all over the world to come and identify one single Pakistani soldier or militiaman in Taliban's ranks, "he remarked when asked to comment on Kabul's oft-repeated allegations that Pakistan was providing military assistance to the Taliban.

\section{Taliban attack on Kunar imminent}

\section{By Ahmad Hassan}

PESHAWAR, Sept 21 : As a battle between Talbian militia and pro- Kabul troops for the control of Kunar province seems to be imminent, the Jamalat-i-Iawat, a pro -

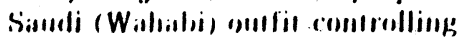

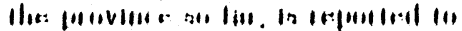
have sent to Kunar some 400 trained students, pulling them out of various local madrissahs, as reinforcements, well informed sources told Dawn on Saturday.

Kabul planes again bombed Jalalabad airport on Saturday afternoon. No details of damage or casualties were, however, available.

The Kabul planes, it may be mentioned, have been targeting Taliban positions almost daily in the Nangarhar province ever since the militia took over control of the provincial capital on Sept 11 last. Two sorties were made on Saturday , a Taliban source confirmed, while talking to Dawn, but refused to dis-

\section{close losses.}

Earlier, the Taliban had aban-. doned its plans to attack Kunar after some prominent commanders from the province met the militia's leaders and assilred them that

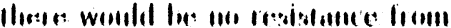
their side. However, the administration of the province was not ready to give up as easily as the Nangarhar Shoora had done and left Jalalabad at the mercy of Taliban. Unable to gain control of Kunar province peacefully , the Taliban have started preparations for an offensive, after taking Khewa, the first district bordering with Jalalabad. Meanwhile, Maulvi Samiullah, head of Salafi party and a member of Hekmatyar's cabinet in Kabul and a patron of Kunar province's ruling shoora, has arrived in Peshawar to supervise efforts being made for defending Kunar against an imminent Taliban onslaught, according to the sources.

\section{DAWN}

22 SEP 1996 


\section{From Rahimullah Yusufzai}

\section{ing with two hangings.}

Enquiries revealed that Dr Najib was shot KABUL: Two years after their emergence in dead at 1.30 am Friday after being forcibly Kandahar, the Taliban achieved their biggest taken away from the UN compound by five military victory todate when they captured armed Taliban and later hanged in the Ariana Kabul late Thursiay night. Square. Ahmadzai was hanged at 6 am Friday.

The Taliban, all bearded and turbaned, Their hanging bodies were dishonoured by forced their way in to downtown Kabul at Taliban, who put currency notes and about $10 \mathrm{pm}$ Thursday night as Rabbani gov- cigarettes in their mouth, hands and pockets. ernment forces kept losing ground in the face The clothes of Dr Najib, who quit as president of a determined onslaught. In fact, the gov- in April 1992 as part of an abortive UN peace ernment troops never recovered from the plan, were splattered with blood and his head shock of their defeat in Sarobi and were consequently unable to put up credible resistance anywhere on the three front-lines east, south and west of Kabul.

After having consolidated their control over Kabul by Friday noon, the Taliban headed for the Bagram airbase north of Kabul. The airbase, which for long served as the lifeline for Rabbani's government, fell without resistance. In fact, its defenders led by Gen Babajan had already escaped. Similar stories of government soldiers abandoning positions and fleeing north out of Kabul abounded. Kabul residents said there were frequent traffic jams in the cities Khairkhana area Thursday evening, as government officials and supporters prepared to flee to Punjsher, Charikar and other places in Parwan, which is the native province of Rabbani government's military strongman Ahmad Shah Masood.

Small processions of people raising proTaliban slogans reached the Gulkhana Palace throughout Friday to announce their backing for the students militia. A tank parked near the palace was garlanded as Taliban drove in and out of the sprawling palace-complex in vehicles flying white flags. The Taliban celebrated their victory by eating grapes and offering to the people.

Beside the palace, another place which attracted huge crowds was the Ariana Square where former president Dr Najibullah and his younger brother Ahmadzai were hanged. The holiday crowed watched with fear and some disgust the hanging bodies of the two brothers who had spent the last four and half year in custody at the UN offices compound in Kabul.

Most people, interviewed by this correspondent, criticised the Taliban for eliminating $\mathrm{Dr}$ Najib and his handsome young brother without a proper trial. It appeared the goodwill for Taliban in Kabul was fast disappear- had a gaping hole from gunshots.

According to the Taliban-controlled Radio Kabul, Dr Najib's secretary Ishaq Torkhi and his loyal bodyguard Jasfar, who were also in custody with him were publicly hanged later Friday. The radio announced the two bodies would remain hanging for three days to send a warning to other criminals.

Maulvi Molaminad Rabbani, the number two man in the Taliban Islamic movement, in a press conference Friday justified Dr Najib's and Ahmadzai's executions by arguing killed scores of their own people. head of the six-member interim government announced by the Taliban spiritual leader Mullah Moh: mmad Umar, said others who violat. Islam and betray their nation would meet the same fate. He said past rulers like, Gulbadin Hekmatyar, Sayyaf and Masood too would dealt with in accordance with Islamic principles.

The six-member council, a communique from Kandahar said, included Mullah Mohammad Ghaus, Maulvi Ghayasuddin, Maulvi Shamsuddin, Maulvi Abdul Razzaq, Maulvi Mohammad Hasan and Maulvi Fazil.

The communique called on the international community to extend diplomatic recognition to the new government which controls Kabul and major part of Afghanistan. It also announced suspension of services of all diplomatic staff in Afghanistan's foreign missions and asked host countries to take care of Afghanistan's state property. The communique urged the UN and interthat they were communists and had Maulvi Rabbani, who was named the

national relief agencies to resume their relief operation and reconstruction work now that peace has been restored to Kabul.

However, in a major policy statement, Maulvi Rabbani said Taliban wanted friendly ties with Gen Rashid Dostum as he had proved himself a practising Muslim despite having a communist past. He said the Taliban and Dostum had good and honest relations in the past and could cooperate in future as well to enforce an Islamic system in Afghanistan.

The Taliban leader declared that in future all aspects of life in Afghanistan would be governed by strict Islamic laws. He said issues like working women and girls education would be decided on the basis of Islamic teachings. "We are not against girls education but we want the women to be taught in accordance with the tenets of Islam," he explained.

The 38-year old Maulvi Rabbani, who on his arrival in the palace sat cross-legged on the ground with common Taliban, insisted that their military commander Maulvi Borjan was still alive. But his tone and that of other senior Taliban leaders clearly showed that they were trying to hide the news of his death in fighting near Kabul. Borjan has not appeared in public over the past week and the military command has gone to his deputy Maulvi Abdul Razzaq.

Meanwhile, prices recorded a fall and the value of the Afghan currency, Afghani registered a dramatic rise with the re-opening of the roads linking with Jalalabad, Logar and Maidan Shehr. Truck-loads of grapes, melons, pomegranates and onions were seen heading for Jalalabad and onwards to Peshawar as the road re-opened Friday after a two-week closure. Meanwhile, ex-president Burhanuddin Rabbani has issued a statement, ostensibly from somewhere in Afghanistan, declaring that Afghans will never accept a government installed by Pakistan. He termed the Taliban regime as alien and said it would meet the same fate as of former rulers Shah Shuja and Babrak Karmal. However, nobody knows the whereabouts of Rabbani, Hekmatyar and Masud. 


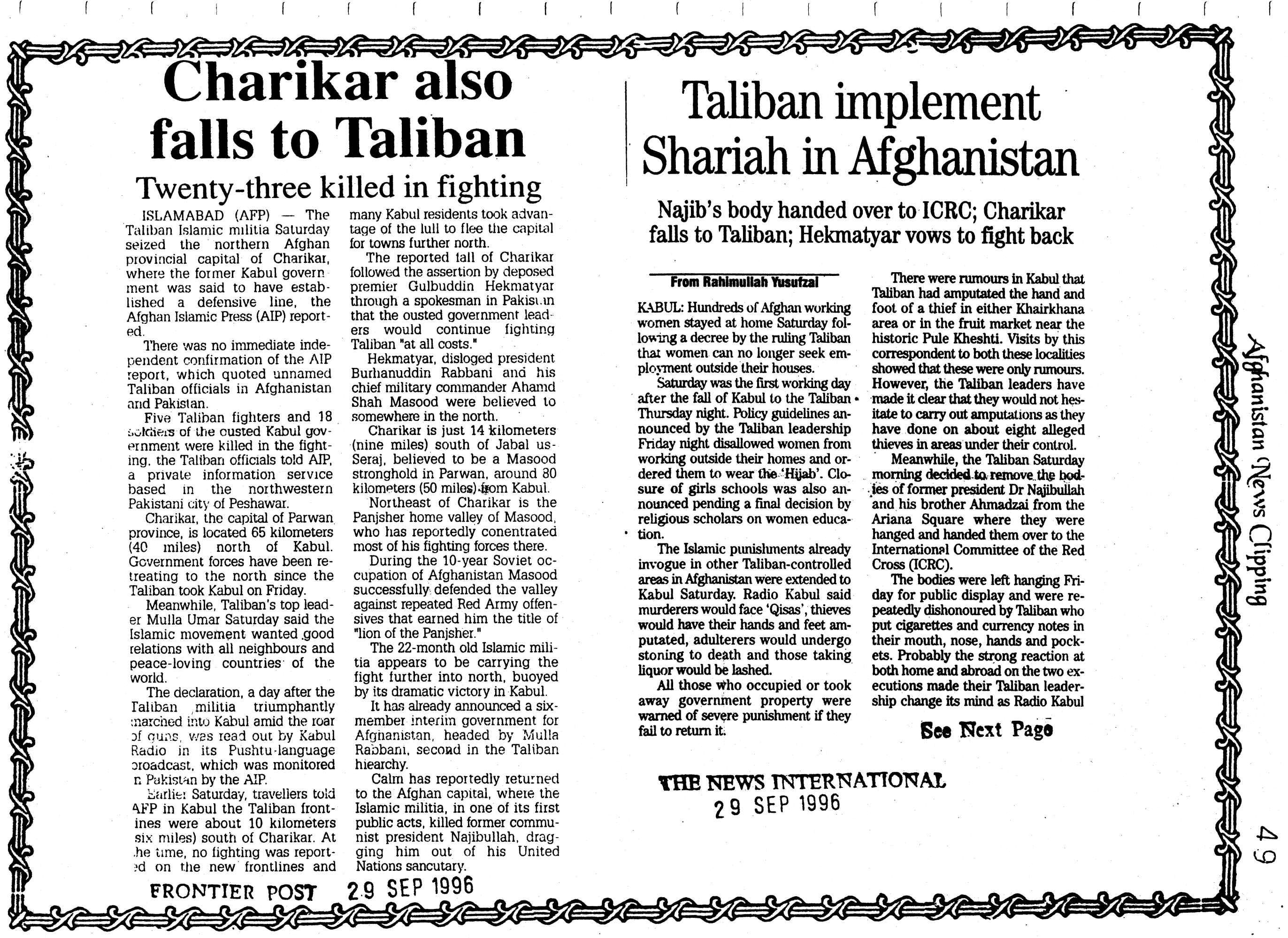




\section{Continued from Page 1}

had earlier announced that the bodies of the two brothers would remain hanging for three days.

A large number of people kept visiting Ariana Square Saturday to have a look at the traffic tower where the bodies dangled from ropes the day before. Most commented that it was a cruel and untimely act by the Taliban. A Taliban spokesman Maulvi Amir Khan Mutaqi told The News that Dr Najibullah's relations would collect the bodies for burial from the ICRC in Kabul.

On the other hand, the six Taliban leaders named on the interim ruling council for Afghanistan by the Taliban Islamic movement's founder Maulvi Mohammad Umar have reached here from Kandahar to hold their first meeting Saturday. The meeting was presided by the council's head Maulvi Mohammad Rabbani and attended by its members Maulvi Mohammad Hasan, Maulvi Mohammad Ghaus, Maulvi Syed Ghayasuddin Agha, Maulvi Abdur Razzaq and Maulvi Fazal Mohammad. The last-named has also been appointed as head of security in Kabul.

The council took a number of decisions to improve the security situation in Kabul and protect the life and honour of the people. It decided to restore power supply to Kabul and streamline civic services as soon as possible. It was also decided to reopen Kabul and Bagram airports to civilian traffic at the earliest.

According to a Taliban military spokesman, their forces have completely occupied Bagram airbase and its surroundings and were now heading further north to crush the remnants of ex-President Burhanuddin Rabbani's government. He claimed the defeated forces were on the run and the Taliban would soon occupy Charikar and Jablus Siraj in Parwan, which is native province of Rabbani government's most powerful military commander Ahmad Shah Masood.

Meanwhile, ousted prime minister Gulbadin Hikmatyar told BBC Pushto Service Saturday night that all institutions of the former government were intact and would continue to function both in and outside the country. He contended the Taliban government in Kabul was illegal and lacked the support of the people. He said the Taliban rule was alien and would meet the same fate as former puppet Afghan rulers Shah Shuja and Babrak Karmal. He said the Taliban were unacceptable to the Afghan people as they were the creation of outsiders. He was also critical of the summary execution of Dr Najibullah and his brother and said the ex-communist president should have been given a proper trial as required by Islamic justice.

Ismail Khan adds from Peshawar: The ICRC said a convoy of thirty-five trucks laden with food stuff and medicines was ready for dispatch to Kabul but said it was awaiting a green signal from its offices in the Afghan capital. "It is purely a technical problem concerning security", head of ICRC mission in Islamabad, Oliver Durr, told The News on phone from the federal capital.

He informed his office was also awaiting clearance from its Kabul office whether or nor resume its flight operation to the Afghan capital. Quoting the Taliban, he said, the students militia were making efforts to reopen Khwaja Rawash and Bagram airports for civilian traffic. He informed the ICRC had enough medical supplies in Kabul but may send additional supplies if required.

AFP Adds: The Taliban Saturday seized the northern Afghan provincial capital of Charikar, where the former Kabul government was said to have established a defensive line, the Afghan Islamic Press (AIP) reported.

There was no immediate independent confirmation of the AIP report, which quoted unnamed Taliban officials in Afghanistan and Pakistan.

Five Taliban fighters and 18 soldiers of the ousted Kabul government were killed in the fighting, the Taliban officials told AIP, a private information service based in the northwestern Pakistani city of Peshawar.

Charikar, the capital of Parwan province, is located 65 kilometers north of Kabul.

Government forces have been retreating to the north since the Taliban took Kabul on Friday.

Meanwhile, Taliban's top leader Mulla Umar Saturday said the Islamic movement wanted good relations with all neighbours and peaceloving countries of the world.

The declaration, a day after the Taliban militia triumphantly marched into Kabul amid the roar of guns, was read out by Kabul Radio in its Pushtu-language broadcast, which was monitored in Pakistan by the AIP.

The reported fall of Charikar followed the assertion by deposed premier Gulbuddin Hekmatyar through a spokesman in Pakistan that the ousted government leaders would continue fighting Taliban "at all costs."

Charikar is just 14 kilometers south of Jabal-us-Seraj, believed to be a Masood stronghold in Parwan, around 80 kilometers from Kabul.

Northeast of Charikar is the Panjsher home valley of Masood, who has reportedly concentrated most of his fighting forces there.

Ghairat Baheer, the son-in-law of Hekmatyar, said the Hezb-i-Islami leader was "safe and fine", adding he would determine his future course in a "collective" strategy with Rabbani and Masood.

Baheer, who was designated as Kabul's new ambassador to Pakistan before the fall of Kabul, said Hekmatyar had spoken to him by satellite telephone.

In Geneva, the International Committee of the Red Cross (ICRC) said it had been able Saturday to distribute its first relief supplies in Kabul since the Taliban's victory there.

At the United Nations, members of the Security Council were to meet Saturday at Russia's urging to discuss the Afghan situation.

Newspapers in Iran were deeply critical of the Taliban. The capture of Kabul was "designed by Washington, financed by Riyadh and logistically supported by Islamabad, ${ }^{n}$. said Jamhuri Islami, a daily close to Islamic hardliners.

WHE NEWS TNTERNATTONAL 
Congressman

Dana

Rohrabracher's recent visit to

Afghanistan and Pakistan comes in the wake of a dramatic escape of Russian aircraft and its crew from Taliban control. That event was preceded by Senator llank Brown's visit to the region which paved the way for the "great escape". But most sig nificant is a perceptible shif in the Afghan policy towards the Zahir Shah option Of all previous, developments, Congressman Rohrabracher's comments are most promising to date.

He believes he can pave the way for total peace in
Afghanistan in 90 days. The Afghan leadership that he has talked to about Zahir Shah's re tum have welcomed the idea with an open heart and mind. This certainly signifies a sea-change in evenis concerning Afghanistan. Those acquainted with Afghan af fairs look Dana Rohrabracher sweeping assertions with a pincy sweeping assertions with a pinch
of salt. But the US holds the key: being the sole (niega) superpouver being the snle (mega) superpower compred to lesser powers! But compared to lesser powers! Bu
words need to be hacked by actinns. After the Soviel withdrawal. the Afghans complain, the US had literally washed its hands of the Afghan affairs. This has demoralised the Afghan intelliEentsia as their hopes for freedom have heen dashed by events in the wake of mujahideen victory in Afghanistan.

Until recently, most Afghan factions. having a say in the fu factions. having a say in the fu
fure staius of $A$ fehanistan, had demonstrated serious reservatemonstif if net ahsolute opposition to tions. if not ahsolute opposition to Zahir Shah's re-cniry into Arghinistant. Alos importan thas disparale factions. The political vacuum created during Jehad have far-reaching and bleak consequences for Afghanistan's future. IIs political and social institutions are in a mess. Will the West. particularly the USA shoulder the responsibility for the surry state of affairs in tions of leadership and comprehensive political framework the mos important concerns the most important concern haunting Arghanistan s future sta-
tus and thus need utmost attention.

II was a very demainding. balancing act. pitching one faction ancing act. pitching one faction
against the other. The strategy of supporting proxies agains favourites of other competing nations of the region has often bee a frustrating and unpredictable af fair. The efficacy and usefulness of each player depended upon the financial and political support of the sponsor nation. This arrangement, more often backfired than delivered in the long run. This has been the preslicament of Pakistan's Afghan policy. which again has heen hostage to various competing Pakistani agencies and interest groups following several, interest groups fnllowing several, often divergent. policies on is a testimony to Pakistan's failis a testimony to Pakistan's fail-
ure to frame a coherent Afghan policy.

\section{Shah: the one
only option}

Adil Zareef

But then Afghanistan always its equally novel location. Straddling along the mighty Hindukush mountains, this mysterious amalgam of various tribes and nationalities had to play an unprediclable game - a kind of political huzkushi io kecp itsel afloat in ari arena where major powers of the world - the tsarist Russia and the imperial Britain masterminded their ancient verIot of imagination, insight and in trigue.

Amir Abdur Rehman Khan, the architect of modern to 1901 in who ruled rom 188 vulnerable perited "His country's sinall power like Afghanistan, which is ler like Afghanistan. which is like a goat between two two strong millstones of the grinding mill, stand in the way of grinding milt, stand in the way of
the two stones without being ground to dust?" But Abdur Rehman Khan had the answer. In order to keep Afghanistan from

insurgents, as he had little say in he was finally deposed by his the matter. Ile understood the forceful first cousin. Sardar Daud. lim:tations of his country's eco- On April 27, 1978, adio nomic backwardness as it was re- broadcast announced: "for the sponsible for its lack of in dent foreign policy. The two were Afghanistan an end has been put a wary to each other.

war a way, the country's back- Mohammedzais. All powers walruness was vital to continued passed to the hands of the mass Aghan self-determination. As es". On April 28, 1978, Daud long as it remained inaccessible Khan, along with his family, was and poor, it would be unattractive killed in the presidential palace to those with imperial designs. and Afghanistan wis declared as The fastest way to build a modern Democratic: Republic military deterrent against foreign encroachinent would be to develop the nation's economy with the aid of foreign investment, but to lake that course would be to invite the enslavement it was dewas scrupulously adhered policy Sardar Daud Khan's embrace of the Soviet Union and the subsequent coup d'etat that eventually paved way for the most traumatic civil war in Afghanistan's history. During the 1950 s, the decrease in foreign aid had led to unemployment among the restless new
intelligentsia whose number wen

\section{Afghanistan always posed a unique situa-} tion owing to its equally novel location. Straddling along the mighty Hindukush mountains, this mysterious amalgam of various tribes and nationalities had to play an unpredictable game - a kind of political buzkushi to keep itself afloat in an arena where major powers of the world - the tsarist Russia and the imperial Britain masterminded their ancient version of realpolitik. It involved a lot of imagination, insight and intrigue.

becoming a goat, a grain of wheat or anything remotely digestible by the hungriest of imperial lions or relentless millstones, his policies were geared to secure internal. loughness, impermeability and integrity that would deter any
foreign power from undertaking foreign power from undertak

At the same time he main tained a capability for smonth manocuvring between potential invaders, balancing one against the other. With these attributes, the Afghan trithes must have seemed to the two imperial millstones more like ball bearing than grains of wheat. His policies. like those of his predecessors in Kahul's royal palace, were religiously followed by his succes-

Russia and Britain came to un derstand the advantage of all concerned parties concerned in this situation. Each feared other's in tention, and cach perceived the useful rule of an inclependen Afghanistan that could play in kceping the (wo) empires from coning into inadvertent conflict along a common horder. Thus Afghanistan became a model Rehman. who had to deal with some twenty major tribal insurrections during his, iwenty-one year reign, had no desire to take on responsibility for this whole up with the expansion of the educational programme. Afghanistan's fragile democracy ble of handling the complex problems of a rapidly developing economy. Reliance on "democratic" political instruments (the ic" political instruments (the
PDPA and Parcham), however. hDad proven as ineffectual an aphad proven as ineffectual an ap-
proach for the USSR as reliance proach for the USSR as reliance on purely economic penetration had shown itself during the previous decade. It was time for a new effective Soviet influence on the country's politics from behind the cenes.

The end of democracy in Afghanistan came about on July 17. 1973, when Sardar over the country, this time in nearly blondless coup that saw the king banished into exile, the constitution abrogated and civil liberties suspended. Afghanistan had returned to one-man rule. King Zahir Shah's thirty years of trouble-free, tranquil and peace. ful in Afghanistan's history. The young Zahir Shah "reigned but did not rule" only coming into his own as a monarch in 1963. In the interim, according to Afghan Irain his his uncles ran the country Zahir Shah remained on throne in all for fourned on the rule is remembered as the most

Afghanistan with 'Noor Mohamnied Taraki as head of the new government. The reign of the Mohamedzai family extending almost unbroken back to the early ineteenth century had ended; the ong-term Soviet goal of estabishing a pliable regime in Kabu Finally. Anir Abdur Rehman pessimistic prophesy became reality. Moreover, it was the Iwentieth century equivalents of foreign-built railroads, airports and highways that paved the way for the 1979 Soviet invasion. Afghanistan, that had cherished its non-aligned status for over two centuries, was to become empower in the most brutal superpower confrontation in modern frastructure, killing over a million people. But the most tragic consepeople. But the most tragic conse-
quence of this war was the disrupquence of this war was the disrup$A$ unique blend of tribal and contemporary order sustained it into modern age until the Soviet inva sion. The debilitating conse. quences of this disruption can he felt after the Soviet withdrawa and the mujahideen takeover. who have failed to ensute pence and stability of the pre-war years.

The "progress" the communists promised has ended up Iurning Afghanistan from a medieva paradise into a faceless illusion. Afghanistan to become a model of Islamic revivalism, have in their lust for power and absolute truth transeressed the worst standards of harbarism and intolerance. Both have come 10 realise that perfect doctrines do not translate into perfect systeris of be within its values and social pit rameters. Both communist and radical Islamic systems tried and failed owing to the inherent in spirit of Alghans negate the free arian social order.

Since the present warring lead- 
LAHORE-Despite the hectic efforts of the religious leaders from Pakistan and especially those of Jama' at-i-Islami to bring an end to the civil strike and restore peace in the neighbouring Afghanistan, the chances of normalisation in that country in the near future appear to be bleak.

In the present scenario the three major controlling factions in Afghanistan are the central forces in Kabul headed by Professor Burhanuddin Rabbani, the 'rebellious' Taliban and General Abdul Rasheed Dostum. All the three factions are controlling the country in parts, Taliban being in control of 15 out of total 30 provinces, 9 under the control of central coalition government of Kabul and rest by Dostum and other scattered groups of Mujahideen. Taliban headed by Mula Muhammad Umer, regarded as 'Amirul Momineen' under the Islamic concept of state, are in control of half of the territory of the country, but From An this territory has lower-

density of population as compared to the areas controlled by Kabul government. As such on the question of referendum or elections or building up of a countrywide 'Shura', Kabul definitely has an edge over the other factions. Those factions are well aware of the fact and are declining the offers of dialogues and proposals of inception of new government through such means.

The present ruling Kabul coalition government, with Burhanuddin RabReport bani as President and jum Mufti Prime Minister, has fiium Mufti nally taken shape after the compromise between the two leaders through the mediatory efforts of JI Pakistan Amir Qazi Hussein Ahmad, earlier this year. Prior to that both of them were at draggers drawn for a period extending over more than four years. Killing men of their respective factions. Both publicly claim that the agreement between them is going on smoothly but a palpable tension does exist. This tension should have been dissipated in the face of Taliban threat. General Abdul Rasheed Dostum a former ally of Hikmatyar is ruling yet another part of the country unchallenged by anyone. He enjoys the command of a well-equipped and finely trained army in the country and according to some experts he is the man who could come out victorious in view of the prevailing situation. It is also speculated that in the battle between Kabul and Talihan he is sup- porting the latter.

Recently a privately organised fiftymember delegation of Ulema and Mashaikh from Pakistan visited Kabul and met the top leaders of the coalition Kabul government including President, Prime Minister, former Chief of the Security Council of Afghanistan Ahmad Shah Masood and presently an important member of Shura Hum Ahangi. Besides then Abdul Rab Abdul Rassul Sayyaf, is also member of Shura Hum Ahangi along with former Prime Minister of Afghan government in exile and Governor of Nangarhar province Qadeer Khan. The Ulema from various schools of thought had claimed impartiality but claimed that since Taliban are religious students and they being their teachers have clout over them and could play a role to bring Taliban to the dialogue table. Ironically their area of activity in Afghanistan is to make attempts to effect a ceasefire between the Kabul regime and Taliban only. Their meetings at Peshawar prior to departure to Kabul revolved around the agenda of compromise between the two groups acknowledging Dostum as third group but discarding him as a 'Coummunist, Anti-Islamic and a shrewd person who was taking benefits from the struggle of the other two groups'. The Ulema in their meetings took view that Dostum was stock-piling arms while the other groups were exhausting themselves fighting each other and Dostum was the potential danger to a true Islamic Government in Afghanistan. As it had been proved during the Russian control of the country that there was no danger to Islam. Rather it was the might of the Faith that defeated the Russians. The real danger in fact was the division of the country. One thing is clear that whether Afghanistan remains united or divided, Islam will rule supreme. The point to ponder is that division of the country would weaken the Islamic Ummah as a whole and the proposed Islamic block in the region. As such the purpose of the peace efforts should have been to restore peace in the United Afghanistan by every. party irrespective of its affiliations, tilt, philosophy, beliefs and priorities.

The vested interest and the international diplomacy of the unilateral world is playing its part in the region. And stability in the region would not be in the best interest of the super power, though it has been claimed that America after the departure of Soviet Union and its disintegration has lost interest in Afghanistan but by and large the Afghans and people of the neighbouring countries understand that US is still playing a vital role in civil war of Afghanistan.

The Kabul regime owing to unabated bloodshed and power struggle is economically crippled and militarily weakened. Afghans crane for peace rehabilitation. After coming to power Rabbani regime needs peace more than anybody else. On the other hand their weak will to fight Taliban is proving counter productive as the other party may take the dialogue offer as sign of weakness. The Talibans do not appear to be ready to held dialogue and are issuing pre-conditions which are impossible to fulfill. The delegation of Ulema from Pakistan would soon be in contact with the Taliban leaders to know their point of view or the charter of demands.

Taliban on the other hand having succeeded in winning the major part of the country have a high morale and consider that they could capture Kabul through the use of force. Neither are they in a mood to share power with anybody. They are not willing to lose at the dialogue table what they won on the battle field. They also realise that odds are in their favour and international forces are behind them. Their success in restoring peace and retrieving arms from the masses in have given them added confidence and feeling that they are better organised and in a position to run the government. However, very recently a group in Taliban has cropped up which realises that anti-Islam forces were using them for their own ends and their dream of a true Islamic government would not come true. However, their demand to bring Zahir Shah to Afghanistan to implement Islam in its true perspective sounds un-natural and motivated by some extermal causes.

The overall situation in the country has become so coplex that even to the safest of the analysis a peace prospect in the country in the near future appears to be remote. The 15-year-old Afghan has seen only war, killings, death and nothing else. No education, no love, no affection only a tale to total deprivation is the history of the country. For rest oration of peace in the country a mutual accommodation, give-and-take, submission and nationalism, Islamic brotherhood is required.

\section{NATION}

11 SEP 1996 


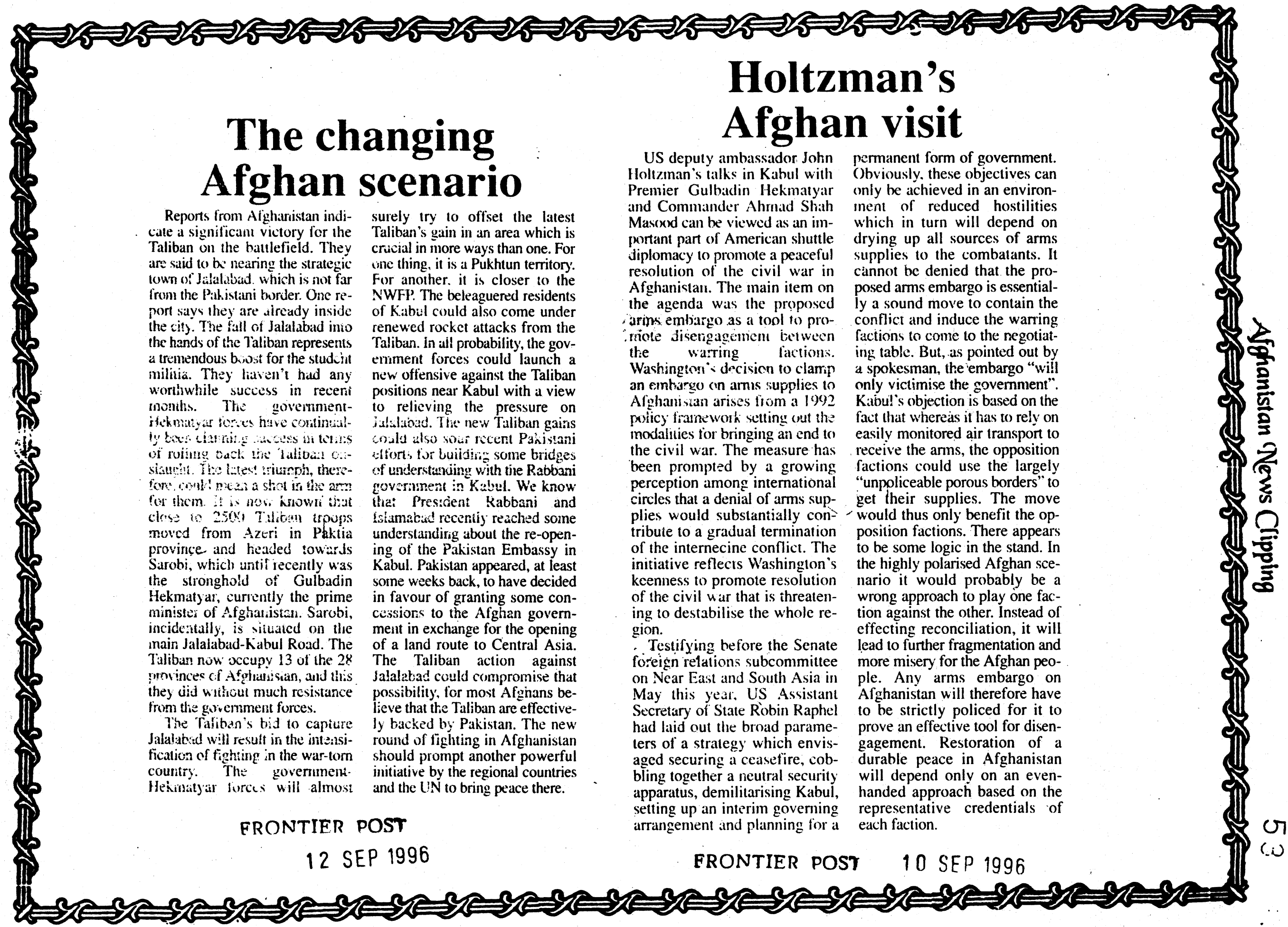




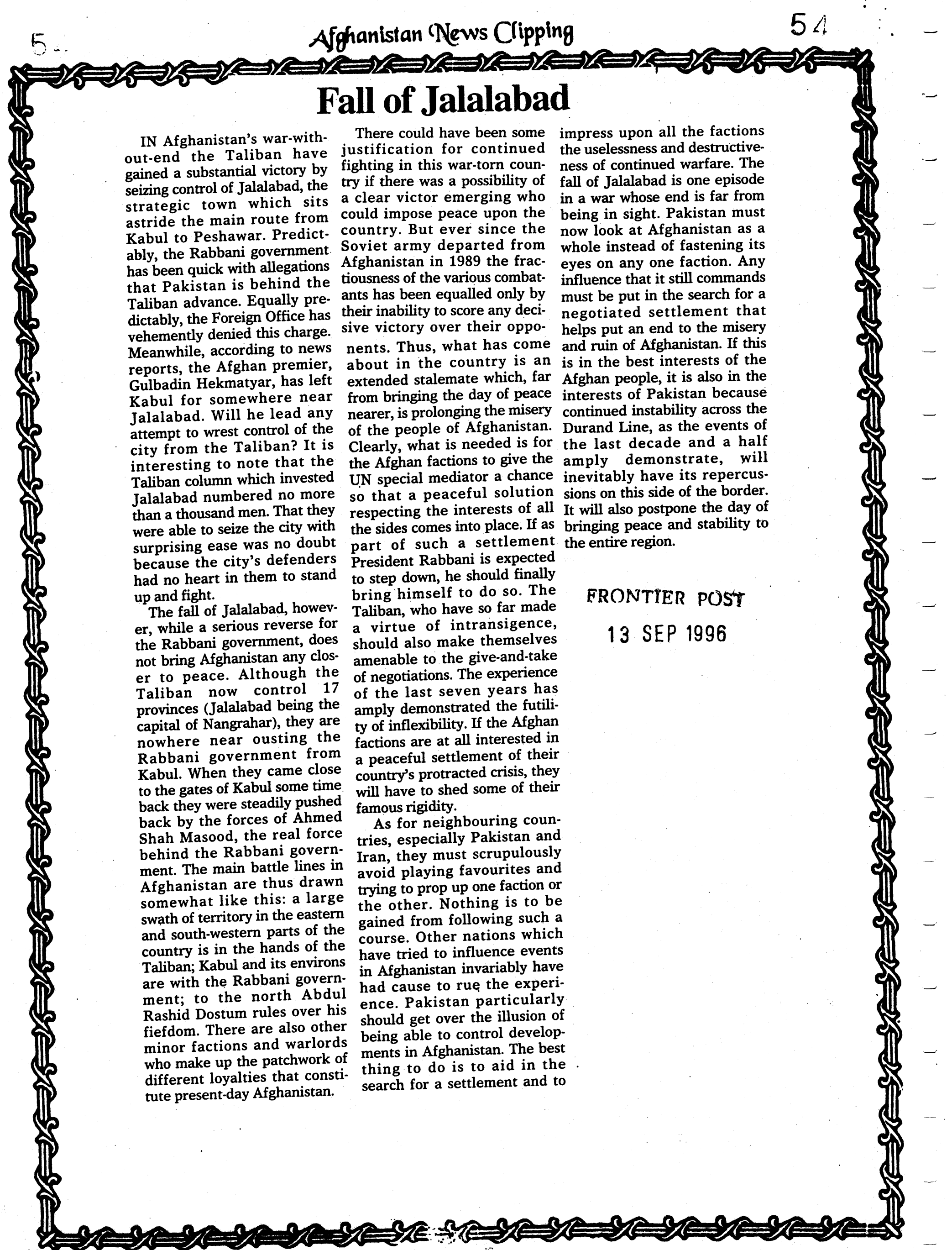




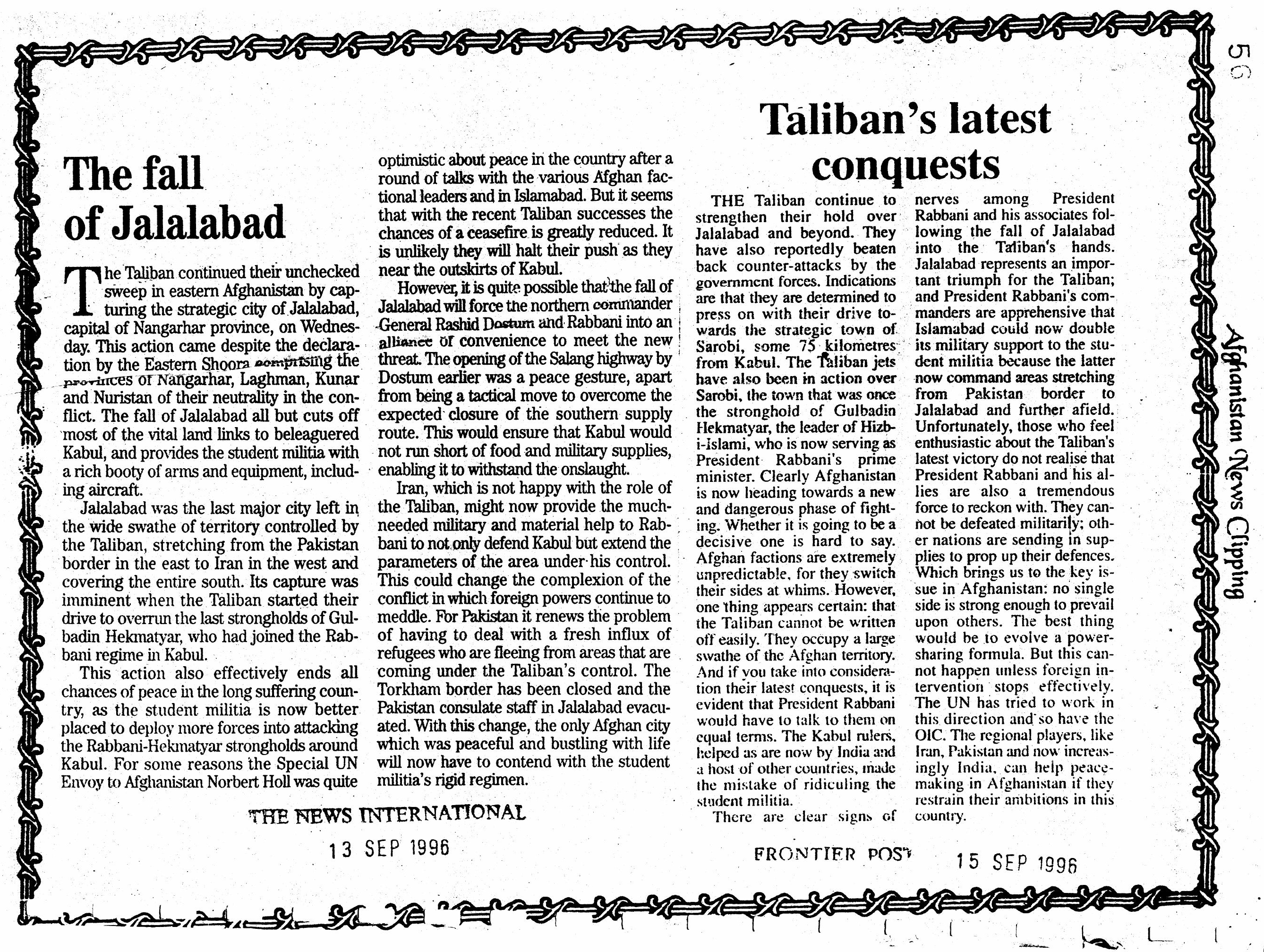


Taliban militia swung into action for the third time since its thception in 1994 by captur ing two more provinces Nangrahar and Leghman. With the new gains in South Eastern Afghanistan, Taliban now control 17 of the 30 provinees, which comprise 60 per cent of the total landscape.

As in 1995 after their mete. oric rise on the Afghan scene, Taliban stumbled at the brims of embattled Kabul they have been encircl ing for the last 11 months Taliban are now hold up at Sarobi in southwest of Kabul.

In the current streak Taliban overrun Jalalabad, provincial capital of Nalygrahar provínce bordering

Pakistan and NeWS am linking it with News analysis Kabul, after its ruling shoora By FAIZULLAH JAN

have sant a two man delegation to Tashkent to rope in Uzbek warlord Abdur Rashid Dostam against Taliban knocking at the gates of Kabul

But Dostam cortainly will not side with a power which is standing on its last log against a force which is spreading its tentacles assertively: Dostam rules an area . northern Afghanistan - which has wit. nesserd almost no war till date after the stepning down of Dr Najitullah in 1992

The factors which greatly contributed to Taliban's gains in elsewhere, are least found in the four provinces _ Jawzjan, Balkh, Sainangan and Paryab Dostam rules almost unchal.

mysteriously took to flight.

In the next inove tha student. militia captured Mehtarlam in Laghman provtnce where Gulbadin Hekmatyar's Hezb-iIslami was based, biit were checked at nearby Sarobi, the last foot-hold of Hekmatyar, after Ahmad Shah Masood reached there

Till now Taliban have cap. tured areas peopled by domi nant Pukhtoons and ruled by maverick commnnders much to the disgust of conimon people. Alienation of the locals from their respertive warlords felicitated Talibain's gains having al most a free runover.

The disenclianted Afglians. longing for a sort of ordet and peace, more than welcoined Taliban with a hope to seo an end to chaos and anarchy.

Taliban's spectacutar victo ries have unnerved President Burhanuddin Rabbanil and shocked Hekmatyar who has been reduced to a farthing with no placy to hide in. Hekinatyar is the worst sulferer in the cur rent. War - in the entire Alghanistan ho has the tiny Sarobi.

Facing an imminent threat to Kabul, Rabbanl and Heknnatyar

\section{Taliban blitzkrieg}

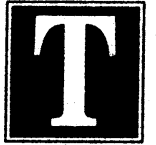
he Taliban blitzkrieg against the four provinces of the Eastern Shoora, capturing two of them and preparing to overnun the third, will place them closer to Kabul from the vulnerable east. Sarobi, Prime Minister Hekmatyar's headquarter, is already under air attack with daily bombing and shelling. If Kunar province falls, the Tajiban will be poised for a full fledged assault on Sarobi, beyond which is Kabul.

This dramatic advance by the Taliban evidently materialised after they rejected the neutradity proclaimed by the Eastern Shoora in the civil war in the country. The Shoora comprised representatives from most of the factions and distributed the important offices in the provinces under its control among its members by rotation. This had helped in overcoming the infighting which. was affecting the administration of the provinces. The Taliban had earlier kept clear of the Shoora's area" but the political developments required a change in policy.

The religious student militia was also under pressure to complete the task of overthrowing the Rabbani administration before the international moves to bring about a cease-fire in the country and seek a political solution to the conflict materialised. Iran, playing the role of the main patron of Rabbani, had succeeded in resolving the differences between Islamabad and Kabul. The Rabbani regime had also been rècognised as a de facto and de jure government of Afghanistan, even if its authority did not extend a few miles out of the capital. In such circumstances, the status of the Taliban would have suffered a demotion from that of equal players in the field to troublesome elements.

But it is quite likely that these sudden successes by the militia will not signal the end of the Rabbani administration. There is too much at stake for the various Afghan factions and external powers opposed to the Taliban to let them emerge as the masters of the country. Such an eventuality will drastically influence the geo-political situation in the regions abutting on Afghanistan. Iran particularly has been disturbed by the emergence of Taliban from the beginning, and made its displeasure apparent.

While Islamabad has constantly denied any role in introducing the militant students into Afghan politics, it has not at the same time expressed its concern over the manner the Taliban have been acting recently which has resulted in a massive influx of refugees into the country. The Pakistani authorities cannot be unmindful of the danger of religious students undoing the peace that existed in the area along the country's borders. The Taliban's successes might well turn out to be Pyrrhic victories causing more harm than good to Afghanistan.

THE NEWS INTERNATTONAD

FRONTIER POST 21 SEP 1996 


\author{
By M:B. Naqui
}

TALIBAN, the hardline Islamic students' army, seem to have resumed their apparently sweep-all advance in Afghanistan. The aim obviously is to choke off supplies from Pakistan to the embattled capital at least from the east and south; the western route is already under their control. That will leave it only the route from the north through Salang Pass. In the process they have captured Jalalabad and are advancing further.

Speculation on future prospects is natural. All Taliban supporters expect its further victories, mostly blondless, and eventual triumph. The immediate prospects are less rosy: war for Kabul is likely to be both bloody and lnng-drawn-out. For that matter, some expect the Jalalabad vic. tory to remain precarious for an indeterminate time - unless of course the Taliban are power. fully reinforced and helped by their patrons and suppliers, whoever they might be. Burhanuddin Rabbani's Kabul government, supposedly reinforced by the recent accession of Engineer Gulbadin Hlekmatyar as PM, has lost no time in blaming Pakistan's military intelligence agen. cies. Pakistan government's formal position continues to be unaffected: it is neutral. It claims to have left the Afghans to determine their own future - which is what they are doing. But internationally, fresh alarms are being sounded. It is hard (1) see who will feel encouraged and happy by this turn of events. The Iranians have, for their part, sent a peace delegation to the Taliban leaders post-haste.

The Iranian concerns over the possible final victory of Taliban can be taken for granted: It is sure to feel unhappy and threatened Threatened? Yes, it is likely to he alarmed on two counts: First, it is unlikely to approve of an Afghanistan that is ruled by such hardline (Sunni) Islantists. Not that they will let that hap pen without doing something or other to prevent it, if it is in their power. No one can be sure as to what assessment they make of the chances of the ultimate Talihan army's success, especially whether it can ever take over the non-Pushtoon areas in the north. It is likely that Iranians too share others' assessment that the ultimate Taliban victory can only divide Afghanistan along the basic ethnic faultline: between the Pushioon and non.Pushioon areas.

But the second ground for Iran's worry is Afghanistan's sectarian divide. The Taliban have shown themselves to be extremist Sunnis who would not give equal treatment to the Shia minority on principle. Taliban's final victory would be seen - and not only in Tehran - as the triumph of a bigotted and obscurantist force that will seek to extinguish such pluralism as did exist in the Afghan society.

Iranians of course are not the only ones to feel uneasy at the Afghan prospects. We can safely assume that almost all other powers would like to see Afghanistan remain a single state, reason ably united and hopefully at peace with itself. Among these one need not fail to count the US. The US has recently revived its active interest in Afghanistan. Its diplomats have been in contact with Taliban leaders, as with most others. What the precise American preferences are, in terms of geo-strategic thinking, remains hazy, perhaps they are humming and composing as they go along.

epartment statements cannot be compared so far above its stature in trying to impose a govwith what their strategic thinkers prescribe, that ernment of its own choice on Afohanistan, hov in this case are unclear. Powers not to be ignored are Russia and China, not to forget Afghanistan's northern neighbours. It is certain that none of them is likely to relish the idea of a Taliban-run Afghanistan, united, or, more likely, fractured. The fear of what is termed Islamic fundamentalism is fully shared by all the neigh bours of Afghanistan, except Islamabad's rulers. it is not insignificant that none of them has supported Pakistan's Afghan policy; indeed most have serious reservations on the subject, though they are discreetly silent. Also, there is India. Time was when India was number two donor to Afghanistan after Soviet Union, at least since 1965 when the Americans had thrown in the towel. Indian aid ended with the collapse of Dr Najibullah's government. The Pakistan-suppor ing governments after 1992 cold-shouldered India - for a time. India has returned and certainly has more influence on Kabul than Pakistan, even if it has no interlocuters else. where. For practical purposes in the immediate future, India can be ignored hecause it is not neighbour of Afghanistan and has few diplomat-

What is more likely is not a complete and overwhelming Taliban victory or of any other faction. It seems no one has the ability to keep Afghanistan reasonably united and run it efficiently, whether democratically or Islamically. A division, simple or multiple, is becoming ever more likely. The Taliban ascendency threatens to introduce an additional source of conflict: sectarianism.

ic sinews to bring itself to hear on Afghanistan. But in the evolution of world opinion, there would remain a certain input fróm India.

The Pakistanis, outside the' charmed circle that has been conceiving, executing and dominating the Afghanistan policy, can only be anxious about the prospects for their own country: there is the fear of the fallout from Afghanistan that might include a military dimension. The Taliban can re-train their guns further eastward; they might like to repeat the performance in Pakistan's own Pushtoon areas where the political infrastructure for it exists. Insofar as the politics of Taliban is concerned, few Pakistanis can relish its obscurantism and bigotry. What they stand for in positive terms, viz their perceived Islam, is not what can enthuse most Pakistanis - supposing that is their true moving force.

Pakistan has by its own actions blurred, if not virtually erased, the Durand frontier. Pakistan governments, not excluding the present one At any rate no one seems to be sure about the : hear. a heavy responsibility for what is likely American short- and mediun-term objectives. In happen to Afghanistan's integrity and unity. It this respect the credibility of the State possible to fault Islamabad for trying to punch ing to make it stick. Afghanistan is a bog. Two superpowers have rued the day they adventured superpowers have rued the day they adventured into Afghanistan: Britain thrice during the last 160 years or so and Soviet Union recently. Pakistan's objectives in Afghanistan have never been clearly and realistically defined.

Pakistan's interest in Afghanistan is under standable. There are so many commonalitie between the two countries; in some ways thei fates are interlinked. Pakistan needs ays their and strong Afghanistan that can sustain is independence. Pakistanis need Afghans' friendship and to be in conflict with them is inconceivable because of the ethnic commonalities between the eastern parts of Afghanistan and our Pashtun belt. A new interest has also arisen that may have ohsessed policy makers in Islamabad.

With Soviet Union's collapse and emergence of 15 Republics in its place, some mouths began watering in Islamabad on the prospects of the Central Asian states' foreign trade being routed through Karachi. But that is possible only when Afghanistan was united, ruled by a vigorous enough government that can keep peace and roads open. Since these conditions could not be created by post 1992 made-in-Pakistan governments, the prospect of a large transit trade through Karachi has remained a chimera. The basic flaw in all this was to suppose that Pakistan was the real victor in the Afghan war and it deserved to have a government in Kabul that was amenable in its advice. Which is how Islamabad's ambitious rulers felt cocksure that they can reorder Afghanistan as they pleased and manufactured an Afghanistan government. put it on a PAF C. 130 and installed it in Kabul.

True to their traditions, the Afghans looked askance at an imported government and eren its successors have remained political weaklings and a liability on l'akistan. Some of our econom. ic woes are due (1) the necessity of having in supply a considerable part of Afghan population with all its wherewithal.

Anyliow, Afghans move at their own pace and in their uwn way. llaving been denied a democ. ratic methodology to solve problems, they creat. ed their kings, dictators, foreign supporters and Pakistan, they are left with their own inherited devices: medieval minds, recently heightened Islamic consciousness and proliferation of armed militias run by rich and ambitious individuals, and all vulnerable to international intrigue So far Pakistan has not been directly hit by its pre. tentions of being a great power, except through the loss of the credibility of Durand line and the flourishing of heroin and gun cultures. But the potential for paying a terrible price continues to threaten.

What is more likely is not a complete and overwhelming Taliban victory or of any other faction. It secms no one has the ability to keep Afghanistan reasonahly united and run it effitiently, whether clemocratically or Islamically. A division, may be simple may be multiple, is becoming ever more likely. The Taliban ascen. dency threatens to introduce an additional source of conflict: sectarianism. Can anyone really visualise the northern areas, peopled they are by ethnic as well as sectarian ties, remaining happily in an Afghanistan ruled by Taliban? Or would Taliban's military proves simply subdue all the northern areas? simply subdue all the northern areas? Finally there is the question that needs to he posed clearly: Does a possible Taliban victory in Afghanistan augur well for Pakistanis?

At any rate, Pakistanis need to clarify their ohjectives and end their isolation on this ques.
tion also. 


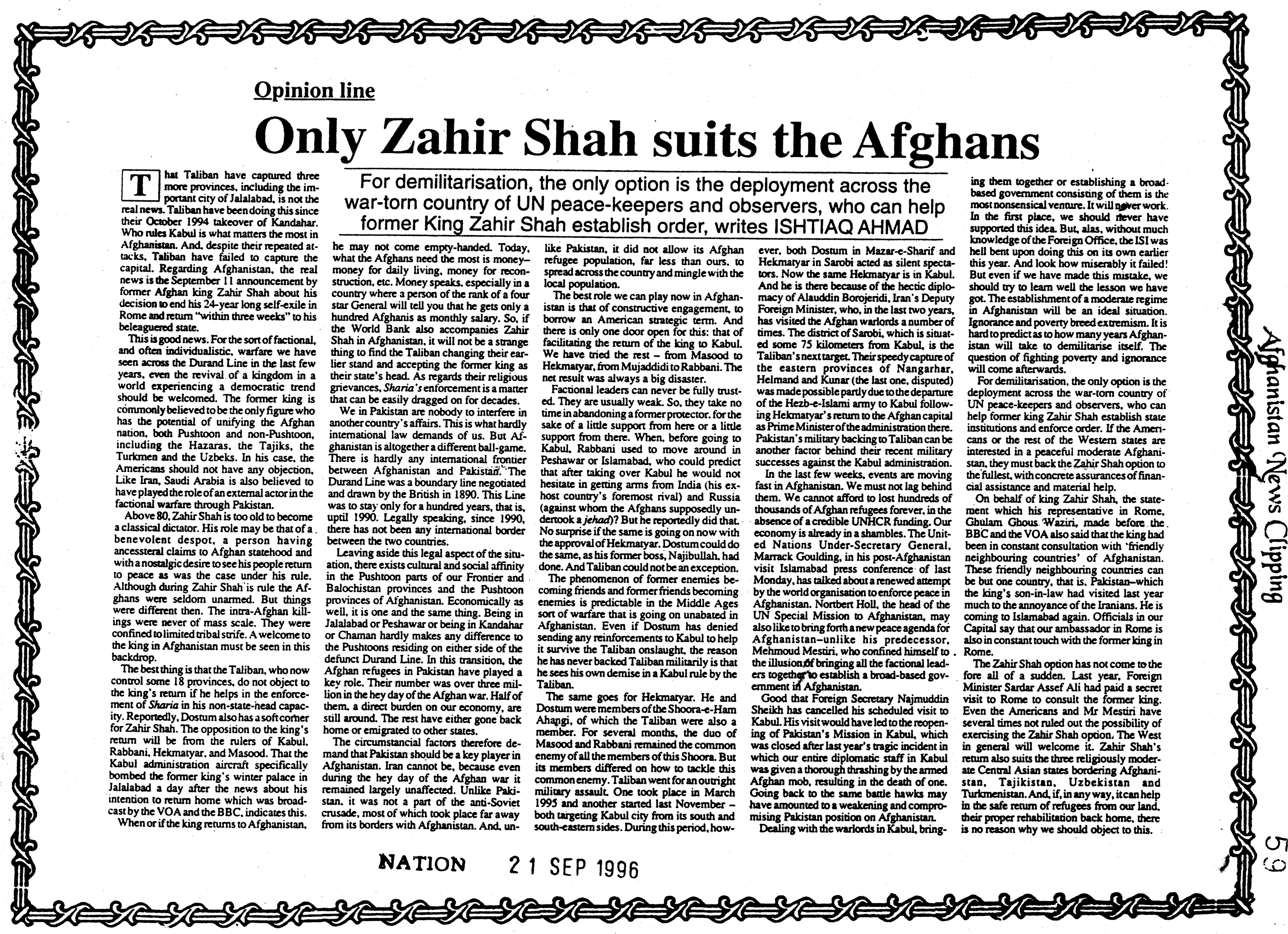




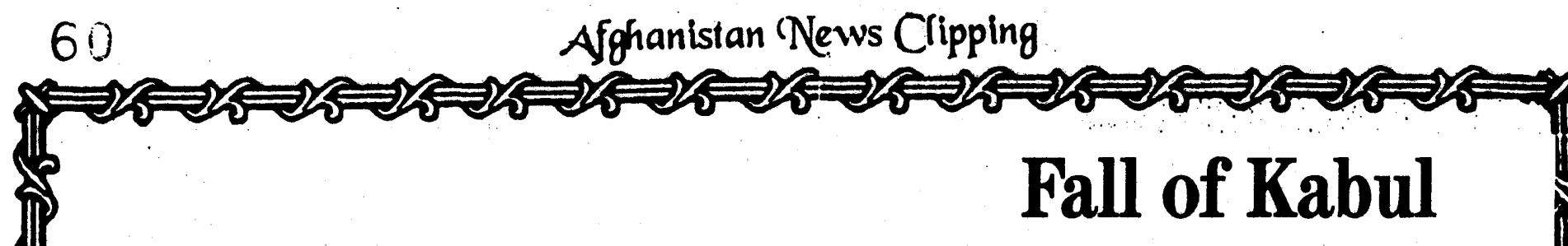

\section{Calling off Kabul visit}

THE last minute postponement of Foreign Secretary Najmuddin Shaikh's visit to Afghanistan has once again soured relations between Islamabad and Kabul. Although the Foreign Secretary has expressed his desire to "reschedule the visit at an early date", this appears unlikely given the rising tension. The visit, had it taken place, would have ushered in a new era of cooperation between the two sides as the re-opening of the Pakistani embassy in Kabul was on the cards. Relations have now once again been thrown into a state of limbo. At the heart of this latest setback lies the Taliban offensive which has resulted in their gaining control of two key provincial capitals, Jalalabad in eastern Nangarhar and Mehtarlam in Laghman. The fall of Jalalabad had elicited accusations from Kabul that Pakistan had helped the Taliban in the offensive A spokesman of the Kabul regime urged Pakistan not to interfere in the internal affairs of Afghanistan. Pakistan was quick to deny these allegations but the damage was done. Mutual acrimony had re-surfaced.

These and other rapid developments have again brought into sharp focus the confusion which appears to plague Pakistan's Afghan policy. If the efforts II to normalise relations with Kabul were anything to go by, a fresh Taliban offensive was the last thing that Pakistan could have desired. The dust on the Afghan battlefield was in the process of settling down; Iran had announced the II holding of an Afghan peace conference; UN efforts had picked up steam after $f$ the arrival of a new envoy and American interest - illustrated by a series of high-level visits - appeared to be increasing in the war-ravaged country. How was it then that the Taliban decided to scuttle all these efforts by launching a fresh offensive? Is it possible that the Pakistani Foreign Office came to know of the attack on Jalalabad after hostilities had broken out? If so, it does not speak well of our policy makers and their knowledge of what is brewing next door. But if the Taliban offensive has strangulated Pakistan's peace overtures towards Kabul, the postponement of the Foreign Secretary's visit may have made matters worse. Had the Foreign Secretary gone ahead with the trip, it would have had a balming effect on Kabul's acrimony and also symbolised Pakistan's determined efforts to maintain strict neutrality in Afghan affairs. After the postponement, however, the impression of Pakistan being proTaliban is likely to gain more credence, thereby further alienating Kabul. Reports of negotaitions between General Rasheed Dostum and Ahmad Shah Masood, though still unconfirmed, have also started ringing alarm bells in If Islamabad. If a loose alliance does materialise, it would am a result of too many severe blow to Pakistan's policy. This lack of dirtion invelvemt of the players pushing their own agendas in Afghanistan. The involved repeatedly Interior Minister and a number of other players hecause of the dichotomy and in the press. Blunders have occurred in the past because of the different direcsometimes trichotomy which has torn Pakistan's policy in differests lie vistions. At present, Pakistan appears clueless about where its interests lie vis a-vis Afghanistan. What is needed is some cool-headed reflection by the policy makers followed by a well-coordinated effort to salvage whatever is left of Pakistan's policy. Playing favourites has not paid any dividends in the past and it is unlikely to do so in the future.

\section{NATION 21 SEP 1990}

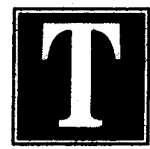

he Taliban completed their conquest of Kabul with a vicious display of violence by publicly hanging the last revolutionary president of Afghanistan, Dr. Najibullah and his brother. Both were under the protection of the UN according to a solemn agreement reached with the mujahideen government of the day. The assassination would give an insight into the type of governance that could be expected from a faction which came into prominence only two years ago, and little is known about its political background.

The fall of Kabul, however, was imminent once the student militia had pierced the defence parameters of the capital, and the much boasted retaliatory punch of the legendary Ahmed Shah Masood did not materialise. Rabbani and other leaders staged a "strategic withdrawal" from the city, which means they retreated to safety, allowing the Taliban an unexpectedly easy victory. They entered the capital without resistance and have since set up a 6-member interim council.

Pakistan, like several other neighbouring powers will be faced by the question of recognising the new power wielders in Kabul. Much will depend on how the latest conquerors will present themselves before the world regarding their credentials as being upto the task. Islamabad has accepted the fact that the Taliban now effectively control Kabul as well as twothirds of the country, while some other states, like Iran have condemned the capture. Kabul had become a bone of contention not only among the Afghan factions, but also among foreign patrons who supported or opposed the former ruler of the city.

The tragedy of Afghanistan resulted from the excessive interference by foreign powers from the day they got an opportunity to do so when the Saur revolution was staged. Since then it was open season on Afghanistan with any state meddling in Afghan affairs with impunity by sponsoring any one of the self-proclaimed mujahideen groups. The outcome was the internecine warfare among the Afghan factions that gripped the country after Dr Najibullah, the last PDPA leader had steuped down.

The Taliban were the latest entrants, who joined the game fully prepared and equipped and supported by foreign sponsors. After a dramatic advance which saw them overrun most of the country, eliminating many of the warlords, they reached the outskirts of Kabul. The fall of the capital was quick and came as an anti-climax to the massive thrust made against the entrenched defenders. The student militia became the new rulers of a country which has seen about half a dozen governments in the last two decades. There is no certainty whether it ends the suffering of the Afghan people, who have seen nothing else except unprecedented violence and destruction in the last four years.

THE NEWS INTERNATIONAL 28 SEP 1996 


\section{The Taliban on the march}

ALTHOUGH it is a foolhardy man who will make any firm predictions about the situation in Afghanistan, the latest news from the frontline (now established on the outskirts of Kabul) lends itself to the conclusion, even if tentative, that the war for supremacy in that wartorn country

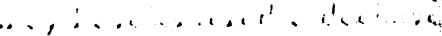
phasc. Inc: faliban have ras only captured the strategically-placed town of Sarobi, but exploiting that success they have at places breached the cutcer dofornces of Kabul where heavy fighting is raging. 'The Rabbani regime strongman, Ahmed Shah Masorsd, is said to be leading his troops in the battle to save Kabul. There are conflicting reports regarding the whereabouts of the prime minister, Gulbadin Hekmatyar. But this much is certain that the Taliban advance has been swift and that, barring any dramatic reversal, they are within striking or rather capturing distance of the Afghan capital.

The Taliban, of course, have been at the gates of Kabul before only to be pushed back by Ahmed Shah Masood's forces. But this time their assault on the capital has more of a method to it. In the past two weeks they have made massive territorial gains, capturing the three Afghan provinces of Nangrahar, Laghman and Kunar. Rather than sitting over their gains they have maintained a momentum which has surprised observers. Following swiftly on Tuesday night's capture of Sarobi, the Taliban pushed through the Lataband Pass towards Kabul. What is also remarkable about their advance is the lack of effective resistance and the warm welcome often extended to them by the civilian population of the areas coming under their control. This only goes to show that the people of Afghanistan are tired of war and the suffering and dislocation it has entailed. They are also sick of the squabbling Mujahideen factions who, instead of striving for peace, have turned the country into a cockpil of their petty rivalries, thus adding to the sufferings of the people. In this climate of fear and fatigue the Taliban, so it would appear, deliverers who would be able to put an end to the fighting and restore peace and order to the embattled country. It is a measure of this sentiment that so far the Taliban's major victories have been won without much bloodshed, the opposing sides either melting away or preferring to go over to the at if il ' J alilun

ince Rarirari regirne, ri course, is shifting the blame for its reverses onto the shoulders of Pakistan, which it has accused of helping the Taliban. It has also called for a mecting of the security Council to discuss the Afghan situation. But the plea it is taking is specious if only because its troubles are largely selfinflicted and not by any stretch of the imagination the handiwork of Pakistan. Why did President Rabbani not give peace a chance and why was he not serious about the UN-inspired efforts to broker a peace settlement? He preferred to hang on to Kabul by the sword. And it is by the sword that his regime, beleaguered and besieged, now faces its most serious threat. It is easy to say that peaceful attempts at a settlement should still be tried and given a chance. But at this late hour there are precious few grounds for entertaining such fond hopes. The Taliban have not taken any of the peace initiatives seriously before. They are not likely to do so at a time when victory seems to be within their grasp.

It is important to remember that the Taliban are the products of the frustration swirling in Afghanistan. If peaceful conditions in the country had been restored after the fall of the Najib regime, there would have been no Taliban. But when the erstwhile Mujahideen leadership fell a prey to squabbling and mutual jealousies, the Taliban appeared on the scene as an alternative to a discredited order. Cynical though it may be to say so, Afghanistan's best hope now lies in a clear decision on the battlefield one way or the other. Otherwise, if out of the fighting now raging around Kabul another stalemate is born, it takes no special wisdom to see that the misery and agony of a people heartily sick of war and strife will be prolonged. 


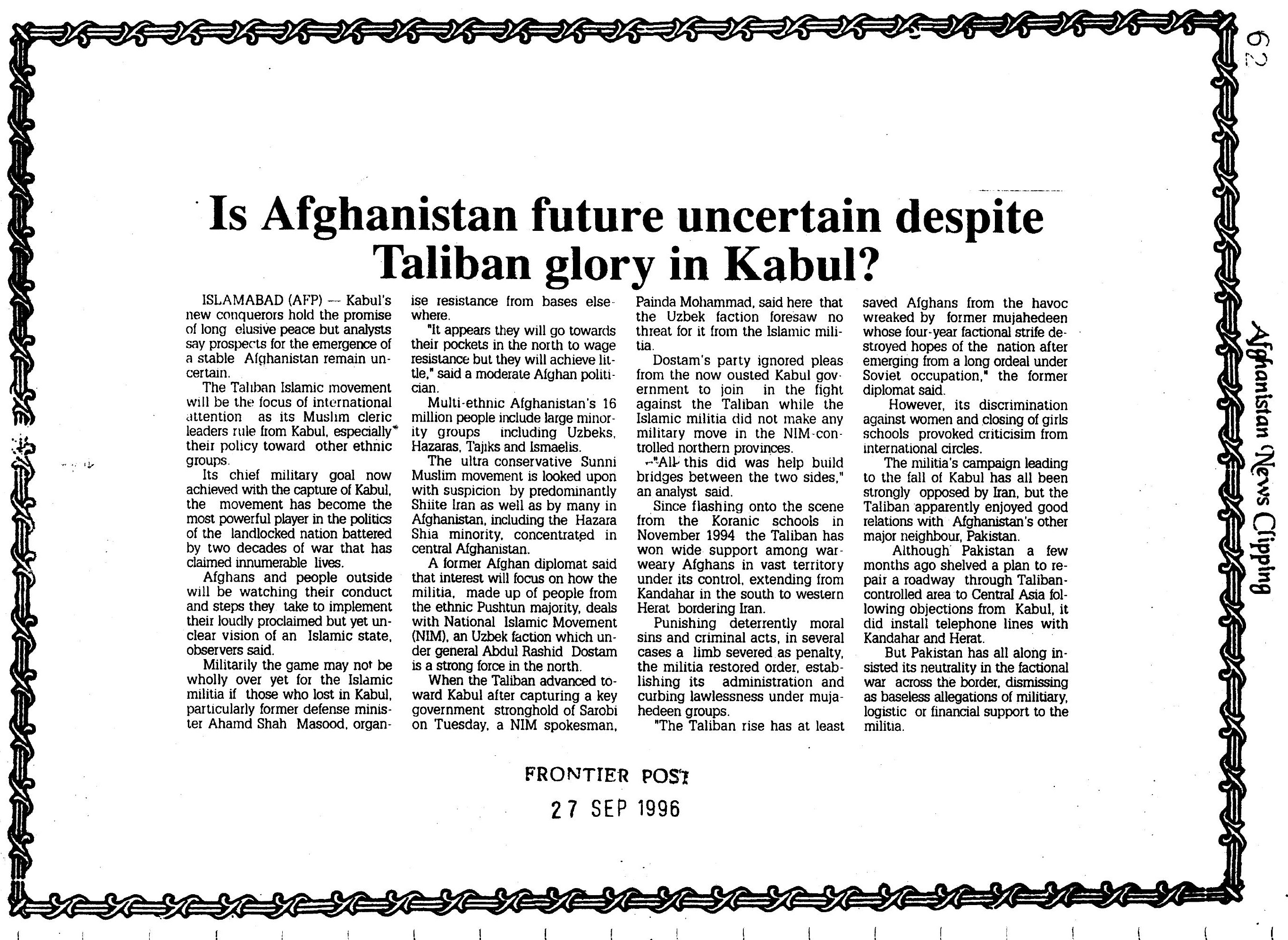




\section{Madness in Kabul}

By FAZULLAH JAN

Former Afghan president $\mathrm{Dr}$ Najibullah, his brother and other comrades were the first victims of Taliban's caprice and monocular wrath who were summarily executed and hanged in the most ignominious way on Friday.

Dr Najib, who was kid. napped from the Uniter Nations compound in Kabul before being killed, will be kept hanging in a public square for three days which is some thing unprecerdented in the civilised world.

The treatment Taliban meted out to Najib is sheer madness on the part of the religious charlatans which cannot be condoned and will have lar reaching consequences. 'The signals emanating trom the rapped Kabul are demonising Islam which was not done even by communists.

The justification being given by Taliban that Najib had been condemned condemned

\section{Comment}

in absentia is as lame as their existence. Is Taliban shoora empowered to condemn some one to death for farcical reasons of betraying Islam?

Taliban have yet to prove that how and when Najib betrayed Islam, and why he was not tried in a court instead, giving him the right to refence.

Taliban's capricious acts. which are bringing a bad name to Islam, have drawn due pub. lic indignation and worla-wide condemnation. Islam is a religion of restraint and peace very close to human dignity and honour.

The way Taliban are asserting themselves is wrought with dangers for the region in general and Alghanistan in particular. Reasonmg and diplomacy are unknown to them; they know the only languaye of Byzantuse era punishment.

Though Najib was killed by Taliban, the UN cannot escape responsibility for this ignominlous event which the world body could have easily avoided. The ex-Atghan president had been shelterng in the UN of. hoe singes lathe whall he lolin.

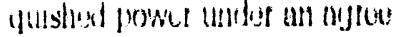
voy. broty. again. ment with then UN special en-

The UN evacuated its staff from Kabul well before Taliban stormed into the city, and assured Najib of his safety and security which has been nonexistent in Alghanistan since long. Verbal condemnations by the UN will not undo what has been done.

Najib's barbaric execution has further exposed the impotency of the world body which under the 1992 agreement was bound to protect the former president by facilitating his safe exit from Kabul.

So week the UN has become that 36 hours after Najib's execution, it has yet to retrieve his

And the most intriguing was the Pakistan's stance vis-a-vis Najib's killing and new dangerous developments in Afghanistan. Islamabad has so tar made no statement on the gory incident and is impatient Atrings once

We have alienated Iran and Central Asian states, besides Russia, by supporting a force which is going berserk day by day, provoking fears in minority ethnic groups in Afghanistan.

Sanity demands that Pakistan and other regional countries should prevail upon tho Taliban leadership that peace restoration and reconstruction of Afghanistan demand intra-Alghan cooperation. Taliban's bid for a violent and bloorly solo flight in the tribal entity will cause further schism in the fragmented Afghan society.

Every faction leader has a dependable following among his respective community. Alienating these faction leaders will tantamount to alienating a particular ethnic group.

Najib's killing has so far caused only grumblings mainly due to the fact that he was a Pakhtoon and murdered by Pakhtoons. Any such a felony with peopile trom any other ethnic groun may unleash further bluoidshoid, makling hopar of a libiling peaso a lia? ary.

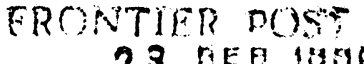

$$
28 \text { SEP } 1908
$$

AFTER the sudden, unconditional fall of Kabul before a slormy invasion of the Taliban and a strategic withdrawal of President Burhanuddin Rabbani and Prime Minister Gulbaddin Hickmatyar the question once a!gain looms large whether the long-drawn internecine wirlare would end and peace and stability relurn 10 Alghanistan. The Taliban, who now control two-thirds of the country, have summarily hanged former president Najibullah, who was under the protection of the UN for more than four years, and his bodyguards at the gate of the presidential palace and formed a provisional Islamic slate by appointing a sixmember 'shoora' headed by Mullah Mohammad Rabbani. The rise of Taliban militia from the ashes of war-ravaged Afghanistan after a successful freedom fight against the Soviet occupation and consequent struggle for powcr by varied ethnic and religious groups in a short span of time is quite phenomenal and it culminated with the capture of Kabul on Friday. II. no doubi, can be regarded a signal of triumph for them but it also leaves many questions unanswered in its wake besides a streak of death and destruction. Viewed in the backdrop of complex tussle for power, it seems the fate of the country still hangs in the balance and it depends on how the Taliban consolidate their gains which they have won on the battlefield. Will they show magnanimity to share power with other leading elhnic groups with a view 10 fostering enduring peace and culminating, once and for all, the ordeal of the people who for almost two deeades have been living under the ominous shadows of death? At present the Taliban, in the first flush of their successes, seem to be in the mood to go at it alone. Even il' they show the spirlt of accoinniodation by luring some "ther stray groups to their sides, it does not ensure lasting peace, for previously al- liances belween various factions were made and hroken as easily as they were formed. And then one cannot ignore influences and interference of geopolitical regional powers that matterPakistan, India, Iran and Russia - which have visible stakes, political and econom$i c$, in the country and are monitoring the current developments very closely. They will be overtly trying to curry favour with the new selup or covertly destabilising it according to their own perceplions of the change. While Shi ite Iran is quite suspicious of the staunch Sunniled force domination, Russia naturally will be very apprehensive of the establishment of a lundamentalist government in its vicinity that its fallout may compound its problems which it is already facing in its Muslim-majority areas. On the other hand, Pakistan is soon sending a high-powered delegation to Kabul to establish contact with the Taliban shoora in Kandahar which strengthens the view that the Taliban government is more friendly towards Pakistan.

No doubt, peace is likely to reign in most part of the country, barring the region in north which is still under the strong control of General Dostum and the territory where the deposed rulers are regathering their battered forces for another round. But how long the fragile peace will hold? The Afghans will be watching the conduct and :teps the Taliban take to implement their avowed ideas of Islamic state. The people of Kabul are quite enlightened and they may not like a very rigid religious discipline of the fundamentalists brand. What kind of Islam the Taliban are imposing is manifest in the order that discriminates against the womenfolk who are barred from attending offices beside closing down of the girls schools. The Taliban are being projected in a bad light internalionally by their retrogressive step.

ERONTIER POST 


\section{From Our Correspondent}

PESHAWAR - Opening of Salang Highway, a main route connecting Central Afghanistan with northern provinces, will likely to reduce the existing economic tension of people from both parts of that war revaged country.

In the light of an agreement signed by the leaders of National Islamic

Movement of Rashid Dostam with a five-member delegation of Kabul headed by Hizbe Islami's Humayoon Jareer, the highway was opened on August 29 last. Its reopening was conditional but at eleventh hour, the Kabul regime had refused to release the prisoned pilot Hafeezullah. In the light of said accord, both the sides were agreed for exchanging 20 POWs, 10 from each side. Rabbani-led Kabul government has agreed for release of Pilot Hafeezullah Khan, belongs to Sulaiman Khel tribe with exchange of Maulvi Zahir, a close supporter of Ahmed Shah Masud.

During a day long stay at Takhta-iSang and Pull-i-Farashtagaan. in northern parts of Afghanistan. this correspondent had witnessed that Rashid Dostam's Northern Shura had brought all 10 prisoners including MaulviZahir While from the kabul side, Hizbe Islami's Engineer Qutabud Din Hila was present only with nine prisoners and unable to bring pilot Hafeez. The reluctance on the part of Kabul administration regarding release of Hafeez, the exchange of POWs couldn't take place. But the Northern Shura has proved its loyalty to the accord and its leaders included Gen. Majid Rozi and Abdul Qadar Dostam declared unilateral re-opening of Salang road included a three kilometres long tunnel.

With announcement of Gen. Majid Rozi and Qadar Dostam, hundreds of vehicles stranded at northern province rushed towards the Salang route to reach Kabul. Hundreds of vehicles passed between Kabul and Mazar-iSharif in the last four days, enabling the war affected people from both parts of Afghanistan toget a relief from increasing price-hike and economic uncertainty. In Mazar-i-Sharif, it was learnt that almost vehicles who arrived in the city and left for Kabul were stranded since January first, 1994.

As a result of closure of the Salang Highway for a period of around three years, the business and trade sectors of both northern and Central provinces was paralysed but its closure posed bad impacts on Kabul government as well as on its civilians. Now the road has been opened and both the sides could easily transport goods between the two parts of Afghanistan, being governed by rival groups. Gen. Abdul Rashid Dostam and his other associates, during their talks with a group of newsmen from Peshawar have claimed that they opened the road keeping in mind economic problems of the civilians residing in central parts of their country.

The opening ceremony of the Salang highway was inaugurated by four cyclists from Kabul who toured the northern province with a view to convince the Afghans for restoration of peace. While HALO Trust, an NGO, sponsored by the European community, completed the demining process in a period of around two months. However traders at various parts of Afghanistan including Mazar-iSharif, Pull-i-Khomri, Doshi, Shabarghan, Balkh and other places have jubiliated reopening of the road. They were hopeful of minimising prices of the daily use goods. Likewise, they were confident of transporting the goods between the two parts of Afghanistan.

\section{Afghan council to welcome peace restoration plan}

\section{From Our Correspondent}

PESHAWAR - Peshawar based Afghan Council for Peace and Reforms in its meeting held with Dr. Faroog Azam in the chair, urged the neighbour countries to stop interference in affairs of Afghanistan and help restore peace in Afghanistan.

The meeting attended by a number of leading members and leaders of the council discussed in depth the proposed regional conference to be held under the auspices of Iran. The ACPR welcomes every national. regional and international attempt to find a peacefu solution to the long conflict, it re solved.

The Council decided to establish contacts with participants of the proposed Tehran Conference included UN Secretary General. Dr. Norbert Holl. Secretary General of OIC, foreign ministers of Tajikistan, Uzbekistan, Turkmenistan. Iran and Pakistan. Purpose of the proposed contacts is to convince the neighbour countries for stoppatge of interference in affairs of Afghanistan as well as for enabling affected Afghans to sort out a negotiated solution to the conflict.

\section{Zahir Shah announces end to 24-year exile}

From Behroz Khan

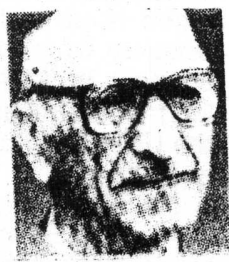

PESHAWA R Former Afghan king Zahir Shah Friday announced to end his 24-year exile in Rome and return

Afghanistan in the near future.

"Zahir Shah intend to return to Afghanistan within three weeks time," Ghulam Ghous Waziri, the Romebased representative of the former king told the $\mathrm{BBC}$. Issuing a communique from Italy, which was broadcast by Voice Of America (VOA) and the $\mathrm{BBC}$, said Zahir Shah has decided to return as the people of his country want his come back. Waziri did not mention the specific date of Zahir's return

Taliban spokesman Masoom Afghani told The News from Qandahar that the student militia was ready to welcome the ex-monarch as an ordinary Afghan and not in the capacity of the state's head. "We have our own Amir-ul-Momineen.

Another Taliban spokesman Muttaqi told VOA "every one is welcomed by Taliban who can help in the implementation of Islamic order in Afghanistan. Zahir Shah should also support us as our leader has restored peace," Muttaqi said.

The representative of the former king said Zahir Shah was in contact with almost all the major groups in Afghanistan and efforts were being made to convince his supporters as well detractors. Waziri said Zahir Shah was also in close contact with the 'friendly' countries who were supporting him for the restoration of peace.

The Afghan government sources in Pakistan, however, refused to comment on the subject without consulting Kabul.

Taliban leaders as well as Gen Rashid Dostum have a soft corner for Zahir Shah in the past. Kabul govt, specially Gulbaddin Hikmatyar and former Afghan defence Ahmad Shah Masood were hitherto among Zahir Shah's strong opponents.

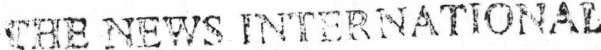

\section{SEP 1996}




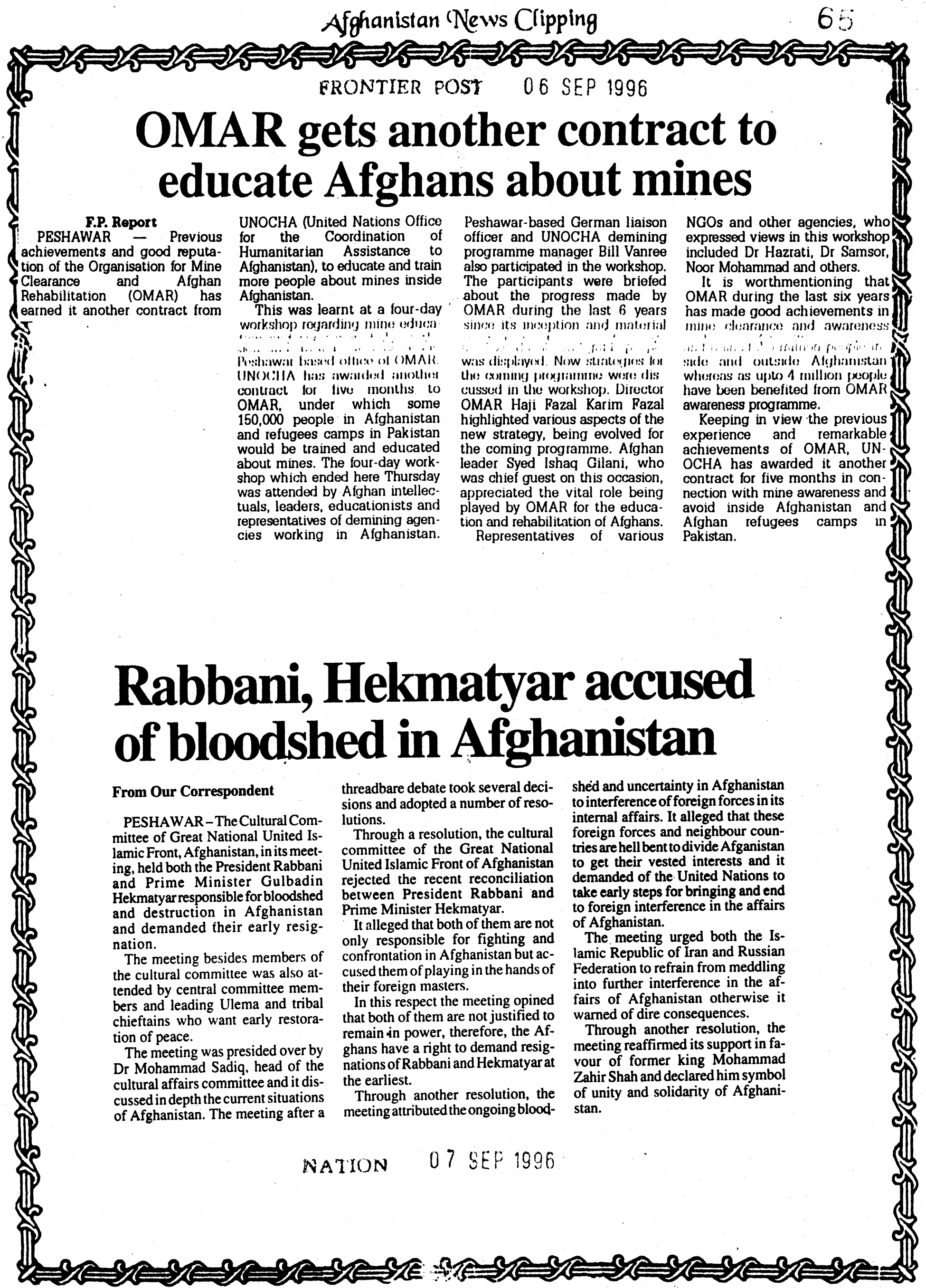




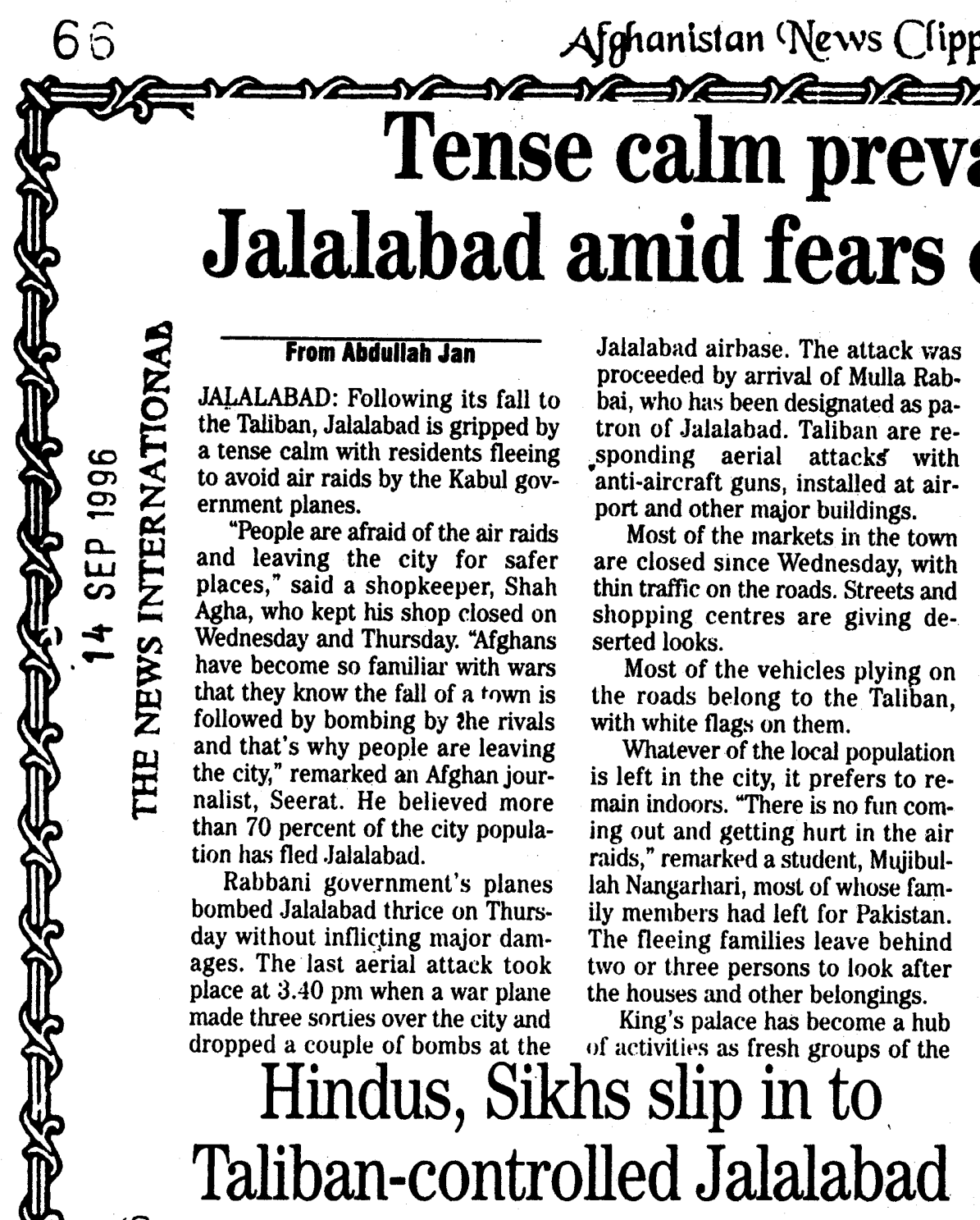

$\stackrel{0}{\circ}$

으

a

U

18

-

justice. We will return all the proper-

ties of the non-Muslims to them, " a Taliban leader Maulavi Faqir Ahmad told The news from Jalalabad. Both Taliban and the Pakistani border guards at the Torkham confirmed that a sizeable number of people belonging to the minorities were seeking permission to cross into Afghanistan every day.

"Protection of the lives and property of the minorities was the duty of the Muslim rulers," said Maulavi Faqir Ahmad adding that according to Islam and Shariah weaker and hapless citizens whosoever they were should be rescued and compensated. Taking away the personal property from the minorities was by no means acceptable in the holy religion or the existing customs of the Afghan society, he said.

-Taliban will not capture the houses of others, even of their enemies. Our duty is to take such occupied properties back and return it to their-real owners," the Maulavi said. Taliban sources informed that a joint on Taliban leaders in Jalalabad and sought their help to reclaim ownership to their lands, houses and shops.

More than 500 families were residing in Jalalabad city the time Mujahideen took control of Nangarhar in April 1992 occupying most of the business. They were cloth merchants, general store owners and had an equal participation in trade, carpet and fruit business but their bad days started with the removal of $\mathrm{Dr} \mathrm{Na}$ jibullah government in Kabul forcing a large number of the community to leave Afghanistan.

Their hope to co-exist with the mujahideen was shattered as a Hindu temple was burnt in Jalalabad and their property was occupied by local commanders. Disappointed by the prevailing situation, a large number of the families left for India while the rest settled in Peshawar or elsewhere in Pakistan. Very few of the families stayed back and braved the odd living condition. The fate of the minorities in Kabul was not much different from them as their shops were looted and houses gutted due to the factional fighting among mujahideen groups for the control of Kabul. delegation of the minority also called
Taliban and those coming from the front-lines reach the palace and get instructions about the future assignments. Locals also storm the palace to get latest information about the war. "Palace has become the control room. You can have latest information from here," said a local, Waliullah, who had come to Palace to know about the advances of Taliban against the Kabul troops. Jalalabad currency exchange mar. ket was yet another busy place where great hustle and bustle was witnessed on Thursday.

Those leaving Jalalabad are either going to the far-flung villages of Nangarhar province or heading towards Pakistan via sealed PakAfghan border at Torkhum. Hundreds of families that fled Jalalabad are stranded at Torkhum on Afghanistan side.

Most of these displaced families have erected temporary tents along the Torkhum-Jalalabad Road near the border.

\section{Qadeer wants no bloodshed}

ISLAMABAD (AFP) Haji Abdul Qadir, former governor of the eastern Afghan province of Ningarhar said Friday that he had surrendered control of the key city of Jalalabad to the Taliban militia to avert bloodshed.

"I had all types of weapons, guns, tanks bombs and rockets.I could have engaged the Taliban" in heavy battle, Qadir said in an interview with Pakistan television. But he said "I know the Afghan people do not want fighting. They want peace and I decided to surrender to prevent bloodshed."

\section{BRONTIER POST}

$$
14 \text { SEP } 1996
$$




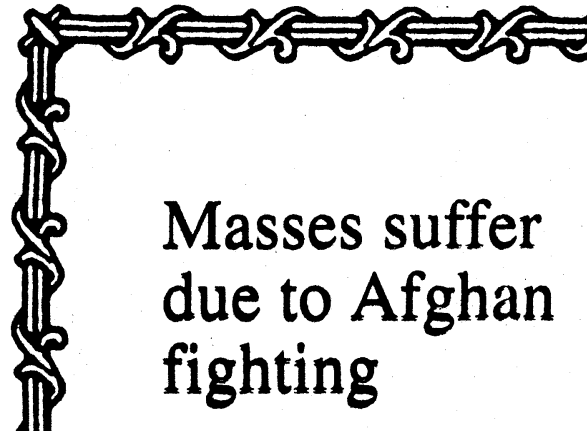

From Our Corrospondent

PESHAWAR - Due to the lack of a centralised authority in Kabul as well as confrontation amongst the warring factions in Afghanistan has forced its people to face worst kind of socioeconomic problems in all over the world.

A local Pushto daily, quoting an Afghan NGO report in its report provided detail of those unfortunate Afghans who are living behind the bars on minor crimes. It states that more than 600 Afghans including women, children and young boys have been in various jails of Pakistan, however majority of them are in central jails of Peshawar and Haripur.

Ironically, since resignation of former president Dr Najibullah in April 1992 last, responsible Afghan diplomats have never bothered to establish contacts with the authorities concerned for keeping record of the Afghans imprisoned in Pakistani prisons. Before establishing Islamic government in Kabul, almost Afghan diplomats, particularly the Peshawar Consulate General had kept a complete record of the prisoners in Pakistan. Even in 1989, a former Afghan Consul General had addressed letters to the Amnesty International and Special Envoy of the United Nations for Human Rights about 14 Afghan prisoners, apprehended under terrorist and subversive charges . by the Pakistani authorities.

The report added that the Afghans who are living in various jails of the province were facing criminal charges. While a limited number of them were arrested by tribal agencies under Frontier Crimes Regulations. Such type of refugees were apprehended from those camps, exist in the tribal belt. Besides adult prisoners, a number of children are also living in prisons with their parents. Quoting volunteers of the Afghan NGO, the report states that these Afghan prisoners are being maltreated by the jail authorities. Some of them have been waiting for trials for the last several years.

\section{NATION}

10 SEP 1996

\section{Afghan NGO holds literacy day function}

From Our Correspondent

PESHAWAR - Like other government and non-government organisations, the Basic Education for Afghan Refugees, (BEFAR), in connection with the Literacy Day has arranged a function in its office at Rahat Abad, Peshawar on Tuesday:

The function attended by Afghan refugees and educationists, residing in Peshawar, was addressed by Mir Abdul Malik Hashmi, Prof. Mohammad Rahim Elham and others.

Mir Abdul Malik Hashmi, literacy Coordinator of the organisation highlighted its services and contribution for the welfare of Afghan refugees in all over NWFP. He reminded that the BEFAR started its function in 1992 and so far it had imparted training to around 700 instructors skills to almost 24,000 male and female participants. The participants have been issued certificates in this respect.

Hashmi further said that BEFAR implements full literacy programme in three phases by keeping in view its specific methodology and has compiled three text books. He said that the NGO's services are being popular amongst the Afghan refugees in all over the frontier province. He said that due to fighting and bloodshed in Afghanistan for the last 17 years, majority of the Afghans particularly the youngsters were deprived of education facilities, therefore, the educated Afghans need to help the war affected countrymen in this struggle.

Prof. Dr Mohammad Rahim Elham. addressing the function highlighted importance of literacy in the modern Afghanistan.

At the end of the function, a documentary film regarding activities of the BEFAR literacy was shown to the participants.

\section{NATION}

\section{SEP 1996}

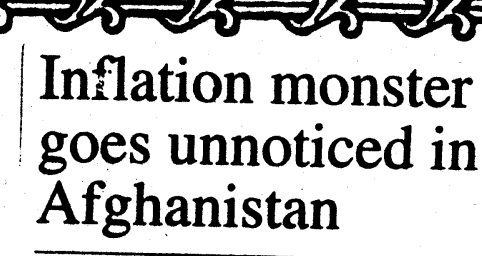

By Fahd Husain

ISLAMABAD - Amid the thunder of guns and roar of planes in warravaged Afghanistan, the monster of inflation is going unnoticed. The Afghan currency, Afghani, continues to lose its value in the open market as a result of which prices of essential commodities are soaring to alarming levels.

According to UN High Commission for Refugees (UNHCR) figures, the Afghani has dropped from Afs. 15,000 in June 1996 to Afs. 18,000 per US dollar in August 1996. There are no indications that this slide is about to stop. Prices of essential items vary from city-to-city (see table below).

These problems have been compounded by food shortages which have further shot up prices. It was with this in mind that Prime Minister of Af-

- Gulbadin Hekmatyar had asked Prime Minister Benazir Bhutto to provide food and other items for Afghanistan.

As a follow-up, an Afghan ministerial delegation had visited Islamabad last month to work out the details. Pakistan had stated clearly that it would not be donating these items but selling them. The mode of transportation had also been chalked out by the two sides. The opening of the Salang Highway for public traffic after three years on August 29, eased pressure and according to UNHCR an estimated 100,000 people have used the highway. The KabulJalalabad Road was also open for traffic till the fall of Jalalabad at the hands of Taliban last week.

Various heads of the UN relief agencies have been calling on the Afghan Prime Minister in recent days to apprise him of their efforts to provide humanitarian and relief assistance to the people of Afghanistan.

\section{NATION}

\section{SEP 1996}




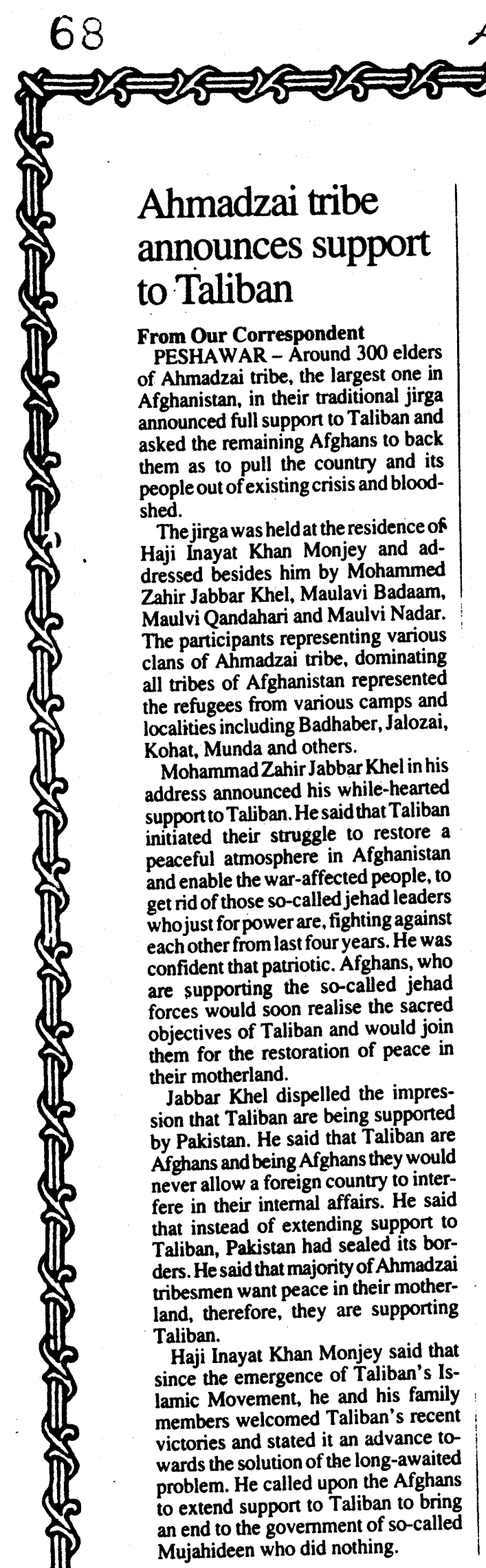

NATION

22 SEP 1996

\section{Afghan conference to rehabilitate livestock}

ISLAMABAD (PR) - While we hear disquieting news of intensified civil war in Afghanistan, some 15 Afghan animal health officers get together at Islamabad for upgrading their livestock expertise Livestock sector is an important income and nutrition source in the rural areas of Afghanistan.

A four-day conference for Afghan National Professional Project Personnel (NPPP) is organised by the Food and Agriculture Organisation of the United Nations (FAO) for September 22 to 25, for Afghan Animal Health and Production Officers who have come to Islamabad from many parts of war-torn Afghanistan, including Jalalabad. The conference is held under he aegis of the Animal Health and Livestock Programme for Afghanistan, which is funded by UNDP and implemented by FAO.

This FAO/UNDP programme is the largest veterinary and livestock production assistance scheme in Afghanistan. The programme promotes the development of a self-sustaining basic animal health system, with establishment of district-level Veterinary Field Units. The programme has so far established 244 veterinary units. Through these programmes, the NPPPs provide services which consist of vaccination, deworming, treatment of various livestock diseases inside he country. The programme is also aimed at the promotion of greater involvement of women in rural development and poultry production inside Afghanistan.

Mr. T. Kimoto, FAO Representative in Pakistan, mentioned in his opening remarks that he was pleased with the fact that Islamabad offers a timely and convenient venue for this Afghan conference, which is otherwise difficult to be held in Afghanistan for logistic constraints.

These Afghan livestock officers are returning to rural areas of Afghanistan as soon as the conference is over, in order to continue to provide assistance and services to farmers and village people.

\section{FRONTIER POS?}

\section{SEP 1996}

\section{War brings Afghan currency rates down}

\section{By Ahmad Hassan}

PESHAWAR, Sept 16: Afghani currency saw a downward trend on Monday with reports that Taliban militia had not succeeded to overrun Kunar province and their positions in Jalalabad were bombed by Kabul jets.

The Afghani had touched new heights against Pakistani rupee on Friday and Saturday with Taliban militia forces successful advances towards Kunar province after their taking over of the Nangarhar province.

According to the market report, the Afghani which stood at the lowest of 100,000 against Rs 170 Pakistani, before Taliban's advances against Kabul government had risen to Rs. 270 per 100,000 last week when Taliban militants over-ran last positions of government controlled areas in Paktia province.

It again rose to $R s 312$ per 100,000 when Taliban tonk the control of Nangarhar on Wednesday and then touched its peak on Friday and Saturday with the reports of Taliban's successes in Kunar province.

The Afghani, however again slumped and closed at Rs.312 on Sunday when reports said that Taliban were still not in control of Kunar.

\section{DAWN}

\section{SEP 1996}




\section{About 80 vehicles being smuggled daily from Afghanistan into Pakistan}

\begin{abstract}
From Rahimuliah Yusufzal
PESHAWAR: About 80 new and reconditioned vehicles imported from the UAE cross the Afghan-Iran border at Islam Qilla to enter Afghanistan for onward smuggling to Pakistan every day.

This was revealed by Afghan border officials to this correspondent during a recent stopover at Islam Qilla on the way to Mashhad in Iran. A large number of such vehicles parked at the border town testified their statement.

Afghan and Pakistani traders involved in the business told The News that they buy the vehicles in Dubai and ship then to Bandar Abbas before they are driven to Dogharum fore they are dring to Dogharun, the last Iranian village on the border with Afghanistan. Despite the tense relations between the Iranian government and Taliban, who control Herat province and rest of southwestern Arghanistan, border officials from the two sides appeared remarkably cooperative with each other in allowing transportation of these vehicles across their conmon border.
\end{abstract}

Afghan border officials and their Taliban bosses in average about 80 vehicles of every description - motor cars, coasters pick-ups, wagons, minibuses and luxury jeeps - daily enter Afghanistan from Iran. They said an other 100 trucks carrying foreignmanufactured goods ranging from to seaps to perfumes and from television sets to refrigerators also cross over from Iran into Afghanistan daily. They said an overwhelming number of these vehicles and goods are destined for Pakistan.

According to the traders, the vehicles and goods are transported rom Islam Qilla to Herat and after mecessary customs formalities are taken on the badly damaged road to Kandahar for onward delivery in Pakistan. The Taliban administration customs and taxes aren't much and their strict security measures ensures a very safe business for the traders and smugglers. Still the vehicles and goods-laden trucks drive in caravans on the Herat-Kandaha road for security reasons. From Spin Boldak the Afghan town Coldak, the Arghan town facin Chaman in Pakistan's Balochistan province, the new and reconditioned vehicles find their way through different routes to Pakistan. Business is booming because resourceful people are able to prepare both fake and genuine registration papers for the vehicles and are able to avoid payment of customs. Thus they take possession of expensive vehicles at possession A their original price in Pakistan. A large number of these vehicles enter Pakistan through NWFP. It is thus no wonder that motor-bàrgain centres have mushroomed in Afghan border cities like Jalalabad and Khost to meet the insatiable demand or non-custom paid vehicles in Pakistan. Alerted by newsp the NWFP government authorities the NWTP government authorities took measures to seize such vehicles. Official sources told The News that about 76 vehicles, mostly moto cars and reconditioned vehicles have been impounded during the past six months to one year. Most of the seizures were made in Kurram, North Wariristan and South Waziris $\tan$ agencies and Frontier Region Tank and Mohmand agency. The Tank and Mohmand agency. The Customs department was then asked to evaluate the seized vehicles. "The
Customs have already evaluated 33 vehicles while the remaining 43 wer currently being evaluated," informed a senior government official.

However, the Customs evaluation is being viewed here as being on the higher side As one provincial govigher erm cars of late 80 s models were being evaluated for payment of in 200,000 to 250,000 which he said was lot of money for cars damaged in transportation and some of whose parts were missing. That is why the NWFP services and general administration department, which had shown interest in buying these vehicles, still hasn't made its mind about the pur chase.

The seizure of these 76 non-customs paid vehicles by NWFP government apparently constitute only a small percentage of vehicles which have been brought into the province and are plying on roads all over the country. After all, where do all the vehicles go consic an average of 80 of them enter an fghanistan daily from Iran and al most all of them find their way into Pakistan.

THE NEWS INTERNATIONAI

25 SEP 1996 


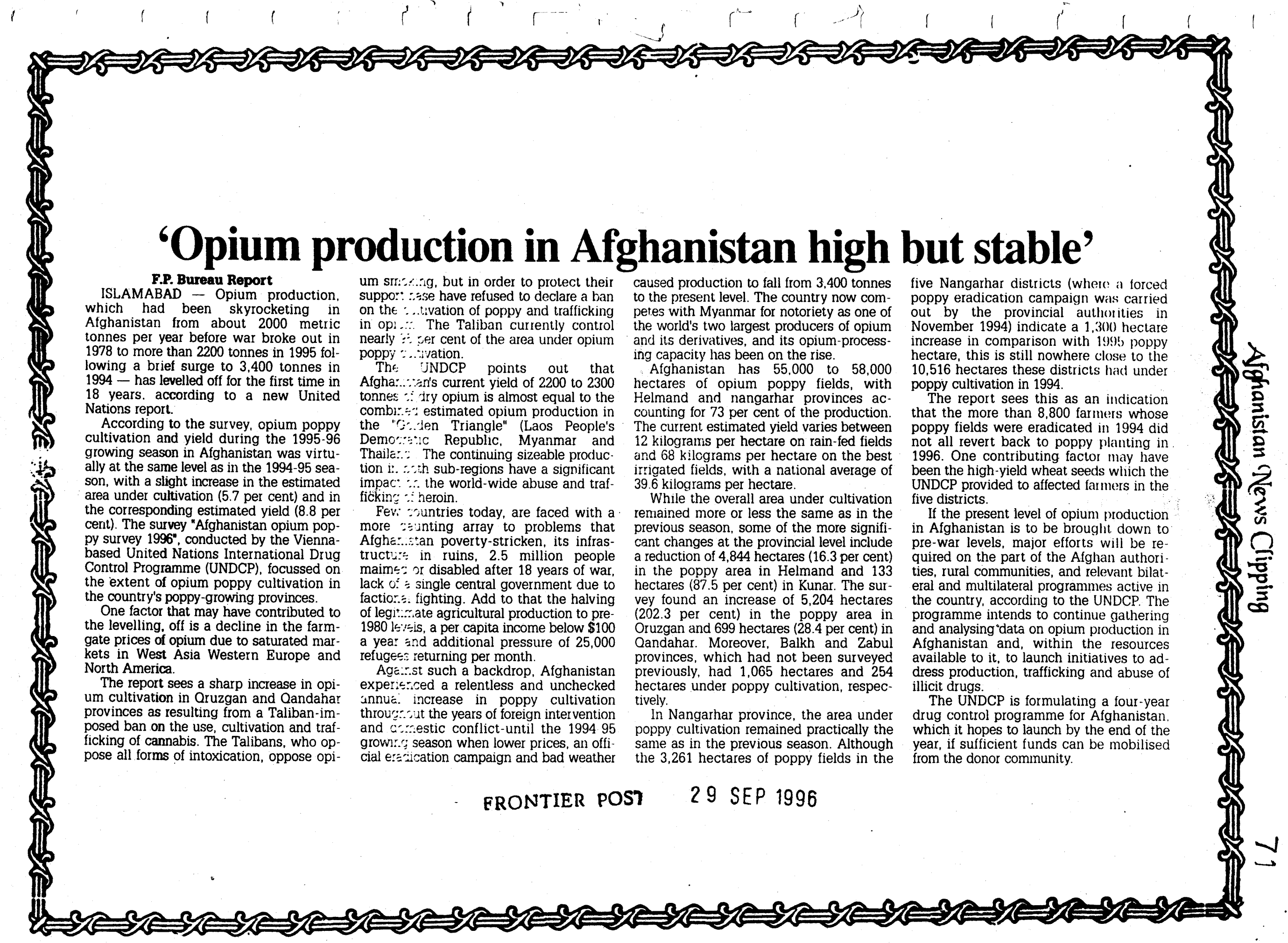




\section{2 $\int_{0} \begin{aligned} & \text { Masood denies } \\ & \text { ole in attack } \\ & \text { on Pak mission }\end{aligned}$}

Fiva: A:jum Muft

KABUL-The former Chief of the Security Council of Afghanistan Ahmad Shah Masood has categorically refuted the accusation of the Pakistan government that he was involved in the attack on Pak Embassy and had a hand in the hijacking of a school bus from Islamabad.

He was informally talking with the delegation of Ulema and Mashaikh from Pakistan who called on him at Estalef Guest House, forty kilometres from Kabul.

Masood said that the Embassy of Pakistan in Kabul was the embassy of a brotherly country who had supported the people of Afghanistan in their fourteen-yearjehad. He could not even imagine such a nefarious act against that country, he added. He said that when the Embassy was attacked the Minister for Foreign Affairs of Pakistan and Military Incharge came to Kabul and said that an important wireless set had been stolen from the Embassy but when he along with the Pakistan officials inspected the Embassy every thing was found intact. He said that the ambassador said that certain important documents were missing but those too were found lying in the safe then finally they said that a special document was missing from the safe. Pakistani officials thanked him for protecting them and saving their life.

On the second occasion, he said certain people were demonstrating in front of the Embassy against 'Pakistan's backing Taliban in taking over Herat' and police were blocking the demonstrators when a shot was fired by some 'unknown' element resulting in the killing of one person. He said that the death of the demonstrator infuriated the mob who ransacked the Embassy. Masood said that he was blamed that he had sent men to Islamabad to hijack the school bus but my own children were taking refuge in Pakistan, how could I do such a thing.

Earlier, addressing the visiting delegation, the Afghan leader said that conspiracies against Millat-i-Islami are being hatched through the governments in . power in the Muslim countries. "If I have any differences with Pakistan those are only with the government and not the people of Pakistan." He said that he had been labelled as anti-Pakistan which is not true. He said that he had categorically stated to various delegations from Pakistan visiting Afghanistan that the politic of Pahistan government was not in theirown fal our neitler in the favour of Afghanistan and nor Millat-i-Islamia. He said that Afghanistan could not follow any advise or suggestion from Pakistani government
He said that both the countries have common interest and added but certain forces did not want to see the Mlujahideen in Kabul. They even wanted to reinstate the government of Najecb in Afghanistan but failed miserably. he said.

Masood said that after the fall of Soviet Union the other superpower knew that if Pakistan. Iran and Afghanistan formed a bloc they would transform into a super force in the region and all Central Asian states would come under their influence. To prevent the formation of such a bloc rift was created among various Afghan factions whoare fighting with each other, he added.

He said that it was proposed to Taliban that 20 ulema from their side and 20 from govemment side should sit together to resolve the differences but ulema from government side waited for the ulema of the Taliban but they did not turn up. He blamed that Taliban were establishing terms with Mazari and Dostum whereas earlier they were asking us to attack on Mazari and Destum. When we attacked Mazari and he was at the brink of defeat Talibans joined hands with him against our earlier pact stating that Mazari had surrendered before them. He proposed that ulemo from Pakistan, Afghanistan and other friendly Muslim countries should get the authority from Taliban and Rabbani and whatever they would decide would be acceptable to every party. About himself he said that he had no lust for power and announced that he would resign from his office and would not accept any office in future as well. $\mathrm{He}$ said that sacrifices of the Muslims of Afghanistan and other countries should not go waste in any case.

Sayyef addressed the delegation in Arabic and stated that Afghan people had great respect and regard for Pukistan as that country as 'Dal-ul-Hijrai" for them. He said that the Jihad was supported by twociltegories of supporters one which toxh it as theit ohligation and others who hid a vesied interest associated with Jihad. Now the vested interests are afraid of Mujahideen observed Sayyef. He said that it was decided at the Malta Conference that the country should not go in the hands of Mujahideen and after the conference not only the support was withdrawn out they started blaming Mujahideen. He said that as Mujahideen entered Kabul America became annoyed and some advised that dialogues should be held with the American authorities but since America is an enemy like the Russians no question of dialogues with it arises. If America, observed Sayyef, ever started a war with Afghans. it would be defeated like Russia. He said that Mujahideen should be prepared for war with America since all their difficulties were engineered by her negative role in the lerritory. He said that in a NATO meeting it was agreed that afier the fall of the communist Russia the only poten- tial danger to west was Islam and $\$ 1.3$ billion was earmarked to combat Islam in the African continent only.

in the fiscuevof fultitun: the Afghan leader said that liwe have no juscification for war with the central government. Sayyef said that a Muslim should not fight with a Muslim but if such a fight was imposed on us we would oo fight in self defienci. Ho said that Tadiban did not understand that encrieat would net er like wo sec anyone in pow or who wanted to inuplement Islanmic Shat iat in the country and Taliban wittilced to en. tablish Isl:amic sy stem of governmemt in Afghanistan. therefore could not afford losee them in power. Sayyef announced that he wanted no war with Talibiat and authorised the visiting (tlemas firom P'it histan to contact them and press them for meaningfiul dialogiles. Salyyef satid that those whoweresteating anisgin in:s between Alghanistan and P'athivan were in fact the enemies of both the countries. On a question that Taliban had certain objections against the centre ruling government that they could not keep peace in the kerritory : ontrolled by them, that they did not recover arms from the civilians and failed to enforce Islamic Shariat in the country. Saryef said that in Kabul daricus ellonic groups were living and poverty. hunger and misery had increased crime rate and if any law was enforced the result would be bloodshed. The atrms possessed by the civilians were the weapotis which they had snatched from the opponents and possession of sach arms were their right under the injunctions of lstum but if Ulemacould tell a religious w ily oul wo the problem then the arms could be withdrawn. e oplatimed Saly gel. Ile said

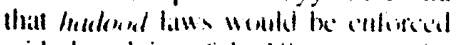
with the askice of the I lemat s/ks the things were setlled and peiac 1 a stored. 


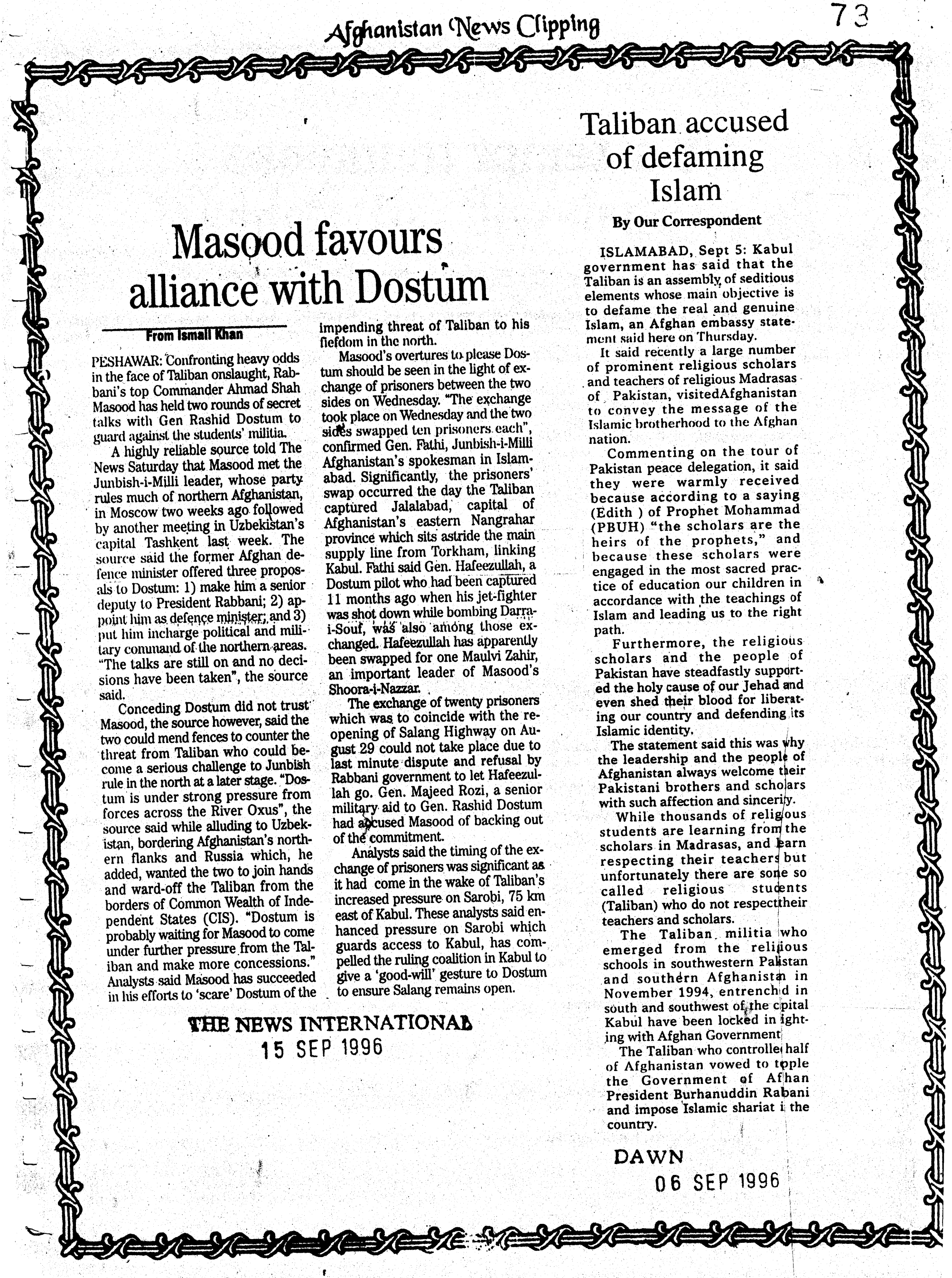




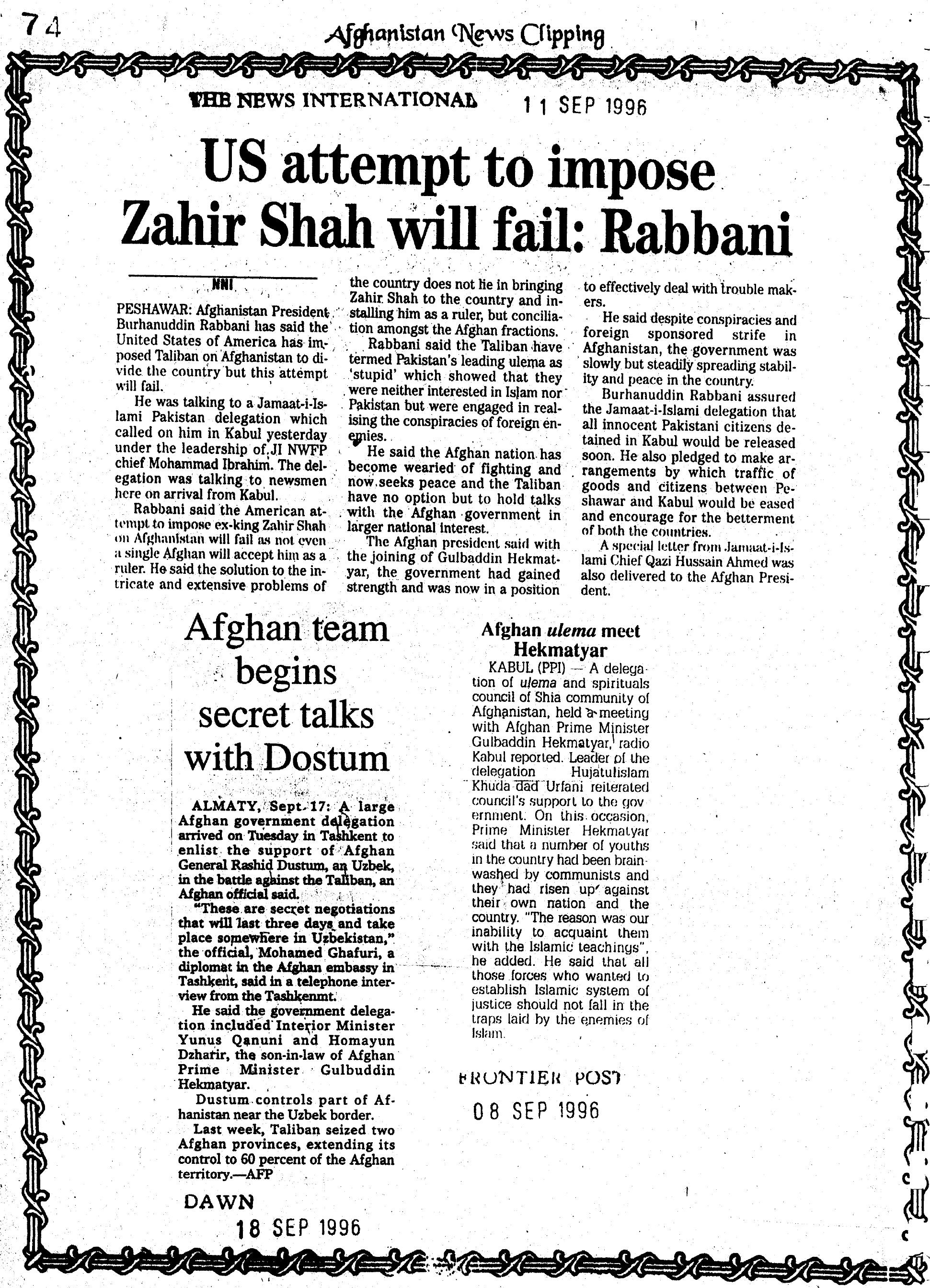




\title{
Kabul claims 43 Pakistanis' arrest
}

\author{
Denies fall of Kunar province to Taliban
}

\begin{abstract}
Agencies
KABUL: The Afghan government on Saturday denied that the Kunar province had fallen to the Taliban, saying that 43 Pakistani infiltrators and 17 Taliban soldiers had been arrested in the area.

"Kunar is still in the hands of forces loyal to the Kabul government," an official spokesman said, following a report by Associated Press, which said that the Taliban had taken control of the province.

The spokesman said that in a failed attack on Friday, 17 Taliban were captured in Kunar, and separately 43 'unarmed Pakistani civilians', who infiltrated into Kunar via
\end{abstract}

the Neva pass across the border, had also been taken into custody. The Pakistanis would be brought to Kabul, he added.

Earlier, the Associated Press said Kunar fell after its pro-government leader surrendered to the advancing Taliban. The Afghan Islamic Press (AIP), a Pakistan-based private information service, said Kunar had not yet fallen and that negotiations were underway between the Taliban and pro-government commanders in the province.

A spokesman for President Burhanuddin Rabbani's military strongman, Ahmad Shah Masood, renewed condemnation of Pakistan, saying, "Peace will never come to
Afghanistan as long as Pakistan interferes in our internal affairs."

Amrullah accused Pakistan of wanting to sabotage every Afghan initiative for peace, and specifically charged that the Taliban's dramatic capture of Nangrahar on Wednesday was with Pakistan's military support.

While the Kabul authorities concede the fall of the neighbouring provincial capital Mehtarlam in Laghman to the Taliban, they claim that the rest of the province is still under their control. "The Laghman district centres of Ali Shing and Ali Nigar are still with us," said Amrullah. Both of these centres guard

Continued on Page

\section{THE NEWS INTERNATIONAL 15 SEP 1996}

\section{Kabul claims 43 Pakistanis' arrest}

\section{Continued from Paye}

entrances to valleys north of Mehtarlam, with Ali Shing particlilarly important as it contruls aic.

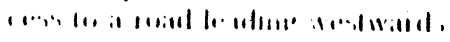

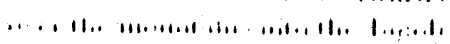

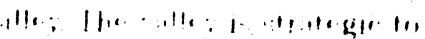
the defence of two ital Kabul government-controlled positions which it links together - Sarobi district centre and Bagram airbase.

Apparently, the Taliban have

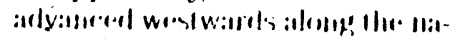

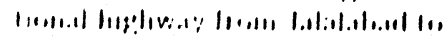

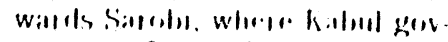
ernment forces have taken up defensive positions. It is not clear exactly where the government front-lines are but they are be. lieved to be about $30 \mathrm{~km}$ east of Sarobi at the far end of Tangi Abresham or the Silk Gorge. "We are confident of our ability to defend Sarobi and Bagram." said Amrullah.
Both jet bombers and military helicopters were observed flying missions from Bagrain airbase on Saturday, according to passengers arriving there on the civilian cart-

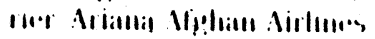

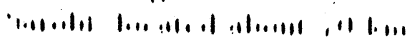

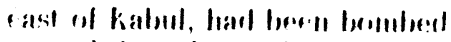
several times by unidentified jets which, Amrullah claimed, had been flying from Pakistan bases. "The jets definitely came from Pakistan," he said.

Pakistan has denied Kabul's al-

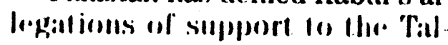

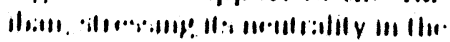
Alghaun lacturinal renillic.t.

Sarobi is defencled by the forces of Ahmad Shah Masood and Prime Minister Gulbaddin Hekınatyar's Hezb-i-Islami faction commander Zardad, who, Amrullah asserts, will halt the Taliban advance. "In Sarobi, we are well established...there will be a bloody war there," he added.

Meanwhile, a senior UN official
Marrack Goulding, who is seeking peace in Afghanistan, toll newsmen in Kabul that a number of foreign countries were involved in the confliet, allhough he declined

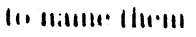

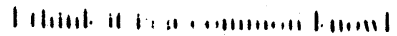
relge llat a mumbles of enumtries are playing a part in tinc conflict," he said when asked about Kabul's charge that Pakistan was helping the Taliban.

He said that the matter had been discussed with the Pakistan

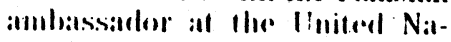

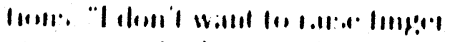
ill ally particular meniloer stalle, though I can confirm that a number of states are involved," he added.

Meanwhile, AIP said on Saturday that the Taliban hald declined an Iranian invitation to attend a planned regional conference in Tehran to discuss ways to end the conflict because the Kabul govermment would be there. 
ISLAMABAD (AFP) - - The former rulers of Afghanistan have Taliban militia "at all costs," an aide to ousted prime minister Gulbuddin Hekmatyar said.

Haii Mohammad Farid said he had spoiken to Hekmatyar by ra-" dio "somewhere" in north" Afghanistan, where the ousted leaders are now believed to be af: ter fleeing Kabul shortly before its capture by the Islamic militia on Friday.

"Hekmatyar told me we have decided to resist and defend Afghan land at all costs," said Farid from the northwestern Pakistani city of Peshawar.

"Our government will remain. we are determined to stay in Afghanistan... Taliban will now face a tough time," he quoted the Hezb-i-Islami chief as saying.

Farid declined to say where exactly in the north Hekmatyar. deposed President Burahunddin Rabbani and his chief military commander Ahmad Shah Masuod had set up their base.

The Hekmatyar aide claimed Bamiyan province in central Afghanistan, inhabited predominantly by Afghanistan's pro-Iran Shiste community, would support the resistance against the Taliban.

He quoted Hekmatyar as inanking Pakistan for hosting "us or 14 vears" during the mujahedeen jehad or holy war against the former Soviet Union which sent troops to Afghanistan between 1979 and 1989 to prop up a communist government in kabul which ultimately fell in 1992.

Gliairat Baheer, a son-in-law of Hekunatyar, said the Hezb-i-Islami leader was "sale and fine", adding that he would determine his future course in a "collective" strategy with Rabbani and Masood.
Baheer, who was designated as Kabul's now ambassador to Pakistan before the fall of Kabul, said Hekmatyar had spoken to him by satellite telephone.

Ruports from Kabul soid the three key figures in the former Kabul administration were at an unknown place - in northorn Afghanistan, where Masood still controls the provinces of Bockakhshan, Takhar and Kuudluz.

Earlier sources in Peshawar said there had initially been indications Hekmatyar might come to Peshawar, but apparently the situation changed late Priday.

The families of Hekınatyar, Rabbani and other Afghan loaders have lived in the past in Peshawar, a former mujahedeen resistance base during the Soviet ocupation of Afghanistan.

One of the two wives of Hekmatyar currently lives in Poshawar and so does the family of Abujul Rasul Sayyaf, chiel of the Afhan Ittihad-i-kslami laction which was part of the ousted coalition.

On Thursday, the Pakistan Foreign Office said the Afghan leaders could come and live in Pakistan.

Afghan sources did not dis. count the possibility of Hekmatyar and Rabbani finally taking refuge in Iran, which has expressed its serious concern over the dramatic course of events since the Taliban started their triumphant march in east Afylianistan earlier this month.

"l'he situation in Afghimistan has turned into a complicziterl and unsolvable issue in the region, and we will, for years to come witness the homelessness and misery of the people thore," Iranian President Ali Akbar Raglsanjani said Friday.

But, Pakistan, which says it is

\section{FRONTIER POST}

sending an official delegation to Kabul, has said the l'aliban takeover "has now created a qual. itatively new situation, "viewing with obvious satisfaction the prevailing calm in Kabul and announcement of a general aunnesty by Taliban supremo Mulla Umar Akhund.

In Teheran, Jranian newspapers voiced displeasure on Saturday over the fall of the Atghan capital to the Islamic Taliban militia, charging that the United States had facilitated the takeover.

Most of the newspapers alleged that in addition to the United States, the Taliban was also actively backed by Pakistan and Saudi Arabia.

The militia's capture of Kabul on Priday was "designed by Washington, financed by Riyadh and logistically supported by Islamaboxd," said Jomhuri Islami, a daily close to Islamic hardliners.

It predicted that the ultra-conservative Sunni Muslim Taliban would be "incapable of running Alghanistan and will be used to pave the way for another group to take over."

"All signs indicate that this will not be the last government in Kabul and the next group may not even have to find itself (in power) through military force, but political dealings," the paper added.

The English-language Tehran Times urged the Taliban to start a dialogue with other Afghan factions "to prevent further blood. shod."

"Taliban's objective has always been to create a new brand of an Islamic government. It has now the opportunity to prove its sincere intentions and create an atmosphere of peace," it said.

"With their violent methods. the Taliban can neither run the country nor gain the support of their people or foreign powers," said the moderate daily Himshiohri. "The hanging of Najibullah has drawn the rage of the international community." 


\section{Kabul govt invites Taliban for talks on interim set-up}

\section{From Our Correspondent}

PESHAWAR - The Kabul regime has accepted the Taliban proposal with regard to the formation of an interim government in Afghanistan and has invited the latter to come to a negotiations table.

This was claimed by a 50-member ulema delegation which returned to Peshawar after holding meetings with Afghan President Rabbani, Prime Minister Gulbadin Hekmatyar and Commander Ahmad Shah Masud in Kabul.

The peace mission headed by Maulana Abdur Rahman told journalists that the Afghan President has offered an olive branch to Taliban, saying that they should choose any process of election during the era of Khulefa-e-Rashedin on the basis of which an Islamic government could established.

The delegation informed the Kabul government about the three proposals of Taliban for starting negotiations with Kabul regime. In return, Gulbadin Hekmatyar presented five proposals to Taliban to establish a true Islamic government in the country. The peace mission will meet Taliban next week to apprise them of the Kabul administration's proposals.

Maulana Abdur Rahman said that both the Afghan President and the Prime Minister expressed willingness to sacrifice their office, if needed, for the formation of an Islamic government in Afghanistan.

He said that the main purpose of the delegation's visit was reconciliation among warring Muslims according to teaching of Quran, adding that they will also include ulema from Pakistan and from Saudi Aabia in the future delegation for stepping up the peace process there.

The proposals of Taliban include announcement of Islamic system, disarmament of important cities including Kabul and the removal of dishonest persons who are occupying key offices in the Kabul government.

In response Prime Minister Gulbadin Hekmatyar accepted the formation of interim government and presented five proposals for restoration of peace. Those are: Forthwith declaration of ceasefire, formation of interim government through negotiations. disamement of unconcerned persons and formulation of electoral system in the petren of Khulefa-e-Rashadin on permanent basis.

He called upon Pakistan and other Muslim countries to play their duc role for restoration of peace in Afghanistan.

The head of the delegation informed newsmen that at present they were trying to strike reconciliation between Taliban and Kabul government and there was no such proposal to involve Rashid Dostum in the process under way.
Taliban's negative response to peace condemned

ISLAMABAD (PPI) - The Afghan government has condemned Taliban for not giving positive response to the peace efforts by Pakistani ulema and mashaikh who recently visited Kabul and wanted to visit Kandahar.

"These so-called Taliban are an assembly of seditious elements whose main objective is to defame the real and genuine Islam", said a statement issued by Afghan embassy in Islamabad on Thursday.

The statement said "thousands of. religious students, who are learning from scholars in madrassas respect their teachers, unluckily, there are some so-called religious students (Taliban) who do not comply with their Islamic duties and avoid respecting their teachers and scholars.'

\section{FRONTIER POST}

\section{SEP 1996}

\section{- condemned for not giving response to peace efforts}

ISLAMABAD (PPI) - The Afghan government has condemned opposition Taliban for not civing positive response to the peace efforts by Pakistani Ulema and Mashaikh who recent ly visited Kabul and wanted to visit Kandahar

"These so called Taliban is an assembly of seditious elements whose main objective is to defame the Islam", said a statement issued by Alghan embassy in Islamabad Thursday.

The statement said, "thou sands of religious students, who are learning from scholars in madrassas respect their teachers, unluckily, there are some socalled religious students (Taliban) who do not comply with their Islamic duties and avoid respect ing their teachers and scholars".

The statement said recently a large number of prominent religious scholars and teachers of re ligious madrassas of Pakistan. in cluding Maulana Rahat Gul, Maulana Fazalur Rahman Qureshi, Maulana Abdur Rahman Ashrafi and others paid a visit to Afghanistan to convey the mes sage of the Islamic brotherhood good will and yood neighibourli. ness of the Muslim and brotherly people of Pakistan to the Afghan nation.

The distinguished scholars were accorded a sincere and warm welcome by the leadership and the people of the Islamic state of Afghanistan.

As the religious scholars and the people of Pakistan have steadfastly supported the holy cause of our Jehad. This is why the leadership and the people of Afghanistan always welcome their Pakistani brothers with such affection and sincerity, the statement added. 
05 SEP 1996

\section{Afghan team due for talks on food items import}

ISLAMABAD (PPI) - A fourmember Afghan food purchase delegation is likely to arrive here in a couple of days for talks with Pakistani officials on import of food items from Pakistan. Afghan sources said on Saturday.

"The delegation, headed by deputy minister for commerce Abdur Rehman Saleehi, will be in Islamabad on Sunday or Monday on a week-long visit to Pakistan", sources said.

Pakistan foreign ministery has informed Afghan embassy in Islamabad that Pakistan consulate in Jalalabad has been given instructions to complete visa formalities of the members of delegation. who have already reached the capital of Nangrahar province.

The delegation will hold meetings with Pakistani officials in the ministries of finance, commerce. and states and frontier region (SAFRON) for the purchase of food commodities from local market.

An Afghan ministerial delegation, headed by interior minister Younas Qanooni, visited Pakistan in the second week of August and showed desire to purchase essential food items from Pakistan. Islamabad had decided, as a goodwill gesture, to meet the immediate requirements of the population of Kabul through the local market. Pakistan side had expressed readiness to facilitate transportation through its land of the items, the Afghan government decides to import from outside world.

\section{FRONTIER POS?}

O 1 SEP 1996

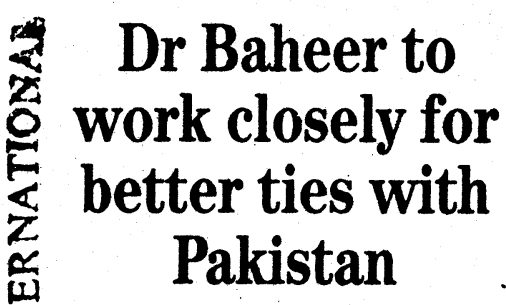

ISLAMABAD: Afghan Ambassadordesignate to Pakistan $\mathrm{Dr}$ Ghairat $\mathrm{Ba}$ heer has said it will be his first prior-

$C$ ity to play role for strengthening

brotherly relations between IV Afghanistan and Pakistan.

"I consider Pakistan as my second a. home because I have stayed with Pak-

as istani brethren for alooit 16 years and

* will channelise my energies to work for the betterment of the people of both the brotherly Muslim countries," Dr Ghairat said in an interview here Wednesday.

Meanwhile, the Afghan Embassy in Islamabad confirmed nomination of Hizb-e-Islami's Dr Ghairat Baheer as new Afghan Ambassador to Pak. istan. A high official in the embassy said the proposal of Dr Ghairat has already been forwarded to the Pakistan's foreign ministry and formal approval by the Government of Pakistan is awaited.

Dr Ghairat expressed the hope that forthcoming visit of Pakistan Secretary foreign affairs Najmuddin Sheikh to Kabul will prove as another step in cementing relations between the two countries.

He was recently nominated as special envoy of the Afghan prime minis. ter to Pakistan. -PPI

\section{Afghan govt's trade delegation arrives}

From Our Correspondent

PESHAWAR - A three-member delegation of Afghan government for purchasing medicines and other items of daily use, arrived in Peshawar on Tuesday.

The delegation included Abdul Rehman Saleh, Deputy Trade Minister, Wasal Noor Deputy Chief of the Presidential Secretariat and an officer from finance department in the light of a recent understanding between Islamabad and Kabul. The items to be purchased by the Kabul delegation included medicines, food stuff and other items.

It may be mentioned here that $\mathrm{Ka}$ bul's official delegation is touring Peshawar for the first time in the last three years.
Afghan govt blames Pakistan for Jalalabad fall

ISLAMABAD (AFP) - A spokesman for Prime Minister Gulbuddin Hekmatyar in Kabul accused Pakistan Thursday of providing troops for the latest Taliban offensive on Jalalabad.

The spokesman, Hamed, said the militia fighters had been allowed to enter Afghanistan from Pakistan.

He also said Pakistan troops had taken part in the new offensive in the eastern province of Nangarhar

"After the Taliban themselves failed, Sham Shad military base was captured in a second offensive by Pakistani troops," the spokesman claimed. Sham Shad is around seven kilometers from the Pakistan border.

The Pakistan Foreign Office on Thursday again denied giving aid to the Taliban.

"Pakistan has rejected the allegation and the fact that there was very little fighting in Jalalabad should convince them that Pakistan was not involved," a Foreign Office spokesman told reporters.

Experts in Kabul said it appeared there had been a halt to the normalisation between Afghanistan and Pakistan. But the Pakistan spokesman said there had been no "setback."

He said a visit to Kabul next week by top foreign ministry official Najmuddin Shaikh was "still on."

The main Afghan-Pakistan border crossing at Torkham, around 70 . kilometers from Jalalabad, was also closed Wednesday, as Islamabad decided to review developments.

But the spokesman said the crossing was closed because "there was much talk of people crossing into Afghanistan."

Relations between the two had only just started getting back to normal after a mob burned down the Pakistan embassy in Kabul last year.

"The events have hit the task of our mission which came with a long shopping list to Peshawar," said an official of the Hezb-i-Islami faction.

"Jalalabad is important for us," said Hezb's Ghairat Baheer. Afghanistan's ambassador-designate to Pakistan.

But an Afghan expert in Islamabad, who requested anonymity, said: "The Hezb-iIslami's militiary presence in this region where ethnic Pushtuns dominate appears to be fading out." He added that there was "a lot of sympathy and support for the Taliban in

\section{$\Rightarrow$} (1) 
KABUL (AFP) - A US diplomatic mission has held talks in Kabul with military strongman Ahmad Shah Masood and Afghan Prime Minister Gulbuddin Hekmatyar, an American diplomat said Sunday.

-We are interested in the general Afghan peace process.' said John Holtzman. deputy US ambassador to Islamabad, describing the mission's trip here as a 'routine visit.'

After meeting Hekmatyar Sunday morning Holtzman said he would next fly to the southern provincial capital Kandahar to hold talks with the leaders of the Taliban Islamic militia which is currently beseiging Kabul.

Aides to Masood, who hosted a dinner for Holtzman Saturday, said one item discussed with the Americans was the sensitive issue of the proposed arms embargo against Afghanistan.

Imposition of an arms embargo will not be fair. It will only victimise the government,' said a spokesman for Masood.
The spokesman pointed out that whereas the Kabul government had to rely on easily monitored air transport to receive arms, opposition factions could use the largely unpoliceable 'porous Pakistani border'.

An Afghan arms embargo would only mean the strengthening of the Taliban, he added.

Accompanied by Brad Hanson of the US Consulate in Peshawar, Holizman flew into Kabul Saturday on a Red Cross flight from the northern provincial capital Muzar-i-Sharif.

In Mazar, Holtzman said he met with ex-commmunist General Abdul Rashid Dostam, who recently agreed with Kabul to re-open the Salang Highway linking the two centres after nearly three years closure due to factional fighting.

While there is a glimmer of hope for a negotiated peace with Dostam's National Islamic Movement of northem Afghanistan, clashes continue south and east of Kabul between pro-Kabul

\section{Afghan team arrives to buy food, fuel}

ISLAMABAD, Sept 8: An Afghan Kabul via the neutrally adminisgovernment team has arrived in Pakistan seeking to buy food and fuel in an apparent warming of once-strained ties between the two sides, a Pakistan-based private Afghan news service reported on Sunday.

The team plans to buy 4,000 tonnes of wheat flour, 3,000 tonnes of cooking oil, 2,000 tonnes of sugar, 1,000 tonnes of rice and 300,000 tonnes of diesel oil, the Afghan Islamic Press (AIP) quoted team leader Wasil Noor as saying in an interview.

Noor, a deputy director in President Burhanuddin Rabbani's office in Kabul, said in Peshawar on Saturday that his team would hold formal talks with Pakistani officials in Islamabad.

He said the embattled Afghan government wanted to transport food and fuel bought in Pakistan to

DAWN

\section{factions and the Taliban}

From their bases in adjacent Logar province, the Taliban are poised to enter Ningarhar province, the shoora or ruling council of which has mustered a defence force now dug-in alongside a joint group of fighters from both Masood and Hekmatyar.

According to Kabul military officials the Taliban have concentrated their forces in two Logar locations in preparation for an attack.

It appears the Tuliban pose a dual threat: east to the Ningarhar capital Jalalabad and north to the district centre of Sarobi, located about 75 kilometres east of Kabul.

Fighting is yet to start in Ningarhar province, and the situation in Jalalabad is calm according to travellers' reports. To the southwest of Kabul no fighting was reported Sunday and the national highway to the Taliban provincial centre Maidan Shahr was open to civilian traffic after closure on Saturday.

Kabul ready

\section{to welcome Pakistan \\ delegation}

ISI.AMABAD, Sept 17: The Afghan government of President Burhanuddin Rabbani has informed Pakistan that it will welcome a Pakistani mission due to arrive in Kabul on Thursday, the Afghan Islamic Press (AIP) said here Tuesday.

The visit was agreed to in normalisation talks held by an Aighan ministerial delegation in Islamabad last month.

Pakistani delegation's visit looked uncertain after Kabul regime last week had accused Islam. abad of helping the robel Taleban Islamic militia in the ir capturing of two more provinces in castern part of the war-1orn $A$ fghanistan.

P.akistan's Foreign secretary Najmuddin Sheikh wat undertaking the visit "to clant the air" which was fouled by the murning of l'akistant embassy a youtr ugo after the satme charge libit islam. abad was helping the militia. of fo

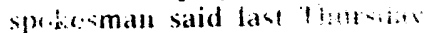
lin's

DAWN 18 SEP 1996 
Kabul asks
Islamabad
to 'recall'
Taliban

KABUL, Sept 16: The Afghan government accused Pakistan on Monday of being behind the Taliban onslaught and urged Islamabad to "recall its militias".

"The Afghan government calls upon the parliament, people and Islamic parties in Pakistan to press...certain (Pakistani) circles to call back Pakistan's militias from Afghanistan," Aziz Murad, President Burhanuddin Rabbani's spokesman, said.

Pakistan denies that it supports the Taliban, which captured Jalalabad on Wednesday in its latest drive to topple Rabbani.

Afghan government officials claim that Taliban could not have captured Jalalabad and border areas without Pakistan's support.

"Peace will never return as long as Pakistan continues interfering in the internal affairs of Afghanistan," Rabbani's top military commander Ahmad Shah Masood said last week.

He was speaking to Marrack Goulding, UN under-secretary for political affairs, who was visiting Kabul to explore prospects for a UN-brokered peace settlement.

Rancour over the Taliban has soured relations between Pakistan and the Afghan government, although these had improved before the latest Taliban gains in eastern provinces.

Pakistan's secretary foreign affairs, Najmuddin Sheikh, is due to go to Kabul on Thursday to reopen a diplomatic mission in temreopen a diplomatice to replace the embassy that was ransacked and burned by a mob of protesters a year ago.

But the latest broadside from Rabbani's spokesman casts doubt on whether Sheikh's visit will go ahead.

"A pre-condition for reopening the mission was that the Kabul govthe mission was that hostile propaganda against us," said a foreign office source in Islamabad. "We will decide on Wednesday whether the secretary's visit will take place or not."

In Jalalabad, where a governIn Jaid killed 12 people and ment air raid killed 50 on Sunday, the ruling Taliban shura (council) decided to keep up military operations against the government, the Peshawarbased Afghan Islamic Press agency reported.

It said the Taliban planned to use Jalalabad airport to launch air and missile attacks on government military targets.-Reuter

\section{Dr Baheer appointed Afghan envoy to Pakistan}

\section{By Mariana Badbar}

ISLAMABAD: Afghan government Tuesday announced the appointment of Prime Minister Gulbadeen Hekmatyar's son-in-law Dr Ghairet Baheer as envoy to Pakistan as Foreign Office meets today to decide the fate of Foreign Secretary Najmuddin Sheikh's visit to Kabul.

Baheer, who is already stationed in Islamabad as Hekmatyar's Special Envoy, told The News, "I was delighted to be informed by the Foreign Office in Islamabad that they had accepted my nomination. Pakistan government has been very kind in my case, which was processed in two weeks. It has also been indicated to me that as a special case I will be presenting my credentials to President Faroog Leghari very soon."

Though Dr Baheer says that he would take charge of the Afghan Embassy very soon, he still cannot be received by senior officials at the Foreign Office until he presents his credentials. Normally the protocol at the Foreign Office is that a few ambassadors call on the president together instead of being received individually. But keeping in view the Afghan situation, and renewed efforts to improve relations with Kabul, Dr Baheer may be allowed to present his papers to either the chief of protocol

Some elements

\section{damaging ties}

with Islamabad: Kabul Afghan government Monday accused elements in Pakistan of interfering in Afghanistan following the dramatic advances of the Taliban Islamic militia in eastern provinces. a meeting here that "some elements" in Pakistan, including the interior minister, were trying to disrupt relations between Islamabad and Kabul.

The council asked Pakistan's Islamic parties, parliament, politicians and the people to block the involvement of the "selfish elements" in the internal affairs of Afghanistan, said Abdul Aziz Murad, a spokesman for President Burhanuddin Rabbani. or the foreign secretary. But the chief of protocol is abroad with the president and also Dr Baheer's case has not reached his office.

But this has not stopped Dr Baheer from commenting on Afghan situation which has changed dramatically since his nomination. About Dostam's decision to throw his weight behind Kabul, Dr Baheer said, "Dostam is a wise man who has made the right decision at the right time".

Meanwhile, a meeting takes place at the Foreign Office today (Wednesday) in which Foreign Secretary Najmuddin will finally decide whether his Kabul trip is on or not. An official at the Foreign Office said, "it is still not decided, though security is no problem. We'll see if things are in order. It has not been cancelled." Besides the foreign secretary, DG of Afghan Desk, Arif Ayub and his Director Naeem Khan are also to visit Kabul.

There would be little for Islamabad and Kabul to talk about at a time when President Rabbani is fighting for his survival. "Sheikh's visit would also send wrong signals to the Taliban whom the govt cannot ignore in future. All Rabbani will do is complain to our Foreign Secretary. When we have even closed down our Consulate in Jalalabad how can we be talking about reopening our Embassy in Kabul?" asked a political observer.
KABUL (AFP) - The embattled

The State High Council said at

"We believe that there are some circles within Pakistan, including Interior Minister Naseerullah Babar, who do interfere in the home affairs of Afghanistan," Murad claimed.

Babar, a retired general, has been accused of backing the Taliban militia; a charge he denies.

Murad alleged that Pakistan dispatched arms and ammunition to the Taliban in Nangarhar.

He also claimed that an officer of Pakistan's military intelligence service awarded a medal for heroism and 500,000 dollars cash to Mulla Borjan, a top Taliban commander who led the advance into the garrison city of Jalalabad.

FRONTIER POST 17 SEP 1996 


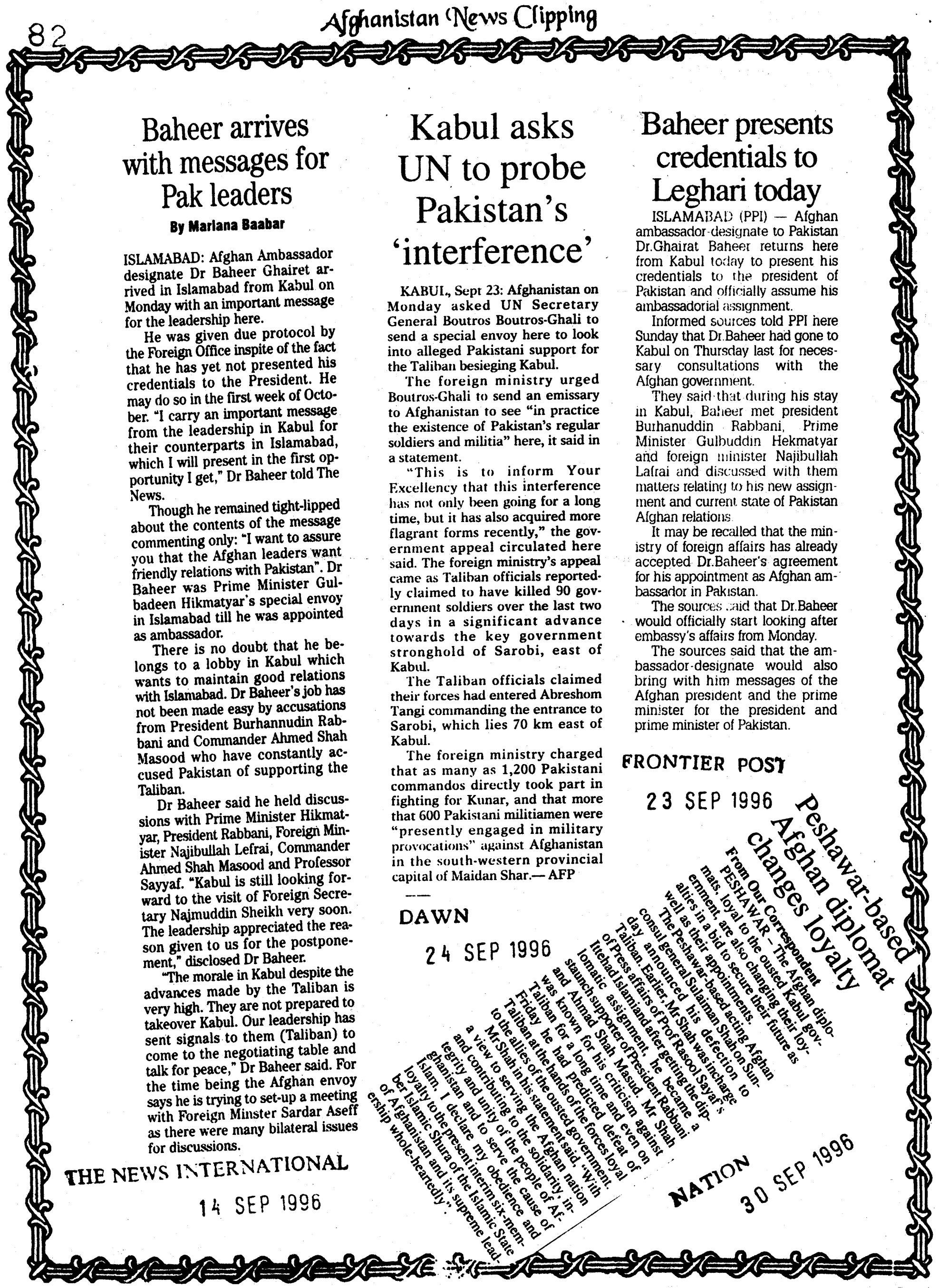




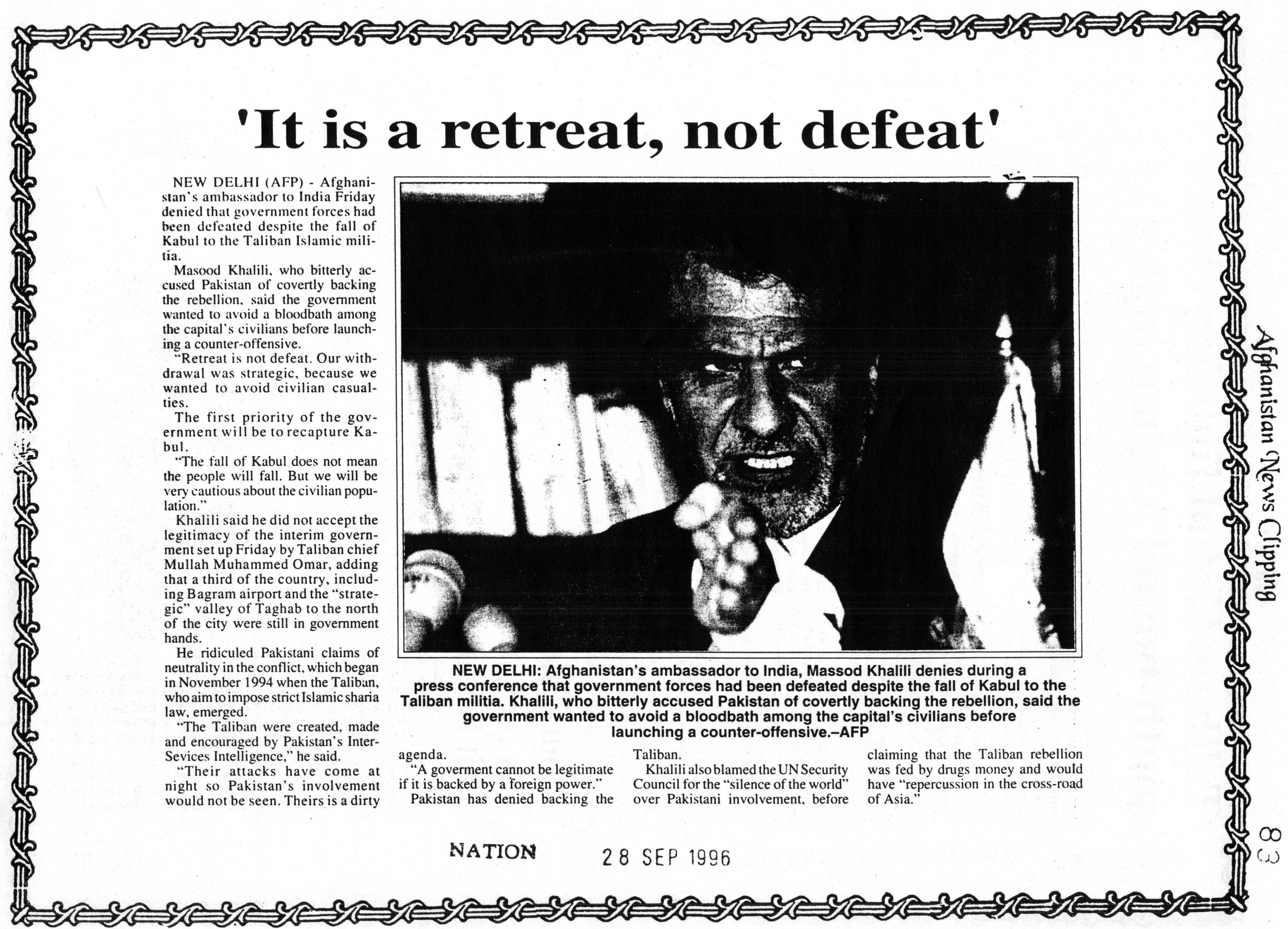




\section{Taliban-Kabul fighting closes south-bound Afghan highway}

KABUL (AFP) - Afghanistan's southwestern-bound national highway was closed Monday as fighting broke out between Kabul government forces and the Taliban militia, leaving one soldier dead and seven civilians wounded, Western sources said.

"The highway was closed to all traffic from early this morning," a Western aid agency worker told AFP.

He said pro-Kabul troops stopped all traffic heading from the capital on the road toward the Taliban-controlled provincial centre of Maidan Shahr, but it was unclear which side. if any, had launched an attack.

Maidan Shahr is located about 35 kilometres (21 miles) from Kabul, with the Talib ... frontlines some 5 kilometres (about three miles) before the provincial centre.

From Maidan Shahr the highway heads southwest to the Taliban headquarters of Kandahar. from where there vere unconfirmed reports of troop movements in the direction of Kabul.

Defence Ministry spokesmen were not alailable to explain the inorning's military activities.

A south Kabul hospital reporled seven civilian casualties with shrap-

\section{Four killed as rockets hit Kabul}

KABUL, Sept 2: Rockets crashed into Kabul on Monday, killing at least four civilians, as Afghan gov. errument forces launched a twopronged offensive on Islamic Taliban rebels south and southwest of the city, witnesses said.

Government troops unleashed a deafening early morning rocket harrage against laaliban positions in the Arghandi area, about $20 \mathrm{~km}$ southwest of Kabul, before launch ing a ground of fensive towards the strategic town of Maidan Shahr.

Taliban sources in Peshawar confirmed there had been heary fight ing on frontlines around Aighandi, but said the government side had been unable to advance.

The Pakistan-based Afghan Islamic Press (AlP, agencs said both sides had iuffered castiajtics, with the Tatihoun losing at least mo fighters. Another six Talilian sar rors were wounded. nel wounds caused by rockets fired in the morning by the Taliban.

Soldiers on the main Darulaman road in south Kabul stopped journalists at a site where two $122 \mathrm{~mm}$ long-

\section{Iranian team} continues talks

KABUL (AFP) - A Iranian delegation Monday continued talks with faction leaders here as it reiterated Tehran's offer to hold a regional conference on the war in Afghanistan.

The leader of the delegation. Murtaza Sarmadi, Iran's deputy foreign minister for cultural affairs, told a press conference at the Iranian embassy here that he had met with Afghan President Burhanuddin Rabbani and his military strongman A hmad Shah Masood, since arriving last Saturday.

He had also held talks with Rabbani's former rival Gulbuddin Hekmatyar, who became Prime Minister in June this yeur, he said.

Sarmadi said he would next travel to the central Afghan capital of Bamian to meet with Karim Khalili, leader of the opposition Hezh-iWahdat faction. range rockets had expleded. tom up the asphalt and killed one soldier. The soldiers wanted the dead hody carried away for burial.

Other uniformed troops of pro-Kabul factions seen headling for the Darulantan Palacce in suilh Kabul wold AFP lhey had been ondered an their fontline positions.

"They (Talibam) won' hate any victory." the soldiers declared.

"We can defeat them. They are the agents of Pakistan."

The govermment accuses Pakistan of supporting the Talihan militia. which has besieged Kabul lor nine months in a bid wo lopple Presidemt Burhanuddin Rabbani.

Pakistan denies hacking the Taliban, saying it maintains neutrality in the Afghan warr. The soldiers said pro-government trosps were on alert at two south Kabul laciations. in addition to Maidan shallr.

There were lots of tron) movements reported in the capilal Sunday night and very carly Monday morning government jels from Bagram airbase, 50 kilometres north of Kabul, were reported on bombing missions agains the Taliban in the south.

No lurther details were immedi alcly available.

Witnesses said both sicles used - Hekmatyar and Abdurrab Rasul heavy artillery during several Sayyaf, leader of the Ittehad-i. hours of fighting. which closed the Islami faction, had all taken part in Maidan Shalir road.

the government assault on the

Although the Taliban control Taliban.

Maidan Shahr, they have allowed Differences between Masood and the highway I" remain open as the former opposition leader Hekmatmain route for Kabul's supplies of yar, who rejoined the Kabul govfirewood, cooking oil, flour, fuel ernment in June, had previously and livestock.

Government troops also attacked inhilbited joint military operations.

The Taliban, entrenched in posiTaliban positions south of the capi- tions to the south and southwest of tal, beyond the Darulaman Palace Kabul for the past year, have sworn area, provoking rebel gumers to to oust Rabbani and impose strict target residential areas in south. Islamic rule throughou dfghanis. west Kabul.

Sources at the Karte Seh hospital said at least four civilians had been killed and 15 wounded in the exchanges.

The AIP said fighters loyal to President Burhanuddin Rabbani's top commander Ahmad Shah Mas tim.-Reuter

THE NEWS INTERNATIONAL DAWN 03 SEP 1996 ood, Prime Minister Gulbuddin 
ARGHANDEH (AFP) - The tional highway was open to civilian traffic Tuesday after being closed for one day because of factional fighting, witnesses said.

"There has been little shelling today and traffic started from early morning moving in both directions," a security guard at the Kabul government frontlines in Arghandeh village told AFP.

In Monday's fighting the staterun Bakhtar news agency reported eight civilians killed in Kabul and another 18 wounded by incoming rockets fired by the Taliban militia.

Pro-Kabul factions are dug-in on multiple frontlines some 25 kilometres (15 miles) southwest of Kabul at Arghandeh village, facing their Taliban militia rivals across a three kilometre heavily mined no-man's land.

A few salvoes of $122 \mathrm{~mm}$ longrange rockets. were seen fired in the direction of the Taliban's base in the provincial capital of Maidan Shahr about 10 kilometres (six miles) distant from Kabul government frontlines.

But according to a government tank commander, Monday's fighting was not on this highway but further southeast, on hilltops of the Taliban-controlled Lalandar valley.

"We captured six Taliban posts that were on high ground dominating our positions," tank commander Abdul Salam said.

Lalandar is a strategically important valley for both sides as it links Maidan Shahr with south Kabul, albeit through inhospitable mountains:

The degree of calm on the frontlines could be judged by the fact that, in addition to the movement civilian traffic, Abdul Salam and his men were perched atop their tank smoking hashish for "relaxation."

Defence Ministry officials were not available to comment on frontline fighters' statements that it was troops loyal to Afghan President Burhanuddin Rabbani and not the Taliban who initiated Monday's fighting.

Rabbani's military strongman, Ahmad Shah Masood, was reported on the frontlines directing fighting Monday, together with General Fahim, head of the national security department.

\section{Two killed in rocket attack on Kabul}

KABUL: Rockets killed two civilians in Kabul on Sunday as an Iranian envoy visited the city to invite Afghan Foreign Minister Najibullah Lafrai to a peace conference in Tehran, governmentcontrolled radio reported.

It said the rockets, fired by the Taliban milit.. entrenched in hills south of the Afghan capital, also wounded 14 people and destroyed six houses.

The Iranian envoy, Murtaza Sarmadi, invited Lafrai to a conference of regional foreign ministers to be held in Tehran in October to promote peace in Afghanistan, the radio said.

Iran is inviting the foreign ministers of all Afghanistan's other neighbours - Pakistan, Tajikistan, Turkmenistan and Uzbekistan - to the meeting, but not rival Afghan factional leaders.

A Russian delegation led by Ivgini Mikhailov, a special envoy of President Boris Yeltsin for Tajik affairs, held talks with Prime Minister Gulbadin Hikmatyar about security on the Afghan-Tajik border, the radio said.

Moscow says Islamic Tajik rebels fighting the Russianbacked government in Dushanbe use bases inside northern Afghanistan. Hikmatyar, quoted by the radio, told Mikhailov that the solution to the Tajik conflict lay inside Tajikistan.

He added that his government would encourage the Tajik opposition to hold talks with the Tajik government to pave the way for elections. - Reuter

TRE HEW'S IVIERYATONAL

02 SEP 1996
Kabul claims seizing Taliban posts

KABUL, Sept 4: Atghan government forces captured eight Taliban posts in two days of clashes south of Kabul, the defence ministry said.

The conflict eased after fighting between pro-Kabul factions and the Taliban on Monday and Tuesday, defence ministry spokesman Ghaffar Rashidi said.

He told journalists eight Taliban posts and an unspecified number of prisoners had been captured. A military official said two rocket launchers and ammunition dumps were also been destroyed.

Residents said rockets were fired into south Kabul on Tuesday night and Wednesday injuring seven civilians.

Government officials routinely blame the Taliban for rocket attacks.

In Pakistan a Taliban spokes. man, Amir Khan Muttaqi, denied the government allegations over the rocket attacks. He said the government was behind the attacks in a bid to defame the Taliban movement.

The Taliban has been besieging Kabul for more than nine months vowing to topple President Burhanuddin Rabbani and enforce Islamic law.-AFP

\section{Kabul govt claims military gains against Taliban}

KABUL: The government soldiers on Tuesday claimed to have captured eight posts from rival Taliban troops, southwest of the Afghan capital.

The fighting began Monday forcing the closure of a key road to Maidan Shahr, about 45 kilometers southwest of the city. The road opened late Tuesday morning but several truck drivers, who made the journey to Maidan Shahr and back, said the road was littered with burned out tanks and there were giant gouges in the middle of the road from government bombs. - Agencies

THE NEWS INTER:YATIONAL 04 SEP 1996 


\section{ERONTIER POS? " 06 SEP 1996 \\ Taliban move infantry, tanks towards Sarobi}

KABUL (AFP) - A large strike force of the Taliban religious movement Thursday headed north towards Sarobi on the main national highway linking Kabul with the Pakistan border, military sources said.

"An estimated 300-400 Taliban backed up by 10 tanks was on the move today, " a military officer loyal to Afghan President Burhanuddin Rabbani told AFP.

He said the aim of the Taliban strike force was "to cut the Kabul. Jalalabad highway and threaten Tagob Valley" if possible.

There was no immediate con firmation of the Defence Ministry claims.
Sarobi is a district centre 75 kilometres (46 miles) west of Kabul on the main road to the eastern provincial capital Jalalabad, which is close to the Pakistan border.

Although Jalalabad is under the control of a shoora or council which has declared neutrality, the Kabul government has been attempting to woo them on side with offers of military assistance.

Sarobi, which is defended by fighters from Prime Minister Gulbuddin Hekmatyar's Hezb-iIslami faction, controls access to the Tagob Valley, which is strategically important as it opens out onto the plains 50 kilometres north of Kabul where the government's vital Bagram airbase is lo"cated.

Although some skirmishes between the Taliban attacking force and pro Kabul factions have already been reported the religious militia still have a long way to travel before they reach Sarobi.

It is unclear yet which route the Taliban may select for their reported march on Sarobi.

From their bases in southeast Kabul there is a good motorable road through the Lataband Pass to Sarobi but this is heavily guarded by troops loyal to Rabbani's topgun Ahmad Shah Masood.

\section{Taliban, Kabul troops brace for final showdown}

KABUL (DPA) - The Afghan government and the Taliban militia seem to be preparing for a batthe in Sarobi area some 65 kilometers east of Kabul, the Afghan Islamic Press (AIP) agency said Thursday.

AIP said Taliban sent 1,500 more troops to Jalalabad, capital of Ningarhar province which it captured last week, and the Kabul government had reinforced its defenses at Sarobi to block the Taliban's intended advance on the national capital. Thousands of citizens of Jalalabad have fled the city fearing in outbreak of fighting.

AIP agencies and the United Nations Special Mission in Afghanistan (UNSMA) located in the city had started evacuating their expatriate staff after last week's government air raids against the city.

AIP said Taliban attack on Sarobi will be multi-directional and will be supported by the militia airforce. President Rabbani and Hekmatyar have asked pro-Kabul commanders in northern provinces to send their forces to Kabul.

\section{ERONTIER POST}

20 SEP 1996

$$
08 \text { SEP } 1996
$$




\section{Govt forces repulse Taliban attack}

KABUL (AFP) - Afghan government forces have repulsed an overnight armour-backed infantry assault on western Kabul by the Islamic Taliban militia besieging the city, an official statement said Wednesday.

"The attack started at 8:45 p.m. (local time) (1615 GMT) and continued until 1:00 a.m. (2030 GMT) last night," the statement issued by President Burhanuddin Rabbani's faction said.

This was the first Taliban attack against Kabul since the capture of two key provincial capitals .- Jalalabad in eastern Nangarhar province and Mehtarlam in nearby Laghman -. by the religious militia a week ago.

Some 400 Taliban infantry backed up by 12 tanks and armoured vehicles attacked the Afghan capital from their western frontline positions, about 25 kilometres (15 miles) from Kabul, the statement said.

The Taliban attack was backed up by an artillery barrage on government positions in the south and southeast of the capital, which has been encircled by the faction for the past 11 months, it said.

There were however no territorial gains by either side in the battle near the southwest highway linking Kabul with the southwest of the embattled country, the communique added.

THE NEWS INTERNATIONAL FRONTIFR IOST 19 SEP 1996
The statement issued by the office of Rabbani's military strongman Ahmad Shah Massood, repeated a direct accusation that Pakistan is aiding the Taliban in their attacks against the beleaguered government.

"The Pakistani-backed Taliban militia launched one of their strongest assaults against government positions around Kabul," the opening line of the statement said.

The Kabul government claimed to have inflicted "heavy casualties and damages" on the Taliban, while suffering "few casualties" to its own forces.

Meanwhile, to the east of Kabul government jets were Wednesday carrying out further bombing raids on the Nangarhar provincial district centre of Hisarak, which was captured by the Taliban a week ago and where the government are attempting to hem in the militiamen and halt their advance.

In another related development, reports here said a planned meeting between a Kabul delegation and northern Afghan warlord, General Abdul Rashid Dostam got underway Tuesday in the Uzbek capital Tashkent

Dostam has so far stayed out of the Kabul-Taliban conflict, preferring to style himself as "democratic, moderate and a peace-maker" diplomatic sources in Kabul said.

\section{Hekmatyar fighters reach Sarobi}

\section{By Ahmad Hassan}

PESHAWAR, Sept 19: About 1500 fighters of Afghan prime minister Hekmatyar's Hezb-i-Islami on Thursday arrivedin Sarobi to defend Kabul against an expected onslaught by Taliban militia.

The contingent, under the command of commander Abdus Samad, arrived from Mazar-i-Sharif, the sources here said.

The Taliban forces supported by heavy artillery and tanks are positioned about 30 kilometres from Sarobì and ready for a final battle for the control of the last government defence line 70 kilometres south of capital Kabul.

An earlier report had indicated that northern warlord Rashid Dostum has agreed to support the Kabul regime in defending itself against Taliban's impending attack for capturing of Kabul but the report was denied later by a Dostum's aide Gen Yusuf.

Meanwhile, another report which was confirmed by local Hezb sources, said that the government forces had launched an offensive against Taliban forces in Laghman province.Taliban sources, however, claimed to have repulsed the said attack.

Laghman province's capital Mehtar Alam, it may be mentioned was captured by Taliban last week without any resistance although its strategic places like Alinigar and Alishang in north and north west were still in the control of official forces loyal to Hekmatyar's Hezb-iIslami.

\section{DAWN}




\section{inforcements sent abul frontlines}

fighting Friday government troops regained Ali Sheng and captured the adjacent district of Daulat Shah.

Hamed said the reinforcements were not fighters from excommunist General Abdul Rashid Dostam's. National Islamic Movement. although they werf: from northern areas under Desstamis centrol.

The reinforcements have been sent by the Jehadi Ceruncil of the irerth. headed by Hezb i Islami commander Juma Khan Hamdar. Hamed saich

Althrough Hekmatyar and Archan President Burhanuddin Rabbani have been trying to woo Dostam on side in their fight aigainst the Taliban. the northern Uzbek leader has so far remained neutral.

However Western observers say Drtsam is showing covert support by allowing convoys of indicenous Hezb i Islami rein. forcements to pass from his territory to Kabul

Hekmatyais's

envoy. Humayun Jareer. told reporters in Katbul that talks between the northern leader and the govern ment were continuing, and the main topic on the agenda was getting Dostam to join the gov. ernment.

"After the main agreement is reached issues like (Dostam's own) troop support may be raised," said Jareer.

Jareer and Interior Minister Yunus Qanooni will leave soon for talks at the Bamian province headquarters of another SSC component. Hezb-i. Wahdat lead er Karim Khalili

Khalili, like Dostam, has so far resisted Kabul government attempts to persuade him to come on side against the Taliban who control all the territory further west in central Ghor province.

Western observors doubt Dostam will declare support for the government unless Kabul faces the threat of imminent capture by the Taliban.

By the expedient dispatch of SCC fighters in the name of Hezb-i-Islami from his northern territories. Dostam has cleverly allowed needed reinforcements to reach Kabul without jeopardising his official impartiality, analysts here said.

\section{Kabul admits Taliban's advance}

KABUL, Sep 24: The Kabul government on Tuesday admitted that the Taliban had advanced towards its key eastern stronghold of Sarobi, saying the militia had captured the entrance to the strategic Silk Gorge nearby.

"Taliban claim of capturing the whole gorge are false, but it is true that they have arrived at the entrance" of the gorge east of Sarobi, a military source told AFP.

Tangi Abreshom, or the Silk Gorge, which stretches for about 25 kilometres from Sarobi, is guarded by government troops loyal to by governme Minister Gulbuddin Hekmatyar and President Burhanuddin Rabbani.
Nearby Sarobi is believed by military analysts to be the Islamic fighters' next target following a series of victories in the area over the past two weeks. Its capture by the paliban would seriously the Taliban would seriously
increase the military pressure on the beleaguer ment, they said.

Sarobi is crucial not only as a symbol of resistance, but also because it controls access to the only operational airport in government hands, at Bagram 50 kilometres north of Kabul, they said.

Government forces had been attempting to move eastwards from the gorge towards the crucial town of Jalalabad.-AFP
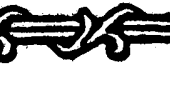


\section{Taliban put up pressure around Sarobi}

Kabul charges Pakistan with backing students militia

\begin{abstract}
From Rahimullah Yusufzai
JALALABAD: Buoyed up by their recent string of military victories in eastern Afghanistan, the Taliban broke through Rabbani government frontlines Monday to capture the strategic Wrekhmin Tangi gorge near Sarobi on the Jalalabad-Kabul highway.

During a visit near the frontlines Monday, this correspondent talked to a number of Taliban fighters and common people returning from Wrekhmin Tangi area with the news that government troops were pushed back in a Taliban counter-attack Sunday evening Earlier Kabut regime had claimed its troops overran Taliban positions to rurkakn positions to reach near Surkhakan, from where a road leads into Laghman's provincial capital, Mehterlam.

This scribe neither saw any government presence nor fighting in or near Surkhakan. Local shopkeepers said government warplanes had bombed the area a day earlier without causing any damage to Taliban
\end{abstract}

military targets. The frontline was ahead on Jalalabad-Kabul road and most accounts tended to support the Taliban claim that they had advanced from their earlier positions at Spina Thana to capture Sarkandow Kandao and Mashali Kandao before reaching the Wrekhmin the Wrekhmin Tangi gorge.

An Afghan demining engineer, requesting anonymity, told The News that the Taliban had neared the Pule Istehkam and would soon be able to threaten Sarobi town, sited 15 kilometres ahead, because there were no natural defence beyond Wrekhmin Tangi.

He said about 14 government sol diers lost their lives in Sunday' fighting, including eight whose bodies lay beside the road. He added that the Taliban captured four government tanks and one more of its tank and a military vehicle were damaged when blown-up by landmines. Incidentally, the mines were planted by government troops themselves in a bid to keep the Taliban at Continued on Page

THE NEWS INTERNATIONAI 24 SEP 1996

\section{Taliban put up pressure}

\section{Continued from Page}

bay. One Taliban fighter was killed and a few wounded in the fighting

Haji Mir Mohammad, a Taliban commander who along with Maulvi Abdul Razzaq led the assault, earlier said the Taliban were capable of tak ing not only Sarobi but also Kabul.

"The likelihood of bloodshed of civilians in case of a Taliban attack on Kabul has restrained us from launching a full scale assault on the Afghan capital," he argued. He said eight government troops hailing from Kunduz district earlier surrendered to Taliban along with their arms and were later allowed to proceed to Pakstan.

Despite their military gains in the Wrekhmin Tangi frontlines, the Tal iban didn't appear pushed to launch a decisive attack to capture Sarobi. In fact, they appeared more concerned about consolidating their positions in their recently captured Nangarhar Laghman and Kunar provinces.

There were sketchy reports of some resistance by government troops in Alishang valley of Laghman but otherwise it seemed the Taliban were firmly in control in Nangarhar and Kunar.

Meanwhile, the government warplanes continued to indiscriminately bomb areas recently lost to Taliban. Resident of Jalalabad and Mehterlam. terrorised by bombings which have killed mostly civilians, complained that Kabul regime instead of conronting Taliban in the frontlines sending its jet-fighters to bomb civitian areas. A number of peole left the two cities for people have escape the cilies for safer places to

On the other hand, the Kabul regime Monday wrote to the UN secretary general to appeal to him to stop Pakistan from interfering in Afghanistan's affairs. The letter leged that Pakistani troops fighting on the Taliban side in were and Maidan Shahr areas. had in the past denied all had in the past denied all such allegations. Independent sources too haven't yet confirmed any Pakistani involvement in the Afghan powerstruggle.

AFP adds: Taliban Monday advanced toward the key government stronghold of Sarobi after killing around 90 rival troops in two days of fighting, Taliban officials said.

A Taliban spokesman, quoted by the Afghan Islamic Press (AIP), claimed that the militia had entered Abreshom Tangi (Silk gorge), commanding the entrance to Sarobi, a government bastion 70 kilometers east of Kabul.

The militia was in control of the mountainous gateway to Sarobi after "fierce fighting," Amir Khan Muttaqi told the private information service rom Kandahar in southwest Afghanistan 


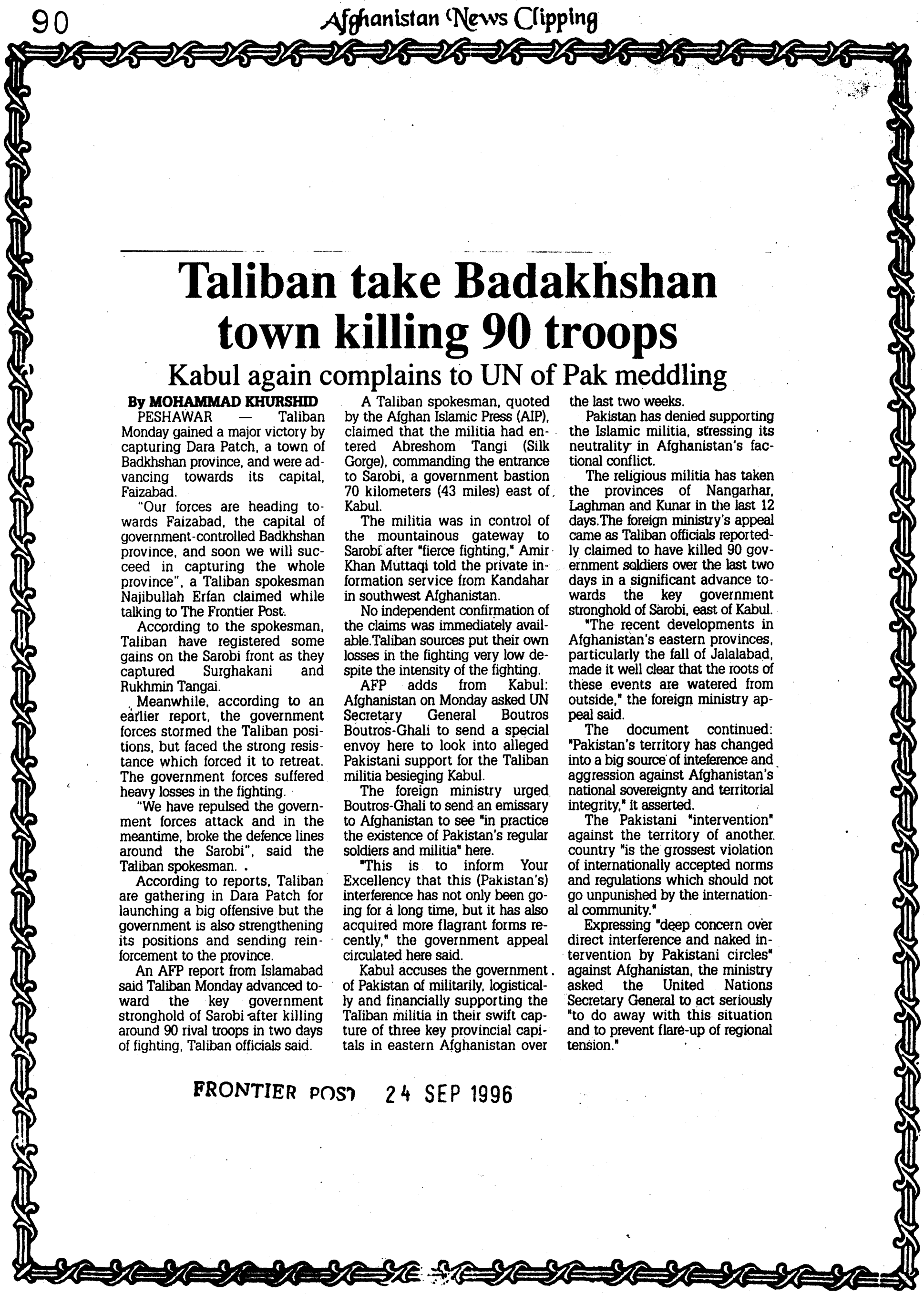


with the Taliban. He assured Kabulis There were also conflicting re ayyaf. Repor safer places fuge with his kmatyar's people. Hekmatyar

Iranian Deput abul would ary solutio change its policy towards them. He pointed out that Iran had tried to im ho refute is of Islamabad's interference in ghan affairs. He said there was no ing the Taliban. urned down the to seek nredical treatment. Dostum is the Kabul regime.
Earlier Sarobi fell to the Taliban at pm Tuesday when th matic battle Ananistan. Opce Sarol plies power to Kabul other column headed for Tagao in Kapisa province. From Tagao it 


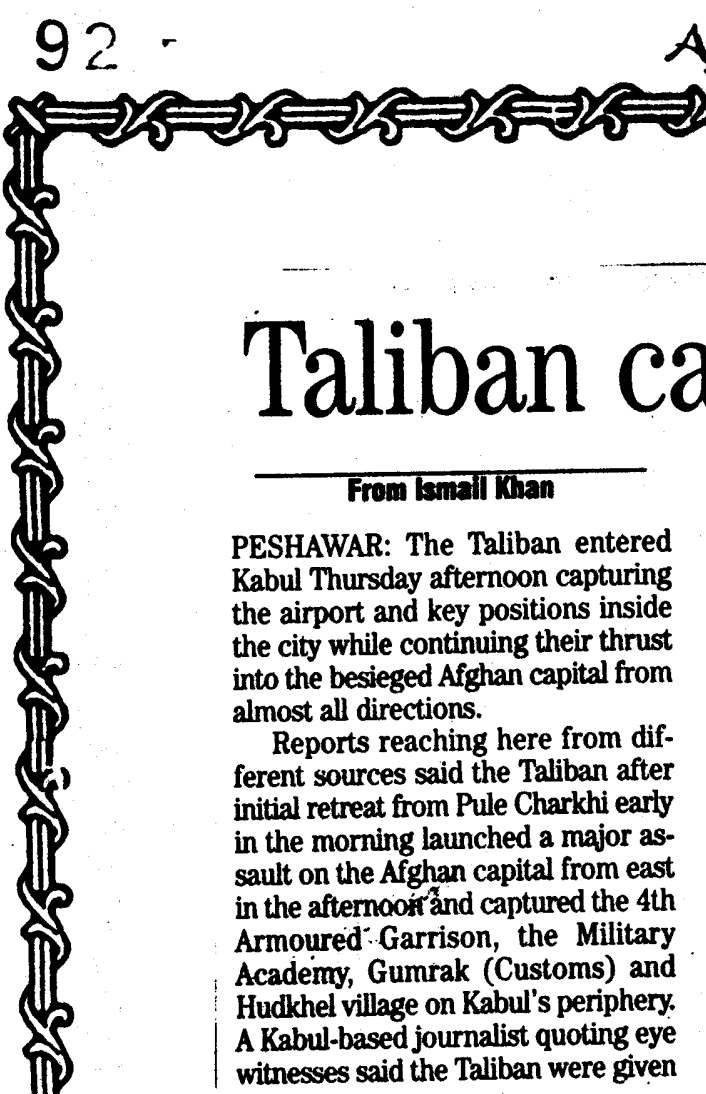

\section{Taliban capture Kabul airport}

a warm welcome by the war-weary
people living in the city outskirts.

The students militia, undeterred by the death of their top commander Mullah Borjan, further made their way to the Soviet-built Macroryan residential complex. Latest reports said fighting was continuing as retreating government troops tried to stall the advancing Taliban.

Taliban said their forces captured the Khwaja Rawash airport and knocked out Radio Kabul out of service. The $\mathrm{BBC}$ correspondent in Kabul said gunshots could be heard in the posh Wazir Akbar area. Another report said the government troops seem to be abandoning their checkposts in the city and heading north. It said the retreating soldiers have abandoned Security Ministry, leaving behind six tanks and several vehicles. "The city looks like a ghosttown," the report added.

The Taliban also captured the Bagram airbase towards the north and warned planes against flying into the Kabul's main air-link from $\mathbf{1 5 0 0}$ hours Thursday (Kabul time). The Taliban said they have cut off the Kabul-Bagram Road and are closing in on Kart-l-Seh. Latest report said the Taliban have also captured vital positions on the strategic Tapa Maranjan in the south of the

Continued on Page
Continued from Page 1

city. Eye witnesses in Jalalabad said further Taliban re-enforcement was on the way to Kabul.

There is no word about the whereabouts of President Rabbani, Commander Masood, Prime Minister Hikmatyar and Ittehad-i-Islami leader Abdur Rab Rasul Sayyaf. Unconfirmed reports said Hilkmatyar was holed up in Istalif between Kabul and Bagram.

His son-in-law and Afghanistan's newly-appointed Ambassador to Pakistan Dr Ghairat Baheer said the -Prime Minister's satellite phone was quiet since morning and nothing could be known about his fate.

Meanwhile, a communique issued from Kabul said Hikmatyar would fight the battle till the very last end.

"The Taliban should not take Kabul for granted," he warned. "Taliban and their sponsors should know that they would not find a single soul who would sell his conscious, the nation and country for the sake of a few pennies, "he said.

However, Dostum's Junbush-iMilli supported the UN Security Council's call for a cease-fire and called for a negotiated settlement. Describing the fighting as meaning- less, a communique issued from Mazar-i-Sharif said, it would only further complicate matters and lead to more bloodshed.

Un the other hand, the ICLC' and UN have called off their operation to evacuate international relief agencies' officials. The head of the ICRC Mission in Islamabad, Oliver Durr, said he had been advised by his Kabul mission to suspend the operation till further notice. "We've been advised by our colleagues in Kabul not to enter into Bagram till further notice," he told The News. Security officials said the UN and ICRC evacuated 18 foreign citizens from Kabul to Peshawar.

Int an other development, the Amnesty International in a fax message to The News from London, "urgently" called on the Taliban leadership to abide by the war rules and immediately stop indiscriminate attacks on the city.

"Time and again the warring factions have shown a complete disregard for the lives of the civilians and it appears that the people of Kabul are now in danger of an imminent bloodbath," the AI said while calling on the international community to "act now and prevent possible bloodshed in the Afghan capital."

THE NEWS INTERNATIONAL

FRONTIFD nOST 27 SEP 1996
DAWN

DAWN 
KABUL (AFP) - Residents of the embattled Afghan capital Kabul heaved a collective sigh of relief Tuesday as the electric supply was partially restored after years of blackout.

About one-third of Kabul had electricity restored after power transmission cables were connected to a main hydro electric dam at Sarobi east of the city, officials said Tuesday.

But the restoration may be shortlived as Sarobi is the next strategic target of the Taliban Islamic militía, which was been sweeping through provinces to the east of the capital.

The Taliban, who have vowed to topple President Burhanuddin Rabbani, captured two provincial capitals in eastern Afghanistan last week and were close to Sarobi, which guards the mouth of the gorge leading to Kabul's only operating airport at Bagram.

Residents in Kabul's diplomatic enclave Wazir Akbar Khan and the northwestern suburb of Khair Khana had a pleasant surprise Monday when they suddenly found their lights on. The power supply to Kabul had been cut in January 1994 following an abortive coup mounted against President Burhanuddin Rabbani by northern warlord General Abdul Rashid Dostam and a former opposition faction, the Hezbi-i-Islami of Gulbuddin Hekmatyar.

Hekmatyar this year signed a peace deal with his former foe Rabbani and became Prime Minister in June, enabling the government to have access to the power plants located in the Hezb stronghold of Sarobi.

Until power was restored, Kabul was believed to be the only national capital without electricity.

Kabul's power transmission cables have now been connected to Naghloo hydro-electric dam, one of the main power-generating plants in Sarobi district, 70 kilometres east of the capital, officials said.

Another powerstation at Mahiper in the same area also briefly. supplied some electricity to parts of the wartorn Afghan capital in March this year. But it did not last long because the water level was too low to run the turbines.

Officials said the government imported the cable from India and extended it alongr 30 kilometres of mountainous terrain to the Naghloo dam.

The resumption of electric power - if it remains constant - can be a big help to the impoverished citizens of Kabul, who remain solely reliant on expensive imported fuel and firewood.

Although one-third of the city had been lit, residents of the remaining sections cannot expect electricity any time soon as the power system had been looted in the past four years of factional fighting.

"Currently, only 30 per cent of the city has been given electricity, the transmission cables for the rest of it have been destroyed," the official Bakhtar news agency said.

A planeload of power cables to be used for internal repairs arrived in Kabul on Monday, while more were scheduled to be airlifted to Kabul from Iran in the future, Bakhtar said.

\section{'Save Children' brings joy to battle-weary children of Kabul}

KABUL (AFP) - On a calm, sunny morning in battle-scarred Kabul Thursday the aid agency Save the Children inaugurated a playground for Afghan youngsters, many of whom have grown up knowing only the horror of war.

"This is our second playground. Eventually we wilt supply each of Kabul's twelve districts with something similar," Afghan project manager Zaid Osmayi told AFP.

In this government housing estate known as Microrayan, the US based aid organisation, which set up shop in Kabul in May 1995 . has built a complete playground with swings and slides, as well as courts for volleyball and basketball, and even a permanent table for chess.

"A community committee has been organised to look' after these facilities, and store items like the basketballs and nets," Osmayi noted.

Throngs of obviously thrilled children, not to mention young adults, jostled each other for a turn in this new 2,000-dollar playground.

Looking around this neighbourhood once a front line in the battle between pro-Kabul troops and an opposing Afghan faction. apartment blocks pitted with machine gun bullets and massive holes caused by incoming artillary rounds are still a common sight.

"We are so happy that this battle ground has now been turned into something like a schoolground," exclaimed a joyful parent.

Bits of shrapnel could still be found lying in the dust, a grim reminder that since April 1992 when the mujahedeen defeated the Afghan communists in Kabul. factional fighting has never stopped here. 


\section{Afghanistan News Clipping}

KABUL (AFP) - The people of Kabul reacted with polarised joy or fear Friday to the dra: matic overthrow of the Afghan government by the Taliban Islamic militia.

Some local Pushtuns see the arrival of their ethnic brothers as deliverance from the previously Tajik-dominated rule of President Burhanuddin Rabbani and his military strongman Ahmad Shah Masood.

"We dealt with Masood and his gang the same way we did with Bacha Saqqao," boasted one Pushtun trader, referring to the ethnic Tajik ruler overthrown nearly 70 years ago by the Pushtun king, Nadir Khan.

Still others, including more cosmopolitan Pushtuns, see the religious fundamentalism of the Taliban as a threat to the secular lifestyle they have enjoyed in the country's capital city.

"We are leaving for Central Asia. Perhaps Europe if we have enough money," a former academic said.

He was against the Taliban's prohibition on girls going to school, the closure of cinemas and their ban on television, and the fact that women, if allowed out of the house, should be fully covered up.

Others, even racially sensitive Tajiks, have adopted a "wait-and-see" attitude.

But there is one facet of the Taliban presence that all Afghans look on favourably there is no crime problem in areas under their control.

"The Taliban are against stealing and robbery," a student stated.

People who in recent months crossed the frontlines west of Kabul often remarked at the. stark differences between the Taliban's behaviour and the behaviour of some pro-government factions. The Taliban were honest. they said, while the pro-government factions often robbed them.

The Taliban are not a well known quantity, however, having emerged on the Afghan scene from religious schools a mere two years ago. There is much speculation about what and who they truly represent.

Since they appeared in the southern capital Kandahar in late 1994, they have rapidly taken much of the country, buoyed by their firm belief that they herald the beginning of a much needed Afghan religious renaissance.

"The Kabul government weren't unbelievers but they were corrupt," Taliban leaders often say.

Prime Minister Gulbuddin Hekmatyar, Rabbani and his top military commander Masood have fled somewhere into the north of the country - their exact whereabouts were not immediately clear - and can be counted on to attempt to resist the Taliban on their home-ground.

About 100 kilometres (62 miles) north of Kabul is the entrance to the Panjsher Valley,
Masood's home patch and the likely next battleground.

Masood has transferred huge stockpiles of heavy weapons and ammunition to Panjsher over the last several months as a contingency) against his defeat in Kabul.

Masood still controls the three provinces of Badakhshan, Takhar and Kunduz, as well as large tracts of Baghlan province, which cover difficult mountainous terrain well suited to guerrilla warfare.

To the west lies the fiefdom of Masood's other main rival, ex-communist General Abdul Rashid Dostam, whose self-declared neutrality in the current war may soon be put to the test.

"We have no problem with Dostam if he implements true Shariah (Islamic religious law)," a Taliban official told journalists in Kabul.

This is doubtful, as many Taliban from Kandahar have old scores to settle with Dostam from the time the Uzbek warlord's socalled Jawzjan militia was a mainstay of the now deceased Najibullah's communist regime.

Taliban hanged Najibullah in their first public act after entering Kabul Friday.

But there is speculation that this discord could be patched up to prevent the war spreading towards the Central Asian borders, where potential profits from future trade override sectarian differences.

\section{Kabul Wor not meeting}

KABUL (AFP) - Taliban militia enforced their strict Islamic code by beating some women with sticks because they were not considered properly dressed, but some food prices have come down, residents said Sunday.

New food supplies and have also started arriving in the capital, where the main civilian ai:port reopened Sunday so a UN envoy could visit Kabul for talks with leaders of the fundamentalist group in the Afghan capital.

Witnesses said at least three of the women seen being beaten by Taliban on the streets of Kabul were told to return home and to dress correctly in public.

The Taliban overran Kabul last Friday and have put heavy restrictions on women's ac: tivities as part of their campaign to set up an Islamic state.

The Taliban generally seem to want to dis courage women from appearing on the streets, but this is not forbidden in Islam, and Kabul women, although in much less numbers. were seen out in the bazaars on Sunday.

All women must now observe a strict Islamic code of dress, which means that when in public they must wear the full-flowing 'chaderi' which covers face and body. Hours after their entry into Kabul, the
Taliban announced on Radio Kabul that "All sisters who have outside work should stay at home till further notice."

However, a senior Taliban leader Mullah Mohammad Rabbani told journalists that Islam recognises the right of education for women.

But a large per centage of the Kabul workforce, in particular professionals such as administrators, doctors, teachers and nurses, are women who are now hit by the work ban.

If this decree becomes permanent it may well mean a real addition to the economic suffering of war-weary families in Kabul who have no male bread-winners

Ten years of war during Afghanistan's occupation by the former Soviet Union, as well as the past four years of factional fighting. has left a lot of families where mothers are responsible for making sure children are fed.

The average price of essential foods in Kabul dropped 15 per cent, and fuel 35 per cent. Sunday compared to last Thursday before the Afghan capital fell

The Taliban, who took control of Kabul from the forces of President Burhanuddin Rabbani and Prime Minister Gulbuddin Hekmatyar, immediately allowed trucks of foodstuffs to enter the town from three na-

\section{ished for dress code}

tional highways traders reported.

However, in spite of open highways and the drop in prices, the majority of citizens are impoverished after four and a half years of factional fighting and still cannot afford regular food and clothes for themselves.

One 90 kilogram (200 pound) sack of wheat flour, the staple food in Afghanistan, costs 270,000 afghanis (18 dollars), one $5 \mathrm{~kg}$ (11 pound) can of cooking oil costs 68,000 afghanis (4.5 dollars), and one seer $(7 \mathrm{~kg} / 17$ pounds) of rice costs 75,000 afghanis (five dollars).

Civil servants normally earn around seven dollars a month, which does not even 10 per cent of their primary needs.

"I am happy for the drop of the prices and the new developments. But I think my family will still suffer if necessary arrangements are not adopted quickly," said Mohammad Aslam, a transport ministry employee.

Meanwhile, the capture of Kabul by the Taliban has strengthened the local money afghani currency against the US dollar, the Pakistani rupee and other foreign currency.

The rate of the afghani Saturday was 15,500 per dollar and 370 per Pakistan rupee, while it was 19,000 and 450 respectively on Thursday before the fall of Kabul. 


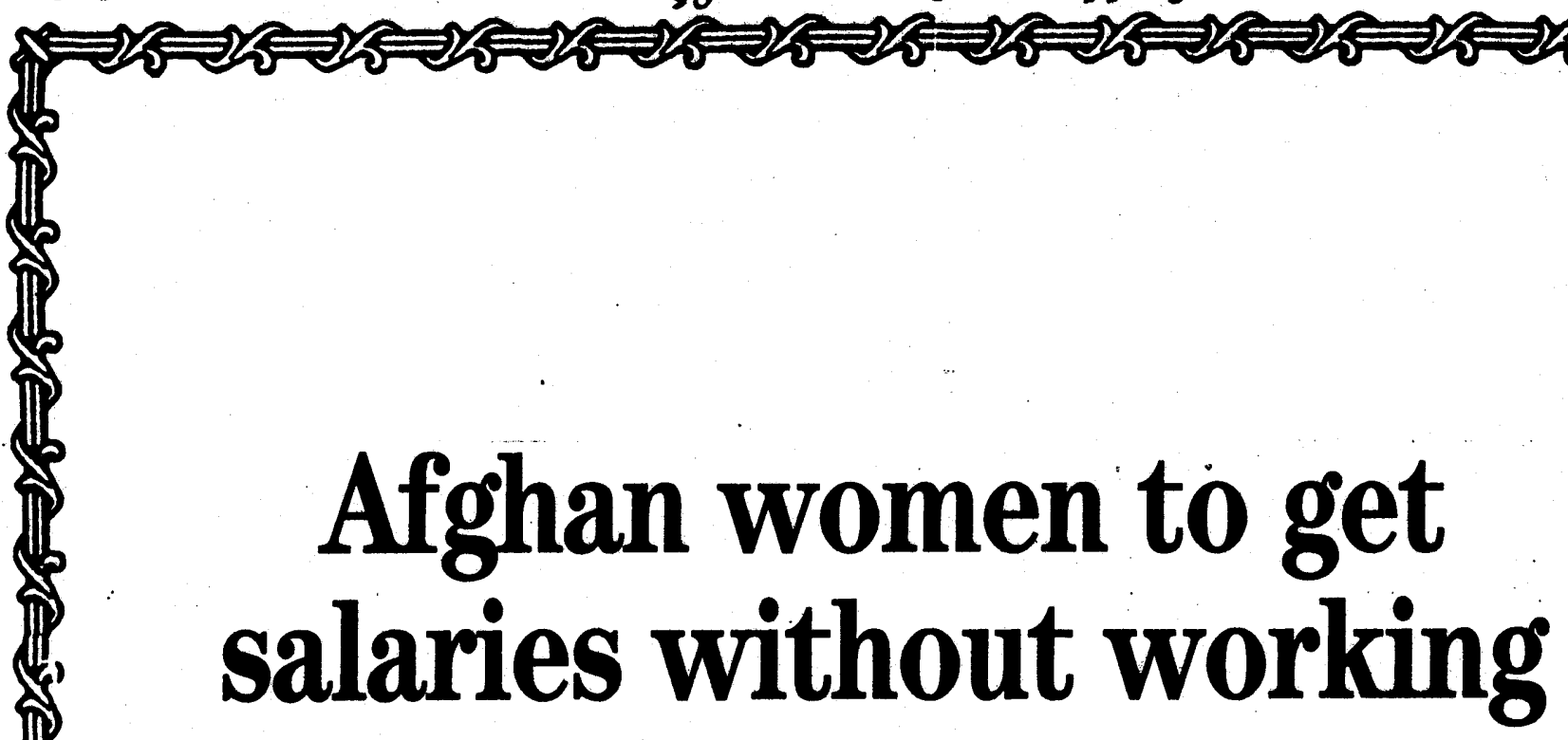

\section{From Rahimullah Yusufzal}

KABUL: Stunned by criticism both at home and abroad for closing the doors of employment on women, the three-day old Taliban administration in Kabul announced Sunday that all laid-off female government employees would be paid salaries without doing any work.

"We would pay the women employees so that they aren't exposed to financial difficulties. But we stand by our decision that women cannot work in government offices in future," announced Maulvi Wakil Ahmad, a member of the Taliban central Shura and secretary to the movement's founder Maulvi Mohammad Umar, in Kandahar in southwestern Afghanistan.

Two days ago, the Taliban had ordered women to stop working in offices in Kabul and announced closure of girls schools pending a decision by religious scholars on the issue of women education. The move was widely criticised, both by human rights activists and also those who worried about the fate of working women widowed during the Afghan war.

Meanwhile, the bodies of former Afghan president Dr Najibullah and his younger brother Ahmadzai, both executed by Taliban in the early hours Friday, were Sunday handed over to one of their uncles residing in Kabul.
The bodies, dishonoured by Taliban while kept hanging in Kabul's Aryana Square for about 26 hours, were reportedly taken to Dr Najib's native Said Karam district in Paktia province in southern Afghanistan for burial.

The Kabul airport, closed more than a year ago due to severe Taliban rocketing and shelling at that time, became operational Sunday when a UN plane carrying Norbert Holl, special envoy for Afghanistan, and his delegation flew to the capital for talks with Taliban leaders. His plane later returned to Islamabad.

The airport manager, Ghulam Mohammad Timar, told The News that the six Ariana Afghan Airlines planes were also being flown to Kabul now that it was safe to fly there and the runway had been repaired. The Taliban have named Maulvi Ismail as its commander for the airport's security.

Beside the reopening of Kabul airport, another sign of normalcy returning to city was the resumption of duties by government employees, the hustle and bustle in the bazars and the reduction in prices of essential commodities due to fighting. The restoration of traffic on four major routes into Kabul - ie Kabul-Jalalabad, Kabul-Maidan-Shahr, Kabul-Charasyab-Logar, and Salang highway, helped bring in supplies to meet the needs of the people and contribute to a drop in prices.
Meanwhile, a Taliban spokesman Maulvi Amir Khan Mutaqqi claimed that Charikar, capital of Parwan province north of Kabul, was now completely under their control. There were conflicting reports about the control of Jebel-us-Siraj, not much far from Charikar. Taliban officials in Peshawar claimed they had captured the town but there was no independent confirmation of the claim. Ahmad Shah Masood, the military strongman of ex-president Rabbani's government, was earlier stated to be reorganising his defeated troops in Jebelus-Siraj to stop the advancing Taliban.

Maulvi Abdul Jalil, a Taliban offcial who looks after Afghanistan's foreign relations, told The News from Kandahar that their leader Maulvi Mohammad Umar had objected to the use of the word "government" for the former rulers. He said Maulvi Umar was a pious and God-fearing man and should be recognised as Amirul Momineen by all Afghans and accepted as such by other countries, especially in Islamic states.

On the other hand, the Afghan consul general in Peshawar Syed Sulaiman Shah Sunday declared his allegiance to the Taliban government. He once belonged to Prof Sayyaf's Ittehad-i-Islami and was subsequently given diplomatic assignments. He was appointed by the Rabbani government to his present post.

THE NEWS INTERNATTONAL.

30 SEP 1996 
 \\ Hundreds of Afghan refugees deported}

\section{Sending back of Jalalabad-fleeing families unprecedented}

\section{From Ismail Khan}

PESHAWAR: In an unprecedented action Wednesday, Pakistan deported hundreds of new refugees from the eastern Afghan capital, Jalalabad.

"We've got to follow the government policy of not allowing fresh refugees, ${ }^{n}$ commented an official of the political administration in the Khyber. The new refugees comprised the fifty-odd families who had literally gate-crashed into the PakAfghan border at Torkham, $6.00 \mathrm{pm}$ Tuesday evening. The Khyber Rifles border-guards had to eventually give in to their pleas and they were allowed in.

However, the refugees were stopped at Michni and Prang Sam check-posts on the main Peshawar(Torkham highway, were put up close to the borders but later moved into the verandahs of the bus stand at Torkham following a heavy downpour and hailstorm. The deportation $\{$ began early Wednesday morning.

An official, who put the number of refugees deported back to
Afghanistan at close to 50 families, said the action was carried out in accordance with the government policy. "We've orders to permit people with valid documents only," he said.

The "valid document" stance does not make sense as Pakistan has at present no diplomatic mission working either in Kabul or Jalalabad. Pakistani diplomatic staff at its consulate in Jalalabad was evacuated after its fall to the Taliban on September 11. There is also no hard and fast rule for distinguishing a fresh refugee from amongst the hordes of people gathered on either side of the Durand Line. As one official put it, "the rule of the thumb is not to allow a person who has bag and baggage."

The action is also surprising since an official hand-out on Tuesday informed that a refugee camp for new refugees from Jalalabad would be set up at the Nasir Bagh refugee camp. A meeting held in this connection was attended by the Commissioner Afghan Refugees, Rustam Shah Mohmand and head of the UNHCR mission in Islamabad, J. Moucht.
UNHCR has agreed to provide tents to the new refugees while a request is to be made to private donor agencies to provide food and other basic assistance. "This is not in our knowledge," a political administration offcial said who was informed that a team of UNHCR visited the border to assess the possibilities of establishing another camp in Nangrahar.

A senior official of the Commissionerate for Afghan Refugees said the decision to establish a refugee camp was taken in view of reports that thousands of people were fleeing Jalalabad due to fears of air- early returmofmore thanamillion Afghan. bombing by Kabul jets. He quoted a refugees living in Pakistan.

UNHCR official saying that approxi- The Taliban capture of Kabul Frimately 7,000 people were still wait- day 'hopefully means an end to strife ing on the other side of Torkham for and internal fighting which has caused ' permission to cross over into Pak- the loss of thousands of life,' the chief istan. He said that about 5,000 peo- minister of Pakistan's North West ple had already arrived in Peshawar. Frontier Province (NWFP), Aftab, "Our job is to provide services to the Ahmad Khan Sherapo, said. newly arrived refugees, whether they Sherapo said he hoped the change in) use the unfrequented routes along Afghanistan would bring about peace the border or have valid documents, which would pave the way for the, we have no concern," the official refugees' retum. 'NWFP has played said.

\section{Jalalabad's fall a serious} set back to refugees repatriation
(UNHCR)'s Executive Committee to be held in Geneva where they are contemplating to take up the issue and seek international assistance.

The border between the two countries is closed since early 94 to discourage further flow of refugees but because of latest novements of Taliban particularly in areas close to the border the influx could not be stopped despite all possible restrictions.

"Despite the sealing of the border the refugees can always cross

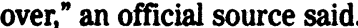

He added, "repatriation will automatically stop when there will be uncertainty in areas close to the border, earlier considered safe".

Under the repatriation programme, the government has encouraged the Afghan refugees to move to Jalalabad by providing with ration and other goods as an incentive. This has resulted in exodus of almost 72,000 refugees so far.

But the movement was reduced to trickle when the fighting among awaited peace' in Afghanistan. different factions in Afghanistan His province has sheltered most of different factions in Afghanistan the more than one million Afghans flared up early this year. However, still living in Pakistan out of nearly the recent advancement of Taliban three million who streamed across in? has resulted in reverse migration. the wake of the 1979 Soviet occupa-

The sources said the tribal belt the wake onded in 1989 with the defeat in general and Southern and North- of the Red Army. ern Waziristan in particular are the But, people in northwest Peshawar, easy openings for the refugees to home to most refugee families, beenter into Pakistan.

lieve many may not be in any hurry to

States and Frontier Region Divi- head back to an uncertain homeland sion (SAFRON) is the relevant after years in Pakistan where they agency in the federal government have established themselves socially which deals with these refugees and and economically. their repatriation. The officials in the division are not happy with the foreign office which according to them, is not properly highlighting the problem of Afghan refugees in Pakistan. These sources say the foreign office is required to show extra cooperation to this agency to resolve this problem which has not only threatened the internal security of the country but has also put extra pressure on country's economy.
NATION

29 SEP 1996

policy to counter this further in the authorities are looking towards the annual meeting of UN High Commission for Refugees 


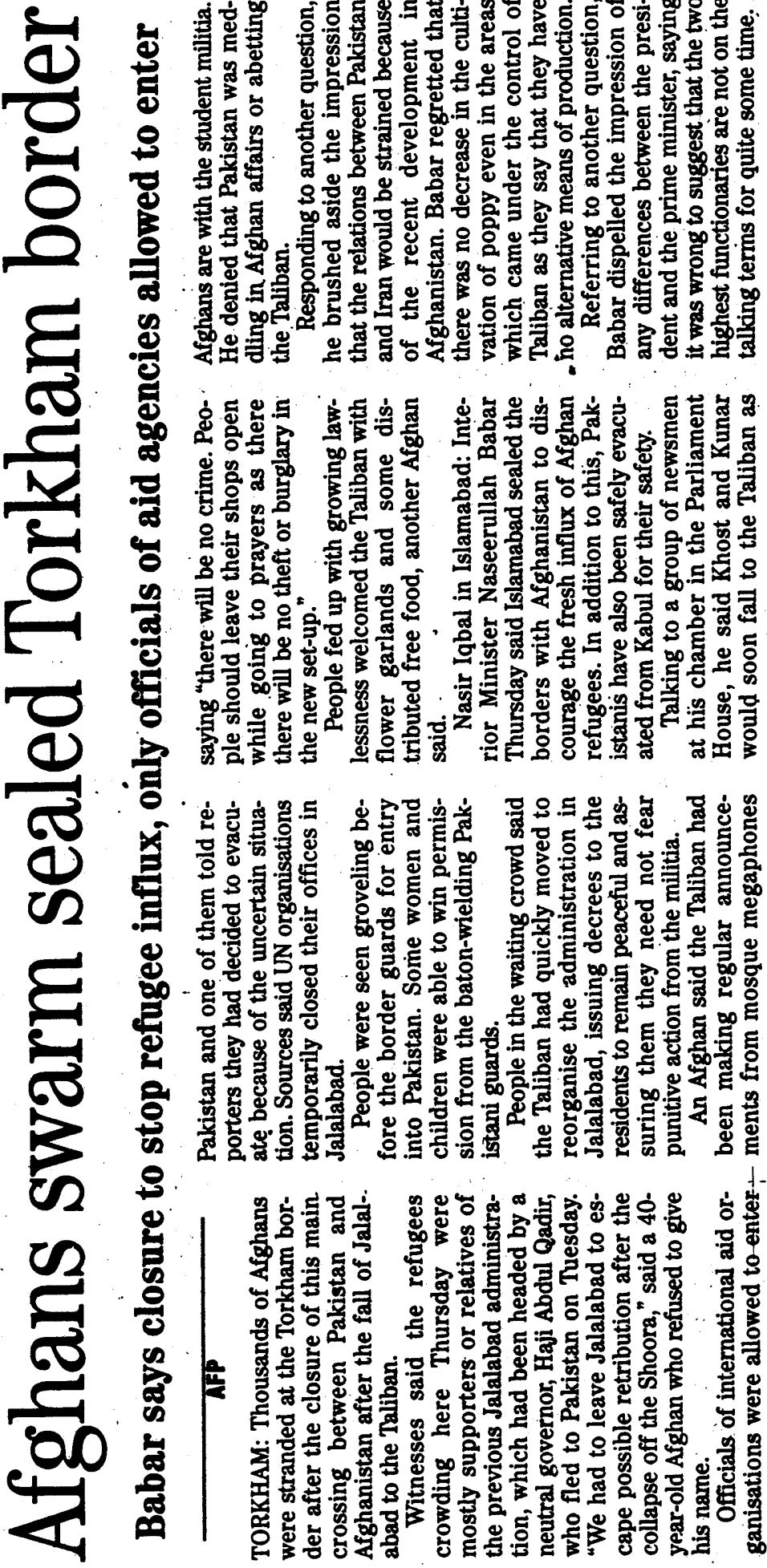

\section{City to have another camp for refugees F.P. Report}

PESHAWAR - Authorities Tuesday decided to establish a new camp in the city for the Afghan refugee families who have arrived from eastern Afghanistan after Taliban overran Jalalabad.

Streams of Afghan families have crossed the porous Durand Line during the past one week after the Taliban attack on Jalalabad, capital of Nangarhar province.

The latest influx of Afghan refugees, whose authentic number is not available, rattled the authorities looking after millions of refugees during the past 14 years.)

At a meeting held at the office of commissioner Afghan reflugees here Tuesday, both Pakistani and UN officials reviewed the latest refugee situation and decided to establish a new refugee camp at Nasirbagh. The meeting among others was attended by J. Moucht. chief de mission of UNHCR in Islamabad and other UN officials.

After assessing the situation in the Pakistani border town of Torkham following the capture of Nangarhar province by Taliban and the impending influx of new refugees, it was decided to make arrangements for the establish ment of a new camp at Nasirbagh refugee camp on emergency basis.

The UNHCR agreed to provide tents for the new camp if there was any such need. The meeting also decided to request different NGOs to provide food and other basic necessities to the uprooted new arrivals from across the bor der.

HRUNTIER PUST

18 SEP 1996

TVNOLYNYGINI SMAN GH.

LSOd UAILNOYA 


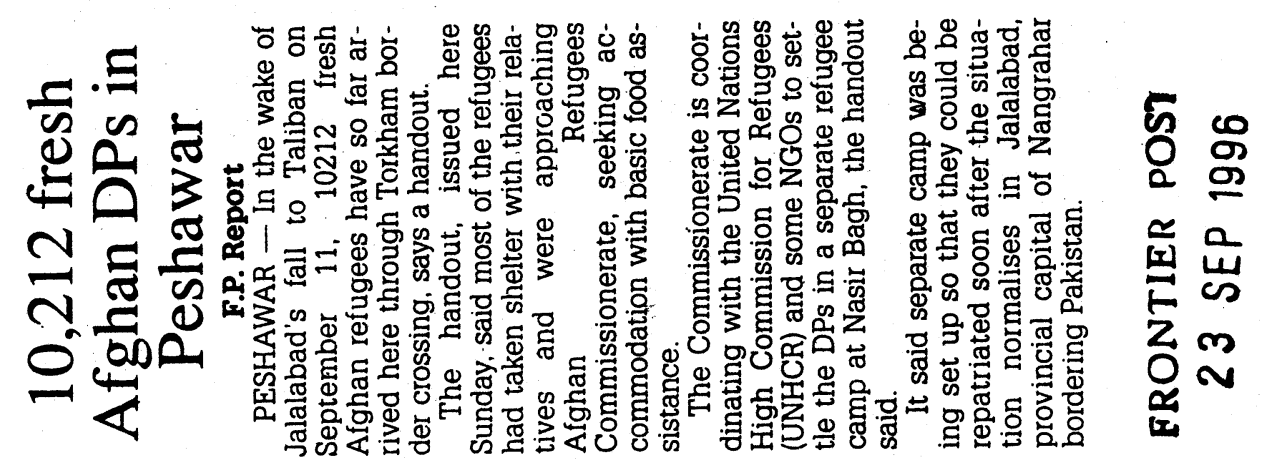

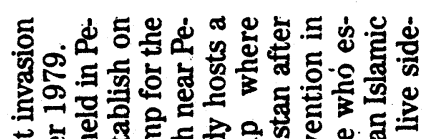

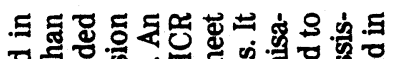

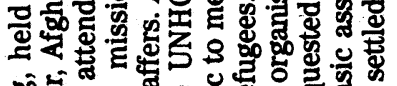

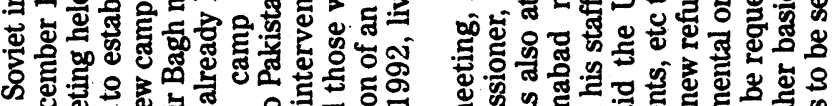

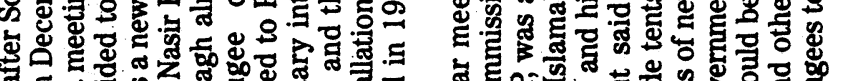

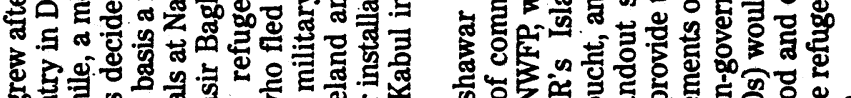

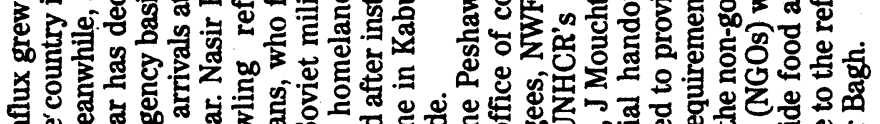

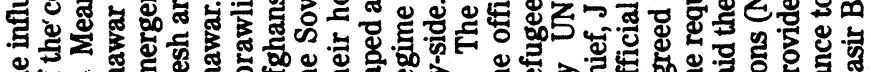

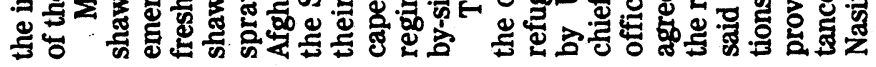

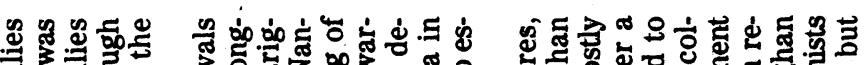

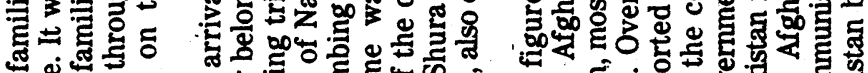

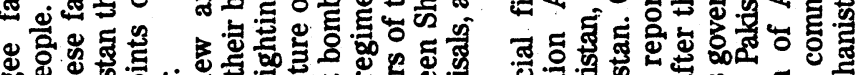

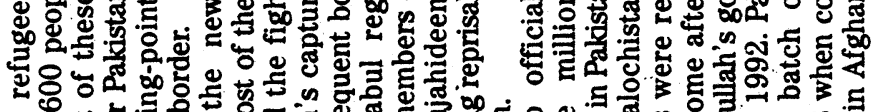

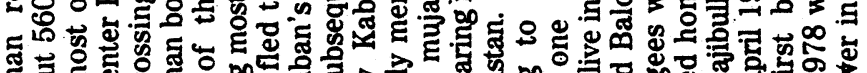

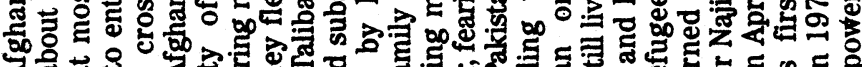

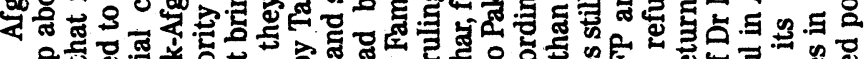

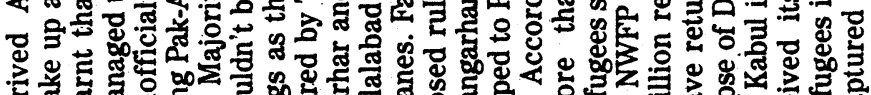

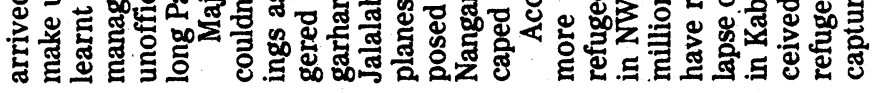

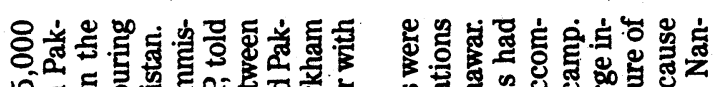

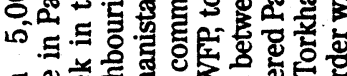
要 (2)

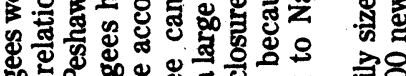
$\infty$

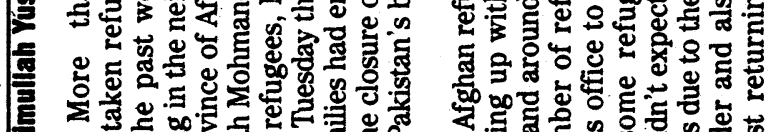

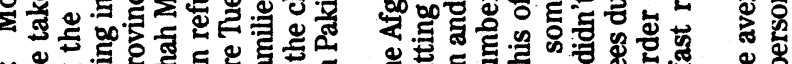
变密

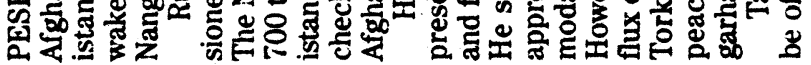

要




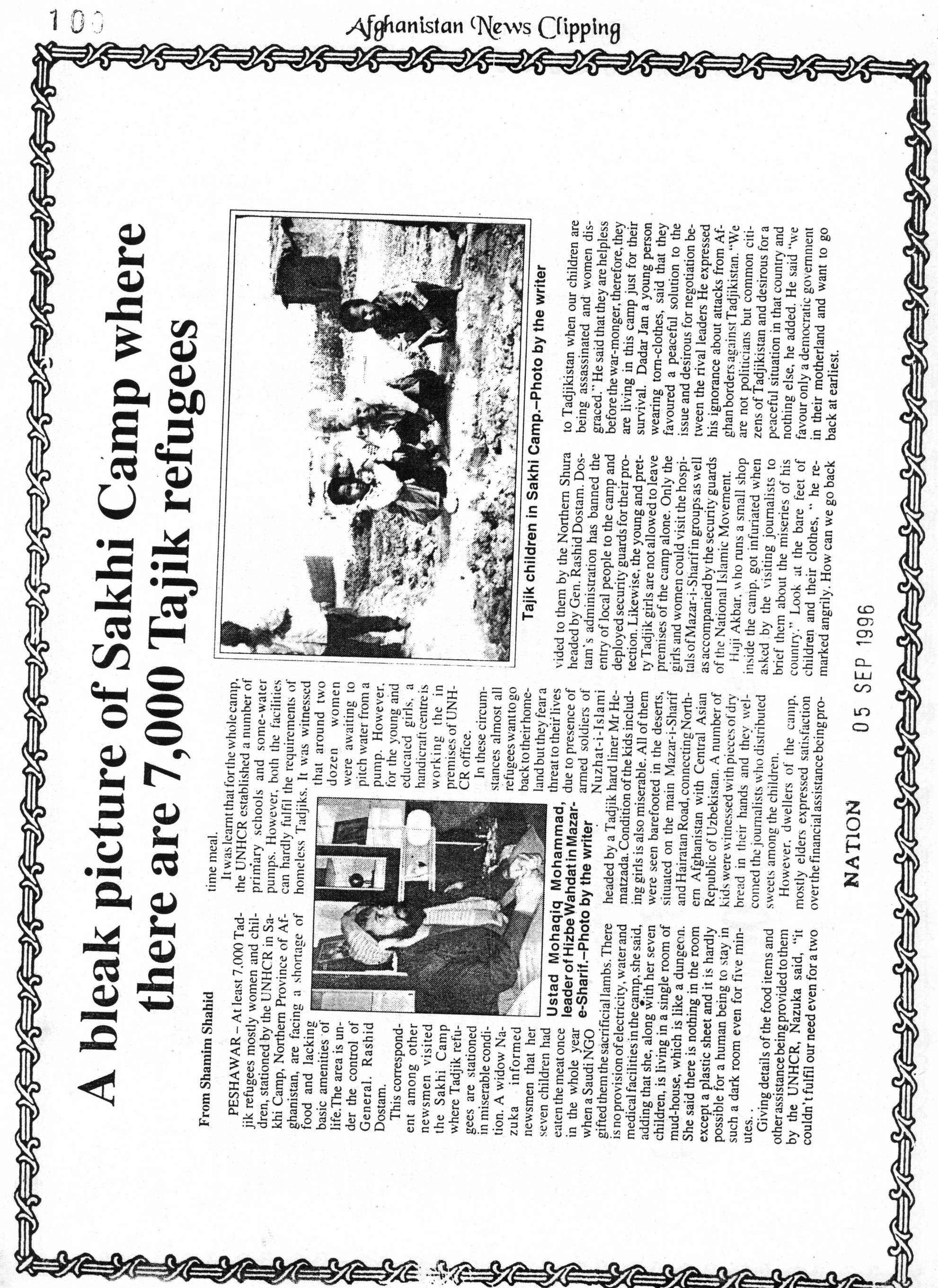


PESHAWAR (NNI)-The government of Pakistan has revised its. hitherto liberal immigration policy towards the Afghan refugees and has introduced stringent measures to check a fresh influx of thousands of refugees seeking to enter Platistan. The new inflow of refúgees has been precipitated by the fall of Jalalabad city to the ultra-orthodox Taliban militia last week.

An official of Pakistani administration, Javed Igbal who is posted at the main border point of Torkhum with Afghanistan said "Under the new policy, no Afghan refugee family who is not in possessiop of valid travelling documents will be allowed to enter Pakistani territory". Authorities have turned back about 50 refugee families who had crossed into Pakistan, after introduction of the new rules.

Troops consisting of Frontier Corps and other militia forces, manning the

Pak-Afghan border are stopping the Afghan refugees from crossing over to Pakistan under the new policy of the Interior Ministry Just $20 \mathrm{~km}$. from Jalalabad Chahar Bog o f he a bloody battle between Tâliban niltiag and $\mathrm{K}$. bul forces is under way, the new itegi lations have left about 8,000 Afghá refugees stranded on the Afghan side of the Torkhum border. Eye-witnesses say that the armed Taliban militia leaders came close to a clash with Pakistani border forces as they tried to forcibly open the border but fortunately the matter ended with an exchange of harsh words only.

According to estimates, despite the new tough rules introduced by Pakistan, about 5,000 Afghan refugees have entered Pakistan. Even as Pakistan attempts to restrict the movement of new refuget families, there are reports that many bf the new refugees have already joined their friends and relatives settled in Pakistan.

The United Nation's High Commission for Refúgees (UNHCR), has once again prepared the refugee camp of Nasir Bagh for the new wave of refil. gees on Torkhum border point, but only few unlucky could be thrown into that camp, as thousands of others on tered Paldstan through those border points which according to Pakistani officials are not humanely possible to be manned. Nasir Bagh, a vast ground had earlier played host to most of 3.5 million Afghan refugees which took shelter in adjacent Pakistani province of NWFP through Torkhum border point. They had spread out all over Pakistan owing to the flexible policies of the successive regimes, and adding to the misery of law enforcement agencies. Owing to the incidents of terrorism in Pakistan, the Pakistani administration was forced to hant for Afghan nationals who were rounded up and thrown in lock-ups from major cities of Pakistan whenever some blast occurred.

The Kabul administration led by President Burtanuddin Rabbani has also renewed its allegation that Pakistan was helping Taliban militia. Radio Kabul in its Pushto commentary had described Taliban forces as "Babar's pupils", a hint to earlier allegations that Pakistan's Interior Minister Nasirullah Khan Babar created the militia, an allegation vehemently denied by the minister. The radio said that the students of Kabul University held a protest rally against what they said was the "Pakistani militia's" occupation of Jalalabad. As they gathered outside the Kabul's Defense Ministry building, they demanded weapons so that they could defend their homeland from the enemies, which currently is restricted to Afghan capital of Kabul.

\section{Najib's men face threats to life in Peshawar}

\section{From Our Correspondent}

PESHAWAR - The reconciliation between Hikmatyar and Prof Rabbani has caused serious trouble for those Afghans who worked on important posts during the previous government of Dr Najib Ullah.

Some highly-placed sources told The Nation that both the hardliners have directed their staliwarts to arrest or kil those Afghans who served in Najib govemment. Such people had fled to Pakistan and at present are living in Peshawar faced with serious financial problems. They have lost hope of returning to their homeland and are shifting to other Pakistan cities fearing for their life in Peshawar.

Amongst these Afghans one was identified as Mr Jamal Shah Usmanzai a former political officer of Afghan Army. After the fall of Najib Government Usmanzai migrated to Peshawar and was arrested by the Hizbe Islami (Hit matyar) troops. He was detained at Charsiab and Speena Shaga, where the Hizbe Islami had set-up its own prisons. However, he escaped from Charsiab in early 1995 when Taliban attacked the Hizb militia. Recently NATION
Jamal Shah Usmanzai has received several threats from the hardliners of Hizbe Islami. "Even the armed Hizb activists fired on his residence and made several attempts to kidnap him, one of his relative said. At last, Usmanzai decided to shift to an other city along with his family. He is not in Peshawar but is still receiving threats from Hizbe Islami of Gulbadin.

Similarly, Brig. Yassen, another Afghan who was captured by Jamiat Islami, Shura-i-Nazar and Hizbe Islami is now facing threat. Like Usmanzai, he also decided to leave Peshawar either for Punjab or for Sindh. Asad Ullah Nawabi, a former military office after escaping several murder attempts has left his family at Peshawar and disappeared. His family members are being harassed by the-armed activists of all three coalition partners along with Ittehad Islami of Prof Rasool Sayaf.

A number of Afghans, when contacted have confirmed such threats to the lives of former civil and military officers. They said that responsibility rests with the Pakistani authorities to take a notice of the matter and protect these war-affected people. 


\section{Hekmatyar denies accusing Pakistan}

\section{By Mariana Baabar}

ISLAMABAD: In a bid to do some quick damage control, Afghan Prime Minister Gulbadin Hekmatyar has strongly denied a statement attributed to him that Pakistan was supporting the Taliban in their new military offensive and that the student militia had moved into Jalalabad from Torkham.

A spokesman for Hekmatyar in Islamabad, Abdul Saboor, told The News, "The authorities in Kabul have been in touch with me regarding a report carried by some news agencies that Prime Minister Gulbadin Hekmatyar had accused Pakistan of supporting the Taliban. This is absolutely baseless and we completely refute and reject this statement attributed officially to the Afghan Prime Minister. The Prime Minister's office has instructed me to state that as yet Gulbadin Hekmatyar has made no statement regarding the recent developments inside Afghanistan."

The spokesman at the Foreign Office when contacted about this development said, "The earlier statements regarding Kabul's allegations were completely unfounded and it was certainly not a correct charge. We are now happy to know that the Afghan Prime Minister has himself denied these charges which were a misconceived notion at best." Pakistan insists that the Taliban captured Jalalabad from Hisarak without any resistance or bloodshed and that Pakistan had closed the Torkham border two days before the hostilities broke out and no movement from either side was allowed.

Earlier, it was President Burhanuddin Rabbani who had blamed Pakistan of supporting and facilitating the Taliban in their fresh offensive. However Islamabad remained unprovoked and announced that its Foreign Secretary, Najmuddin Sheikh would not postpone his visit to Kabul on September 19.

The recent thaw in relations between Kabul and Islamabad had the strong support of Hekmatyar of whom a senior official in Islamabad said, "At least we now have someone in Kabul we can talk to." But with the strong allegations from Rabbani, it is easy to see that Hekmatyar's position was being compromised and he quickly distanced himself from the views held publicly by the Afghan President.

\section{War no solution to Afghan problem: Hekmatyar}

ISLAMABAD: Afghan Prime Minister Gulbaddin Hekmatyar has said no one can forcibly rule Afghanistan and fighting was no solution to the Afghan problem.

"Taliban should not repeat this failed experience and they can not militarily impose their will on the people of Afghanistan," Hekmatyar told BBC Pushto Service in an interview from the Afghan capital Kabul.

The Afghan premier declared: "The people of Afghanistan will not accept any government which will be forcibly imposed on them. We will resist and foil any such attempt." He said all parties in Afghan coalition government were jointly defending Kabul and all leaders were present in the capital.

Meanwhile, Hizb-e-Islami Afghanistan (HIA) has categorically rejected press reports that Prime Minister Gulbaddin Hekmatyar has left Kabul for Mazar-e-Sharif. The HIA spokesman in Islamabad, Abdul Saboor, described the reports as malicious and unfounded. - PPI

\section{SEP 1996}

\section{SEP 1996}

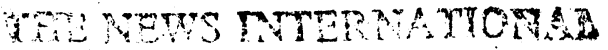




\section{ANLF welcomes former king's intentions, Hezb may soften opposition}

\section{Bureau Report}

PESHAWAR: The Taliban and Sayyaf's Ittehad-i-Islami on Saturday rejected any role for Zahir Shah, saying he was unacceptable to them as well as to other groups in Afghanistan as a figure-head to lead an interim arrangement. Prof Mojaddedi's Afghan National Liberation Front welcomed the former king in exile in his efforts to restore peace in Afghanistan.

Maulvi Amir Mutaqqi told The News from Qandahar those seeking to resolve the Afghan conflict should join the Taliban movement which under the leadership of Amirul Momineen' Mullah Mohammad Omar Akhund who had considerably solved the problems of a large portion of Afghan populace. "If he intends to find his way through negotiations with groups who had bloods on their hands of innocent Afghans or has some other programme up his sleeve. He is also unacceptable to us", he said. "He can join us as an ordinary Afghan", he insisted.

Sayyaf's Ittehad-i-Islami has in a message from Kabul also denounced the former Afghan king and said his party was not prepared to concede any role to him.

Former Afghan President Sibghatullah Mojaddedi's ANLF in a communique issued here said the party had long held that it was inalienable right of the former kind as an Afghan to play his due role in restoration of peace and normalcy in Afghanistan and would support all steps taken by him for the resolution of the lingering civil-war in Afghanistan.

Hikmatyar's Hezb-i-Islami has chosen to keep quite for the time being but the party's anti-Zahir Shah stand is too well known, though a Hezb source indicated it might soften its stand 'a little bit', on the question of Zahir Shah whose spokesman told the BBC and VOA he might end his 24 years in selfexile and return home in two weeks time.

Meanwhile, the Taliban high command nominated Mullah Mohammad Rabbani as the head of Eastern Shura and Mullah Mohammad Tahir Anwari as the new Governor of Nangrahar, a communique issúed here said.

In another development, the Taliban resumed transmission of radio Nangrahar, closed down a day before the students militia captured Jalalabad.

Maulvi Mohammad Ishaq Nizami told The News the radio unlike the past would have morning and evening transmissions, featuring news and Islamic programmes.

Another report said the Taliban flew into Jalalabad, a helicopter, found abandoned in Laghman's Kargha district by the retreating Hezb-i-Islami forces.

\section{Former Afghan President hails Taliban victory}

KABUL (AFP) - Former Afghan president Sibghatullah Mojaddedi Saturday welcomed the victory of the Taliban Islamic movement, saying he hoped it would signal a 'bright future' for Afghanistan.

-We hope that with the victory of the Taliban Islamic Movement our Muslim nation would witness a bright future by leading a peaceful and prosperous life within the framework of truly Islamic govermment,' he said.

The comments of Mojaddedi, who was president in April and June 1992, came in a slatement released from his home in Peshawar, on the Afghan border.

The former president said he supported the Taliban. a day after they took Kabul and ousted the coalition government of his former mujahedeen colleagues Burhanuddin Rabbani and Gulbuddin Hekmatyar.

But, accusing Rabbani of having clung to power in defiance of the national $\backsim$ ddedi said he and his compis $\quad$ uld now support the leaders: 'pious Moslem' elected by a majority.

'We wou: the leadership of a pious, : lem elected by the majority tfighan nation and who has . narticipated in our 14 yeai var) against (1979-89) the 5 ... on and communism,' he said. Mojududid, whopresided over the transition to mujahedeen rule in Kabul in April 1992, nevertheless urged the Taliban leadership tobe tolerant. 'We expect that the Taliban Islamic Movement would demonstrate pa- tience, tolerance and forgiveness by solving the issues confronting our country through talks and negotiations keeping in consideration the due rights of all citizens.' One of the Taliban's first actions on taking Kabul was to hang former Afghan president Najibullah.

Mojaddedi, who leads Jabbah Milli Afghanistan or the National Liberation Front, said the Afghan nation had suffered a civil war because Rabbani 'did not respond positively' to the advice of former partners and others.

- By failing to transfer power peacefully to the will of the nation, the regime (of Rabbani) caused the killing of thousands of our compatriots and steered the country towards total destruction and annihilation,' he said. 


\section{Afghanistan: UN}

F.P. Bureau Report

ISLAMABAD - The undersecretary general of the United Nations for political affairs. Marrack Goulding has asked the countries Afghanist to earnestly work for bringing rival Afghans warlords into an alliance for durable peace in that War-torn country.

Goulding was addressing a news conference hère $\cdot$ Monday at UN Information Centre after returning from a four-day visit to Afghanistan, where he held parleys with leaders of different Afghan groups and government functionaries.

Goulding said that the United Nation was trying to bring the rival warlord into an alliance, and hoped that the neighbouring countries would also help it (the UN) in bringing the much desired peace in Afghanistan.

The UN under-secretary general informed the newsmen that he and, Dr Holl, the head of the United Nations special mission to Afghanistan, during their four-day visit to the war-torn country met leaders of different Afghan groups for evolving a strategy that how the UN could reinvigorate its peace making efforts in Afghanistan.

Goulding said that the "UN secretary general is concerned at the fall in voluntary contribution

\section{uN envoy calls for ceasefire in Kabul}

\section{By Our Correspondent}

ISLAMABAD, Sept 25: The Head of the United Nation Special Mission to Afghanistan, Dr Norbert Holl, urgently appealed to all factions involved in the Afghanistan co fighting to observe immediate of ceasefire amid reports that the Taliban militia have captured a government stronghold Sarobi W on Tuesday night and now the fighting is raging in the suburbs of Kabul.

"I therefore, once again urgently appeal to all the factions involved in the ongoing conflict in Afghanistan to observe immediate ceasefire, refrain from further use of military force to resolve their problems and to begin earnestly and seriously negotiations for a lasing political settlement and peiace in their country," the UN special envoy said in a statement issued here on Wednesday.

"My message is spare the lives of to the UN's humanitarian and relieves that it will be difficult to reverse this trend unless a convincing peace process can be established".

He informed that during his four-day visit, he met Professor Rabbani, Gulbadin Hekmatyar, commander Ahmad Shah Kabul coalition. they also met Gen Dostum and a representative of Khalili, besides meeting a delegation of the Taliban leadership led by Mullah Abbas.

The UN envoy told the newsmen that though the visit to Afghanistan coincided with the Taliban offensive against Jalalabad, adding, "this undera political process to resolve the differences between the various parties in Afghanistan".

$\mathrm{He}$ said that the fall of Jalalabad has generated intense diplomatic activity in Afghanistan and in the neighbouring countries and hoped that the United Nation could take advantage of this to enlist the help of all concerned in persuading different Afghan parties to give up the military option and agree to a negotiable settlement. habilitation programmes and beMasood and other leaders of the

The UN envoy disclosed that lined the urgency of establishing already suffered enough from years of useless bloodshed," he said.

Dr Holl urged those-countries with influence in Afghanistan to persuade the warring parties to abandon the course of war and cooperate with the United Nations in a genuine search for a sustainable resolution to the Afghan tragedy.

He said he had been following with increasing concern the recent developments in Afghanistan.

He said the United Nations was particularly concerned at the determination of the warring parties to resort to military means to resolve the problems of the country, rather than starting peaceful negotiations in a genuine spirit of reconciliation and mutual accommodation

"These developments are all the more regretful as they are happening when the United Nations is intensifying its peace efforts in the
Goulding to visit Afghanistan. from 10th

ISLAMABAD (PPI) - The UnderSecretary-General for Political Affairs, Mr Marrack Goulding, will be paying an official visit to Afghanistan fróm September 10 to 17 .

During this period, he will travel to Kabul for talks with President Burhanuddin Rabbani and Prime Minister Gulbuddin Hekmatyar and to Mazar-e-Sharif and Sherbaghan to meet Gen. Rashid Dostum and senior members of the National Islamic Movement of Afghanistan (Nima): to Kandahar to meet with the leaders of the Taliban: and to Jalalabad for discussions with Governor Haji Abdul Qadir and his shura.

On his way to Afghanistan, $\mathrm{Mr}$ Goulding will stop over in Islamabad to consult with senior Pakistan government officials dealing with Afghanistan, and with the ambassadors of the countries interested in Afghanistan. He will also meet the heads of the United Nations agenciés operating in Afghanistan

The purpose of the Under-Secretary-General's visit is to assess the prevailing political situation in Afghanistan in the context of the prospects for negotiated peace in the country and to offer encouragement and guidance to the United Nations special mission of Afghanistan under the leadership of its head Dr Norbrt Holl.

On return to New York, Mr, Goulding will report to the Secretary General of the United Nations, Boutros Boutros-Ghali and brief the Secretary Council on the prospects for a lasting political settlement in Afghanistan and the progress of work of the United Nations special mission.

\section{Holl proceeding to Kabul to settle crisis}

ISLAMABAD (Agencies) - The special United Nations' representative Norbert Holl is travelling to Kabul to try to settle the continuing crisis in Afghanistan, Voice of Amer ica reports.

Mr Holl and his delegation will also go to Jalalabad.

The Taliban captured Jalalabad on Wednesday. The capture of JalaTabad is a setback to the government 'of President Rabbani.

Pakistan has closed its border due to the latest fighting. About 5,000 Afghan refugees fleeing Jalalabad àc asking Pakistani officials to let them enter.

\section{NATION}

$$
14 \text { SEP } 1996
$$




\section{Holl shocked} over execution

ISLAMABAD (PPI) - The head of the United Nations special mission to Afghanistan Dr. Norbert Holl has deplored the execution of former Afghan president, Dr. Najibullah and his brother, by Taliban in Kabul on Friday morning.

"The abduction and execution of former Afghan president and his brother from the UN compound in Kabul by armed men without any legitimate judicial procedure not only constitute violation of the immunity enjoyed by UNSMA but also further jeopardise all the efforts being made to secure a peaceful settlement of the Afghan conflict" Dr. Holl said in a statement issued here Friday.

Expressing deep regret over public exposure of the dead bodies of Najibullah and his brother, he said UNSMA deeply deplored these tragic events which cast a doubt over the willingness of those responsible to achieve reconciliation.

Paying tributes to late Najibullah, the UN envoy said he (the former Afghan president) made a considerable contribution to the peaceful transfer of power to the Mujahideen in April 1992 adding that the UN secretary general, in recognition of Najibullah's contribution had granted him and his companions protection in the UNSMA's premises in Kabul for over four yeals.

He recalled that in recent days UN had marle sisenuous efforts for humanitarian reasons to find a solution to the case of Dr. Najibullah so that he could return safely to his family.

FRONTIER POST

NATION

28 SEP 1996 and negotiate, laying down the arms option.

He said no arms embirgo seemed feasible since Kabu as opposed to any such move po a out that vast Afghan border to. ing several other states, could not be adequately policed to prevent arms being smuggled to various fighting groups and factions. 


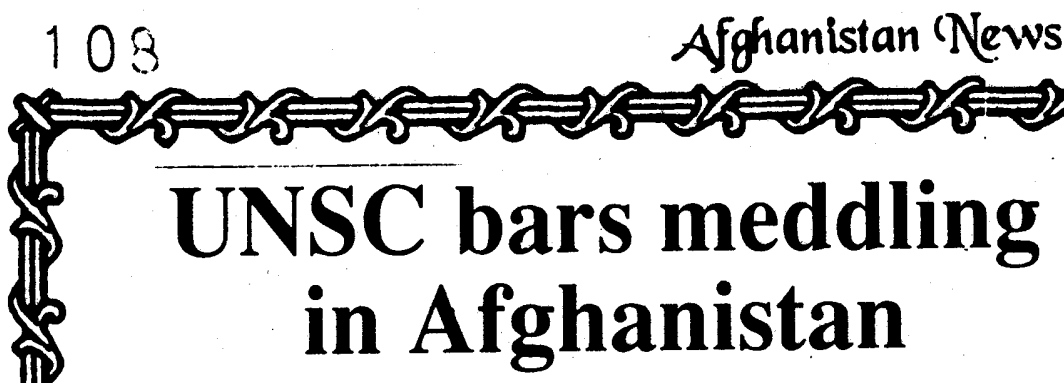

UNITED NATIONS (AFP) - Rabbani The UN Security Council on Saturday called on "all states" to refrain from interfering in the in10 ternal affairs of Afghanistan folOn lowing the capture of Kabul by the Taliban Islamic militia.

In a formal statement reflecting a consensus among all 15 members, the council also expressed "dismay at the brutal execution by the Talihan" of former Soviet-backed! president Naijbullah.

The council expressed concern at the violation of UN premises in

- Kabul. Najibullah and his brother Shapour Ahmedzai were forcibly taken from the UN compound and summarily executed following the fall of Kabul to the Taliban early Friday.

Their battered bodies were hung in a central Kabul square on public display.

The statement called on "all states to refrain from interfering in the internal affairs of Afghanistan."

This was seen as an indirect message to neighbouring Pakistan, which denies backing the Taliban, but also to India, Iran and Russia which were considered close to the coalition government of President Burhanuddin
The Afghan government fled north ahead of the Taliban offensive on Kabul.

It called for an immediate end to the fighting, and for apolitical dialogue aimed at achieving national reconciliat

A report from Kabul said United Nations special envoy for Afghanistan, Norbert Holl, ended preliminary talks with the new Taliban rulers of Kabul Sunday, as the city came to grips with its new Islamic regime.

Holl emerged from talks with members of the ruling council and was tight lipped about the discussions.

He declined to say if he had protested against the execution of former communist president Najibullah by the Taliban religious militia last Friday.

"I think all necessary has been said," was his only comment.

On the Taliban's ban on women working outside the home, Holl said the issue had been discussed two weeks ago with the Taliban in their southern head. quarters Kandahar.

"You will understand that on my first visit to Kabuil I could not discuss all these issues in detail," he said

UNITED NATIONS (AFP) - UN
Secretary-General Boutros Boutros Ghali on Friday deplored the "terrible loss of life" in the batthe for Kabul and the viclation of UN immunity protecting former ex-communist

president

\section{Najibullah.}

Boutros-Ghali "finds it particularly regretful that a person who had sought sanctuary in UN premises was abducted from UN premises, which is a breach of the invioliability of UN premises," his spokeswoman Sylvana Foa told a news briefing.

She noted that Boutros-Ghali had been engaged "for a long time" in personal negotiations with the government of President Burhanuddin Rabbani to secure a safe passage out of the country. The talks were "not successful."

"The government responded that this was a national problem and that his fate was up to the Afghan people," she said.

Foa added that Najibullah had refused UN requests to move him elsewhere, even the most recent request on Wednesday, saying that "he felt safer" in the UN compound.

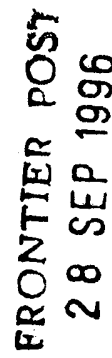

\section{UN concerned over Afghan fighting}

\section{Agencles}

UNITED NATIONS: The UN Secretary Council held its formal session to consider the situation in Afghanistan and decided to issue a Presidential Statement. None of the 15 members of the Security Council had any objection. The formal meeting of the Council lasted for four minutes only.

Russian Federation wanted the Council to adopt a resolution, but later agreed to a presidential statement. The Council also dropped the wording, which expressed Council's grave concern about "the takeover of the capital city of Kabul' and confined its grave concern about the military confrontation in Afghanistan, only.
Presidential Statement of the Security Council reads as following:

"The Security Council reiterates its grave concern about the military conf. Jntation in Afghanistan. The Security Council is also concerned at the violation of the United Nations premises in Kabul and expresses its dismay at the brutal execution by the Taliban of the former Afghan president. Najibullah, and others who had taken refuge in these premises.

"The Security Council demands that all parties fulfil their obligations and commitments regarding the safety of the United Nations personnel and other international personnel in Afghanistan. It calls upon all Afghans to cooperate fully with the
United Nations and associated bodies as well as with other humanitarian organisations and agencies in their effort to respond to the humanitarian needs of the people of Afghanistan.

"The Security Council reaffirms its commitment to the sovereignty, independence, territorial integrity and national unity of Afghanistan.

"It calls for the inmediate cessation of all armed hostilities and urgently calls upon the leaders of the Afghan partics to renounce the use of force to put aside their deferences and to engage in a political dialogue aimed at achieving national reconciliation. The Coum il also calls upon all states $(0)$ refrain from interfering in the internad allairs of Alghtanistanl. 
WASHINGTON (AFP) - The United States called on the Taliban Islamic militia Friday to form a representative government in Kabul dedicated to reconciling Afghanistan's warring factions.

"We hope that this presents an opportunity for a process of national reconciliation to begin," State Department spokesman Glyn Davies said.

Vurshington also saud it regret ted the death of former Afghan president Najibullah who was abducted from the UN compound in Kabul and hanged with his brother in a street nearby.

But the State Department did not condemn the extra-judicial killing and refused to rule out the possibility that it may establish diplomatic relations with a Taliban-dominated government in Kabul.

"l am not going to prejudge where we're going to go with Afghanistan," Davies said.

"Our hope at this stage is that the new authorities in Kabul will move quickly to restore order and security and to form a representative interim government that can begin the process of reconciliation nationwide," he stated.

The takeover by the ultra-orthodox Sunni movement came one week after US diplomats visited Taliban leaders in their stronghold of Kandahar in southeastern Afghanistan.

The diplomats pressed the Taliban to hold peace talks with rival factions under the aegis of the United Nations, a State Department official said.

The United States considers the United Nations to be the main venue for launching a peace pro cess and has urged countries in the region, including Pakistan, to refrain from interfering in the conflict.

Although Davies indicâted that the Taliban takeover could advance the cause of peace in Afghanistan, other officials said it remained unclear whether the new regime could bring tangible improvements.

An official noted that in areas controlled by the Taliban, there has been more safety and order than in those under the rule of rival factions.

"But on the other hand, they also stone people to death," he commented.

As Sunni fundamentalists, the Taliban were seen as different from their Shiite counterparts in Iran who dominate the fiercely anti-western regime in Tehran.

\section{US diplomats visit Afghan Consulate in Peshawar}

\section{From Our Correspondent}

PESHAWAR - Two senior American diplomats in Pakistan visited the Peshawar-based Afghan Consulate General and held a detailed meeting with their counterparts from Afghanistan.

A local Pushto daily states that the American diplomats who visited the Peshawar-based Afghan Consulate included Cultural Attache at Islamabad and Vice Consulate Peshawar. Both of them held detailed negotiations with the senior Afghan diplomats. Details of the negotiations are yet to the ascertained. The Pushto daily states that diplomats from both sides United States of America and Afghanistan discussed ways and means to reactivate America's diplomatic activities regarding cultural affairs. They also discussed the educational activities in the warravaged Afghanistan and the Americans apprised themselves about the infrastructure for sponsoring the education programine.

Writ petition itdmitted

A2-memberbencit Peshawar High Court admitted a writ petition challenging arrest of Mohammad Nawaz, a property $d$-aler from abbottabad under $3 \mathrm{MPO}$ and ordered to produce the record of the case on Sept. 8.

The arrested property dealer is said to be a hurdle in a project launched by Qazi Mohammad Jamil and his brothers . 


\section{Iranian Press sees US, Saudis and Pakistan behind Taliban}

TEHRAN (AFP) - Iranian newspapers voiced displeasure on Saturday over the fall of the Afghan capital to the Islamic Taliban militia, charging that the United States had facilitated the takeover.

Most of the newspapers alleged that in addition to the United States, the Taliban was also actively backed by Pakistan and Saudi Arabia.

The militia's capture of Kabul on Friday was 'designed by Washington, financed by Riyadh and logistically supported by Islamabad,' said Jomhuri Islami, a daily close to Islamic hardliners.

It predicted that the ultra-conservative Sunni Muslim Taliban would be incapable of running Afghanistan and will be used to pave the way for another group to take over.'

'All signs indicate that this will not be the last government in Kabul and the next group may not even have to find itself (in power) through military force, but political dealings,' the paper added.

The English-language Tehran Times urged the Taliban to start a dialogue with other Afghan factions 'to prevent further bloodshed.'

'Taliban's objective has always been to create a new brand of an Islamic government. It has now the opportunity to prove its sincere intentions and create an atmosphere of peace,' it said.

'With their violent methods, the Taliban can neither run the country nor gain the support of their people or foreign powers,' said the moderate daily Hamshahri. 'The hanging of Najibullah has drawn the rage of the international community.'

Former Afghan President Najibullah, who led the Soviet-installed regime in Kabul until his government collapsed in April 1992, was abducted by Taliban fighters from the UN compound in Kabul where he had lived for the past four years and hanged along with his brother.

Iran had good relations with the former Kabul government and was strongly opposed to the Taliban's advance on the capital. It had launched

\section{NATION}

\section{SEP 1996}

an intense diplomatic drive to broker a peaceful settlement to the Afghan conflict.

Tehran is highly distrustful of the Taliban and was alarmed when the militia captured territories in western Afghanistan bordering Iran in September 1995.

The Islamic republic is particularly concerned that the Taliban rise could pave the way for greater influence there by its arch-enemy, the United States.

Washington refused on Friday to ruleout the possibility thatitmay establish diplomatic relations with a Taliban-dominated govemment in Kabul.

The takeover of Kabul came one week after US diplomats visited Taliban leaders in their stronghold of Kandahar in southeastem Afghanistan.

The diplomats pressed the Taliban to hold peace talks with rival factions under the aegis of the United Nations, a State Department official said.

\section{Iran sends peace mission \\ to Taliban}

TEHRAN (AFP) - A high-level Iranian delegation left here Wednesday for Afghanistan to discuss peace in the war-torn country with the Taliban Islamic militia, Iran's official news agency IRNA reported.

The Taliban militia the same day said it had taken control of the eastern Afghan city of Jalalabad, Afghan Islamic Press reported. Kabul conceded the fall, accusing Pakistan of direct involvement.

Tehran is alarmed by the rise of the Taliban religious movement in southwestern Afghanistan along its eastern border, and has cited worries over the militia's alleged involvement in drug trafficking from Afghanistan to Iran.

The militiamen control about half of the country and have been besieging Kabul for almost a year, seeking to topple the government and set up a fundamentalist Islamic state.

The Iranian mission, led by Deputy Foreign Minister Murteza Sarmadi, is part of an intense diplomatic drive launched last year to end the civil war in the neighboring country and to get the Taliban to join the peace process.

Earlier the government in Kabul sain its troops had entered Jalalaiad, the capital of Ningarha: province, after the collapse of the provincial ruling council led by a neutral governor, Haji Abdul Qadir.

Qadir fled to Pakistan on Tuesday, while his successor and two colleagues were reported shot dead Wednesday.

Iran's state radio warned on Wednesday that Taliban's advance on Ningarhar "violates the neutrality of the territory and provokes a new wave of bloodshed and homelessness."

It interpreted the move as a "passive response to Kabul's peace diplomacy, in which the militia foels it has no place."

The fundamentalist group "feels itself isolated in the political scene so it tries to reclaim its place by showing off its military muscle," the radio charged.

Sarmadi, during his two-day visit to the southern city of Kandahar, will discuss "issues of mutual interest, mainly problems in Afghanistan" with top-level Taliban officials, IRNA said.

Another Iranian deputy foreign minister, Allaeddin Borujerdi, announced the decision to dispatch a mission to Kandahar during a visit to Kabul in late July.

Sarmadi himself visitod Kabul last week to hold talks with President Burhanuddin Rabbani and Prime Minister Gulbuddin Hekmatyar.

He also travelled to the central Afghan capital of Bamian to meet Karim Khalili, the leader of the Shiite Muslim opposition Hezb-iWahdat and northern Mazar-iSharif to hold talks with Uzbok warlord General Abdul Rashid Dostam.

Sarmadi's trip to Kandahar coincided with a visit here by Afghan Deputy Poreign Minister, Abdulrahim Chafurzi.

The Afghan deputy minister. who travelled to Uzbokistan. Tajikistan and Russia belore coming to Iran on Tuesday, is here to discuss the holding of a regional conference on Afghanistan in Tehran.

\section{ERONTIER POST}

12 SEP 1996 


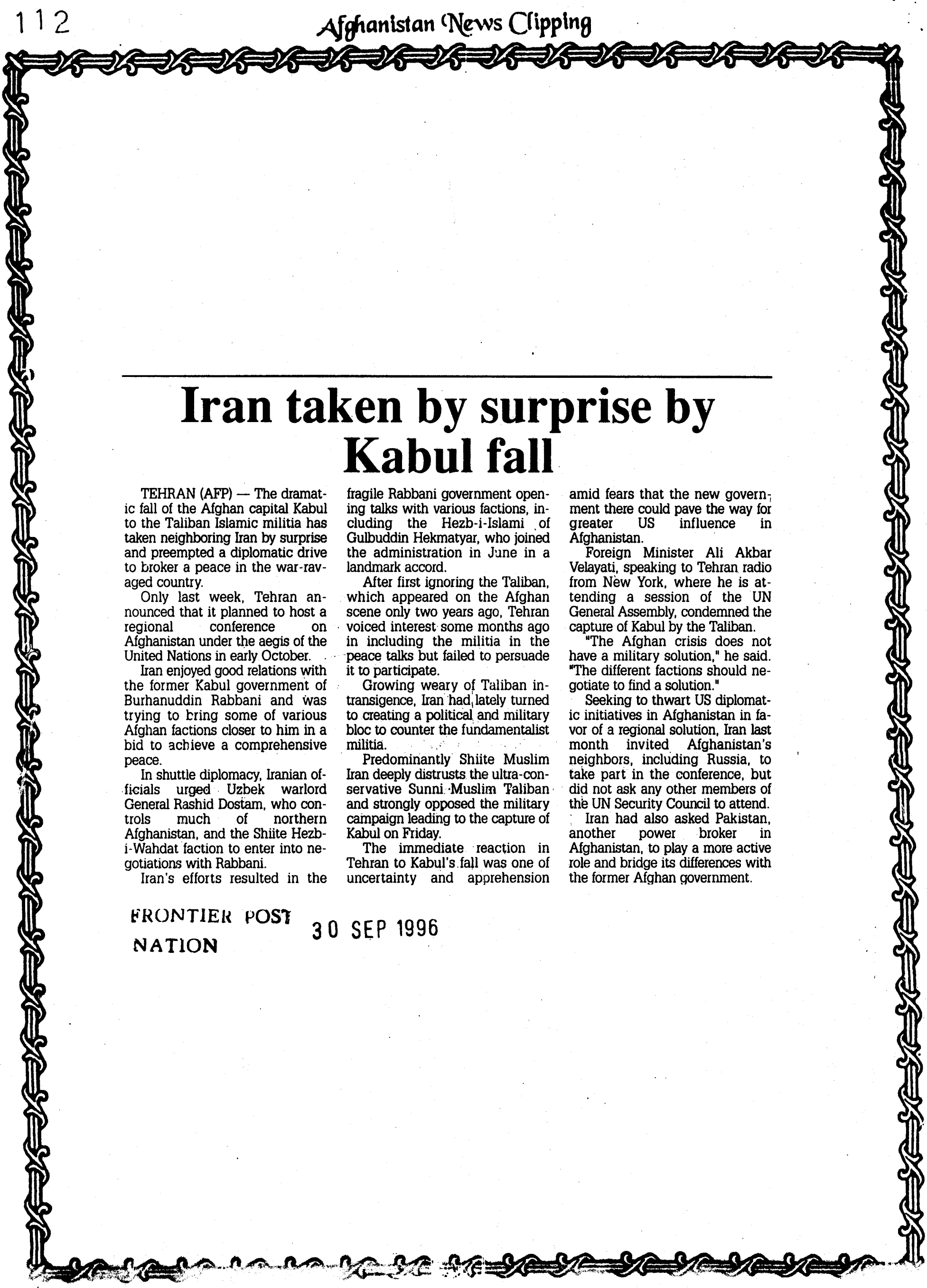




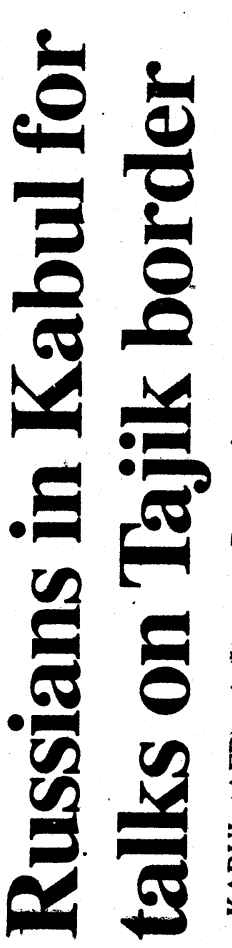

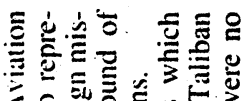

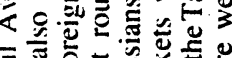

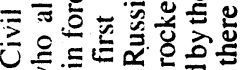

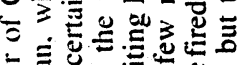

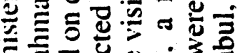

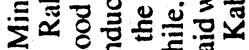

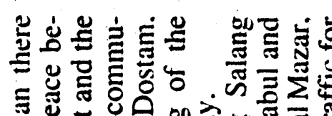

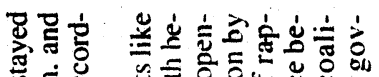

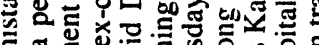

语语

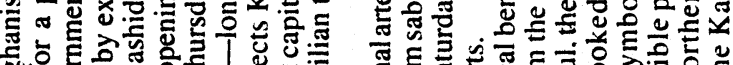

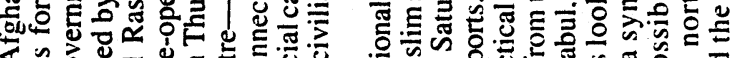

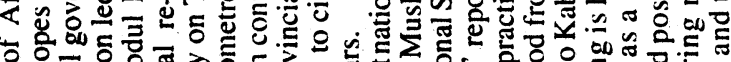

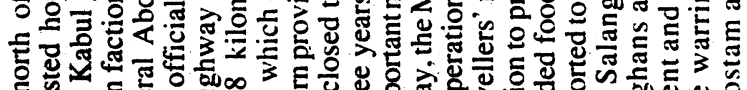

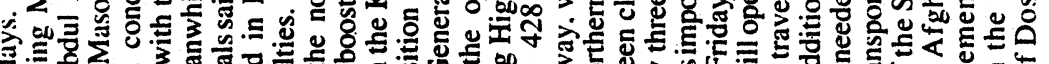

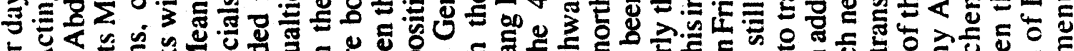

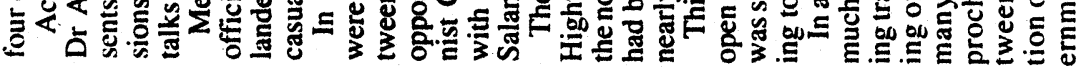

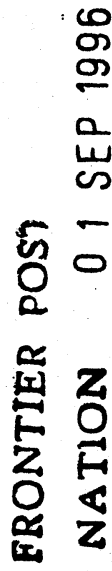

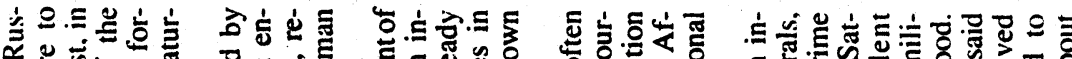

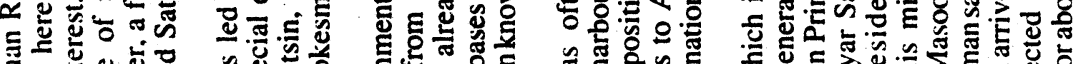

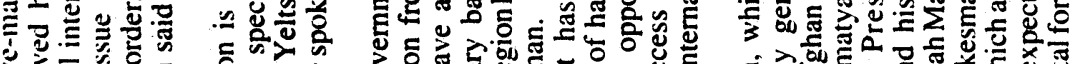

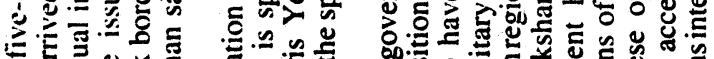

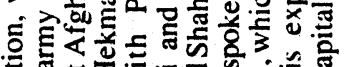

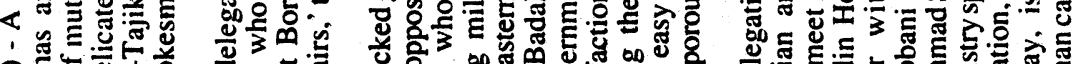

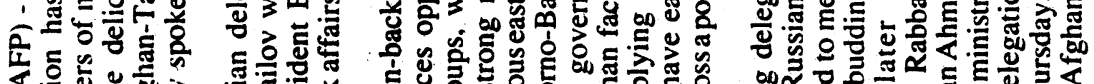

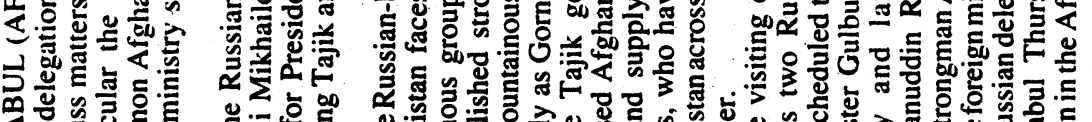

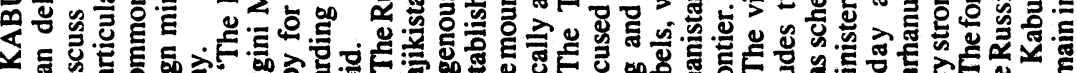

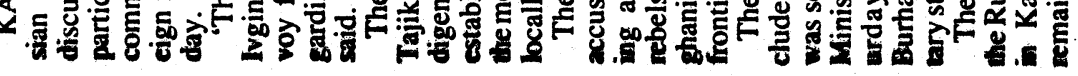

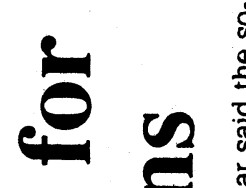

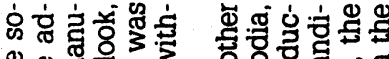

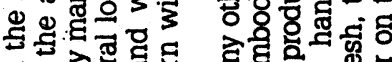

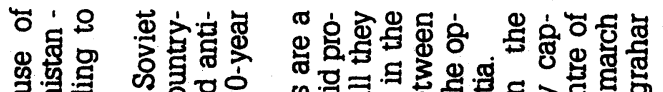

\%马्व

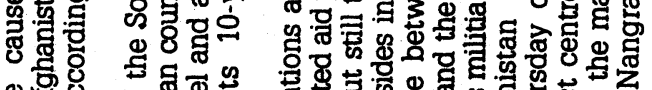

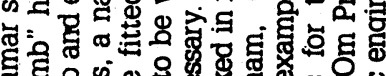

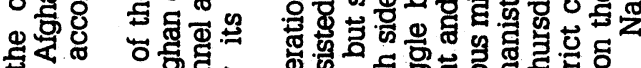

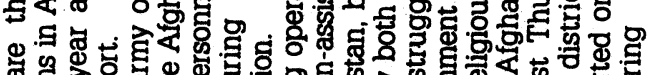

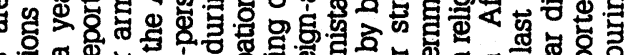

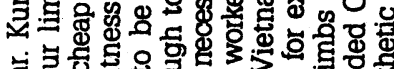

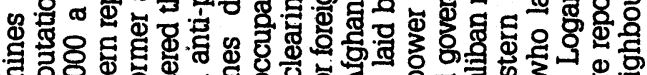

QD 0

2 1

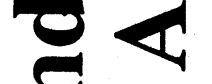

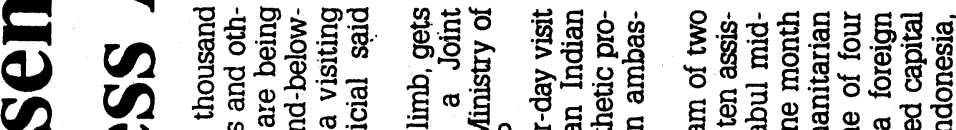

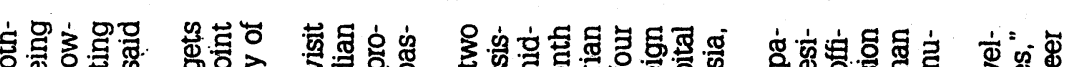

(2) 2 (1)

-10 a

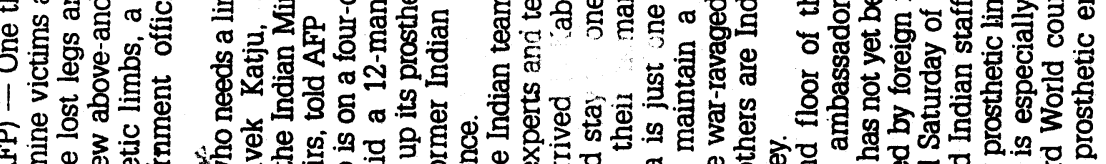

$\begin{array}{ll} & \\ 0 & \end{array}$

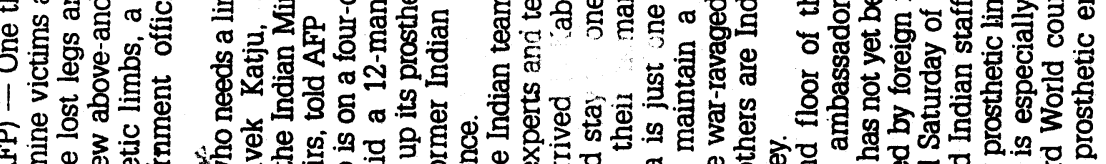

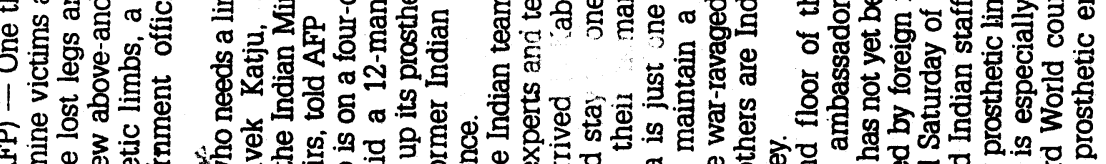

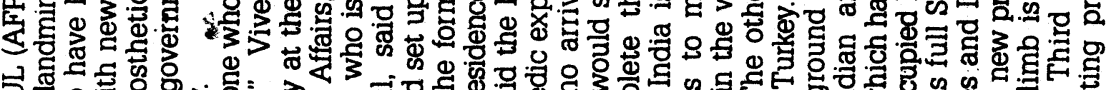

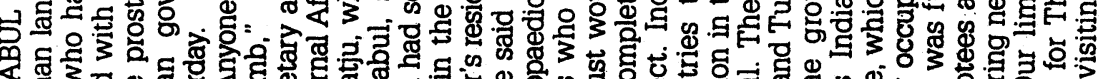

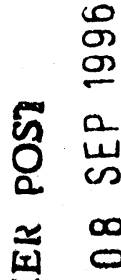

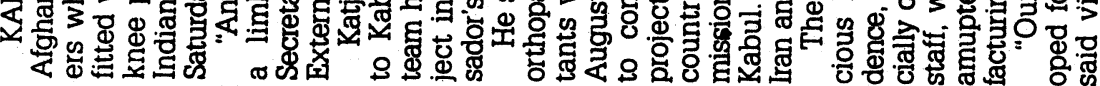

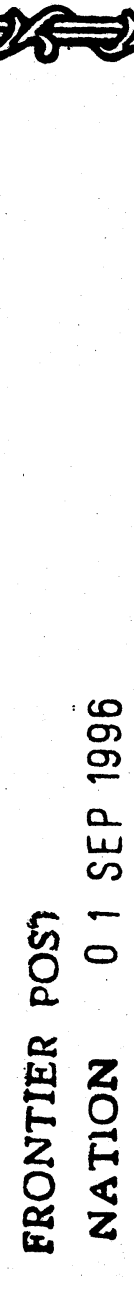




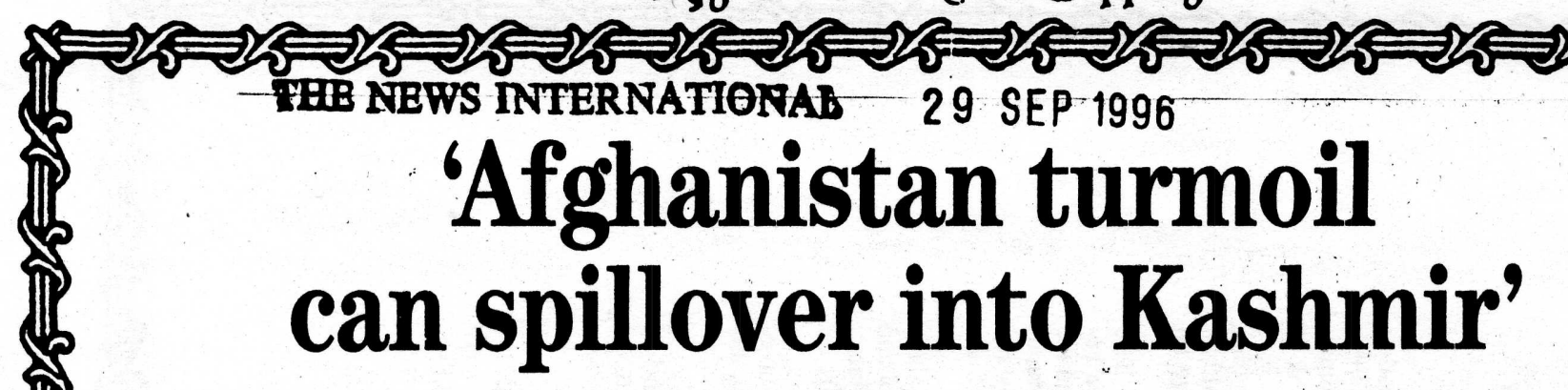

\section{'If Kabul's new rulers turn out to be remote-controlled by Islamabad, Russia, Iran and India have equal cause for concern'}

NEW DELHI: The Indian media on Saturday reacted with concern over the fall of the Afghan capital to the Islamic Taliban militia, fearing that the turmoil could spill over into Kashmir.

All of India's newspapers accused Pakistan of being behind the Taliban's success in taking Kabul on Friday and predicted that several countries in Central Asia would be troubled by the turn of events.

The Hindu daily's editorial said the fall of the capital could have "serious implications for regional powers including India, Pakistan, Iran, Central Asia and Russia.

If the Taliban consolidated its position, it predicted, "Pakistan will gain the most", adding: "Pakistani consolidation may leave an impact on two major insurgencies, of which Afghanistan lies at the hub." Afghanistan is widely believed to be the epicentre of the insurgencies in Kashmir and Tajikistan.

Pakistan's influence in an unstable Afghanistan can greatly encourage cross-border terrorism." The Pioneer, meanwhile warned that the Taliban, as Sunni fundamentalists, would "turn Afghanistan into a huge religious laboratory." The Taliban's execution of former communist Afghan president and Indian ally Najibullah was an example of "medieval justice," it said.

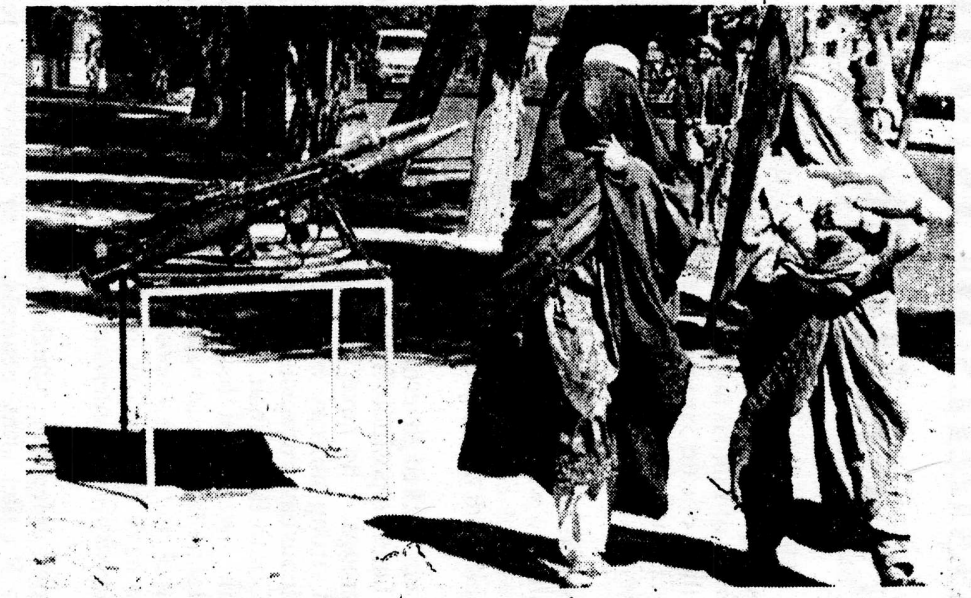

WOMEN AYD ISLAM:Two Afghan women dressed in the full traditional vell called the "chadari" pass by the weapons of Taliban militia in Kabul near the defence ministry. The women have to dress according to the ruling Ta/iban in Kabul, this is typical style of dress required by the Islamic militia. AFP wirephoto,

"They have the choice of directing their destructive energies towards Central Asia or even Kashmir." More than 15,000 people have died in Indian-controlled Kashmir since militant Muslim separatists there launched a campaign against Indian rule in 1989.

The Pioneer added: "If Kabul's new rulers turn out to be remote-controlled by Islamabad, Russia, Iran and India have equal cause for concern."
The Times of India said: "Despite its protestations, the Pakistani government's close involvement in the Taliban's rise to prominence has been an open secret." fall of Kabul to the Taliban' has brought Pakistan a step closer to the realisation of a dream, its grand design of establishing a pan-Islamic state in the region." -AFP
The Indian Express added: "The

\section{Security tightened in New Delhi}

NEW DELHI(AFP)-Police stepped up security here Friday for relatives of Afghanistan's former communist president Najibullah, executed after the fall of Kabul by the Taliban religious militia.

Officials and witnesses said armed commandos took position around the house where Najibullah's widow and two daughters have been living for the past five years.

Najibullah, installed by the former Soviet Union as president in 1989, was publicly hanged after the Taliban overran Kabul.

Securitymen prevented journalists and visitors from entering the house and blocked a street leading up to it, the witniesses said.

"We are taking special precautions because we feel the family could be put to harm by any of the many rival political factions from Afghanistan," a senior police official told AFP.

The Indian government granted asylum to Najibullah's family after a coalition of Afghan mujahedeen guerrillas took control of Kabul in June 1991.

Several close cabinet colleagues of the former communist leader, including former prime minister Fazle Haq Khaliqyar, are believed to be living in India.

An estimated 40,000 Afghan refugees, many from the communist era, have also been given permission under an United Nations programme to stay in India, which had close ties with Najibullah's Sovietbacked regime. 


\section{Afghan situation closely}

NEW DELHI, Sept 27: India on Friday closely monitored what it called an "extremely fluid situation" in Afghanistan and stepped up security at residences maintained in New Delhi by the families of two former Afghan presidents.

One of the ex-presidents, Najibullah, and his brother were executed by the Talibn militia after its forces swept into the ruined Afghan capital overnight and proclaimed the complete enforcement of Islam in the warwracked country.

The other former president, Babrak Karmal, was believed to be in Moscow.

Afghanistan's ambassador to India, Masood Khalili, told a news conference in New Delhi on Friday that the current president, Burhanuddin Rabbani, and members of his government were about $25 \mathrm{~km}$ north of Kabul.

He said Rabbani's government C) still controlled 13 of Afghanistan's 31 provinces.

Kabul's dramatic overnight collapse was the result of a considered decision by the Rabbani govern. ment not to endanger the lives of the city's 1.5 million civilian population, the ambassador added.

"Now they will decide how and when they should launch or enforce their military strategy against Talibn," Khalili said.

Najibullah's widow, meanwhile, was seen being driven off at speed in a bullet-proof car from her New Delhi residence to an undisclosed destination, apparently in the direction of Delhi's airport.

Indian troops had surrounded the sprawling Najibullah house in the exclusive Asian Games Village and some soldiers took up positions on rooftops near the Najibullah complex.

"We heard the news on television, it's shocking," Roman Baryalai, a nephew of Babrak Karmal, said in New Delhi of the Talibn takeover. "I am waiting for more news," he added.

He said he had not heard from his uncle, who was in Moscow.

An unknown number of wounded soldiers loyal to President Rabbani were being treated in several private hospitals in the Indian capital.
Meanwhile, the Indian government said it had evacuated its diplomats from Kabul just hours before the city fell to the Talebin militia.

Foreign Secretary Salman Haider told a news conference that 11 Indian officials left on the last flight from Bagram military airbase near Kabul on Thursday night.

"We are watching an extremely fluid situation which is very unclear," Haider added.

India joined President Rabbani in accusing Pakistan of interfering in Afghanistan's internal affairs. Reuter

\section{'Pakistan could burn its fingers in Afghanistan'}

NEW DELHI (AFP) - Pakistan will play a major role in Afghanistan if the Taliban Islamic movement consolidates power but Islamabad could burn its fingers in the long run, an Indian expert said on Friday.

Kalim Bahadur, head of Central Asian Studies at New Delhi's prestigious Jawaharlal Nehru University, claimed the Taliban, who he said were widely believed to be backed by Pakistan, had effectively taken over the country after capturing $\mathrm{Ka}$ bul on Friday.

"Taliban gain some sort of legitimacy because whoever controls $\mathrm{Ka}$ bul, controls the country," he said.

"Their success will mean that $\mathrm{Pa}$ kistan will have a major say in policies."

But he warned the turmoil in Afghanistan could rebound on Pakistan, with many rebels opposed to Benazir Bhutto's government now getting weapons from Afghanistan.

Bahadur said: "It could be disastrous ultimately. Pakistan has become a victim of many of the policies it adopted in Afghanistan under president Zia-ul-Haq.

"The illegal supply of Western arms to Afghans has backfired and is now being used by Pakistanis."

He added: "Drug addiction in $\mathrm{Pa}$ kistan has grown tremendously because of the illegal drug trade it supported in Afghanistan."

Bahadur said Islamabad's interference in Kabul would also exacerbate Pakistan's relations with Iran, since Tehran wanted a Shiite government instead of a Sunni leadership like the Taliban.

"Pakistan and Iran's interests in Afghanistan are at cróss-purposes," he said.
Pakistan has consistently denied being actively involved in Afghanistan.

Bahadur said the two-decade-old unrest in Afghanistan was basically tribal and unlikely to die out"The Taliban is basically a Sunni force comprising Pushtun tribals and they will usher in religious and ethnic unrest ... the struggle is mainly a tribal one, whatever the ideological surface.

"Most parties have tribal affiliations. The Talibans are Pushtuns, (President) Burhanuddin Rabbani and (Rabbani's military strongman) Ahmed Shah Masood are Tajiks, (former communist general) Abdul RashidDostam is Uzbek ... they have been fighting along these lines for centuries."

Multi-ethnic Afghanistan's 16 million people include large minority groups including Uzbeks, Hazaras, Tajiks and Ismaelis.

"There is a lot at stake because Afghanistan is the gateway to Central Asia," Bahadur said. "Purely for economic resaons, the Americans are interested, Pakistan is interested and Iran is interested."

Bahadur said the Russian stance would be muted because the breakup of the erstwhile Soviet Union had undermined Afghanistan's importance vis-a-vis Moscow.

"But there are Uzbek, Tajik and other. Central Asian agents provocateurs playing politics in Kabul ... Moscow is keeping a distance but will not tolerate undue Pakistani or American influence."

\section{NATION}

29 SEP 1996 


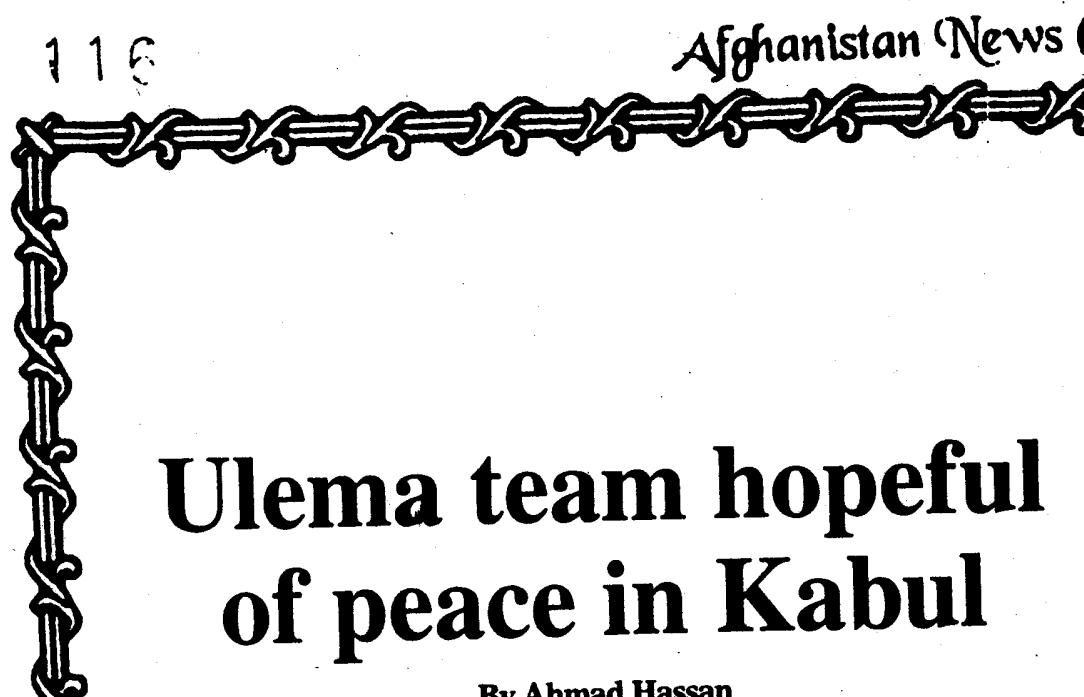

\section{By Ahmad Hassan}

PESHAWAR, Aug 31: A 50- member delegation of Pakistan Ulema, which returned here after a threeday visit to Kabul on Friday, has expressed its optimism about the prospects of a reconciliation between the two main warring parties - the Afghan government and the Taliban.

Speaking at a news conference here on Saturday, Maulana Abdur Rahman Ashrafi, director of Jamia Ashrafia, Lahore; and Maulana Rahat Gul, director of Darul Uloom , Rahatabad, Peshawar, who were members of the team, said that encouraged by a positive response to their initiative for a reconciliation, from Kabul rulers, including President Burhanuddin Rabbani, Prime Minister Gulbadin Hekmatyar, commander Ahmed Shah Masood and Prof Sayyaf, the Ulema had decided to hold talks with the Taliban within a week.

For this purpose, they said, preliminary contacts had been established and arrangements for their journey were to be finalised soon.

The visit of the delegation which comprised non-political and noncontroversial Ulema from all the four provinces, was sportsored by the Kabul government which had sent a plane to Jalalabad to take them to the Afghan capital and back.

Maulana Ashrafi and Maulana Gul said the delegation members had held meetings with all government leaders in Kabul and got a positive response to their initiative for a reconciliation. They said Hekmatyar had even offered a five-

point formula for a reconciliation, which was endorsed by all other leaders.

The formula envisaged an immediate ceasefire, creation of an atmosphere for dialogue, setting up of an interim government, removal of heavy arms from big cities of the country and enforcement of Shariat ,they said.

The Ulema said President Rabbani, during the meeting with the delegation, had even offered to step down if it was necessary for a reconciliation.

They further said that the Kabul regime had announced that it would accept the Ulema, compris ing the delegation, as mediators, who could take any step which was essential for ending the stalemate between the Taliban and the Kabul regime. They said the fears of the Taliban that the Kabul regime was not really interested in a reconciliation, were allayed by the high-ups with whom they had met in Kabul.

The Ulema said the conditions set by the Taliban for a dialogue and a subsequent reconciliation, included enforcement of Shariat, recovery of heavy arms (disarming of all groups ), removal of communist elements from key posts in the capital, were accepted by Kabul rulers during their talks and they had also agreed to go to any length for the establishment of peace and a true islamic order in the country.

The Ulema said that during their meeting the Kabul rulers had not accused Pakistan of helping the Taliban.
FRONTIER POST
DAWN
01 SEP

Najam to visit Kabul to reopen Pak mission

\author{
By our correspondent
}

ISLAMABAD: Foreign Secretary Najmuddin Shaikh is leading a Pak delegation to Kabul on September 19 (1) hold wide-ranging talks with Afghan officials.

"The secretary is expected to perform the opening ceremony of Pak Mission in a building provided by the Rabbani administration," according to a highly-placed source.

The decision to reopen Pakistan Embassy was taken in a recentlyheld meeting of the Afghan Cell, which met following the visit of an Afghan delegation to Islanabad.

"The foreign secretary will hold bilateral talks with the Kabul administration, besides taking up peace efforts, bilateral trade and foreign policy issues," said the source, who added that foreign secretary may also meet President Rabbani and Prime Minister Gulbaddin Hekmatyar and other key leaders and officials during his trip to Kabul.

"The visit will bring on track Islamabad-Kabul strategic relations, and it will be a milestone to re-establish brotherly relations with Afghanistan," said the source.

Pakistan is also sending another delegation to the Afghan capital for assessment of damages caused to its embassy last year.

Najamuddin to visit Afghanistan

\section{next week}

ISLAMABAD (PPI) - Foreign Secretary Najamuddin Sheikh, will visit Afghanistan next week to discuss with Afghan leaders matter relating to reopening of Pakistan Embassy in Kabul, official sources said on Saturday.

The Foreign Secretary will lead a six-member delegation and is likely to leave for Afghan capital on September 7.

It will be the first high-level Pakistanidelegation visit to Afghanistan since the destruction of Pakistan embassy in Kabul.

Afghan Interior Minister Younas Oanooni, who led an eight-member delegation to Pakistan in the second week of August, requested Pakistan to re-open its embassy in Kabul. The delegation had also expressed readiness to provide temporary accommodation to Pakistani diplomatic mission in Kabul.

Pakistan had agreed to send a team to Kabul to consider favourably the Afghan government prom(w) for reopening of its embassy in Kubul.

NATION 


\section{Rabbani govt offers three buildings for embassy}

By Shakdl Shalkh

ISLAMABAD: Pakistan's mission in Kabul is likely to start functioning within next few weeks, as Rabbani administration has offered three different buildings to Islamabad.

According to official sources, a high-level delegation will leave for the Afghan capital this week to choose one of the three buildings offered by Kabul. The Pakistani team will be headed by Foreign Secretary Najmuddin Shaikh and include other senior officials.

"The basic purpose for sending the delegation is to finally select a building for reopening of the mission, which was closed down last year following attacks and destruction of the building," said an official source.

According to the source, a decision to this effect, besides reviewing the overall Pak-Afghan relations, was taken in the recently-held 1 of the Afghan Cell, which was altended by all of its members.

Kabul, said a source, has also given an offer to help reconstruct the destroyed Pakistan Embassy building, and its restoration according to the desire of Islamabad.

"Our policy is to maintain evenhandedness with all the groups, without interfering in the internal wrangling in Afghanistan," said the source privy to the Afghan Cell consultations.

So much so, said an insider, Ahmed Shah Masood's behaviour has now been changed, in a positive way, towards strengthening relations with Pakistan.

"Things are moving in the right direction, as Rabbani administration has given signal to put Pak-Afghan relations back on track," said an official source.

\section{Pak delegations to visit Kabul soon: Aseff}

\section{By ShakJ Shalkh}

ISLAMABAD: Pakistan is sending two delegations to Kabul for talks with the officials of the Rabbani administration.

"Both delegations, one led by Foreign Secretary Najamuddin Shaikh and the other by the Foreign Office director general, will proceed to Kabul soon," Foreign Minister Sardar Aseff told The News on Wednesday, who returned to work after several weeks of medical treatment in Lahore.

Aseff said Shaikh's delegation will hold talks with Afghan officials on "wide range of issues" including bilateral relations, trade, transit and UN efforts for Afghan peace.

He said the second delegation led by the FO director general will visit Kabul mainly to assess the damage caused to the Pakistan Embassy. "We have nqestimates about the damage as we have not visited the site yet. The technical delegation will finalise the estimates for the repair and reconstruction of the building with a view to restoring its original shape."

He said the technical delegation will also include some engineers and technical people from other government departments.

Officials, meanwhile, said Najamuddin Shaikh will also inspect the buildings offered by the Rabbani government where Pakistan can setup its mission as long as the destroyed embassy is not re-constructed.

Pakistan, according to official sources, looks keen to normalise relations with Afghanistan as most of the irritants in Pak-Afghan ties have already been removed through talks held last month.

\section{Pakistan out to divide Afghanistan: JI}

MANSEHRA - Pakistan is interfering in the internal affairs of Afghanistan on the behest of the United States stoking bloodshed in the war-torn country, amir of the Jamaat-i-Islami Qazi Hussain Ahmed said here Saturday.

Qazi addressing a conference here said the triangle comprising Prime Minister Benazir Bhutto: Asif Ali Zardari and Interior Minister Nasirullah Babar, in collusion with the United States, was bent on dividing Afghanistan along linguistic lines.

He said, "We have no special relations with Burhanuddin Rabbani and Gulbaddin Hekmatyar and no enmity with Taliban", he said, adding the whole drama was being played by Pakistani rulers to safeguard the US interests.

Qazi said the Muslims of South East Asia were passing through an hour of trial and the focus of their struggle had taken three dimensions: to librate Kashmir; to bring peace to Afghanistan; and to 'liberate' the people of Pakistan from the clutches of feudal lords and corrupt bureaucracy.

He said the independence of Pakistan had brqught ino fruit to the masses who were still living below the poverty level. On the other hand, the rulers, feudal lords and industrialists were plundering the public money and sending it to foreign banks.

The Jamaat amir said every year Rs. 200 billion were being drawn from the public exchequer by the rulers and influentials as kickbacks in cilstent projects and illegal gratification.

\section{FRONTIER POSH}

\section{SEP 1996}

\section{THE NEWS INTERNATIONAL}


ISI.AMABAD Sept 12: The Forwin iffice said on Thursday there was no change in the scheduled visit of Foreign Secretary Najmuddin Sheikh to Kabul and other provincial capitals in Afghanistan from Sept 19 although Kabul had accused Pakistan on Tuesday of "hatching conspiracy" to assist Taliban to capture Jalalabad.

The foreign secretary's planned visit was to "clear the air" with the aim to arrive at an understanding and discuss with Kabul authorities the reopening of Pakistan embassy in the Afghan capital.

Pakistan had withdraw its entire mission personnel after a violent mob attack and arson at the Pakistan mission housed in former British embassy building.

Asked what measures Pakistan had adopted to ensure safety of the foreign secretary to Kabul in view of the new hostile situation arising from loss of Jalalabad, an important town on the highway from Pakistan's Torkhum town to Kabul, 's Torkhum town to Kabul, tries were in constant touch.-HA the spokesman said he could not spell out what measures Pakistan government had proposed to guard the foreign secretary but he hoped he would be protected fully.

The foreign secretary's visit was planned following the fence-mending visit by Kabul's interior minister and his delegation last month which also made government-togovernment arrangement for purchase of sugar, other food items and fuel which are in short supply in the Afghan capital. Kabul had also agreed to compensate for damage to the Pakistan mission in the Afghan capital and for the loss of life of a mission employee.

The spokesman said Pakistan had closed the highway between Torkhum and Jalalabad two days before Taliban's invasion of Jalalabad after receiving reports of increased cross-border movements. Answering newsmen's questions, he said, Pakistan had not made any contact with Iran following fall of Jalalabad but he said the two coun-

\section{Pakistan not helping any Afghan faction, says Clement}

FAISALABAD (Agencies) - Pakistan is not siding with any group or faction in Afghanistan, said George Clement, Federal Parliamentary Secretary for Foreign Affairs here on Monday.

Talking to a group of newsmen at his residence, he saidthat Pakistan wanted peace in Afghanistan as without tranquility in this neighbouring country, there could be difficulty in promoting cconomic relations with the Central Asian States.

He said that the present infighting in Afghanistan was the drive of various factions to prevail over each other.

"Pakistan is not concerned under which formula or agreement peace is restored in Afphanistan; it just wants peace", he clarified.

On Kashmir . Clement said that $\mathrm{Pa}$ - kistan would use the fora of the Organization of Islamic Conference (OIC), Group-77, Commonwealth and Non-Aligned Movement to muster support for the settling of Kashmir issue under UN resolutions.

"There is also need to highlight the damage inflicted to the environmenta conditions in the Kashmir valley due to the presence of 610,000 Indian troops", he added.

Onquestions on Comprehensive Test stan would make decision on the issues like ratification of the CTBT after taking into account all the national and that Pakistan had suggested that South Asia be declared as Nuclear Free Zone (NFZ) but India had not given any positive response to this proposal. Ban Treaty (CTBT) he said that Pakiregional security conditions. 1 He said
JI leader accuses PM of playing dangerous game in Afghanistan

Buroeu Ropert

PESHAWAR: Jamaat-i-Islami provincial chief Prof Mohammad Ibrahim on Thursday accused Prime Minister Benazir Bhutto and Interior Minister Naseerullah Babar of playing a dangerous game in Afghanistan just to please the United States.

In a statement, he said the leaders of Jalalabad were evacuated by Pakistan to create a vacuum. He also accused Pakistan of sending Taliban from Torkham. He deplored that the game was being played to keep the flames of war burning in the neighbouring country.

The Jamaat leader demanded of the PPP government to stop the bloody game in Afghanistan and keep Pakistan's interest in mind instead of America's. He also asked the Taliban to come to the negotiating table for solution of the problem.

\section{Pakistan rejects Kabul's allegations}

ISLAMABAD: Pakistan Wednesday strongly rejected allegations from Kabul that it had interfered in Afghanistan or that Taliban had moved to Jalalabad from Turkham.

A Foreign Office spokesman said that according to the information reaching Pakistan, the Taliban had moved to Jalalabad from Hasarak and had occupied Jalalabad without resistance.

The spokesman regretted that unfounded allegations levelled by Kabul with which Pakistan had been seeking to normalize its relations and it had also received a delegation in this connection from Kabul led by its Interior Minister Ganooni last month.

Pakistan he said was making every effort to promote an intraAfghan dialogue which could bring durable peace to Afghanistan and for this purpose it was trying to maintain contact with all Afghan factions.

The spokesinan recalled that the foreign secretary of Pakistan was scheduled to visit Kabul and thereafter to other provincial capitals of Afghanistan from the 19th of this month to promote this objective.

Referring to the personnel of $Z$ Pakistan consulate general in Jalalabad, the spokesman said that they have been evacuated to $\&$ Pakistan and they are safe.-APP

$$
\text { NATION } 17 \text { SEP } 1996
$$




\section{Taliban has US backing: Beg \\ JUI terms Rabbani

\section{Indian agent}

From TARIQ ZFESHAN

ABBOTTABAD - Chief of the Pakistan Awami Qiadat (PAQ) party Mirza Aslam Beg Wednesday did not ruled out the possibility of Taliban having US backing to break Iranian influence over the Afghan government and thwart formation of an Islamic bloc.

Beg also attributed the success of Taliban to the factional fighting in Afghanistan and the prevailing frustration among ordinary Afghans.

He, addressing a press conference here, said there was no solid evidence to prove that Pakistan was backing Taliban.

Beg said the people of Afghanistan were fed up with civil war; that's why Taliban faced no resistence in capturing several provinces.

like Afghanistan, the people of Pakistan are also disgusted with both the major political parties, as well as the smaller ones, the former COAS said, adding over 80 per cent people would vote for military rule if asked in a referendum.

Beg claimed that he had come into politics only to instill confidence in the people and fight for provision of justice, honour and dignity to commonman.

He said the government of Prime Minister Benazir Bhutto would complete its five-year term as the United States had no other option except Bhutto.

General elections will be held in 1998 and the change would be a democratic one; there would be no role for the proposed agenda of Nawaz Sharif, Qazi Hussain Ahmed and Imran Khan, Beg added.

He said army had several reasons to intervene but it would resist such temptations because its interference in political affairs was decreasing with time. "Army's intervention and dictatorial erd is over", he added. He also favoured a constitutional role for army.

Beg claimed that the US intelligence agency CIA had the biggest base in Islamabad to keep an eye on Iran, China, Afghanistan and Central Asia. He stressed the need for decreasing US influence in the country.

Regarding the Comprehensive Test Ban Treaty (CTBT), the former army chief said Pakistan's stand was a diplomatic achievement of the government. and independence

of Afghanistan.

The PMAP while warning Pakistan asked the government to stop alleged interferences in the internal affairs of Afghanistan

HUNGER STRIKE: Fifteen members of different government employees association observed token hunger strike here on Sunday for the restoration of unattractive area allowance for Kalat division employees.

The hunger strike camp was established in the front of Balochistan assembly building and the protestors observed the token strike from the morning till evening.

The representatives of political groups and labour unions visited the hunger camp and assured the employees of their cooperation.

\section{By Our Correspondent}

SUKKUR, Sept 14: The secretary-general of Jamiat Ulema-eIslam (F), Sindh, Dr Khalid Mehmood Soomro, has called the Afghanistan President, Burhanuddin Rabbani, and his colleagues Ahmed Shah Masood and Prof. Sayyaf as Indian agents, and added that the more they remained in power the greater damage they would cause to solidarity of Pakistan.

Speaking at a Press conference at Madressah Manzil Gah on Saturday, the JUI leader said his party supported the Taliban, most of whom were imparted religious education by JUI Ulemas.

He said Taliban were true Muslims as well as well wishers of Pakistan, while he dubbed Rabbani as anti Pakistan.

\section{DAWN}

\section{SEP 1996}




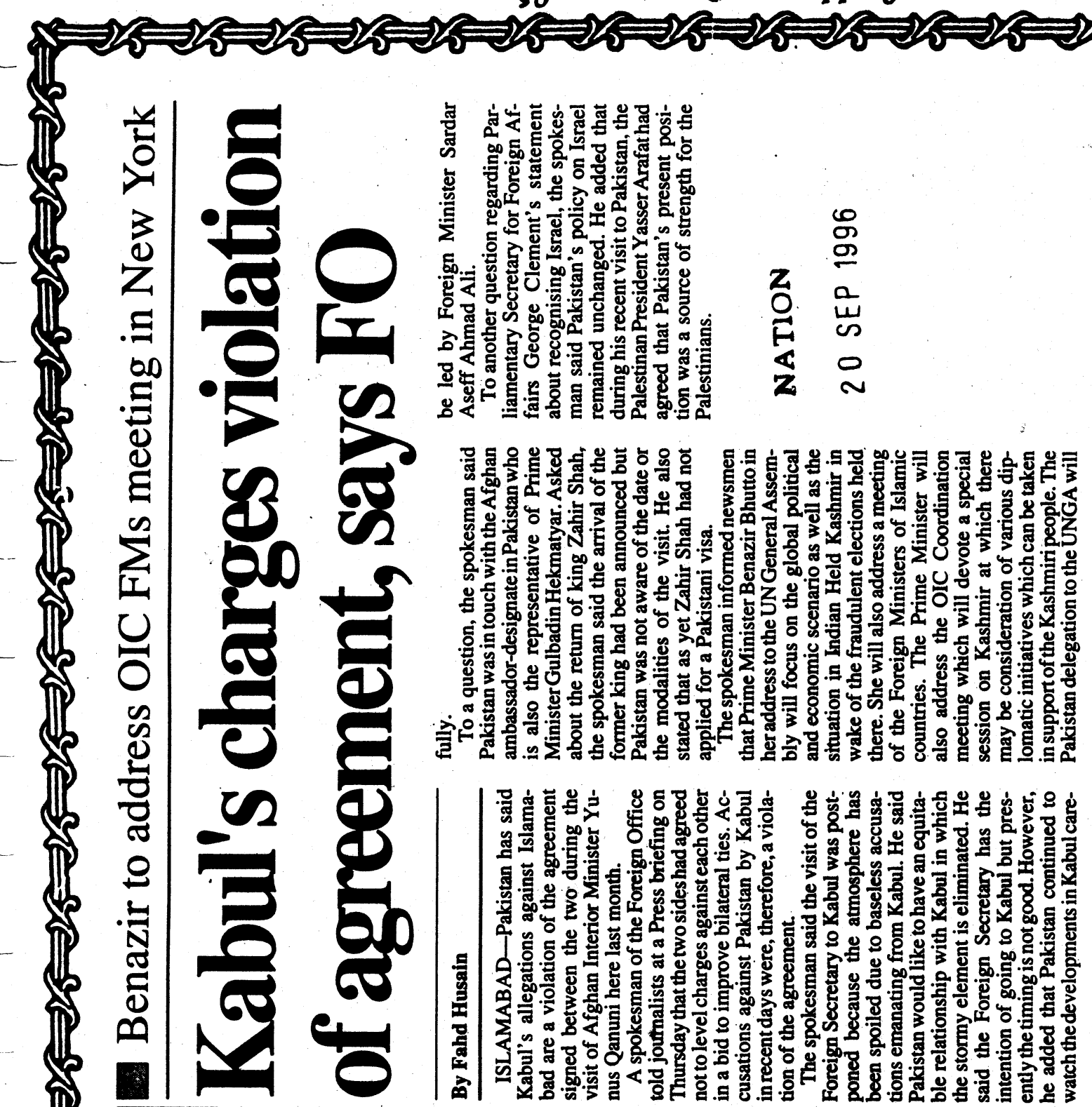

\%

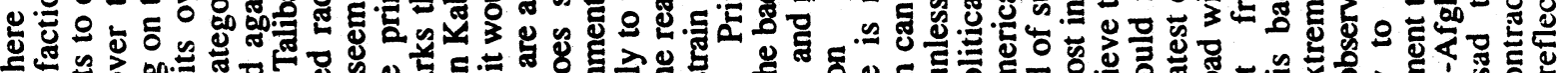

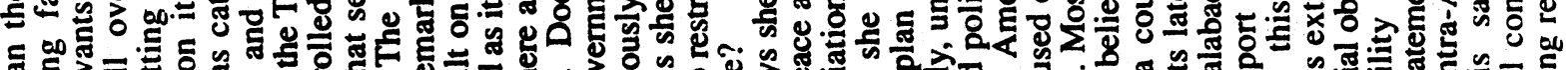

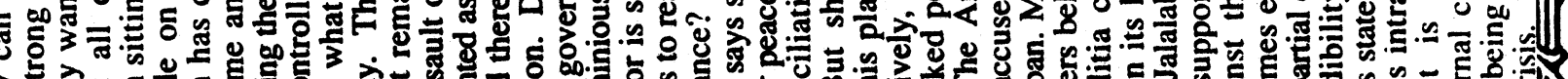
3

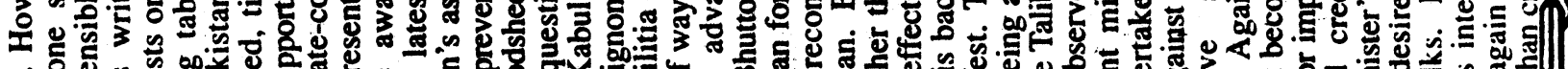
o

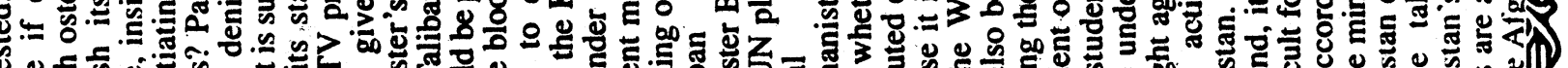

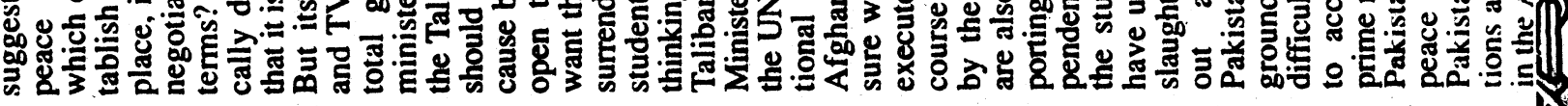

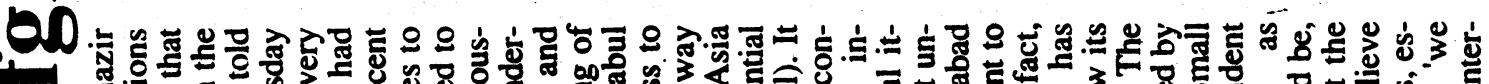

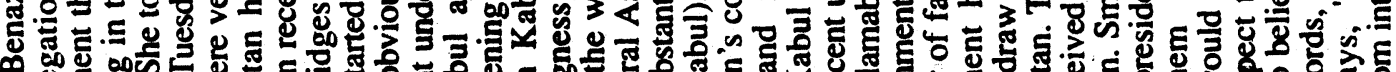

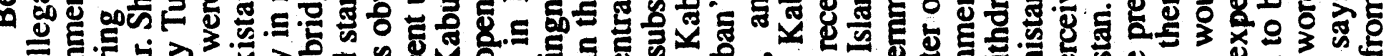
市 0 兽.

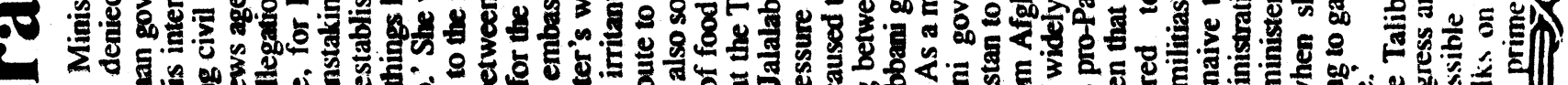

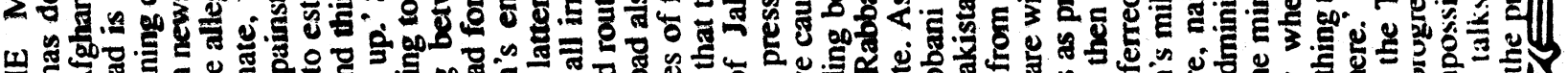

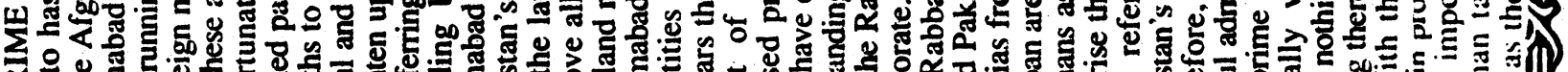

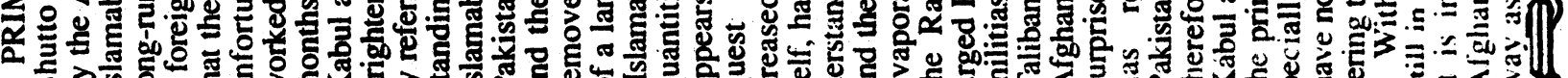

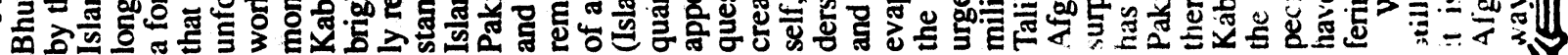
9661 d 356 LSOd UaILNU4A 
Heddigg very, misorablo lif as first the Britishers and then Punjabi imperialists hatched conspiracios to keep them (Pakhtoons) backwards", the Pakhtoon nationalist leader added.

He said that Pakistan was interferring in the internal affairs of Afghanistan. "Millions of Alghans were killed in the war which was imposed by the foreign powers on thom", he cald the putblia mooting.

Bacha said that the country's oconomy was in shamble and that Was dye to the-wrong policies of nulers. Ho wont an to eay that the rulars were busy in boting tho public money and wore giving very little attention' to the solution of problems being faced by 4 o people.

He charged that Pakhtoons were denied due righte as thoy weip not boing given stion in at. mobt all field. This is the right time for Pakhtoons to creete unity among themsolves as withour oro ating unity among thoir reanks ootting rights are inposedib", he idded.

The meeting through a rocoly. tion expressed congern over tha pollicothigh handedus with the resiftents of Naral Wals as it arleged the poor villegois were forcibly ejected from their houses. The meeting demended to stop this illegal act forthwith otherwise the PMAP would launch a movement against this move.

The meeting through another resolution demanded of the government to grant interest free loans to the farmers as the recent hike in the prices of fertiliser made it impossible for them to purchase it.

\section{Closure of Pak consulate in Jalalabad causing problems}

\section{From Our Correspondent}

PESHAWAR - Closure of Pakistan's Consulate General in the border town of Jalalabad caused problems for those war-affected Afghans who want to save themselves from the situation and arrived in NWFP. Pakistan's Consulate General at Jalalabad stopped functioning on September II last when the city fell to Taliban and foreign office at Islamabad has yet to announce a date for its opening.

This was learnt during a visit to Torkham which is jampacked by thousands of Afghans, mostly women and childrens who were forced to leave their homes in the fresh round of fighting.

In Nasar Bagh the Afghan Refu- gees Commissionerate opened a new camp for the war-displaced Afghans. So far, the authoritiescounted, around 800 Afghan families crossed the border and entered the province.

But majority of them adjusted themselves in the house of their nears and dears, already residing at Peshawar and other parts of the province. Only ten families, who arrived in Peshawar for the first time, reached the newly established camp at Nasar Bagh and received tents and plastic sheets.

At Torkham, this correspondent witnessed around two thousand people awaiting for the opening of the gate. But majority of them lack valid documents to enter Pakistan, therefore, the authorities concerned did not give them permission.

\section{NATION 22 SEP 1996}




\section{carrying Pakistani officials?}

\section{From Rahimullah Yusufzal}

PESHAWAR: Was the Taliban military transport plane which defected to Kabul Tuesday flying to Peshawar rather than Jalalabad or Kandahar and were the seven Pakistanis on board really military officials as claimed by the Rabbani government?

These two questions were agitating the minds of all those who heard the news Tuesday. Pakistan government officials too were baffled by the happening. The incident gave one more twist to the dramatic events unfolding in Afghanistan.

Enquiries made by this correspondent revealed that it was a Russian-built Antonov-32 military transport aircraft which took off from Herat with seven Pakistanis and 32 Afghans, apparently Taliban. The destination of the plane was either Kandahar,' which is headquarters of the Taliban Islamic movement, or Jalalabad which fell to them recently. But the defecting Afghan pilot landed the plane at Bagram, an airbase north of Kabul which serves as a lifeline for the Rabbani govt. Official sources said no Afghan military aircraft has flown from Herat to Peshawar since September 1995 when former governor Ismail Khan was defeated by the Taliban. They said presently Afghan military planes only from Mazar-iSharif fly to Pakistan. They maintained that no military clearance was obtained for this particular plane flying out of Herat Tuesday as was the standard requirement for all such flights. Moreover, they claimed not a single Taliban military aircraft has Hown to any airport in Pakistan since their emergence on Afghanistan's political horizon two years ago.

The claim by Kabul that seven Pakistani military officials were on board when the cargo plane landed at Bagram was dismissed by official cir- cles as baseless. Details about the identity of the seven men were awaited to find out more about them.

Enquiries showed that no member of the Pakistani consulate in Herat was on the flight. The consul general, commonly known as Col Imam, was away in Kandahar Tuesday. In fact, the consulate staff are required to fly only by UN and ICRC flights for security and safety reasons in Afghanistan.

Then who were the seven Pakistanis who took the fateful flight and are presently in custody of Kabul regime. Official sources said they could be traders who often travel to Afghanistan, Iran and the UAE to oversee their business of importing new and reconditioned vehicles and other foreign-manufactured goods from Dubai and transporting them via Iran and Afghanistan to Pakistan. They said the arrested Pakistanis could also be hunters who throng Afghanistan during this season to hunt for falcons, houbara bustard and other precious birds.

The incident is definitely going to further strain relations between Islamabad and Kabul. Any hopes of improved ties, nurtured during recent bilateral talks, were dashed to the ground recently when foreign secretary Najmuddin Shaikh's visit to Kabul was postponed due to a propaganda campaign by Rabbani government that Pakistan was assisting the Taliban. The two sides had earlier agreed to cease propaganda against each other and Pakistani officials felt Kabul violated it by accusing Islamabad of militarily helping Taliban to achieve their recent victories in eastern Afghanistan. The incident is a major setback for the Taliban as it is the second time in three months that their pilot has defected to Kabul. It was in July that a pilot defected to Kabul by flying his MiG-21 jet-fighter. from Kandahar to Bagram. THE NEWS INTERNATIONAL 25 SEP 1996

\section{presence in} Afghanistan

ISLAMABAD (AFP)

Pakistan on Tuesday flatly denied a Kabul government claim about that its military personnel are present in war-torn Afghanistan.

"There are no military personnel engaged in fighting anywhere in Afghanistan," a foreign office spokesman told AFP.

"This is absolutely untrue," the foreign office spokesman said rejecting the charges.

The dismissal of Kabul's claim came hours after the Afghan government announced that a transport aircraft of the rival Taliban militia had defected to Kabul with seven Pakistani military officers and 32 Taliban fighters aboard.

It said the plane, an Antanov AN-32, was flying from the Taliban-held western city of Herat to the Pakistani border city of Peshawar when its crew defected to Bagram airbase near Kabul without the knowledge of its passengers.

A Taliban official in Peshawar confirmed the plane had defected, denied the presence of any Pakistanis on board the aircraft.

The official said the plane was on domestic flight from Herat to the Taliban headquarters in the southwestern city of Kandahar and was not bound for Peshawar as Kabul officals have claimed.

"Perhaps this is ... hard evidence which suggests the obvious Pakistani interference in Afghanistan," an official statement said after the defection. It did not give the identity or ranks of the alleged Pakistani officers.

Defence Ministry sources here said "we have no information" about. the incident.

"The Taliban have never had any serious military fight" in their recent territorial gains, an official said

FRONTIER POST 


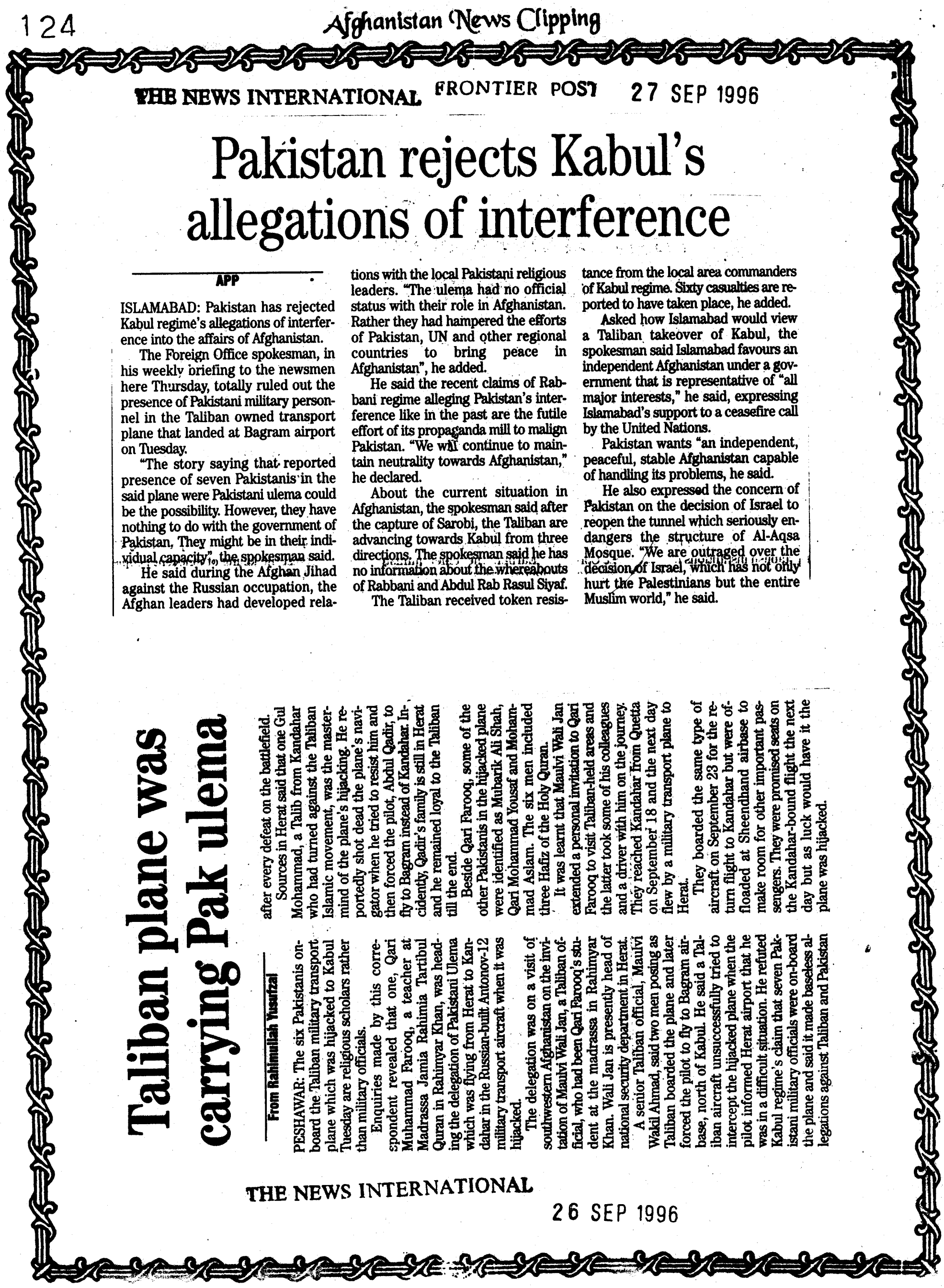




\section{BA offers fateha for Najib, JUI (F) walks out From AMANULLAH}

QUETTA - Balochistan Assembly members, both treasury and opposition benches offered fateha for late ex-president of Afghanistan Dr Najibullah while three members of JUI-F stated walkout from the House on a protest against fateha. Arjundas Bugti (JWP) deputy speaker presided the session here Sunday.

Dr Abdul Malik Baloch (BNMHayee) minister for health suggested that fateha be offered for Dr Najibullah, Mir Murtaza Bhutto and for the victims of Multan incident but JUI's members Maulana Abdul Bari and Maulana Abdul Wasay strongly opposed fateha for Dr Najibullah alleging that late ex-Afghan president was murderer of Afghans and termed as 'Kafir'.

The remarks of JUI members enraged PMAP ministers Hamid Khan Achakzai and Obaidullah who immediately act only made counter allegations against Jamiat leadership but also claimed that Dr Najibullah was a true Muslim. PMAP members accused JUI-F of working as agents of ISI.

Maulana Bari denied the allegations and blamed PMAP for receiving weapons and money from the late Afghan leader during his tenure as head of the state.

The speaker said that the issue should not be made controversial or politicized and proposed that it should be placed before the House for vote. When the issue was put to vote the members including Chief Minister Nawab Zulfiqar Ali Magsi supported to offer fateha, while JUI members staged walkout from the session.

Speaker ruled out four adjournment motions of JWP and JUI members.

\section{FRONTIER POST}

30 SEP 1996

\section{Pakistan sending team for talks with Taliban}

\section{By Marlana Baabar}

ISLAMABAD: Pakistan will send immediately a delegation to establish contact with the new government in Kabul and maintain its contacts with the Taliban Shoora in Kandahar, a foreign office spokesman said here Friday.

"The Taliban takeover in Kabul has now created a qualitatively new situation," the spokesman added.

The foreign secretary, Najmuddin Sheikh, while talking to The News, said, "We have always recognised the territorial integrity and sovereignty of Afghanistan and we have dealt with and recognised all the former governments and we will continue to do so in the futuren.

About the proposed Pak delegation to Kabul, Sheikh said, "I cannot tell you the exact date as events are moving very quickly in Afghanistan".

The foreign secretary, while condemning the hanging of Najibullah and his brother, said, "This is highly regrettable and I am trying to find out whether it was a local action or not. This is certainly not in accordance with the announcement of the Taliban in which they had declared amnesty. We are also sorry that the UN was not

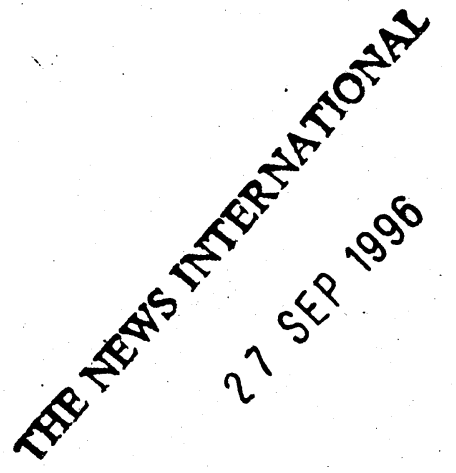

allowed to take out Najibullah earlier".

The foreign office on Friday set up a monitoring cell on Afghanistan andofficials were working round the clock reaching out to their contacts inside the besieged country and with their missions abroad. "So far we have had no contact with Abdul Rashid Dostam but I am expecting a report from our consul general late at night", the foreign secretary remarked.

The foreign office spokesman said Pakistan was informed, through New York, that Najibullah had been taken out of the UN compound shortly after the Taliban took over. An appeal for his safety by the UN was immediately conveyed to the Taliban Shoora in Kandahar by the government of Pakistan through its consulate general which added its own strong endorsement for protecting Najib. "At that time we were informed that the Shoora was onlyatrane of Najibullah's 80.0. the cholkesman said.

The Isolcerpon firther wid, The first priorifi will be to impress uion the new government the need for restraint and for the maintenance of conditions for the unimpeded flow of humanitarian assistance to the population of Kabul. It will also urge the need for such dialogue as may promote peace in all areas of Afghanistan."

Meanwhile, the former ambassador-designate to Pakistan, $\mathrm{Dr} \mathrm{Ba}-$ heer Ghariet, told The News that "Hekmatyar telephoned me in the morning and confirmed that he, Rabbani, Masood and Sayyaf are all safe but I am not at liberty to disclose their whereabouts." When told about the Kabul's directive that all Afghan ambassadors stood dismissed, Dr Baheer said, "The communique is not legal as the Taliban have still not formed a government. But I do not care about ambassadorial assignments." 


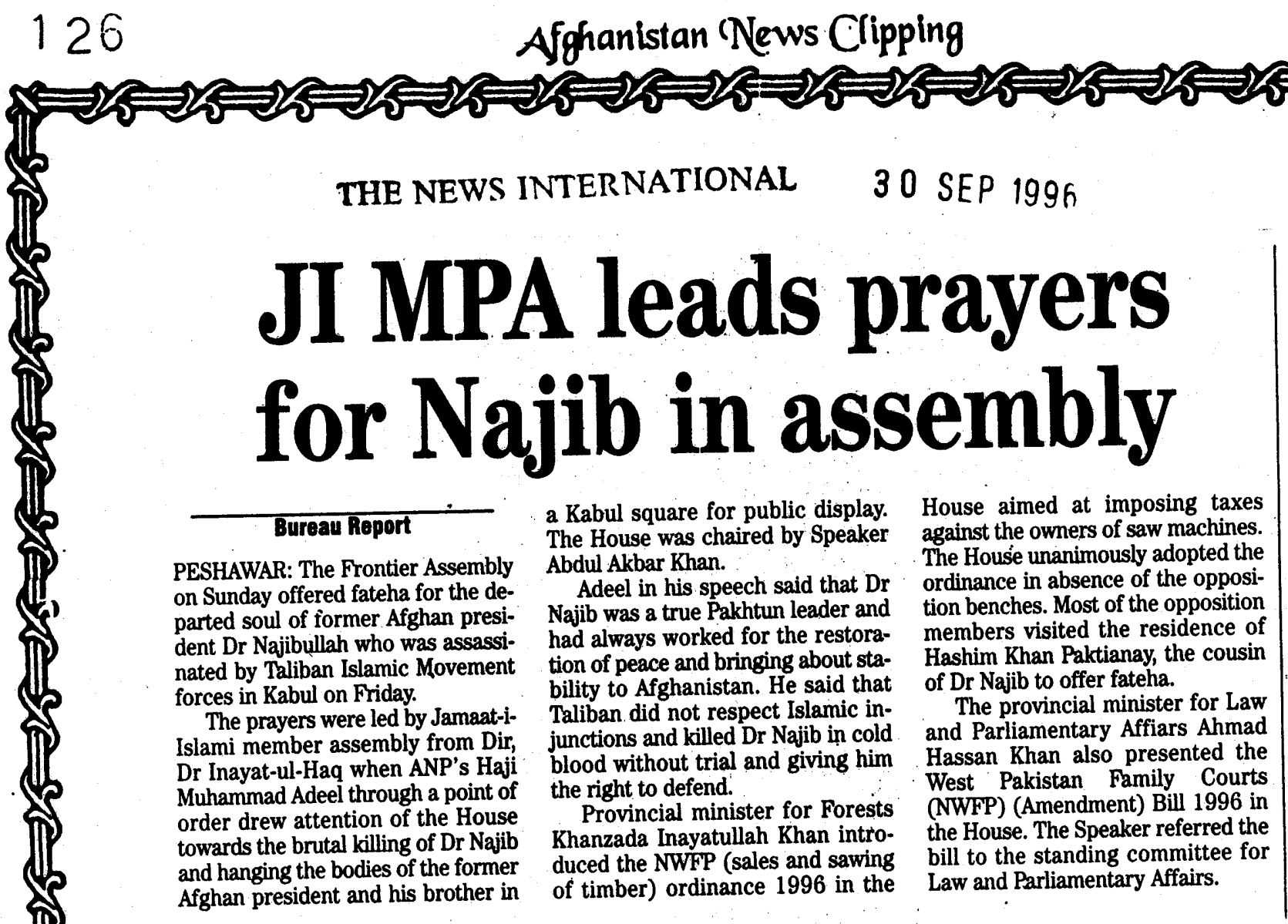

\section{Pakistan team in Kabul for talks}

ISLAMABAD, Sept 29: Pakistan has sent an official delegation to Afghanistan to meet the Taliban leadership to exchange views about the latest situation.

Foreign minister Sardar Aseff Ahmed Ali said here on Sunday that the delegation headed by a director-general of ministry of foreign affairs is currently holding negotiations with Taliban leadership in Kabul.

He said Pakistan was closely watching the developments in Afghanistan specially after the take over of Kabul by the Taliban and is following the reported advance of Taliban in Parwan and Jabulus Siraj.

Pakistan, the foreign minister said, had been doing business with every government in Kabul from Taraki to Rabbani and therefore, saw no reasons to depart from this practice.

"In any case, the question of legitimacy in Afghanistan is not for Pakistan to decide. It is for the Afghan leadership and Afghan people to decide what sort of government they need to have and how to run their own systems."

Referring to the recognition of newly-formed government in
Kabul, the foreign minister said historically, Pakistan has always recognised the Kabul regime as defacto government of Afghanistan and have extended friendship and cooperation to the government in Kabul.

"Pakistan was encouraged by the statement from the Taliban that they had nothing against General Dostum and would like to have good relations with him. This was a positive development for peace and stability in Afghanistan," the foreign minister added.

Sardar Aseff said during his last visit to Afghanistan he had detailed discussions with the Taliban leadership in Kandhar. Most of the Taliban leaders were personally known to him.

"The Taliban leadership were men of piety and had great love for Islam. They remembered with gratitude the sacrifices made by the people of Pakistan during the Afghan Jehad."

The foreign minister expressed hope that peace would now return to Afghanistan and the Taliban would be able to provide honest and clean administration as they had done elsewhere in Afghanistan. -APP 
UNDATED: The capture of the Afghan capital by the Taliban spread waves of apprehension across the region Friday, while Western capitals expressed particular regret over the summary hanging of former communist president Najibullah.

Russia voiced "alarm" at the development, while India said it would adopt a wait-and-see attitude, despite its mistrust of what it sees as Pakistani "interference" in the region and its concern that Islamabad might now turn its attentions to Kashmir. Iran described the new situation in Afghanistan as a "disaster." The United States called on the Taliban militia to work with other groups but deplored the execution of Najibullah, as did France.

Britain voiced concern over continued fighting in Afghanistan but withheld comment on the death of Najibullah.

INDIA: Indian foreign secretary Salman Haider said New Delhi would wait for a clearer picture to emerge in Afghanistan before taking a position.

In the meantime "we are taking stock of an extremely fluid evolving situation." Before reacting, "we have to see what shape Afghanistan takes," Haider said

Asked about alleged Pakistani backing for the Taliban, Haider said: "Our position on this is well known and has been made clear on many occasions. A settled Afghanistan provides potential access to the Central Asian republics but that is a theoretical possibility."

A foreign ministry official said: "Pakistan will now have more time to destabilise Kashmir because they don't have to work on the Afghan front."

IRAN: Iranian President Ali Akbar Hashemi Rafsanjani voiced deep regret at the continued fighting in Afghanistan, though he made no mention of the fall of Kabul. "We have re- peatedly advised the Afghans that war is not the right way to solve their problems but unfortunately they don't let go," he said. "The situation in Afghanistan has turned into a complicated and unsolvable issue in the region, and we will, for years to come, witness the homelessness and misery of the people there," he added. "This is a disaster and we strongly regret it."

UNITED STATES: In Washington, an official said the White House called on the Taliban militia to "move quickly to form a representative interim government" that would include other factions.

Deploring the death of Najibullah, he said it was "unfortunate that things had to start out this way" and called on Taliban "to respect the rights of all Afghans."

RUSSIA: Moscow, which provided military support for Najibullah's contmunist regime during the late 1980 s, said it "notes with alarm the danger that this conflict poses to the international community and its destabilising effect on the situation in the region."

The Taliban victory, the foreign ministry said, "aggravates the crisis into which Afghanistan has been plunged through internal armed conflict."

Moscow called for a ceasefire and a halt to all outside interference in Afghanistan and urged the UN "to face up to the Afghan conflict and play an effective role as a key impartial mediator."

UN: The United Nations in Geneva described the abduction of Najibullah from a UN compound in Kabul and his subsequent killing as a violation of international law that would jeopardise further efforts to bring peace to the region. A spokesman for the UN Special Mission for Afghanistan, Norbert Holl, in Islamabad, said, the killing of Najibullah would jeopardise "all the efforts which are being made to secure a peaceful settlement of the conflict.

THE NEWS INTER NATIONAL

28 SEP 1996 


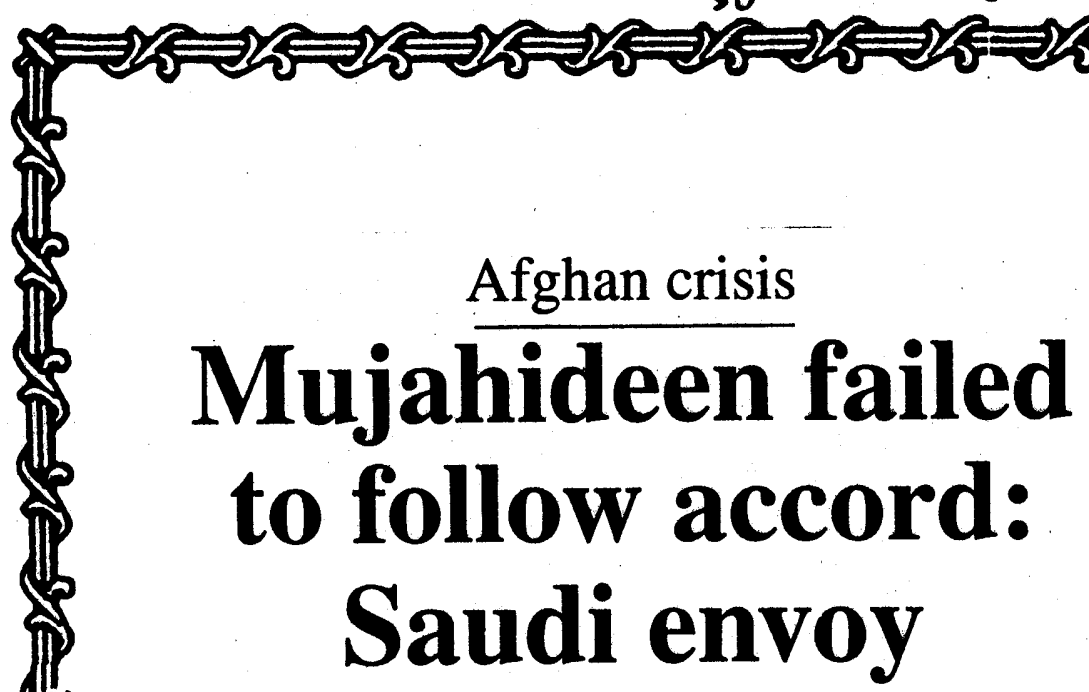

ISLAMABAD, Sept 22: The situation in Afghanistan could have been averted if the Mujahideen leaders had kept up their pledges of the reconciliation agreement signed in Makkah Mukarrama.

The views were expressed by the Charge d'Affairs of Saudi Arabia, Ismail Abbas Ayaz, in a message on the national day of the Kingdom.

He said the agreement signed between nine parties was signed with their mutual consent and was made without any outside interference.

Had the Afghan leaders complied with Allah's command: "And keep your promises surely it will be. inquired into," the tragedies endured by the Afghan people could have been avoided.

The Saudi government, he said, stood by their Afghan brethren in the Jihad since its inception. The Saudi government coordinated its stances and assistance with Pakistan and provided them support without any ulterior motives.

The Jihad, he said, was not confined to material support but extended to sacrifice of life when people voluntarily joined the armed struggle.

It was with this background that King Fahd Bind Abdul Aziz tried to remove the causes of the disputes and made efforts to repair the rifts among the Afghan groups and to unite them.

Referring to the relations between Pakistan and Saudi Arabia, he said, they enjoy strong relations in the Islamic, economic and educational fields and continue to witness several positive developments. These distinguished relations are built on judicious basis and common interests.

The leadership of both the countries, he said, had contributed by

building bridges of mutual cooperation covering various aspects of political, economic and technical activities.

He said varióus Saudi sectors were active in the field of development and loan funds. The joint Saudi-Pakistan commission is working to give an impetus to this cooperation and to extend its scope.

The Saudi Development Fund offered loans amounting to 905.44 million Saudi Riyals for building electrical stations, dams, roads, drainage and irrigation projects.

The Saudi private sector has participated with the amount of 1,000 million dollars in a project in Balochistan to set up the Hub power station.

The volume of trade between Saudi Arabia and Pakistan amounted to 674.4 million US dollars in 1994-95.

The Saudi Charge d' Affairs also highlighted its foreign policy, which, he said, was based on an effort to seek peace and security for the entire world, emphasising respect and sovereignty of each state, and non-interference in internal affairs of others.

He said the Kingdom, under the leadership of Khadim Al-Haramain Al-Sharifain, follows with keen concern the international and Islamic issues on the basis of firm policy of consolidating international peace and security.

Saudi Arabia, he said, had devoted its attention and given its support to the Arab and Islamic causes including Palestine, BosniaHerzegovina, Kashmir, Eritrea, Somalia, Afghanistan and Lebanon.

The Saudi ambassador also highlighted the pace of development in different fields in his country.APP

\section{Turkey concerned at Afghan conflict}

ANKARA (PR) - The ministry of foreign affairs of the Republic of Turkey on Afghanistan in a message stated that, "the government of Republic of Turkey follows the situation in Afghanistan with great concern and expresses its deep regret over the state of conflict getting more severe and gaining new dimensions.

"Turkish government believes that the civil war which led to the suffering of brotherly Afghan people for years can be terminated through direct negotiations among the conflicting parties and that a lasting peace in Afghanistan can be brought about by the establishment of a broad based government encompassing all parties.

"In this regard, the Turkish government would like to see the conflicting parties reach a ceasefire without any further delay and start negotiations under the auspices of the United Nations.

"For the achievement of this end, Turkey expresses its readiness to host with pleasure a meeting initiated by the United Nations".

\section{AI asks militia to respect human rights}

NEW DELHI (AFP) - The Indian chapter of Amnesty International Saturday urged the victorious Taliban to respect human rights in Afghanistan and flayed the militia for executing former president Najibullah in Kabul.

'The capture of Kabul by the Taliban armed group should not lead to further revenge killings, arbitrary punishments or other cruel, inhuman ordegrading treatment,' the regional unit of the London-based human rights group said.

The organisation also appealed to regional governments and the international community to pressure the warring factions in Afghanistan to ensure that human rights were respected during the Taliban's regime.

S.S. Nehra, president of Amnesty's local chapter, criticised the Islamic militia for allegedly torturing and hanging Najibullah, deposed by a coalition of mujahedeen resistance groups in 1992.

\section{NATION}

29 SEP 1996 


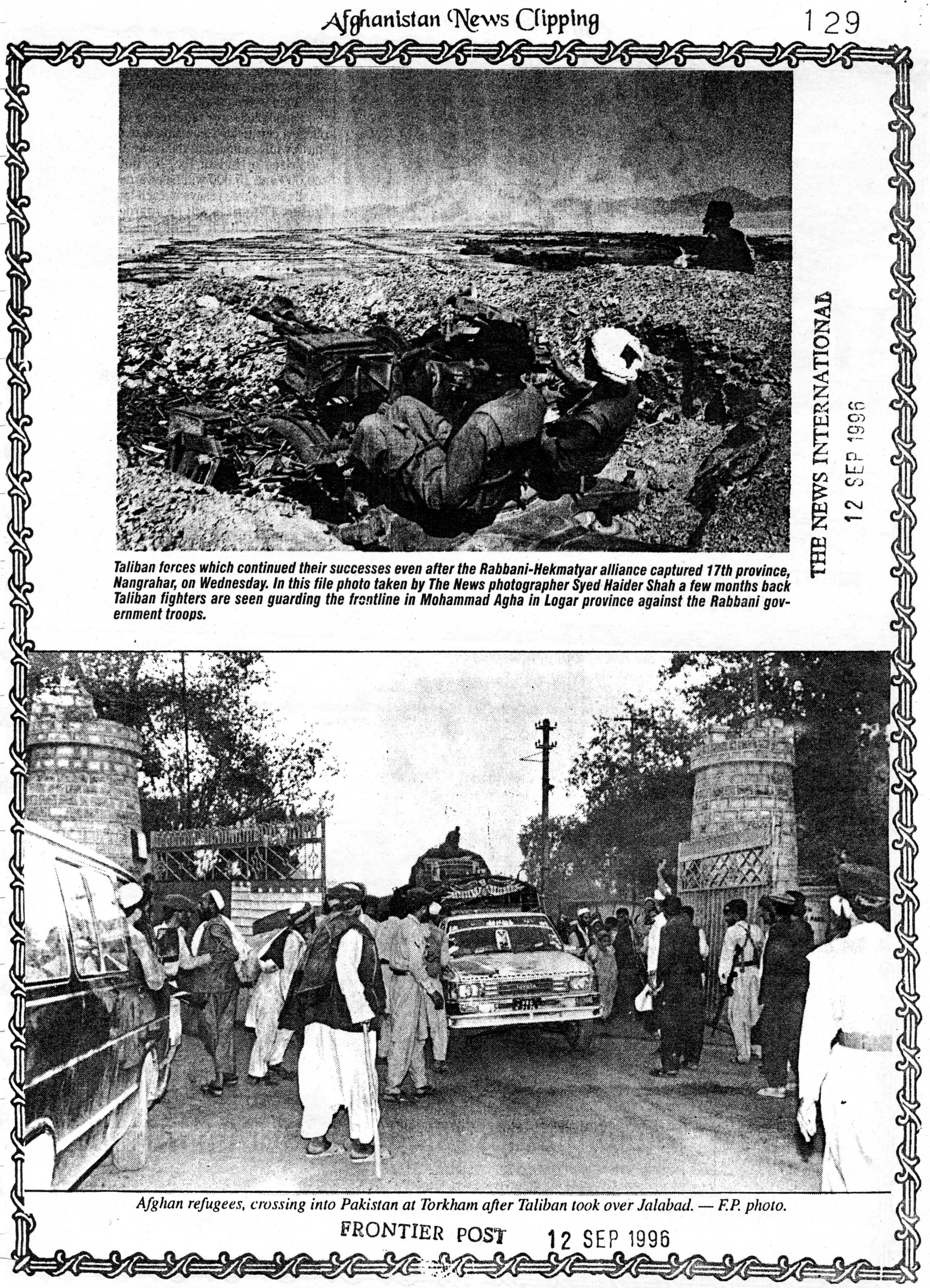




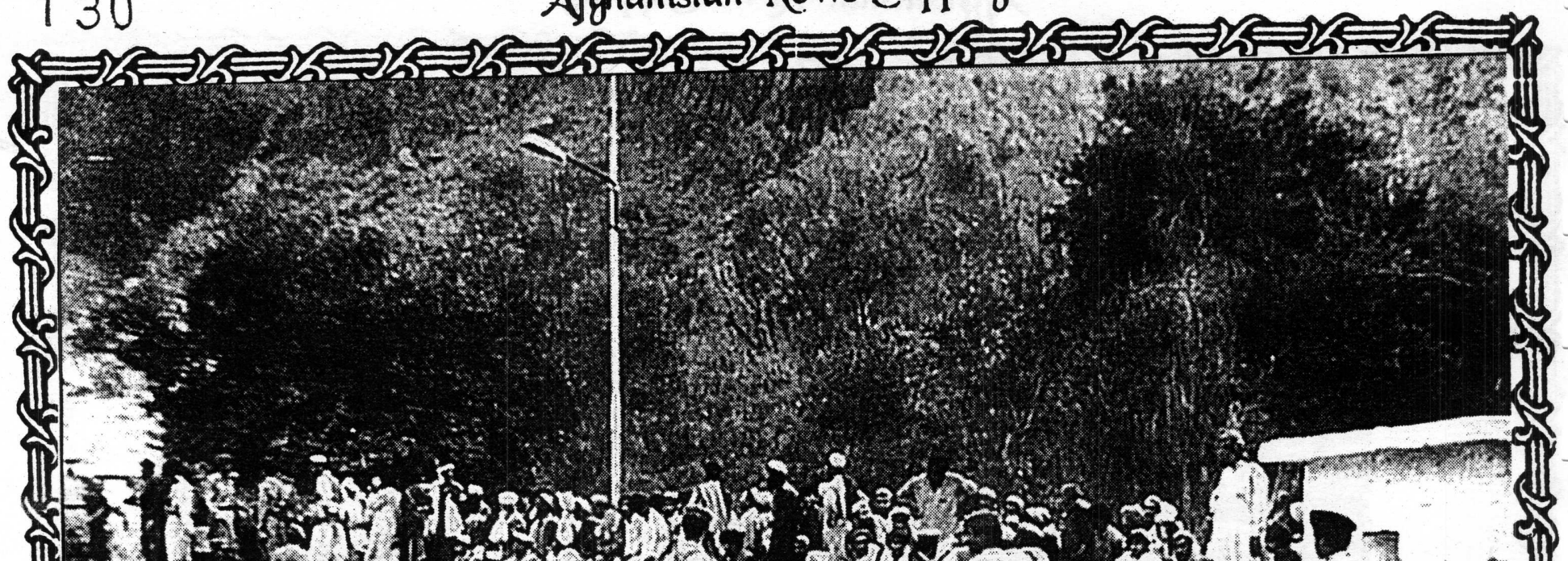

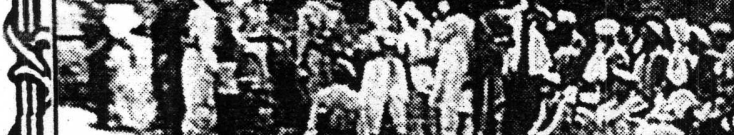

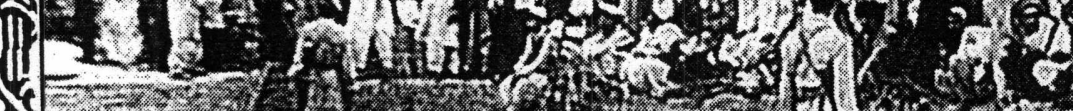

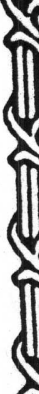

1

BRONTIER POST

12:SEP 1996

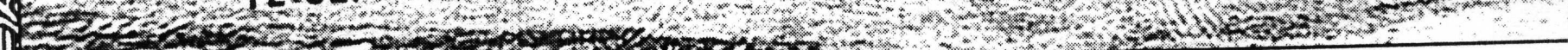

作

WAHEEDULLAH KHAN

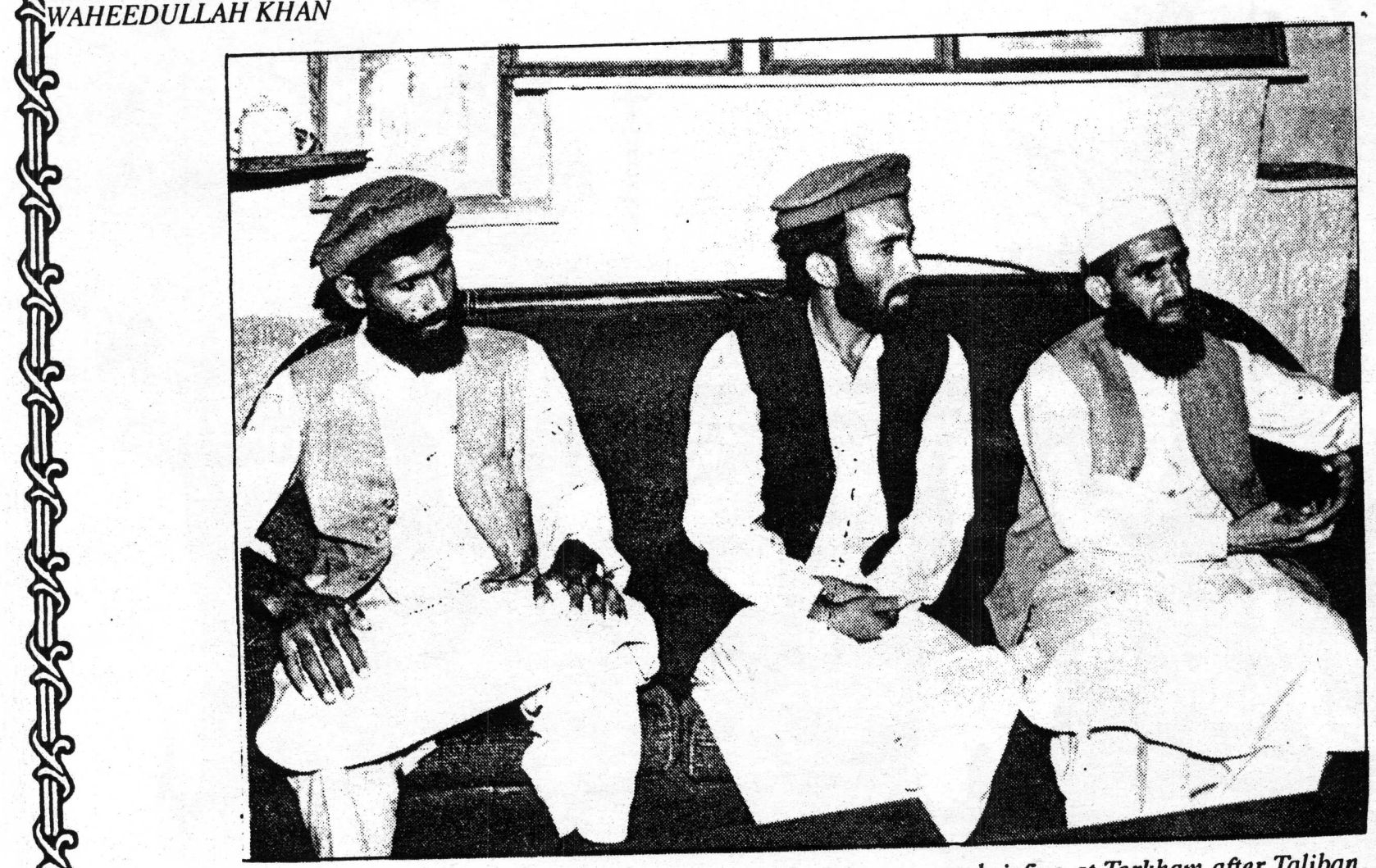

Corps Commander Jalabad, Fazle Haq Mujahid, giving a press briefing at Torkham after Taliban captured Jalabad. - F.P. photo. 


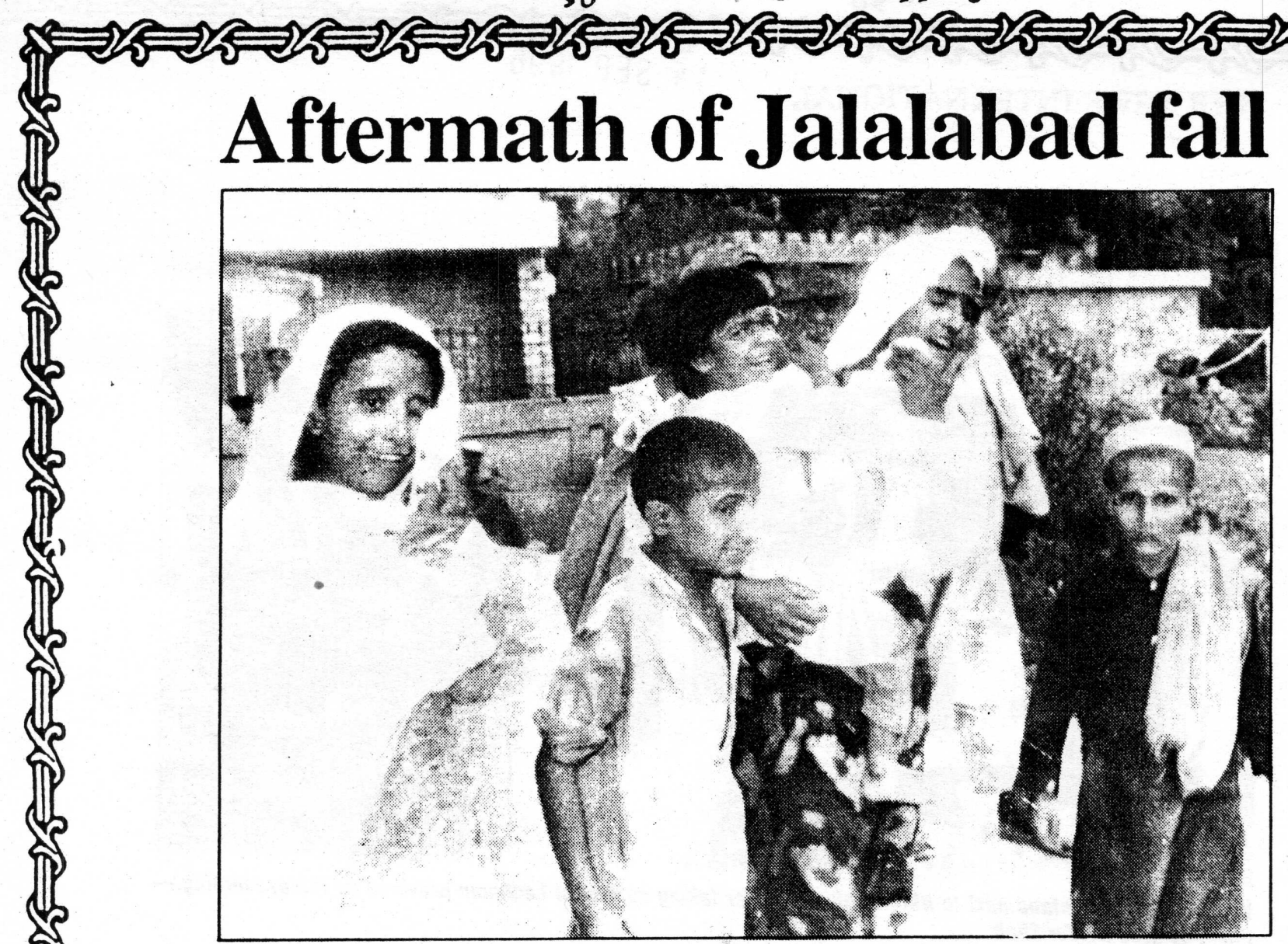

A crying Afghan family crossing the Pak-Afghan border at Torkham after Taliban overrun Jalalabad. - F.P. photo

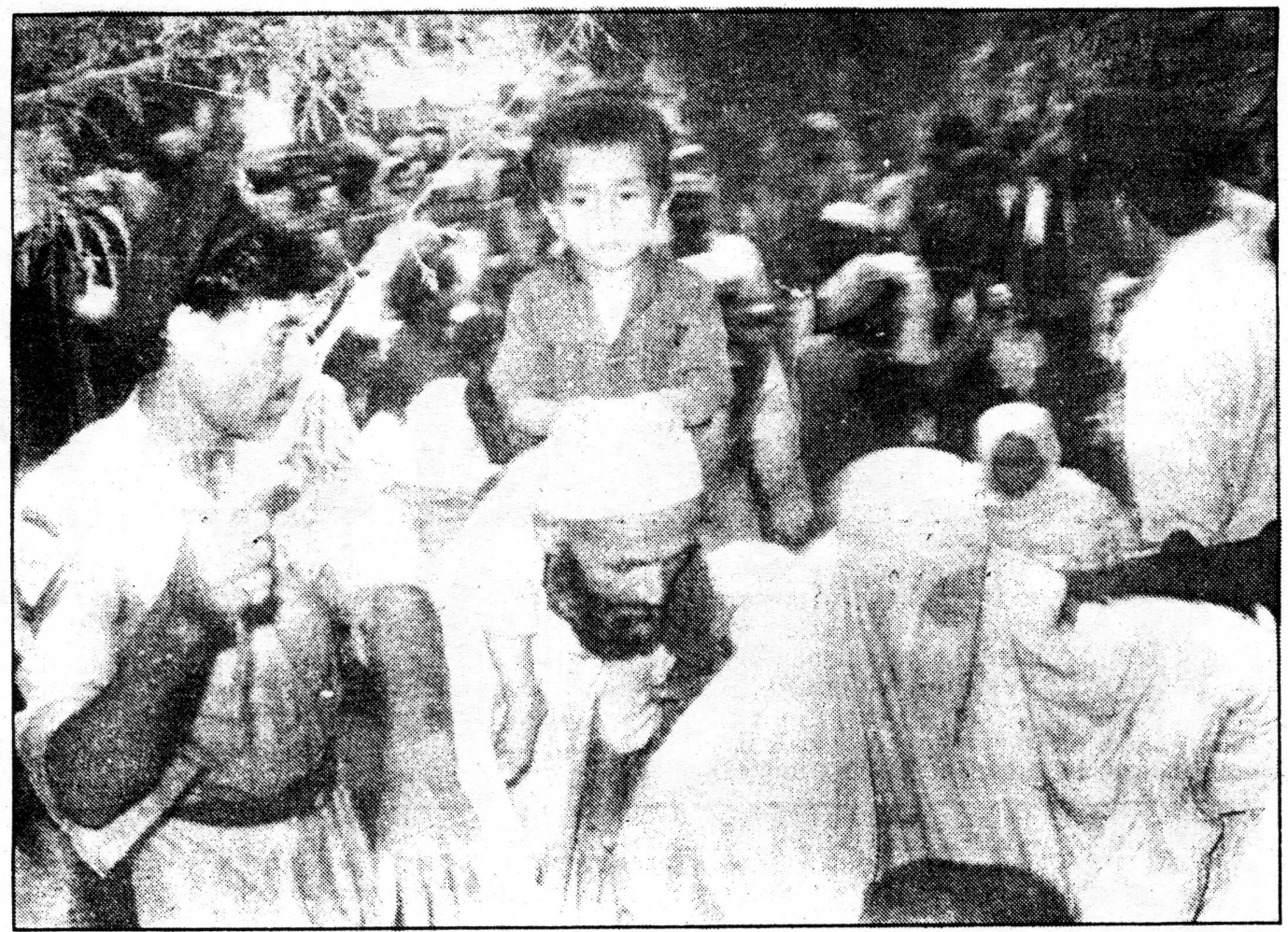

Fleeing Afghans entering into Pakistan via Torkham after Taliban captured Jalalabad. - F.P. photo 


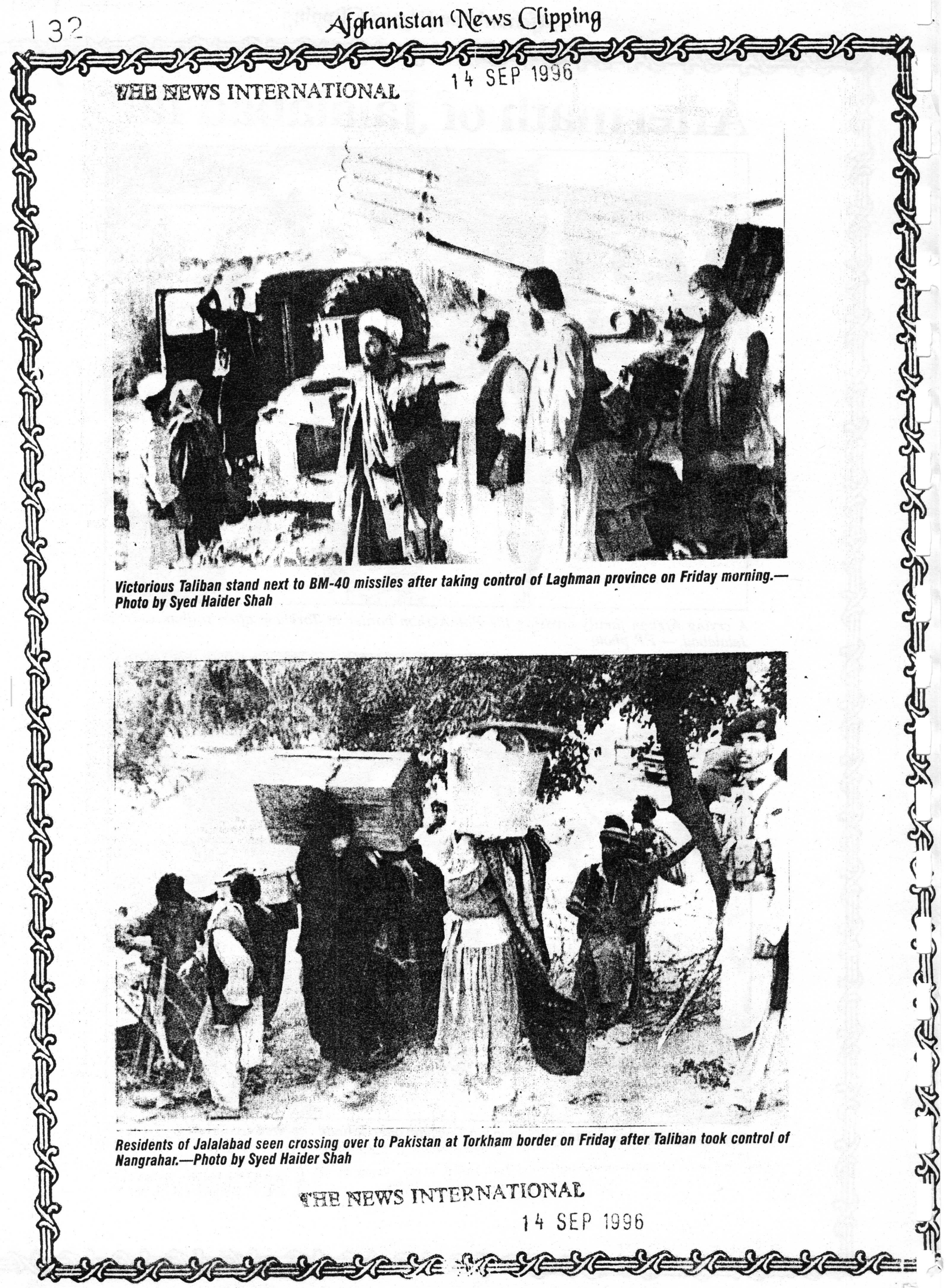




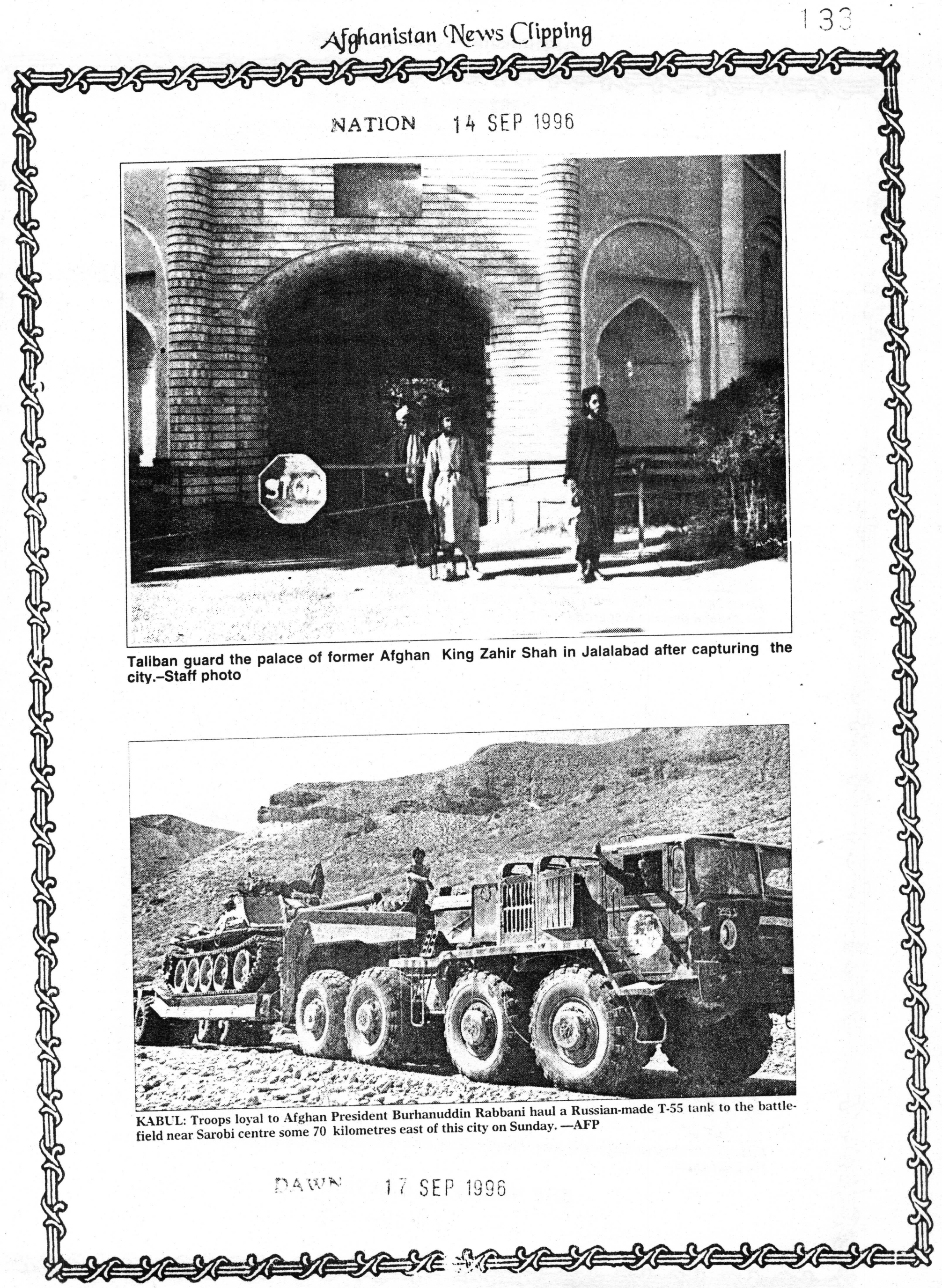




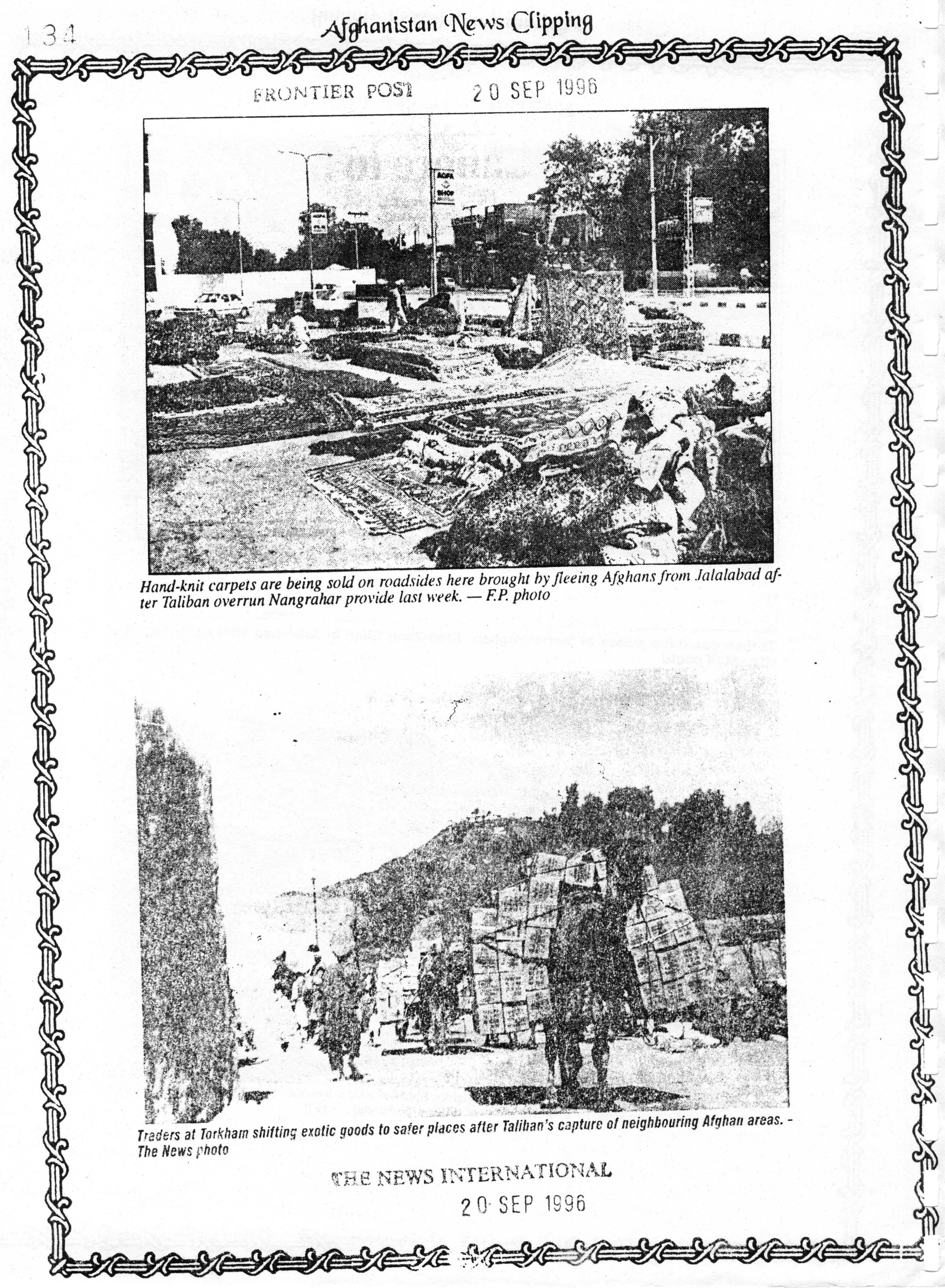




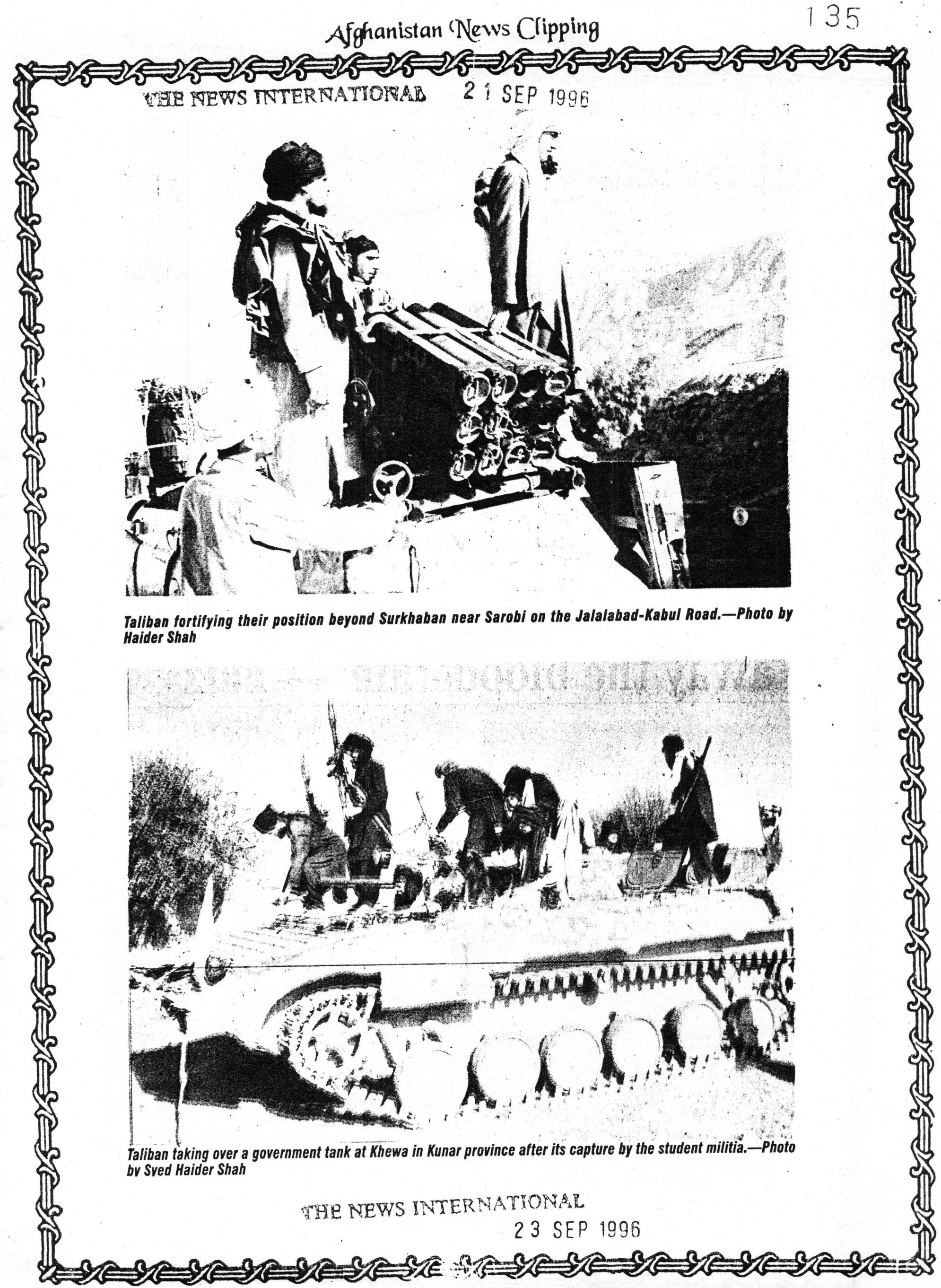




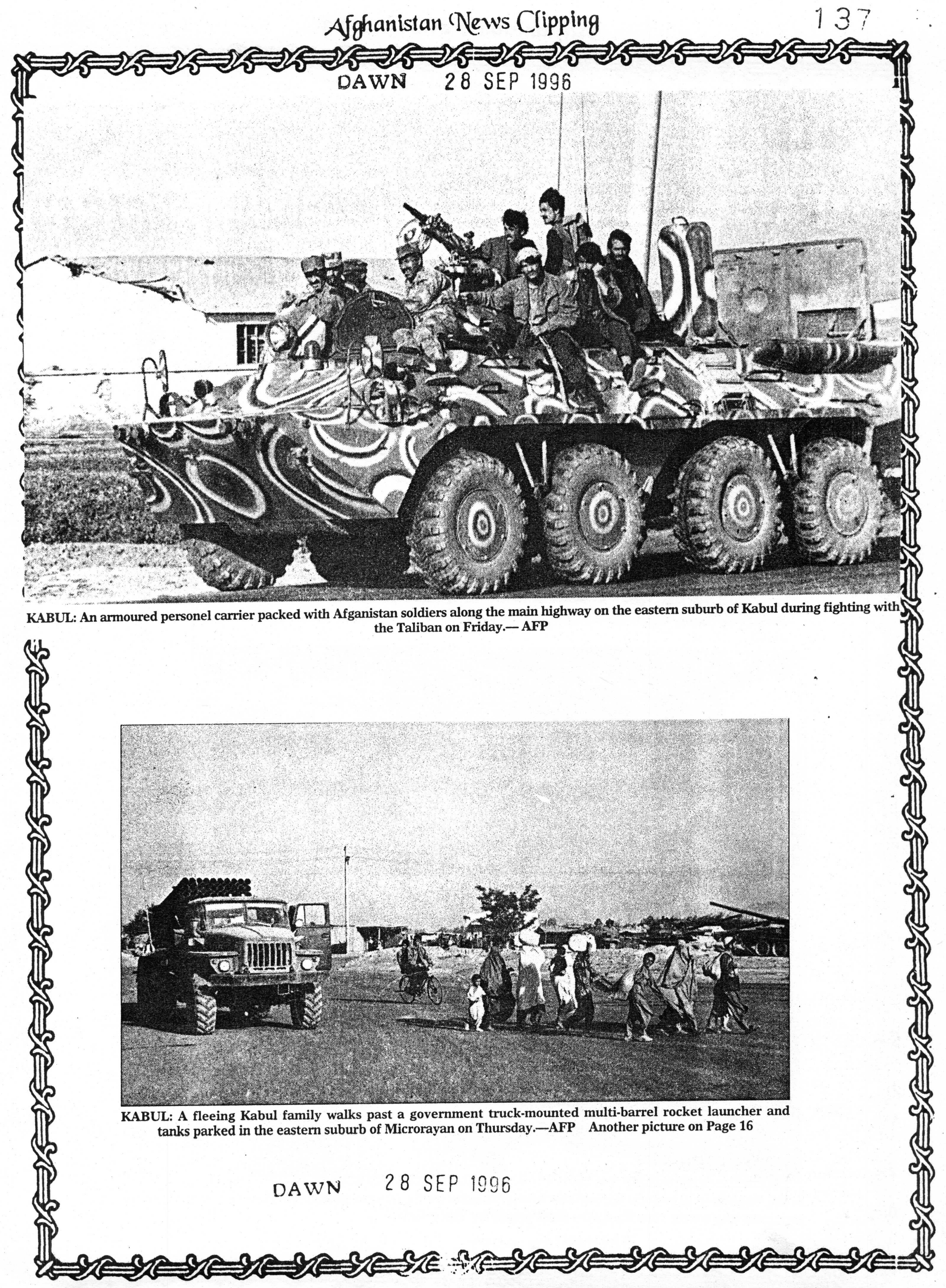




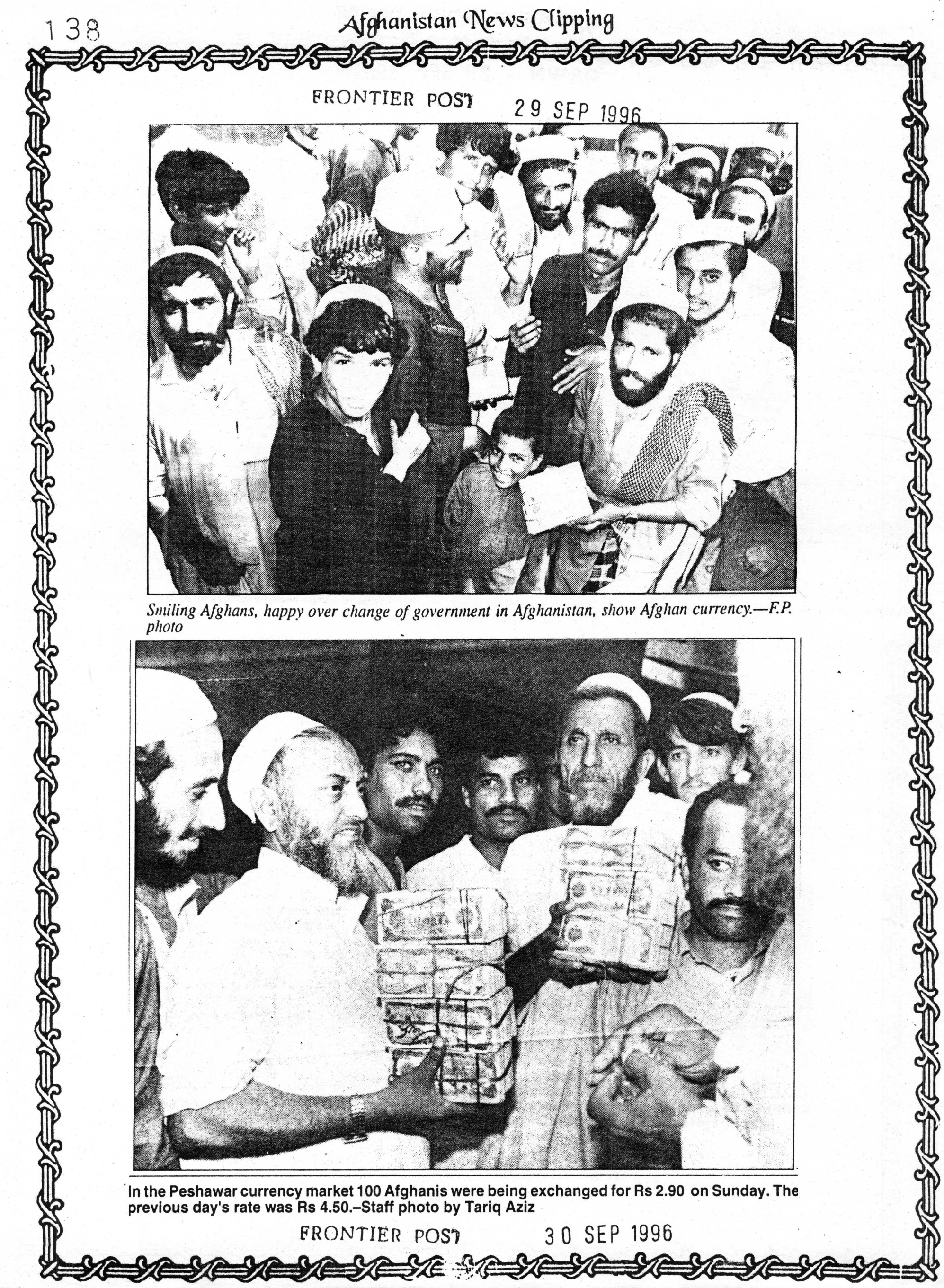




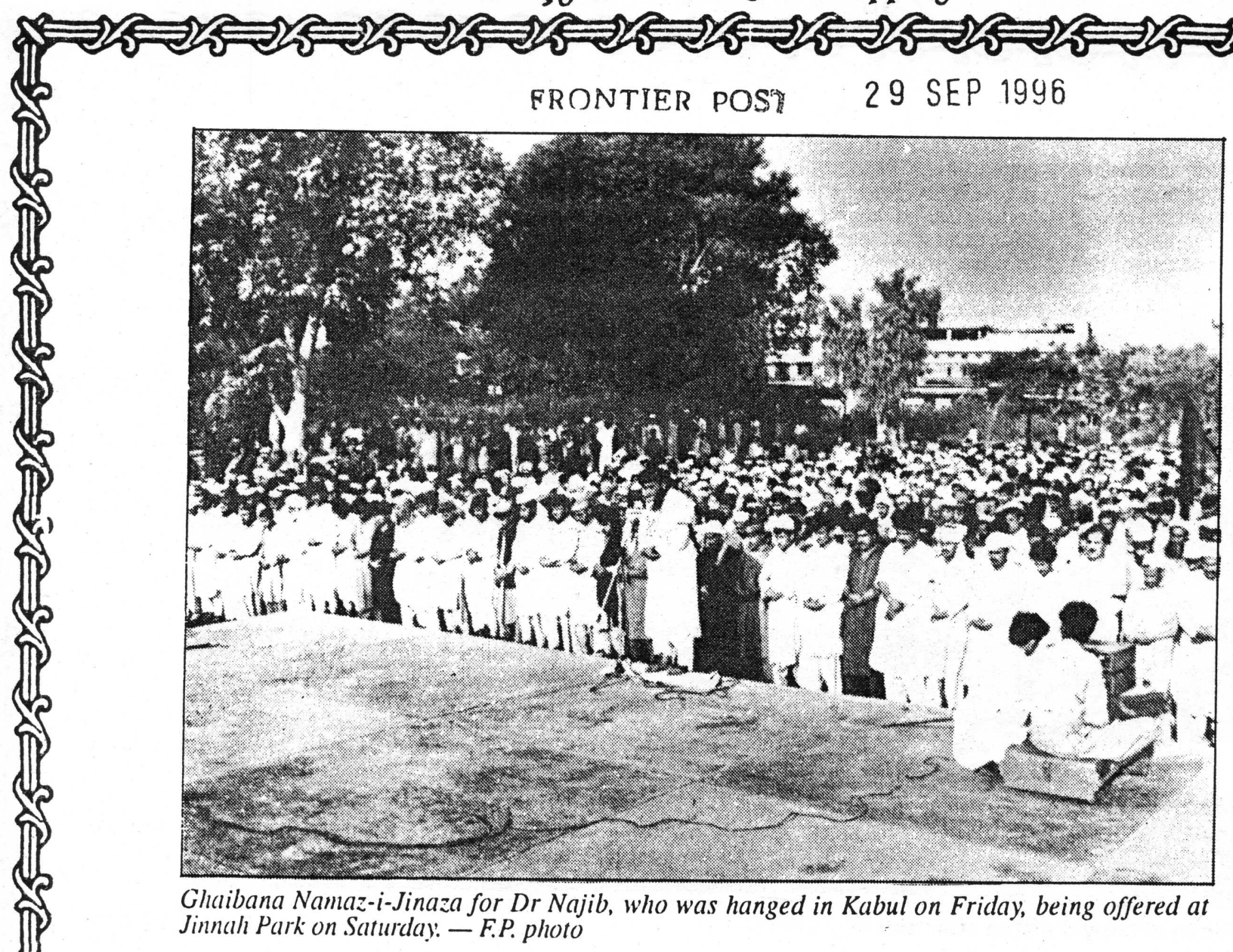

Kabul on Friday, being offered at Jinnah Park on Saturday: - F.P. photo

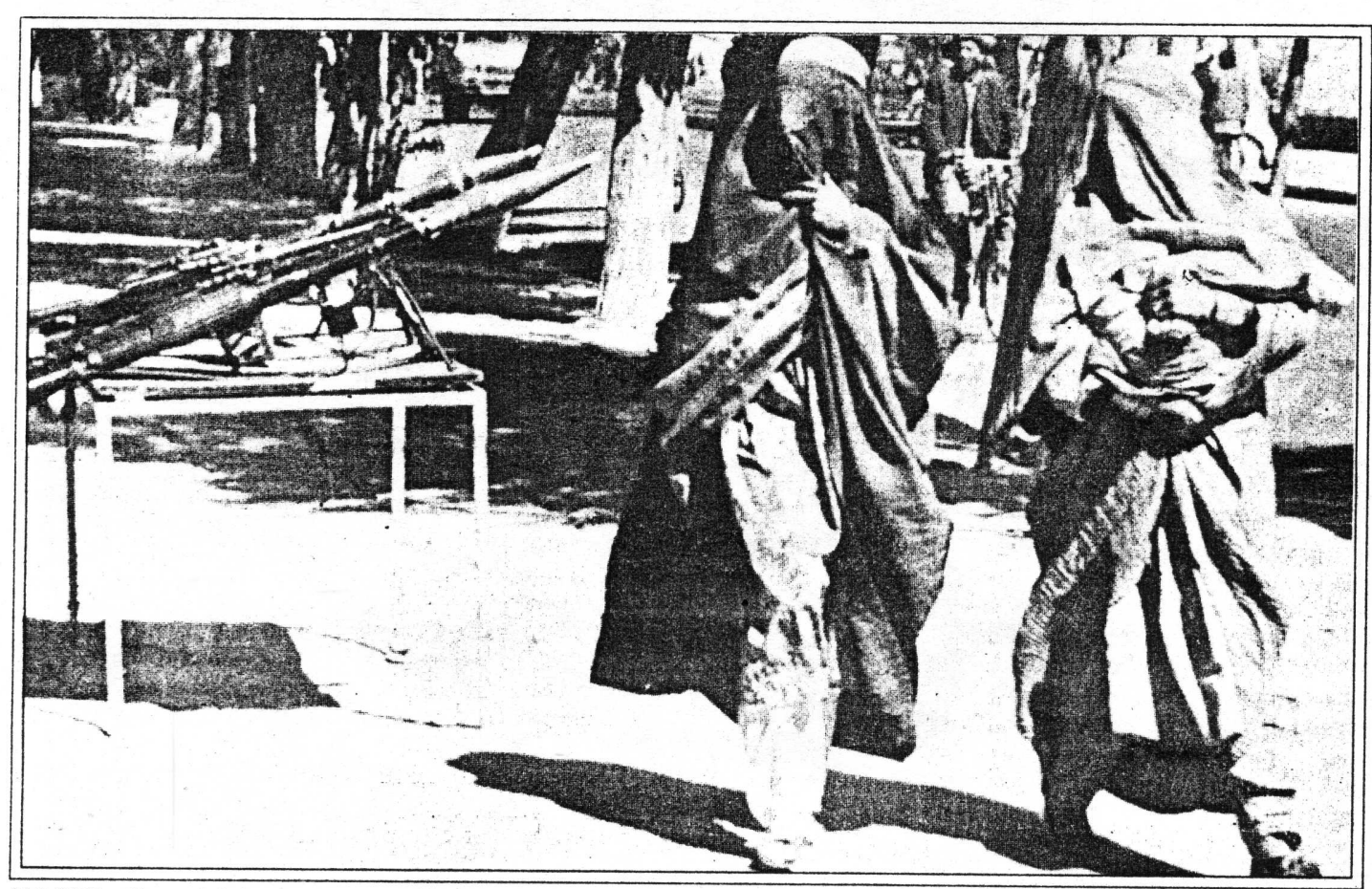

KABUL: Two Afghan women dressed in the full traditional veiled called the "chadari" passes by the weapons of Taliban militia near the Defence Ministry, here. The women has to dress according to the ruling Taliban - AFP. 


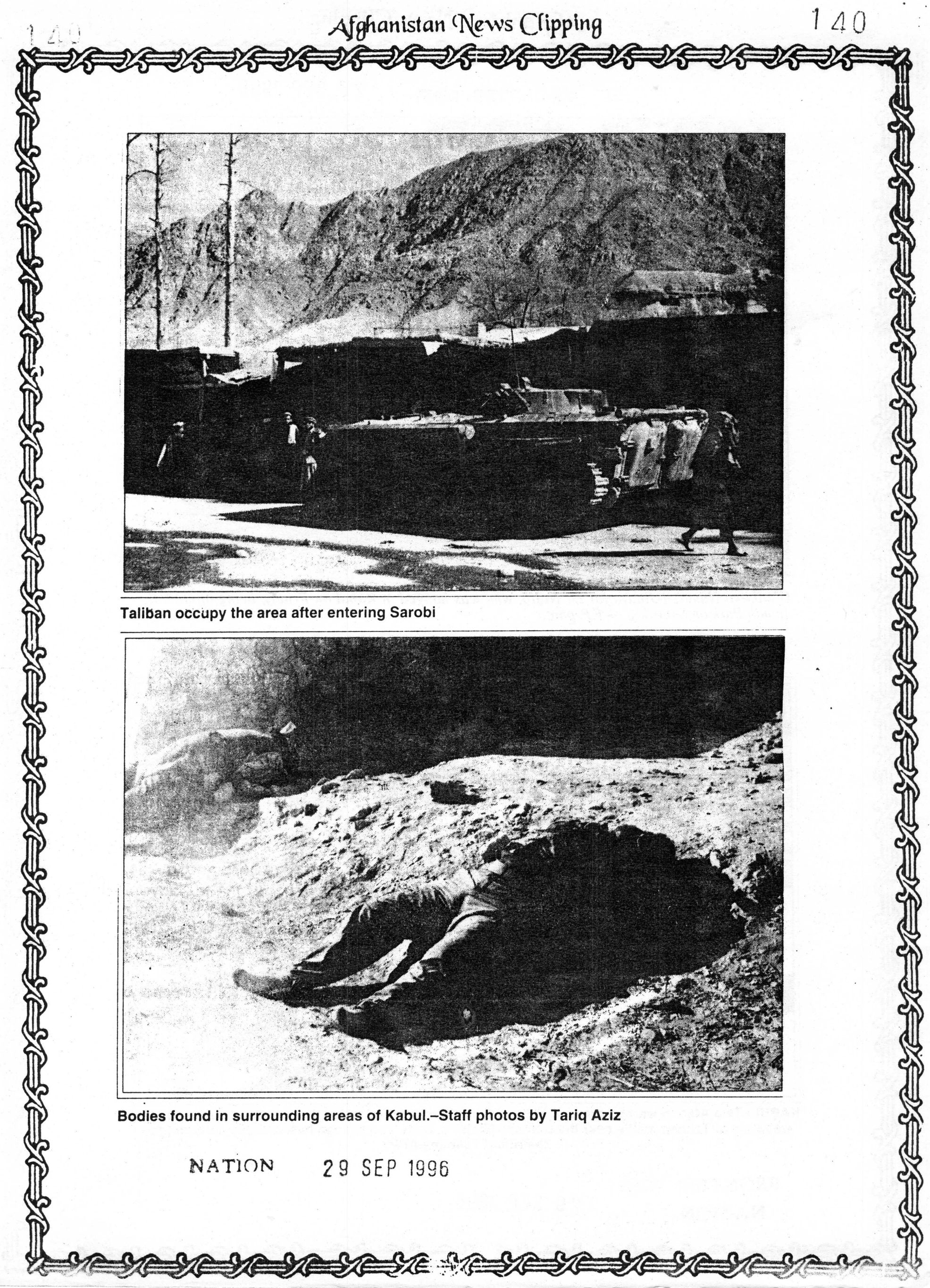




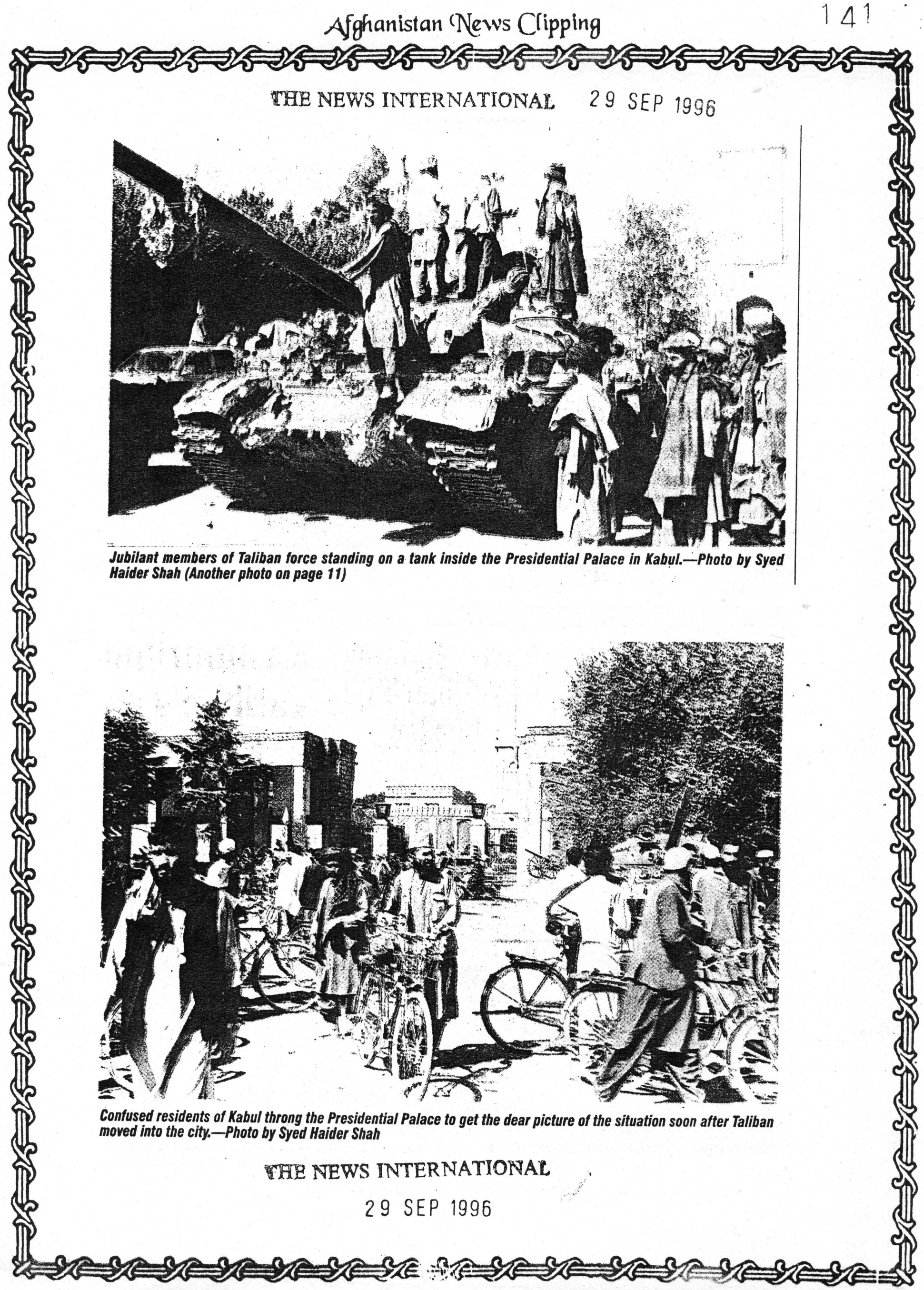




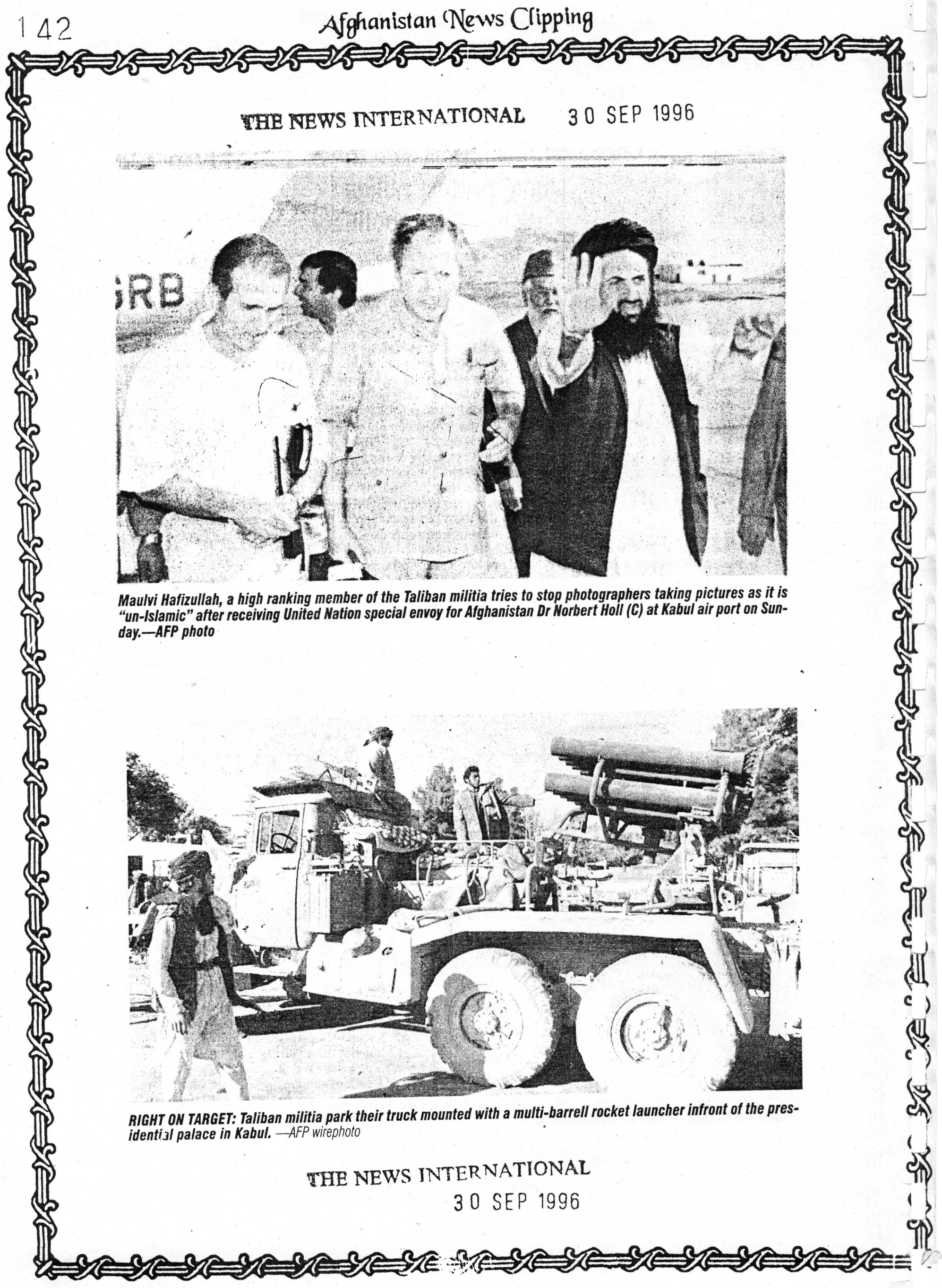




\section{Afghanistan (News Clipping}

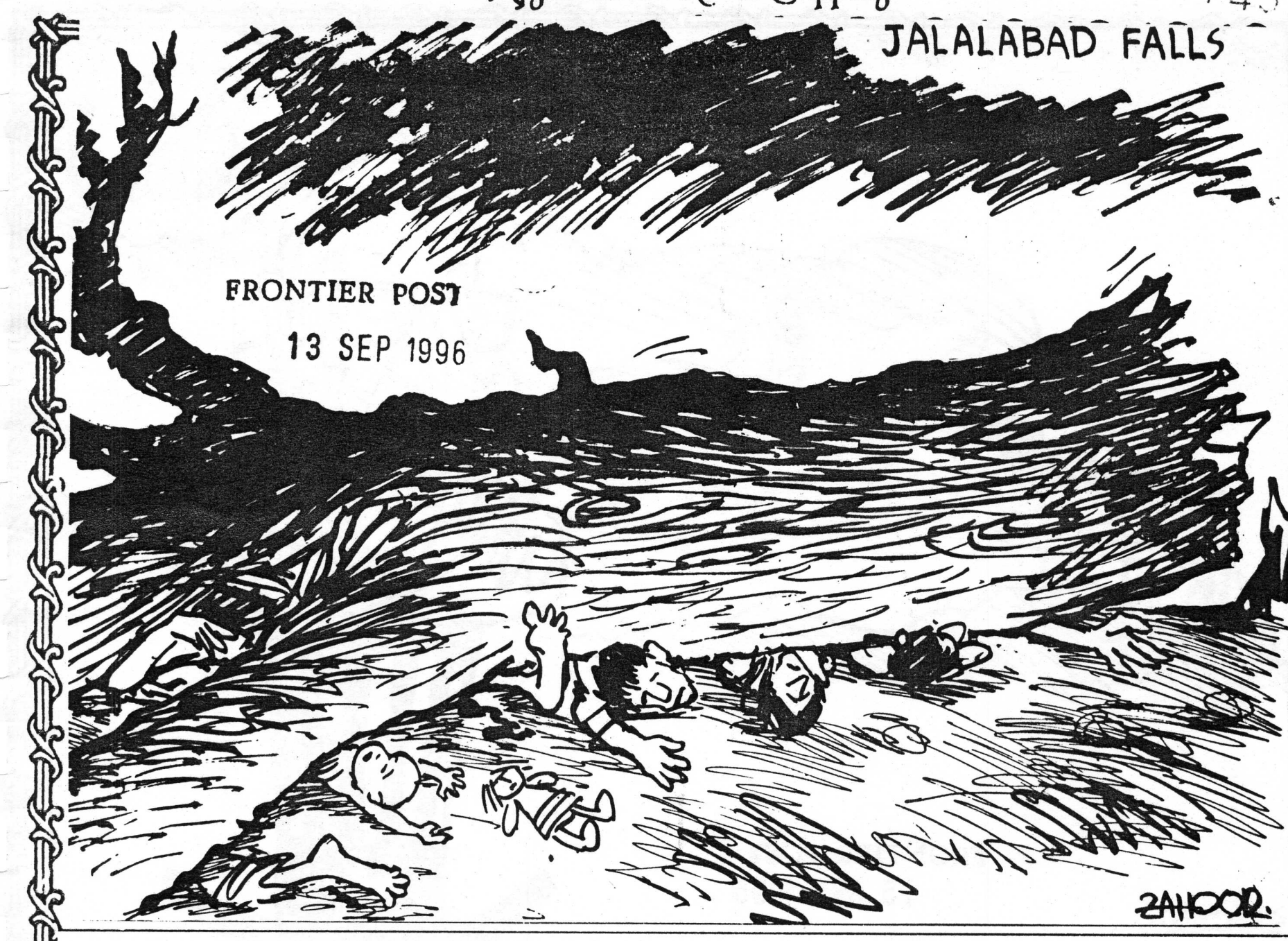

部 
$141 \quad$ Afghanistan News Clipping

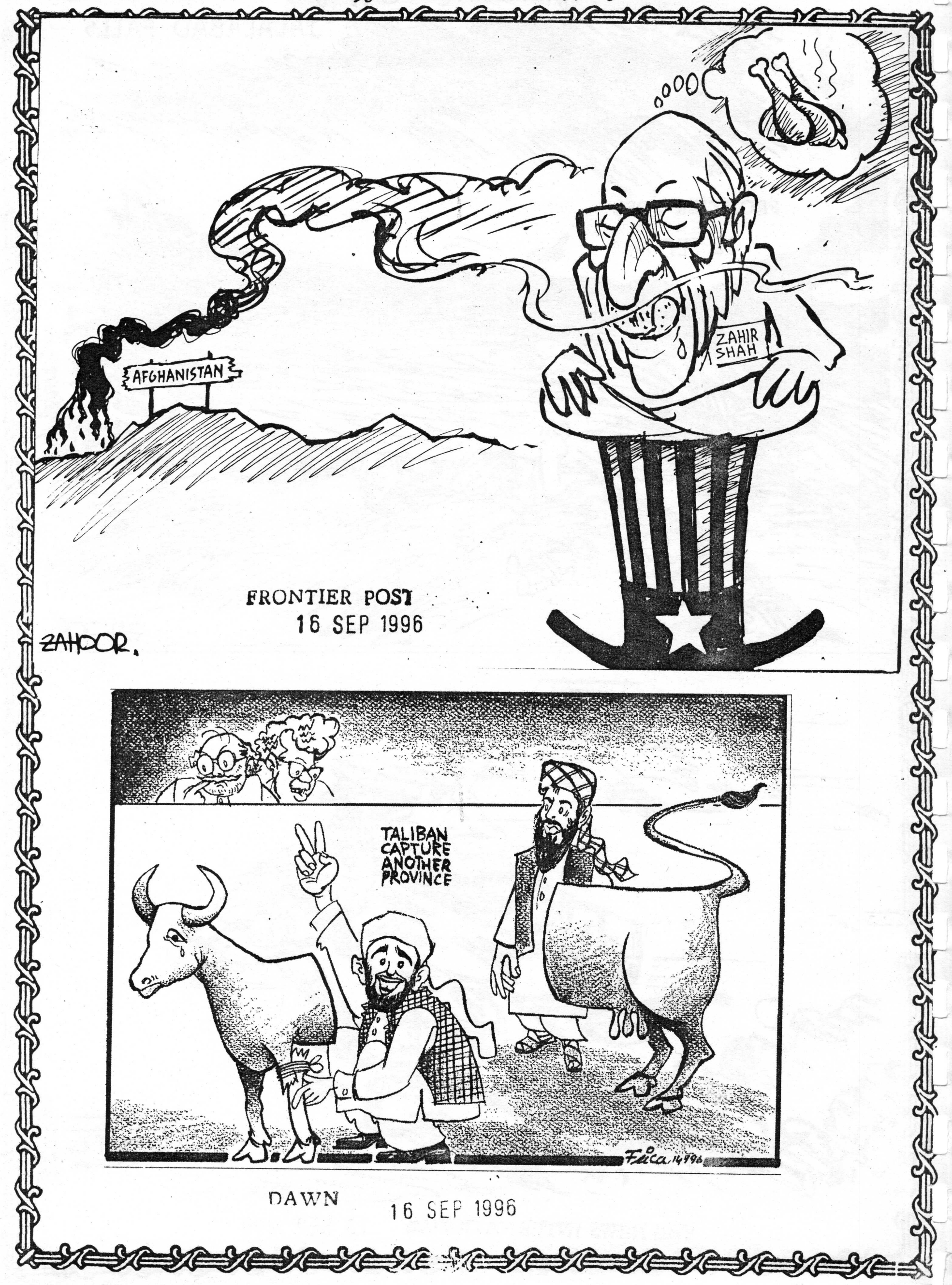




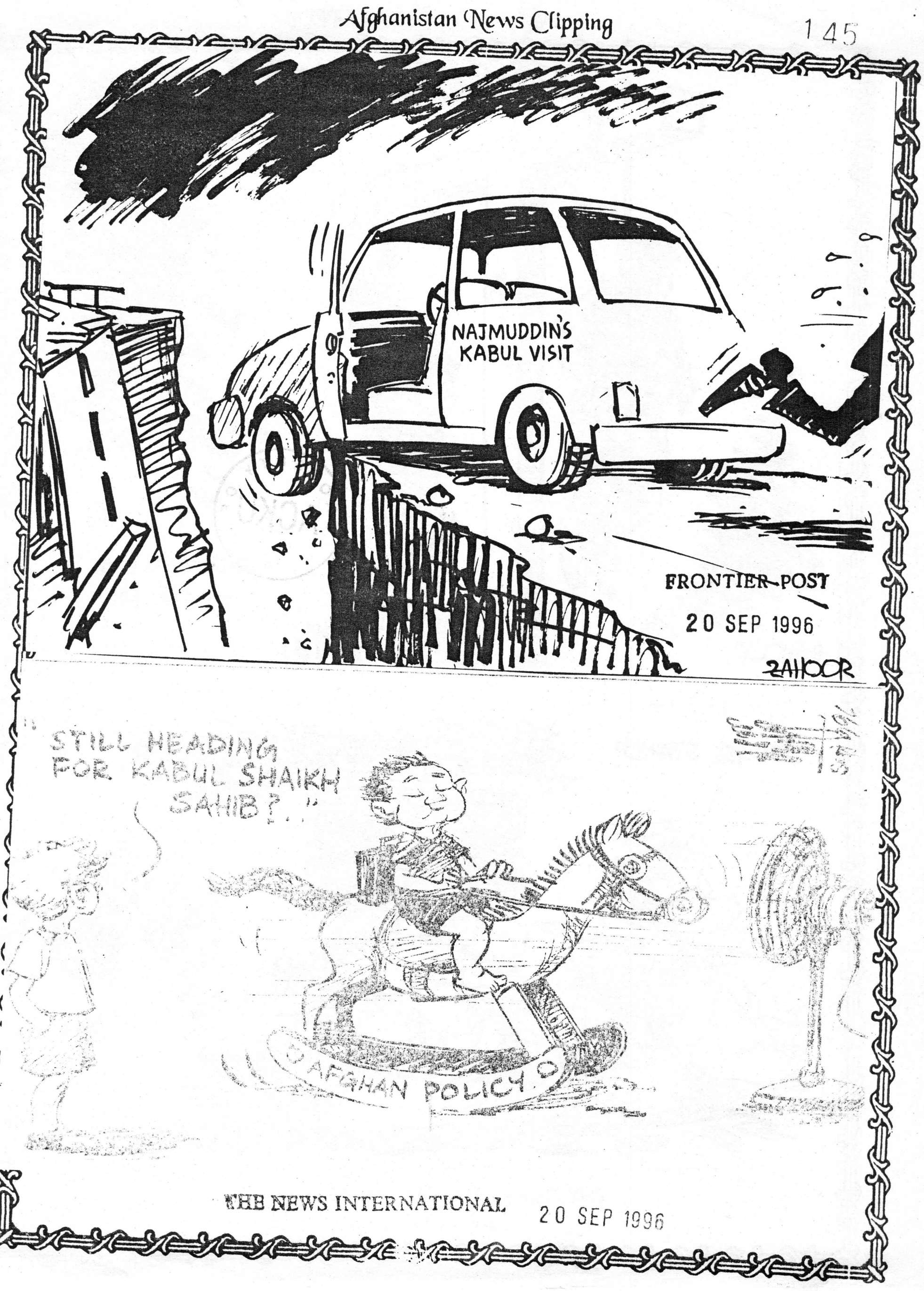


145 Afghanistan (News Clipping

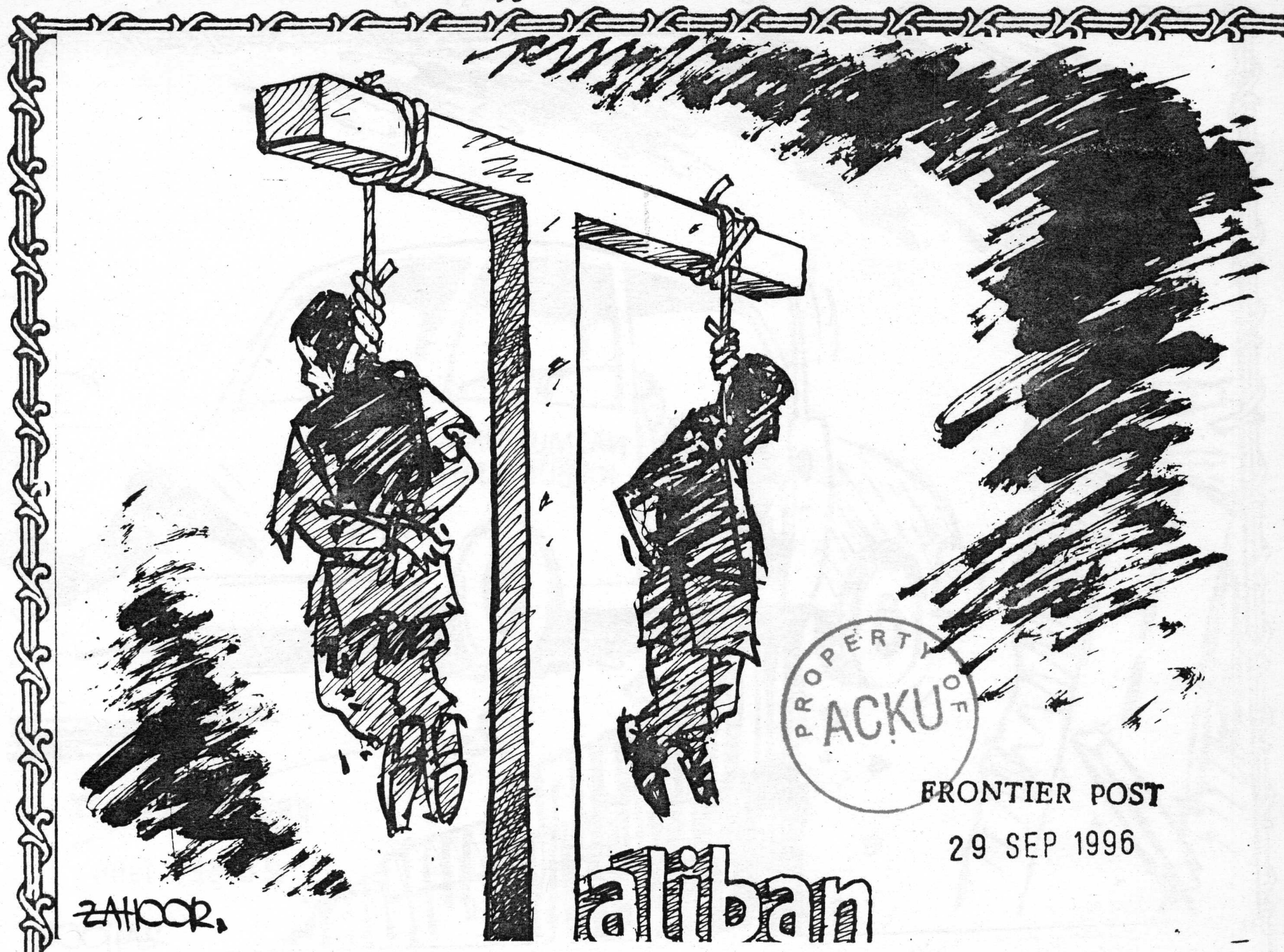

化

䧑

院

ए

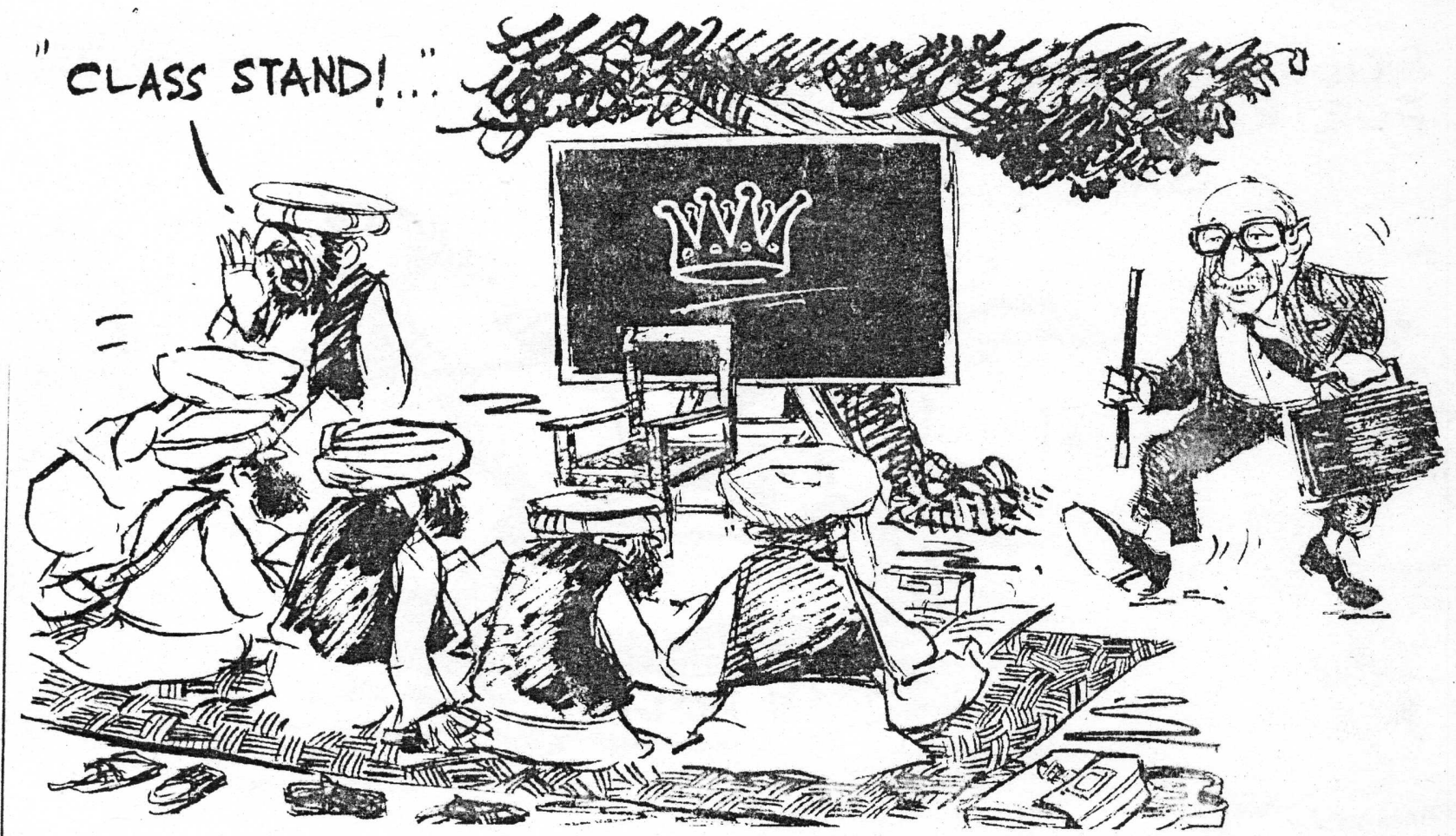

WHE NEWS INTERNATIONAL 